\title{
WestVirginiaUniversity
}

THE RESEARCH REPOSITORY @ WVU

Graduate Theses, Dissertations, and Problem Reports

2015

\section{Evaluation of Roadside Vegetation for Erosion Control in West Virginia}

Eric M. Davis

Follow this and additional works at: https://researchrepository.wvu.edu/etd

\section{Recommended Citation}

Davis, Eric M., "Evaluation of Roadside Vegetation for Erosion Control in West Virginia" (2015). Graduate Theses, Dissertations, and Problem Reports. 5443.

https://researchrepository.wvu.edu/etd/5443

This Thesis is protected by copyright and/or related rights. It has been brought to you by the The Research Repository @ WVU with permission from the rights-holder(s). You are free to use this Thesis in any way that is permitted by the copyright and related rights legislation that applies to your use. For other uses you must obtain permission from the rights-holder(s) directly, unless additional rights are indicated by a Creative Commons license in the record and/ or on the work itself. This Thesis has been accepted for inclusion in WVU Graduate Theses, Dissertations, and Problem Reports collection by an authorized administrator of The Research Repository @ WVU. For more information, please contact researchrepository@mail.wvu.edu. 


\title{
Evaluation of Roadside Vegetation for Erosion Control in West Virginia
}

\section{Eric M. Davis}

\author{
Thesis submitted to the \\ Benjamin M. Statler College of Engineering and Mineral Resources \\ at West Virginia University \\ in partial fulfillment of the requirements for the degree of \\ Master of Science in \\ Civil and Environmental Engineering \\ Dr. Leslie Hopkinson, Ph.D., Chair \\ Dr. Avinash Unnikrishnan, Ph.D. \\ Dr. Yoo Jung Yoon, Ph.D
}

Department of Civil and Environmental Engineering

\author{
Morgantown, West Virginia \\ 2015
}

Keywords: Roadside vegetation, highway construction reclamation, erosion control, ground cover 


\section{Abstract \\ Evaluation of Roadside Vegetation for Erosion Control in West Virginia}

\section{Eric M. Davis}

The West Virginia Division of Highways (WVDOH) utilizes the establishment of grass as a temporary and permanent management practice to mediate the effects of erosion on highway construction sites. The disturbed conditions of reclaimed slopes often present challenges for vegetation establishment and long-term cover. Seventy percent cover of vegetation by area is desired. This research evaluated the effectiveness of the current reclamation practices at right of way locations. The status of vegetation cover was considered to identify site factors that contributed to low and high ground cover along roadsides and medians. Thirty-three roadside and median study sites incorporated variability in soil type, elevation, vegetation establishment and cover, seed mixture, slope, aspect, time since planting, and climate. Vegetation cover was measured, and species distribution was identified. Slopes, aspects of the sloping face, and elevations were recorded. Soil samples were tested for nutrients, minerals, texture, and $\mathrm{pH}$. Approximately $50 \%$ of the test sites met the $70 \%$ cover criteria. Locations of the worst cover $(<50 \%)$ had soils with high soluble salt content $(0.36-1.54 \mathrm{mmhos} / \mathrm{cm})$ or low organic matter values $(<2 \%)$. Vegetation cover was dominated by tall fescue (Festuca arundinacea) and crownvetch (Coronilla varia $L$.), two species that were included in the current seeding mixture and are considered invasive. To further promote revegetation success and persistence, both maintenance and site specific seed mixtures are needed. 


\section{Acknowledgements}

It is with great pleasure that I would like to thank all of the people who committed their time and effort in completing this research project. In particular, special thanks go to Dr. Leslie Hopkinson. Her continued support and guidance from undergraduate studies into graduate studies are truly appreciated. I also want to thank Dr. Hopkinson for serving as committee chairperson, academic advisor, and mentor throughout this project. Without her guidance, knowledge, and motivation it would not have been possible to complete this project.

I would also like to specially thank George Hilvers for his efforts in the field data collection of the project as well as his continued support and assistance with all tasks involved with the project. Charlie Riling, Donny Williams, Michael Pumphrey from the WVDOH are truly thanked for their assistance in experimental site locations and their continued efforts and assistance through the duration of the project. I would also like to mention and thank Joseph Cottrill, Adam Strong, and Joanna Graham for their assistance in the collection of field data and data entry. Finally, I would like to thank Dr. Avinash Unnikrishnan and Dr. Yoo Jung Yoon for serving as committee members.

In addition to my colleagues, I would like to thank my parents, Michael and Mona Davis. Their love and constant support were a daily motivation. I also thank my brother Brandon Davis. His commitment to this great nation and unwavering friendship provided consistent motivation to reach my goals. Lastly and most importantly, I want to thank my wife Kara Davis. She has been the rock behind me for many years. Her constant motivation and love cannot be thanked enough. Without her, I could not have accomplished the achievements that I have. Without the support and motivation of these individuals, this research would not have been possible. 


\section{Grant Information}

The contents of this report reflect the views of the author who is responsible for the facts and the accuracy of the data presented herein. The contents do not necessarily reflect the official views or policies of the State. This report does not constitute a standard, specification, or regulation. Trade or manufacturers' names which may appear herein are cited only because they are considered essential to the objectives of this report. The State of West Virginia does not endorse products or manufacturers. Prepared for the West Virginia Department of Transportation Division of Highways. 
Table of Contents

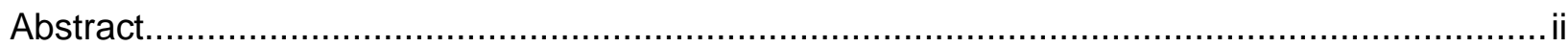

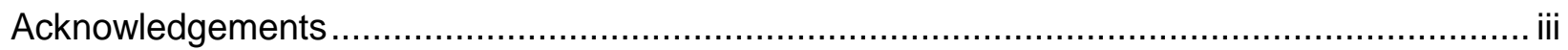

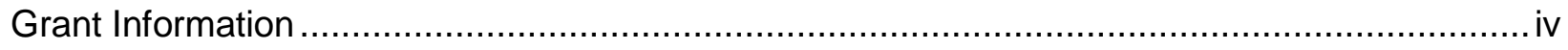

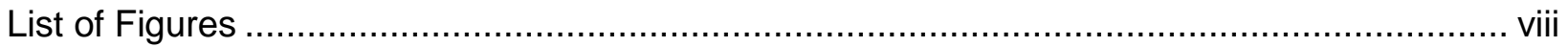

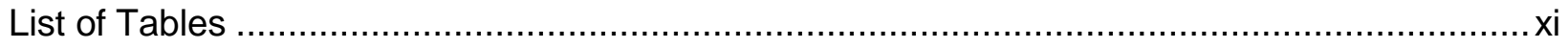

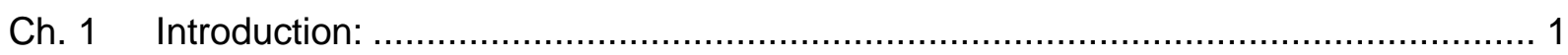

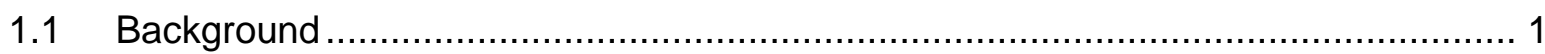

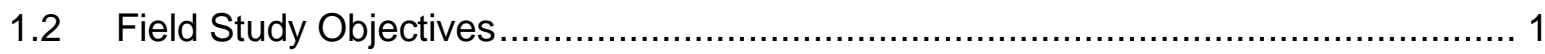

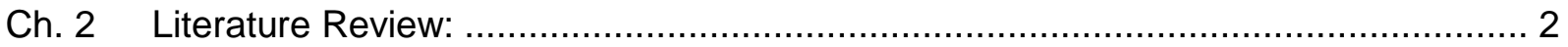

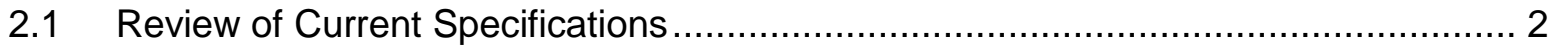

2.1.1 West Virginia Division of Highways (WVDOH) ....................................... 2

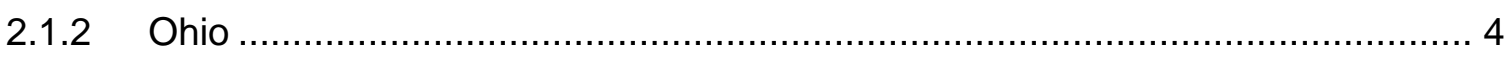

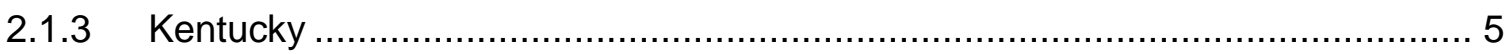

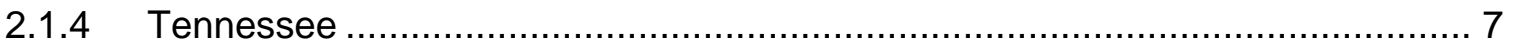

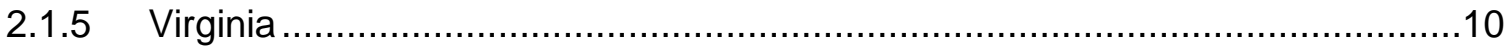

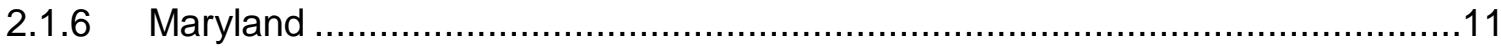

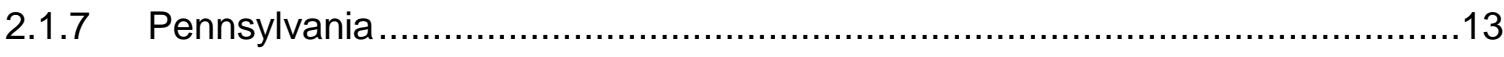

2.1.8 North Carolina ................................................................................... 14

2.1.9 South Carolina ................................................................................. 15

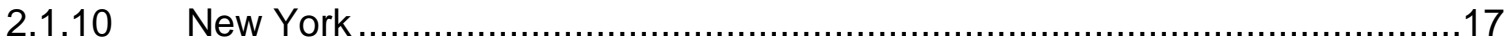

2.1.11 West Virginia Department of Environmental Protection (WVDEP) ................18

2.2 Comparing WV 652 and WVDEP Specifications:.........................................19

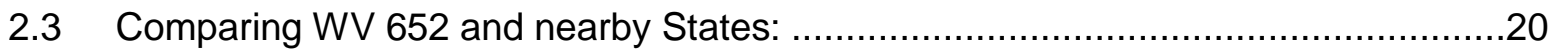

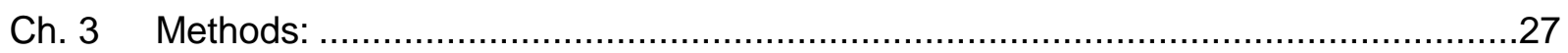

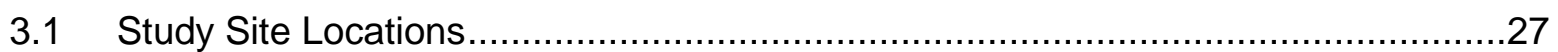

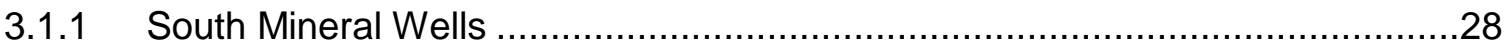

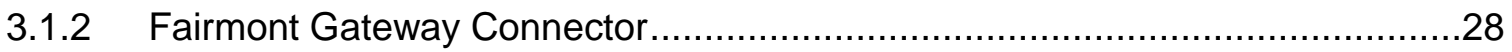

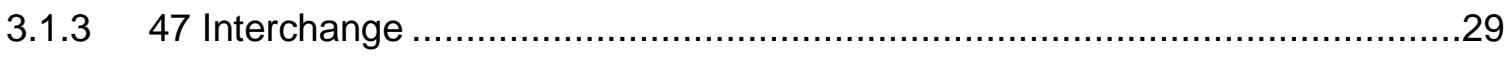

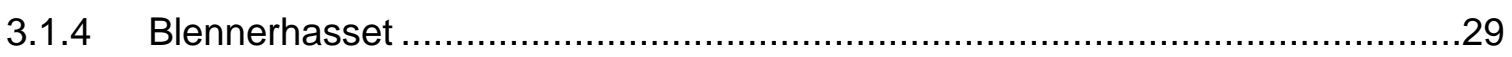

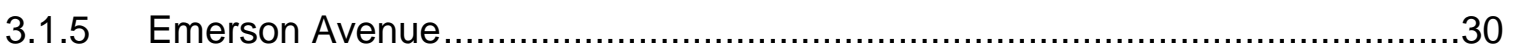

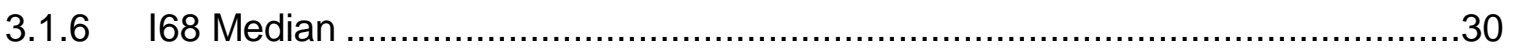

3.1.7 I68 West Virginia Visitor Center..................................................................

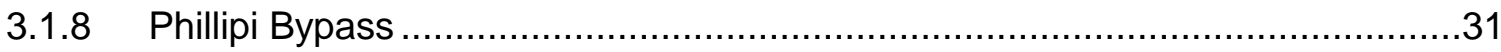

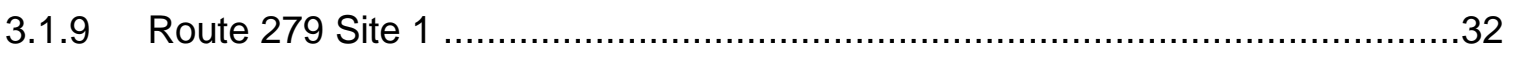




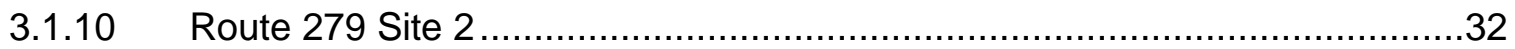

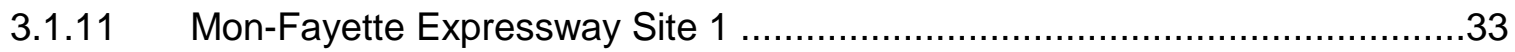

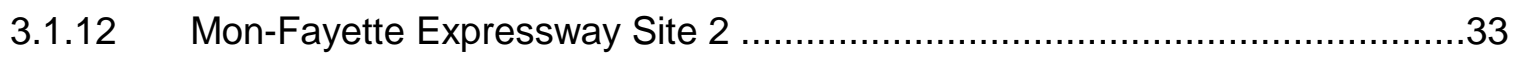

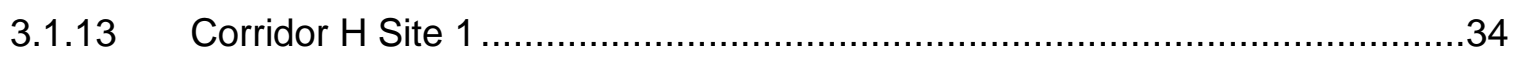

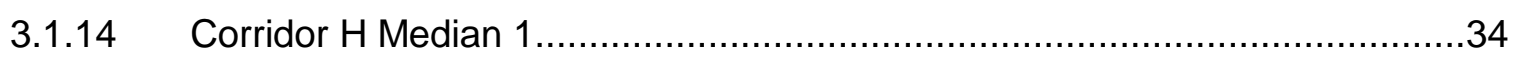

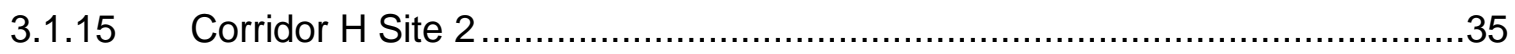

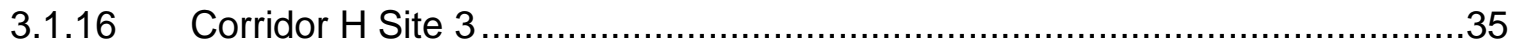

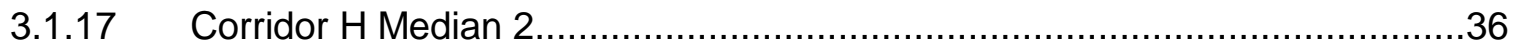

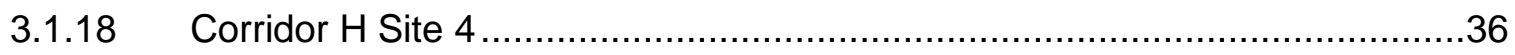

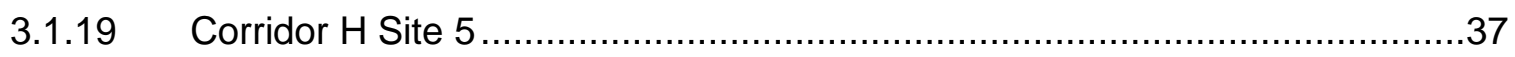

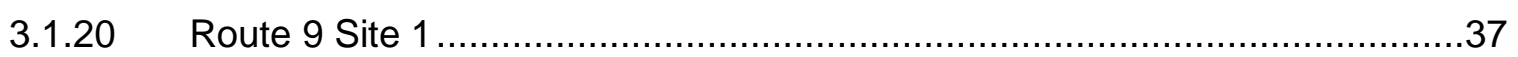

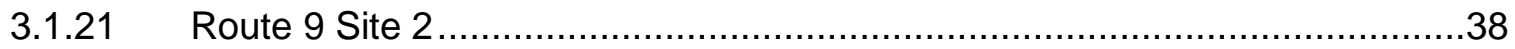

3.1.22 Route 193

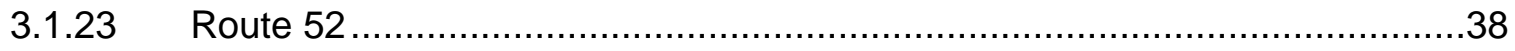

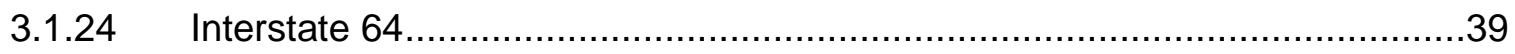

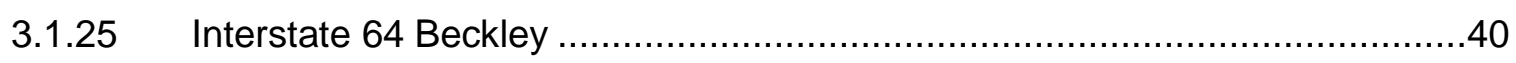

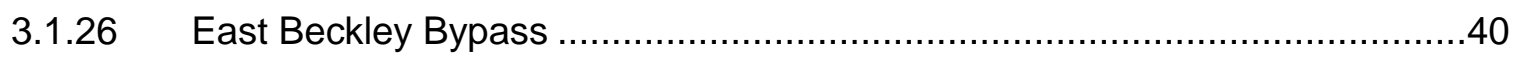

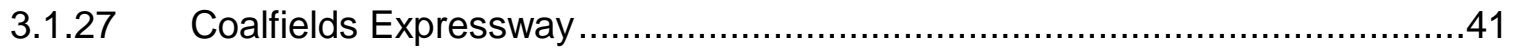

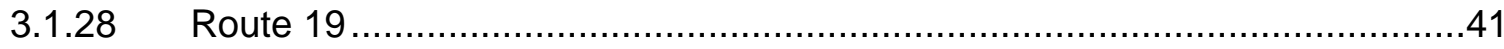

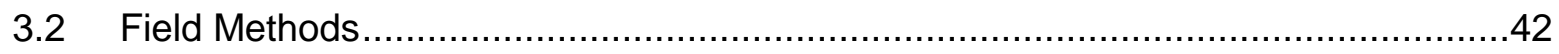

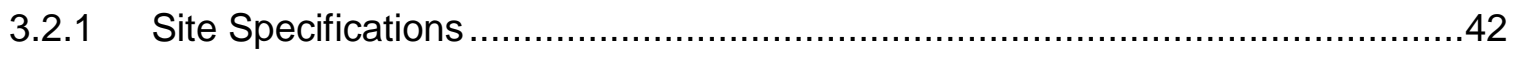

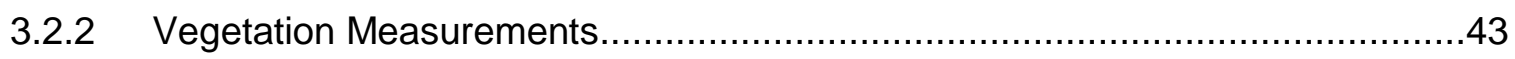

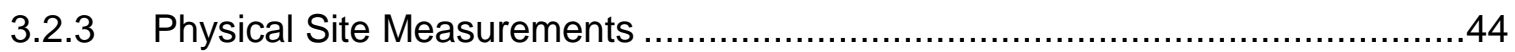

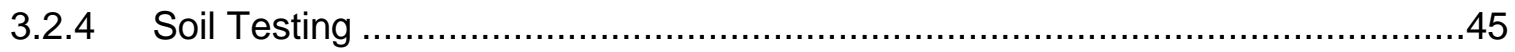

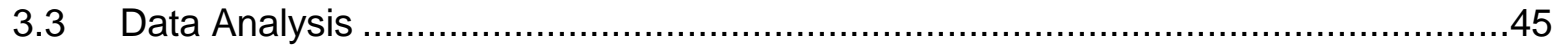

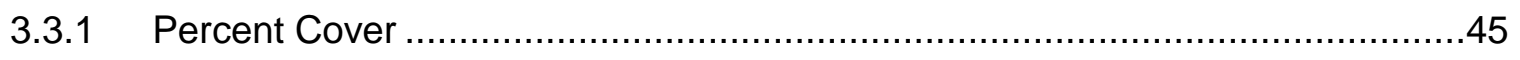

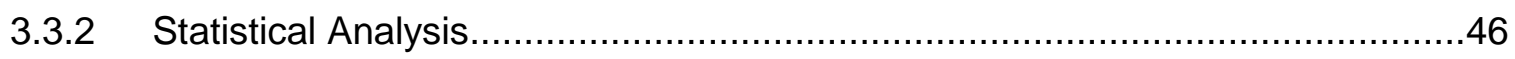

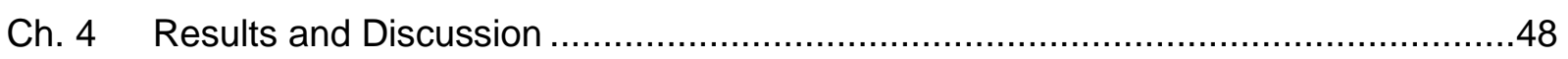

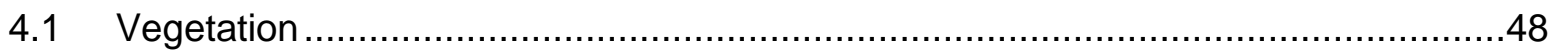

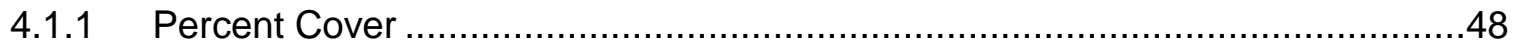

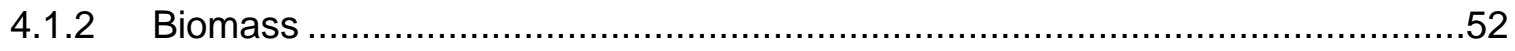

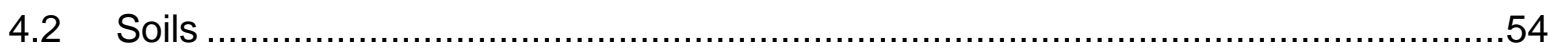

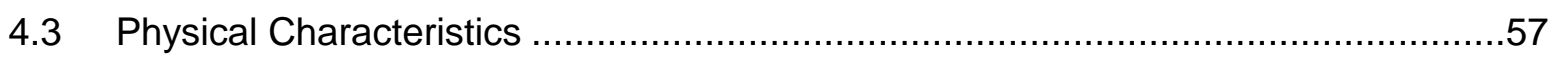

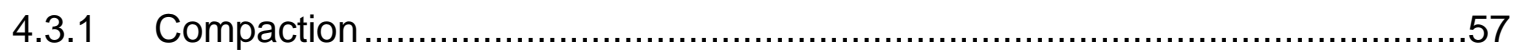

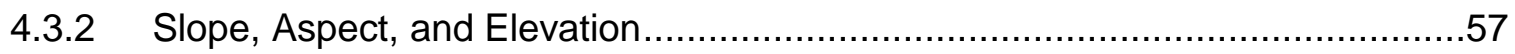

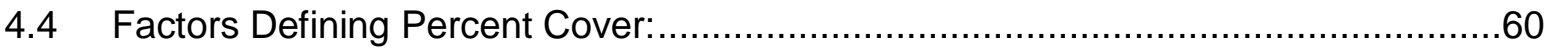




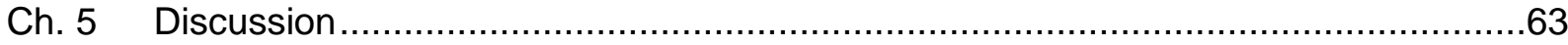

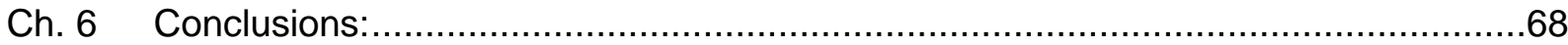

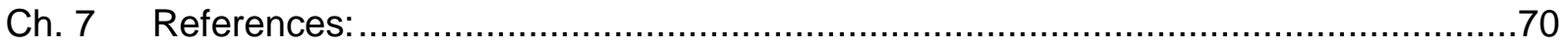

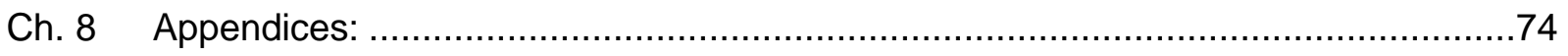

8.1 Appendix A: Observed Vegetation....................................................... 74

8.2 Appendix B: Field Work and Equipment Photos ...........................................78

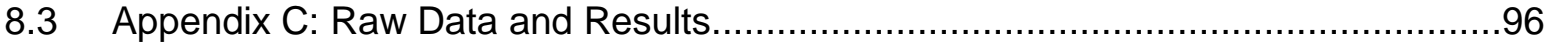

8.4 Appendix D: Field Work Forms ....................................................................... 
List of Figures

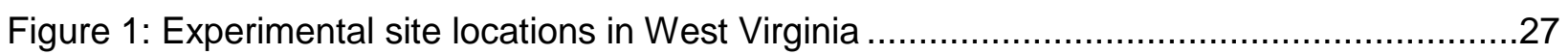

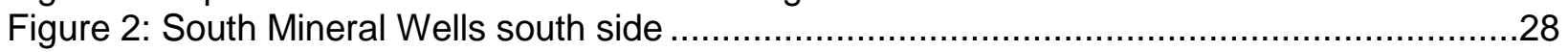

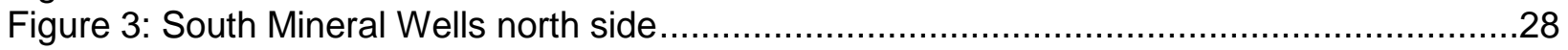

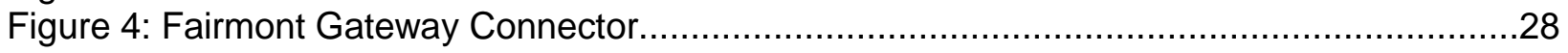

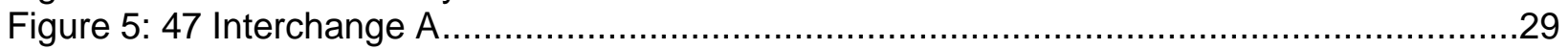

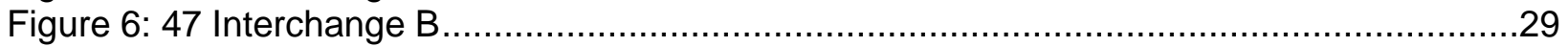

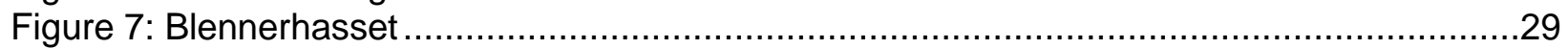

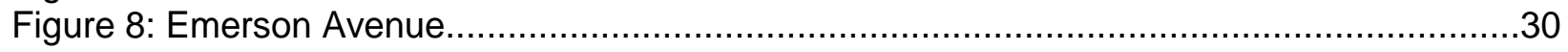

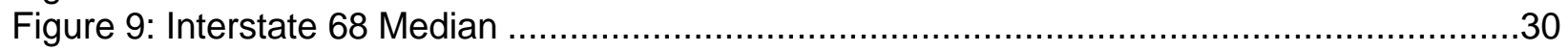

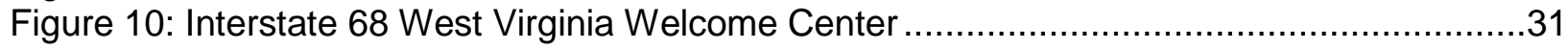

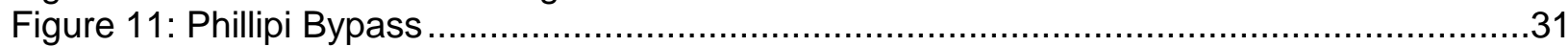

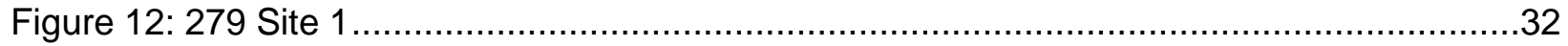

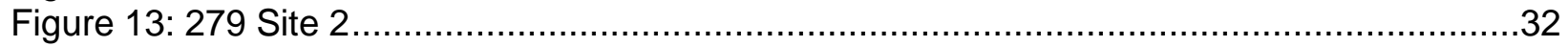

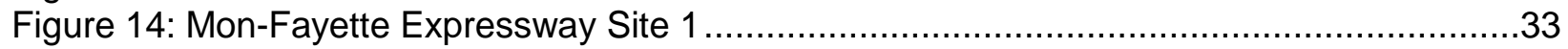

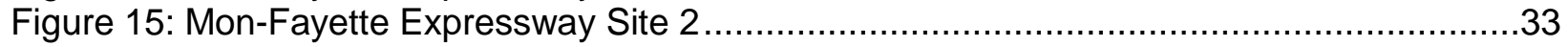

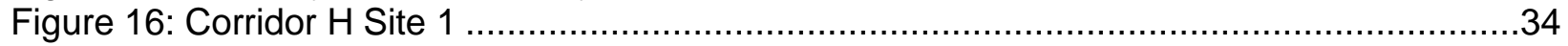

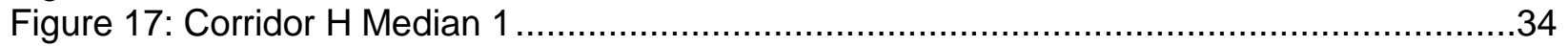

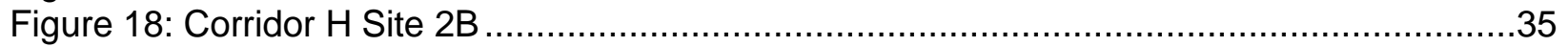

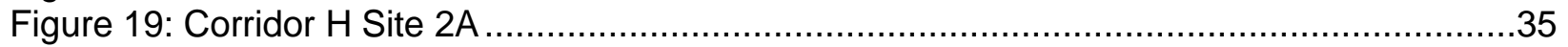

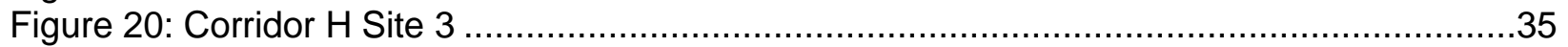

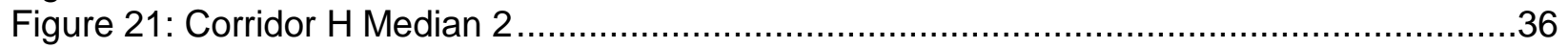

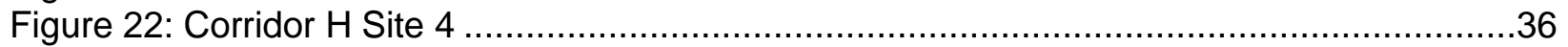

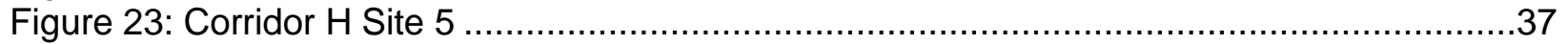

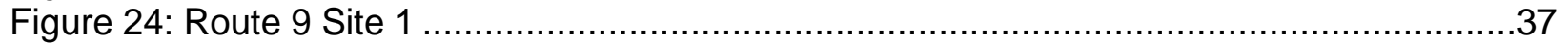

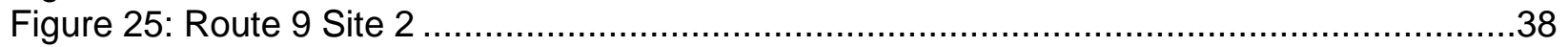

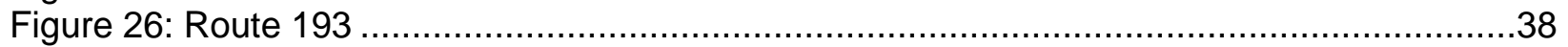

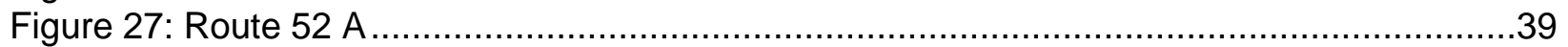

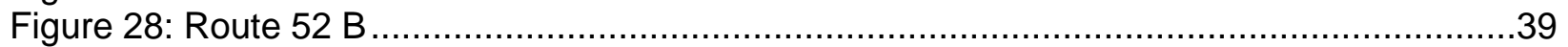

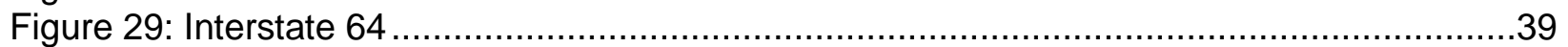

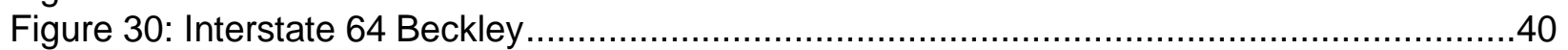

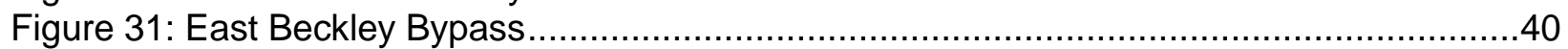

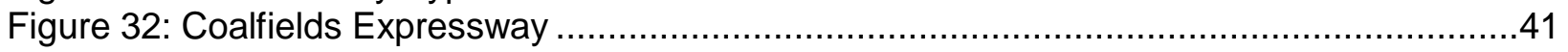

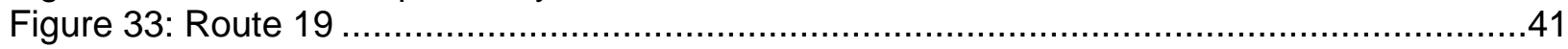

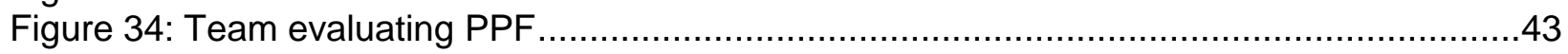

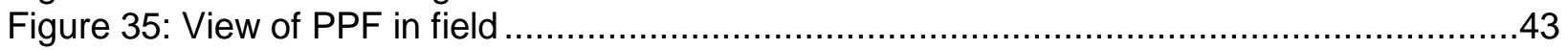

Figure 36: Mean vegetation cover defining cover class (I-IV) for each field site. Error bars denote standard deviation. I (0-50\%), II (50-70\%), III (70-90\%), IV (90-100\%); *indicates a

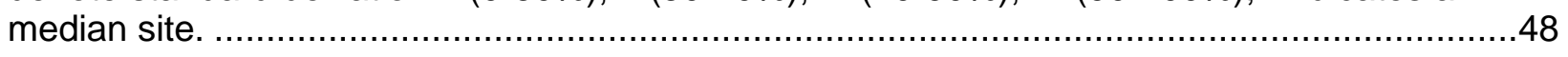

Figure 37: Average stem height per each site divided by cover class................................53

Figure 38: Average stem diameter per each site divided by cover class ..............................53

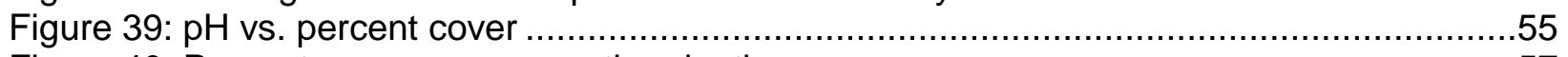

Figure 40: Percent cover vs. compaction depth....................................................5

Figure 41: Percent cover vs. slope; 25\%-75\% (box); min and max (whisker); and mean

(diamond).................................................................................................5

Figure 42: Percent cover vs. direction; 25\%-75\% (box); min and max (whisker); and mean

(diamond).

Figure 43: Percent cover vs. elevation 
Figure 44: Tall Fescue (Kentucky 31 Fescue) - Provided by Robert H. Mohlenbrock, hosted by the USDA-NRCS PLANTS Database / USDA SCS. 1989. Midwest wetland flora: Field office illustrated guide to plant species. Midwest National Technical Center, Lincoln........................74

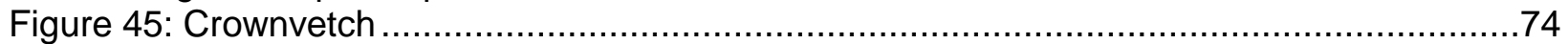

Figure 46: White Clover - Provided by Larry Allain, hosted by the USDA-NRCS PLANTS

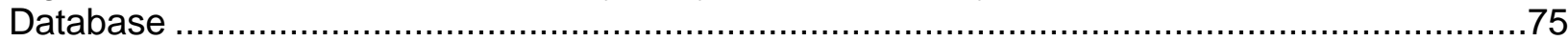

Figure 47: Red Clover - Provided by Rusty Russell, hosted by the USDA-NRCS PLANTS

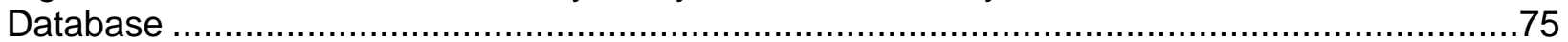

Figure 48: Annual Ryegrass - Provided by Larry Allain, hosted by the USDA-NRCS PLANTS

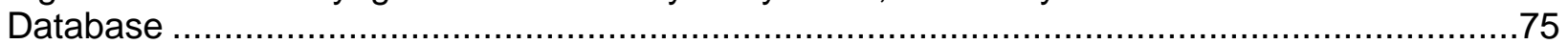

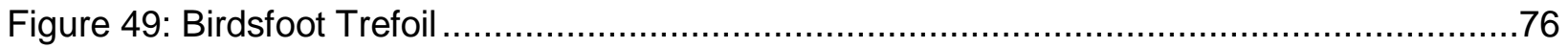

Figure 50: Buckhorn Plantain - Provided by Gary A. Monroe, hosted by the USDA-NRCS

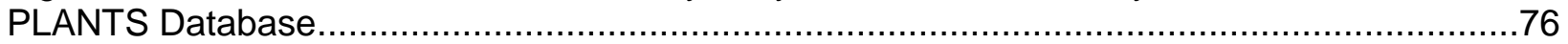

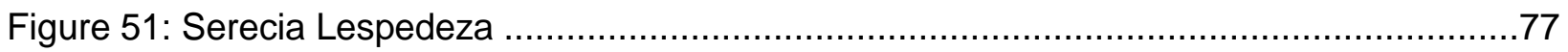

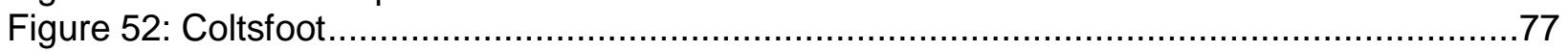

Figure 53: Marker flag placement for site location at I-68 median ......................................78

Figure 54: Soil compaction testing with penetrometer at $\mathrm{I}-68$ median....................................78

Figure 55: Vegetation stem measurement at I-68 median ...................................................79

Figure 56: Compaction testing with penetrometer at I-68 median ......................................... 79

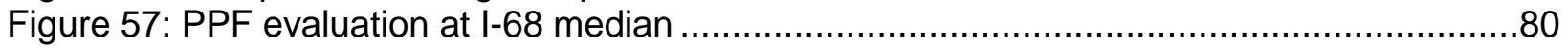

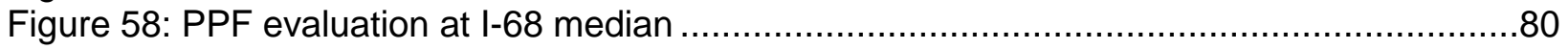

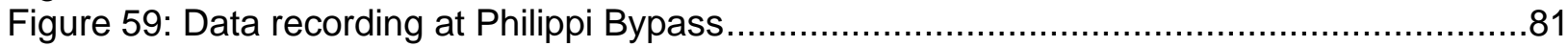

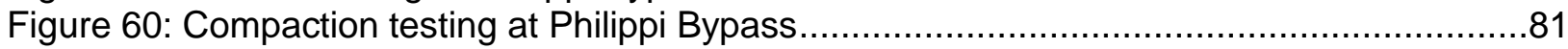

Figure 61: Compaction testing with penetrometer at Philippi Bypass …............................... 82

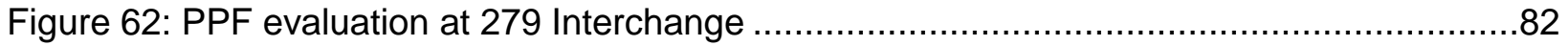

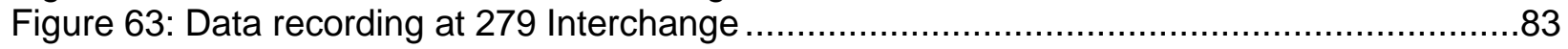

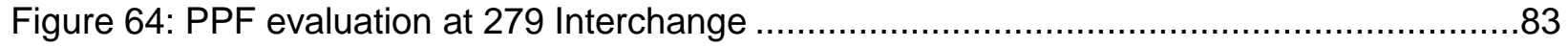

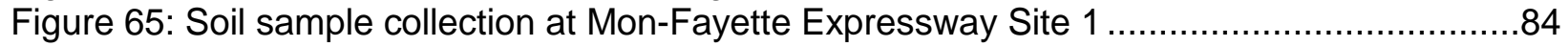

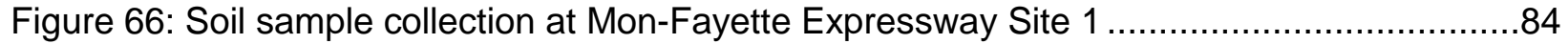

Figure 67: Researcher photograph concluding data collection at Mon-Fayette Expressway Site 1

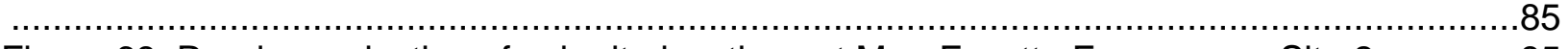

Figure 68: Random selection of sub-site locations at Mon-Fayette Expressway Site 2............85

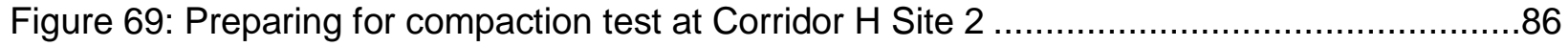

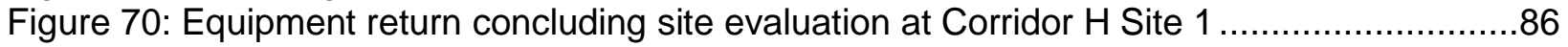

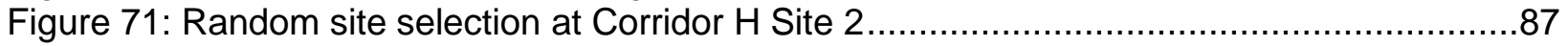

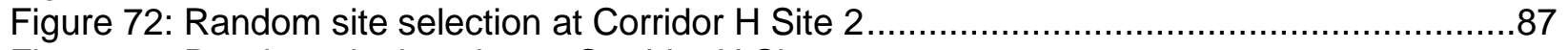

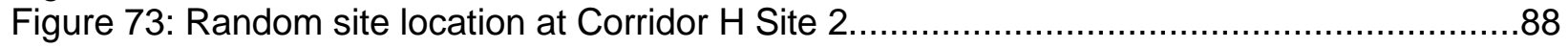

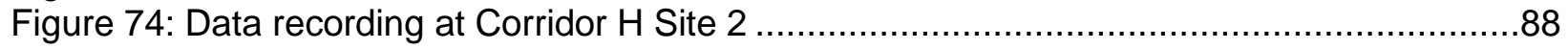

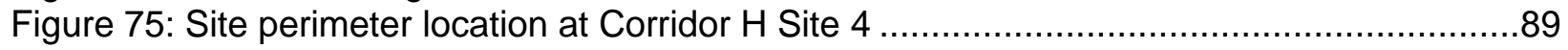

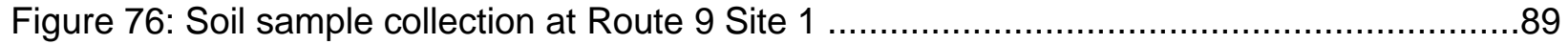

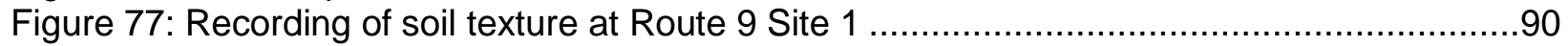

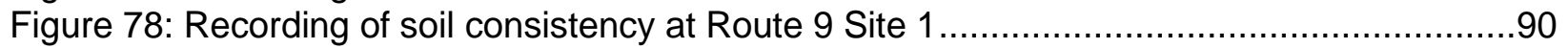

Figure 79: Soil sample collection at Route 9 Site 1 ...........................................................91

Figure 80: Measurement of slope with clinometer at Route 9 Site 1 ....................................91

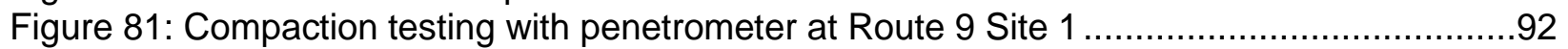

Figure 82: Compaction testing with penetrometer at Route 9 Site 1 .....................................92

Figure 83: Compaction testing with penetrometer at Route 9 Site $1 \ldots \ldots \ldots \ldots \ldots \ldots \ldots \ldots \ldots \ldots \ldots . . . . . . . . \ldots 3$

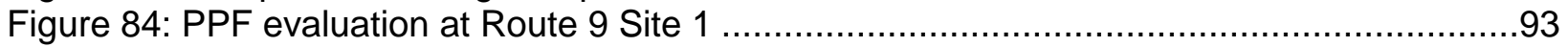

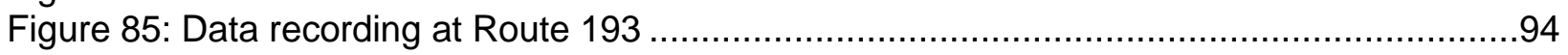

Figure 86: Random plot selection at East Beckley Bypass ...........................................94 


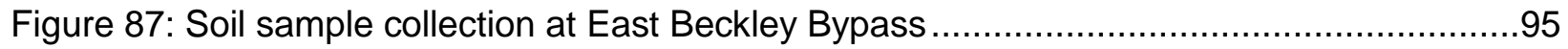

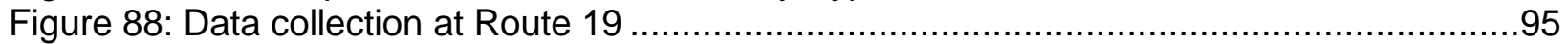

Figure 89: Field site form - general site location (front) .............................................

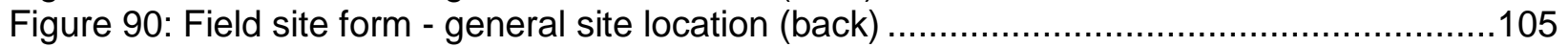

Figure 91: Field site form - sub-site location (front) ....................................................106

Figure 92: Field site form - sub-site location (back) .................................................... 107

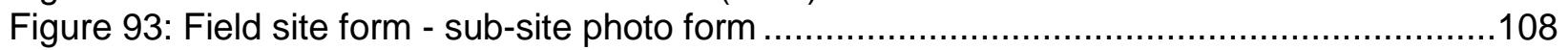


List of Tables

Table 1: Planting specification overview..... .22

Table 2: Acceptable seed type per state .24

Table 3: Parameters compared against percent cover for multilinear regression.....................47 Table 4: Species distribution among plants for each study site, divided by cover class (I: $0-50 \%$,

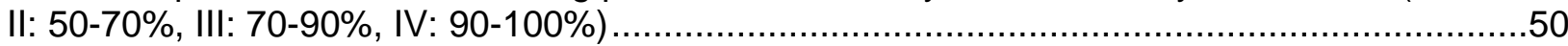

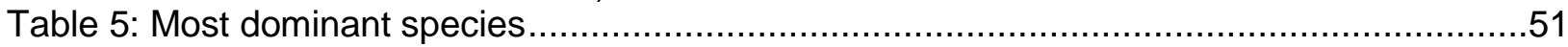

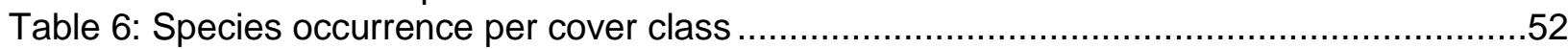

Table 7: Species occurrence per median site.............................................................52

Table 8: Physical and chemical properties of soil by cover class reporting median and range (in parentheses). Letters indicate statistical significance, and $n$ is the number of samples within each cover class.

Table 9: Regression statistics of step 1: percent cover and soluble salts

Table 10: Regression statistics of step 2: percent cover vs. soluble salts and percent organic matter

Table 11: Regression statistics of step 3: percent cover vs. soluble salts, percent organic matter, and average depth of compaction test

Table 12: Regression statistics the final step of Backward Elimination.

Table 13: Model predicting mean vegetation cover calculated by forward stepwise multiple regression analysis 


\section{Ch. 1 Introduction:}

\subsection{Background}

When driving through West Virginia, it can easily be seen that the soil conditions make it difficult for successful revegetation. Rock falls and bare slopes along roadways are an extremely typical observation. Thus, the focus of the project was to evaluate the effectiveness of the current reclamation practices that the West Virginia Division of Highways (WVDOH) currently uses along their roadsides and in the medians. The goal of this project was to evaluate current vegetative cover practices along major roadways throughout the state to determine if the current reclamation methods are adequately providing vegetative cover. This overall goal was met by 2 specific objectives,

1) Evaluate reclamation practices of the Appalachian Region with focus on the bordering states of West Virginia.

2) Evaluate the current reclamation practices of the West Virginia Division of Highways to determine if these practices were adequate in achieving long-term vegetative cover.

\subsection{Field Study Objectives}

To meet the first objective, these bordering states were evaluated for their reclamation procedures involving seeding, fertilizing and mulching by comparing the current state specification manuals. Also, published best management practices approved by the state agencies were consulted for more information.

For the second objective, thirty-three roadside and median study sites were selected and incorporated variability in soil type, elevation, vegetation establishment and cover, seed mixture, slope, aspect, age (<15 years), and climate. Vegetation cover was measured, and species distribution was identified. Slopes, aspects of the sloping face, and elevations were recorded. Soil samples were tested for nutrients, minerals, texture, and $\mathrm{pH}$. 


\section{Ch. 2 Literature Review:}

\subsection{Review of Current Specifications}

A survey of state specifications for seed mixtures was completed for West Virginia and surrounding states. State mixtures and specifications evaluated included the following:

- WVDOH

- Ohio

- Kentucky

- Tennessee

- Virginia

- Maryland

- Pennsylvania

- North Carolina

- South Carolina

- New York

- WVDEP

The West Virginia Department of Environmental Protection temporary and permanent seeding regulations used for mine reclamation were also reviewed. The specifications are summarized in the following sections.

\subsubsection{West Virginia Division of Highways (WVDOH)}

Seeding in the State of West Virginia must be performed between the dates of March 1June 15 and August 1-October 15. There are four areas considered for planting regions: Area B (Medians, shoulders, waterways, and mowable area), Area C (Course and fine lawn grass),

Area D (Cut and fill slopes), and Area L (All areas) (WVDOH 2010).

For temporary seed applications one mixture is recommended:

- Annual ryegrass

- Barley or oats

- Millet

- Cereal rye or cereal wheat

The area $\mathrm{B}$ seed mixture is composed of the following species:

- Tall fescue

- Red fescue

- White Dutch clover 
- Annual ryegrass or weeping lovegrass

The area $\mathrm{C}-1$ seed mixture is composed of the following species:

- Tall fescue

- Red fescue

- Kentucky bluegrass

- Annual ryegrass or weeping lovegrass

The area C-2 seed mixture is composed of the following species:

- Red fescue

- Kentucky bluegrass

- Merion bluegrass

- Annual ryegrass or weeping lovegrass

The area $\mathrm{D}$ seed mixture is composed of the following species:

- Tall fescue

- Red fescue

- Crownvetch

- Annual ryegrass or weeping lovegrass

The area $L$ seed mixture is composed of the following species:

- Red fescue

- Annual ryegrass or weeping lovegrass

- Hard fescue

When fertilizing in the State of West Virginia, it is recommended but not required that a $\mathrm{pH}$ test be performed prior to fertilizing. One of three acceptable fertilizers is to be used. The acceptable fertilizer types are nitrogen, phosphoric acid, and potash types. All of the acceptable types must be of nutrient value 10-20-10. Also, after a $\mathrm{pH}$ test is completed, agricultural limestone may be used to prepare soil for seed (WVDOH 2010).

There are three acceptable mulch types for use throughout the State of West Virginia: straw mulch (slopes less than 1.5:1), hydraulic seeding (slopes greater than 1.5:1), and wood chips. When using straw mulch, it is recommended that the straw be anchored with asphalt. 
Another chemical binder may be substituted for asphalt. Also, when wood chips are used as mulch, the wood chips must be recovered from clearing or grubbing or bark (WVDOH 2010).

\subsubsection{Ohio}

Specifications for seeding and mulching for Ohio require that seeding and mulching is completed within one week of obtaining final grade. If soil tests are required by the job plans for the soil or topsoil, lime is used to meet a pH value of at least 6.5. If soil tests are not required, lime (granular or liquid) is applied at a standard rate (granular: 2 tons/acre $\left(448.3 \mathrm{~g} / \mathrm{m}^{2}\right)$, liquid: 5 gal/acre(46.77 L/ha)). Commercial fertilizer (dry or liquid), 10-20-10, is applied at a rate of $20 \mathrm{lb}$

per $1000 \mathrm{ft}^{2}\left(9.78 \mathrm{~g} / \mathrm{m}^{2}\right)$. Reapplied topsoil should not contain more than $40 \%$ clay. The use of Ohio EPA rated Class IV is acceptable (ODOT, 2013).

Multiple grass and wildflower seed mixtures, each with a preferred slope, are presented in the specification: Class 1) lawn mixture, Class 2) roadside mixture, Class 3A) slope mixture (for slopes less than or equal to 3:1), Class 3B) low growing slope mixture (for steeper than 3:1), Class 3C) crown vetch mixture (steeper than 3:1, shale or rock slopes), Class 4A) native grass mixture (flatter than 2:1), Class 4B) low growing native grass mixture (flatter than 2:1), Class 5A) annual perennial wildflower mixture (flatter than 2:1), Class 5B) native wildflower and grass mixtures (flatter than 2:1), Class 6) wildlife mixture, and 7 Class) temporary erosion control mixture (ODOT, 2013).

Mulch must be placed within 24 hours of seeding. Straw, compost or wood fiber mulch can be used on slopes less than or equal to 3:1. Mulching should not occur during high winds. Hydraulic mulching methods should be used on windy slopes (ODOT, 2013).

A second soil test should be completed after 3 months. The soil test will determine if repeated fertilization is necessary (ODOT, 2013). 


\subsubsection{Kentucky}

The State of Kentucky requires that temporary seeding must be applied to work areas that will be inactive for 21 days, and the work areas must be mulched within 14 days of seeding. For permanent seeding procedures, it is specified that all work areas that have reached final grade be seeded within 14 days. The soil must be able to support seed growth and it must contain at least $25 \%$ of silt and clay for purposes of maintaining adequate moisture. In the event that soil need be compacted, the compaction must occur in $6-8$ in $(15.24-20.32 \mathrm{~cm})$ lifts for proper seed root stability (KYBMPs).

For the considerations of seed in the State of Kentucky, specifications were implemented for both temporary and permanent seeding applications. Temporary seeding has specifications for two mixtures specified by planting dates:

- $\quad$ Mixture 1 (Mar 1-Oct. 31)

- Oats

- Perennial ryegrass

- Tall fescue

- Wheat

- Annual rye

- $\quad$ Mixture 2 (Nov. 1-Feb. 28)

- Annual rye

- Wheat

- Perennial ryegrass

- Tall fescue

It is also recommended that seed not be planted more than a depth of $4 \mathrm{in} .(10.16 \mathrm{~cm})$ when using for temporary applications (KYBMPs).

Permanent seeding applications, on the other hand, have many stipulations. First, the Kentucky Transportation Cabinet has two seed mixtures that are ultimately recommended: Mixture 1 and Mixture 3 (KYBMPs):

- Mixture 1 
- $75 \%$ Tall fescue

- $10 \%$ Red top

- $5 \%$ White dutch clover

- $10 \%$ Ryegrass ( perennial)

- Mixture 3

- $30 \%$ Tall fescue

- $15 \%$ Red top

- $15 \%$ Partridge pea

- $20 \%$ Sericea lespedeza

- $10 \%$ Sweet clover - yellow

- $10 \%$ Ryegrass

Although the Cabinet has the above mentioned preferred seed mixtures, there are specifications for by area of usage. Areas of usage are as follows:

- Flat or slightly sloped

- Steep slope, banks, cuts, or other low maintenance areas (not mowed)

- Lawns and high maintenance areas (mowed)

- Channels and areas of concentrated water flow.

Each of the above mentioned areas of consideration have separate recommended seed mixtures that are noted in the specification (KYBMPs).

Fertilizer, lime, and seed should not be applied before heavy rain. Lime is recommended to be spread on acidic soils that have a pH of 5.5 or less. Soil tests are recommended to be performed to assure that excess lime is not used. Lime shall be spread at one ton per acre and must be ground agricultural limestone. Fertilizer may be applied at a rate of no more than 800 pounds per acre $\left(89.67 \mathrm{~g} / \mathrm{m}^{2}\right)$ of a mixture comprised of $10-10-10(10-0-10$ for areas near streams or rivers). Both fertilizer and lime is required to be worked into the soil by disc or springtooth harrow at 4 in. $(10.16 \mathrm{~cm})$ deep (KYBMPs).

For mulching procedures where surface cover is the goal, bark, wood chips, and straw are acceptable. On steep slopes greater than 2.5:1 hydromulch is preferred. Straw or hay (applied at 1.5 to 2.5 tons per acre (336 to $\left.560 \mathrm{~g} / \mathrm{m}^{2}\right)$ ); wood chips, bark, or sawdust (applied at 
5 to 8 tons per acre $\left(1.12\right.$ to $\left.1.79 \mathrm{~kg} / \mathrm{m}^{2}\right)$ ); rock (applied at 200 to 500 tons per acre (44.83 $112.1 \mathrm{~kg} / \mathrm{m}^{2}$ ) only on slopes flatter than $2: 1$ ); hydraulic mulches and soil binders (applied at 1.5 to 2 tons per acre (336 to $\left.560 \mathrm{~g} / \mathrm{m}^{2}\right)$ ) are all acceptable to be used for mulching purposes (KYBMPs).

\subsubsection{Tennessee}

The State of Tennessee is divided into three regions: Region 1, 2, and 3. Seed mixtures are required to be planted according to the region the specific mixture is associated to as well as the recommended season for planting (TDOT).

Region 1 (west) is comprised of poorly to well drained soils and grass channels. There are three different mixture combinations approved for use in Region 1: Mixture 1, Mixture 2, and Mixture 3. The recommended soil types for the three mixtures are listed below:

- Mixture 1 (Poorly drained)

- Pensacoal bahiagrass

- Bermudagrass hulled

- Korean lespedeza

- Kobe lespedeza

- $\quad$ Mixture 2 (Well drained)

- Pensacoal bahiagrass

- Bermudagrass hulled

- Korean lespedeza

- Foxtail millet

- $\quad$ Mixture 3 (Grass channels)

- Bermudagrass

Region 2 (central) is comprised of moderate slopes greater than $6 \mathrm{in}$. $(15.24 \mathrm{~cm})$ of soil and poor and/or shallow soils. There are three different mixture combinations approved for use in Region 2; Mixture 1, Mixture 2, and Mixture 3. The recommended soil types for the three mixtures are listed below: (TDOT).

- Mixture 1 (Slopes or poor/shallow soils) 
- Pensacoal bahiagrass

- Bermudagrass hulled

- Korean lespedeza

- Kobe lespedeza

- Mixture 2 (Roadside channels and ditches)

- Pensacoal bahiagrass

- Bermudagrass hulled

- Korean lespedeza

- Kobe lespedeza

- $\quad$ Mixture 3 (Grass channels)

- KY 31 fescue

- Bermudagrass hulled

Region 3 (east) is comprised of steep slopes with considerations for soils above and below $2500 \mathrm{ft}(762 \mathrm{~m})$ in elevation. There are four different mixture combinations approved for use in Region 3; Mixture 1, Mixture 2, Mixture 3, and Mixture 4. The recommended soil types for the four mixtures are listed below:

- Mixture 1 (Mountainous areas):

- KY 31 fescue

- Kobe lespedeza

- Korean lespedeza

- Redtop

- $\quad$ Mixture 2 (Shallow soils):

- KY 31 fescue

- Korean lespedeza

- Redtop

- Crown vetch

- Mixture 3 (Soils > 6 inches):

- KY 31 fescue

- Kobe lespedeza

- Korean lespedeza

- Mixture 4 (Roadside channels):

- KY 31 fescue

- Italian ryegrass 
- Smooth bromegrass

All of the mixtures for each region have seed specifications and recommended planting dates that can be seen in the specification (TDOT).

Temporary seeding is acceptable to be used when construction is on-going for up to 18 months. When using a temporary seed application, mulch, or some sort of ground cover, must be used. Temporary grass seed specifications for the state of Tennessee are common throughout all three regions. There are two mixtures, Mixture 1 and Mixture 2, which are approved for temporary seeding applications.

- Mixture 1

- German millet

- Sudangrass

- Mixture 2

- Annual Ryegrass

- Foxtail millet

The recommended planting times can be seen in the specification (TDOT).

There are four types of approved fertilizers that may be used in Tennessee with the three normal main ingredients: nitrogen, phosphorus, and potassium. The approved mixture type is 10-20-20. The four types of fertilizers can be seen in the specification (TDOT).

Mulch should be applied within 24 hours of when seed was spread. Mulching should not occur during high wind, and foot, equipment, and vehicular traffic are to be prohibited after application. Straw and hay mulch, cellulose fiber mulches, "hydromulch" (used with a tacifier), bonded fiber matrix (BFM) (used on slopes up to 2:1), erosion control blankets (only if specified in plans), and temporary flexible channel liners (roadside channels) are all acceptable for mulching applications (TDOT). 


\subsubsection{Virginia}

Specifications for seed applications in the State of Virginia require that the Engineer be notified at least 48 hours prior to beginning work (VDOT, 2007).

To prepare soil for seed, soil must be loosened or tilled to a depth of approximately 3 in. $(7.62 \mathrm{~cm})$ on slopes up to $3: 1$. Slopes that are greater than $3: 1$ are not required to be loosened unless the surface is hard or crusted over. Also, any debris in the soil that is larger than 3 in. $(7.62 \mathrm{~cm})$ in diameter must be removed prior to seed application (VDOT 2007, 2013, VDOTSPEC).

Lime is required to be an agricultural grade lime and should be applied at a rate of 2 tons per acre $\left(448.3 \mathrm{~g} / \mathrm{m}^{2}\right)$ in a uniform fashion. Wet and dry fertilizers are both approved to be used in the state of Virginia. When a dry mixture formula of fertilizer is to be used, it must be applied at the time of seeding at a rate of 300 pounds per acre $\left(33.63 \mathrm{~g} / \mathrm{m}^{2}\right)$ and be a $10-20-10$ mixture. When using a wet formulated fertilizer, the same nutrition value must be upheld. The expected nutrition value is 45 pounds of nitrogen per acre $\left(5.04 \mathrm{~g} / \mathrm{m}^{2}\right)$ (VDOT 2007, 2013, VDOTSPEC).

Temporary seeding is expected to be used when a work area is to be undisturbed for 15 or more days. A contractor's mixture of VNS fescue and a nurse crop or a fescue cultivator from the VDOT Roadside Vegetation Management Approved Species and Cultivators list are approved for temporary and permanent seeding applications. Any mixture that is to be used from the Vegetation Management list must be approved by the engineer. The approved seeds are listed below:

- Tall fescue

- Weeping lovegrass

- Winter ryegrass

- Sericea lespedeza

- Kentucky bluegrass

- Fine hard fescue

- Zoysiagrass

- Crownvetch

- Triticum aestivum wheat 
- Common bermudagrass

- Barley

- Flat pea

- Fine creeping red fescue

- German foxtail millet

- Bermudagrass

- White dutch clover

- Fine chewings fescue

- Annual ryegrass

- Orchardgrass

- Birdsfoot trefoil

Mulch should be applied within 48 hours of when seed was spread; however, mulch is not needed on areas that have been over seeded. Straw and hay mulch ( 2 tons per acre (448.3 $\left.\mathrm{g} / \mathrm{m}^{2}\right)$ ), wood cellulose fiber mulches $\left(1,500\right.$ pounds per acre $\left(168.1 \mathrm{~g} / \mathrm{m}^{2}\right)$ ), and wood chips (no larger than $6 \mathrm{in}^{2}\left(38.71 \mathrm{~cm}^{2}\right)$ in area) are all acceptable for mulching applications. Wet straw or hay is not permitted for use. When straw or hay is used, it must be anchored by some means approved by engineer (VDOT 2007, VDOT 2013, VDOTSPEC).

\subsubsection{Maryland}

The State of Maryland is divided into three regions by specified counties. Region 1 is comprised of Garrett, Allegany, and Washington (West of Clear Spring, MD). Region 2 is comprised of Washington (East of Clear Spring, MD), Fredrick, Carroll, Baltimore, Harford, Cecil, Howard, Montgomery, and Baltimore City. Region 3 is comprised of Anne Arundel, Prince George's, Calvert, Charles, St. Mary’s, Kent, Queen Anne's, Talbot, Caroline, Dorchester, Wicomico, Worcester, and Somerset. Also, each region has specified planting dates. The planning dates are as follows: Region 1 (4/1 to 11/1); Region 2 (3/1 to 11/20); and Region 3 (3/3 to $11 / 30)$ (MSA 2005e).

Maryland State Highway Administration (SHA) provides specifications for both permanent and temporary seed mixtures. The contents of both mixtures are presented below:

- Permanent Mixture

- Tall fescue 
- Kentucky bluegrass

- Perennial ryegrass

- Temporary Mixture

- Barley or rye

- Foxtail millet

The State of Maryland also has approved seed combinations for different planting seasons. The acceptable seed groups; warm season grasses, cool season grasses, miscellaneous mixture are listed. Also, there are specifications for erosion control seeding which consist of 9 various mixtures listed in the specification (MSA 2005c, d, e).

- Warm season grasses

- Weeping lovegrass or lehmann lovegrass

- Foxtail millet

- Cool season grasses

- Barley

- Oats

- Cereal rye

- Wheat

- Annual ryegrass

- Mixtures

- Barley or cereal rye

- Foxtail millet

- Additive seeds

- Lehmann lovegrass

- Foxtail millet

- Certified sericea

- Lespedeza

- Other seed

- Crimson clover

- Crownvetch

- Certified fults or salty alkali grass

There are multiple fertilizer mixtures approved for use. Each mixture has separate stipulations and application rates. The approved mixtures are 10-20-20, 10-22-22, 18-18-18, 18- 
24-12, and 19-19-19. The application rates and special considerations are presented in the specifications (MSA 2005a, d).

Wood fiber mulch, paper hydraulic mulch, wood fiber + paper hydraulic mulch, erosion control blankets, and straw mulch are all approved for use as mulch. Straw mulch is subdivided into four classes specifying application zones. Each of the above mentioned mulches have individual requirements listed in the specification. Binders and tackifiers are approved for keeping mulches in place. Also, staples may be used to secure erosion control blankets to soil (MSA 2005b).

\subsubsection{Pennsylvania}

Pennsylvania Department of Transportation recommends that a soil test be performed prior to seeding or mulching applications. A soil test can help confirm proper seed mixture selection as well as the proper seed supplication rates (PennDOT 1998).

The State of Pennsylvania authorizes multiple methods to seed throughout the state. Seed may be distributed by helicopter, broadcasting, hydraulic placement, drilling, and hand seeding. Whenever the hydraulic seeding method is used, it is recommended that seed and mulch be separately applied in order to aid in seed to soil contact. There are six seed mixtures with individual planting date specifications. The individual requirements for each mixture type are listed below:

- Formula B

- Perennial ryegrass mixture

- Creeping red fescue or chewings fescue

- Kentucky bluegrass mixture

- Formula C

- Crownvetch

- Annual ryegrass

- Formula D

- Tall fescue

- Creeping red fescue or Chewings fescue

- Formula E

- Formula L

- Annual ryegrass 
- Hard fescue mixture

- Creeping red fescue

- Formula W

- Annual ryegrass

- Tall fescue

- Birdsfoot trefoil mixture

- Redtop

Each mixture also has a recommended planting date that can be seen in the specification (PennDOT 1998).

After completion of a required soil test, fertilizer may be required for use in soil for seeding purposes in different required amounts. The approved fertilizers are listed with the recommended general mixture (PennDOT 1998):

- Pulverized agricultural limestone

- 800 pounds per 1000 square yard $\left(434 \mathrm{~g} / \mathrm{m}^{2}\right)$

- 10-20-20 commercial fertilizer

- 140 pounds per 1000 square yard $\left(75.95 \mathrm{~g} / \mathrm{m}^{2}\right)$

- 38-0-0 ureaform fertilizer

- 50 pounds per 1000 square yards $\left(27.12 \mathrm{~g} / \mathrm{m}^{2}\right)$

- sulfur coated urea

- $50-59$ pounds per 1000 square yards $\left(27.12-32.01 \mathrm{~g} / \mathrm{m}^{2}\right)$

- IBDU (isobutylidene diurea slow-release nitrogen fertilizer)

- 61 pounds per 1000 square yards $\left(33.09 \mathrm{~g} / \mathrm{m}^{2}\right)$

All mulch to be spread in seeding applications must be free from all foreign materials, stems and plant toxins. Straw or hay, wood fiber (hydromulch), and pellet mulch are all approved for use. Several methods are approved for use in applying the mulch. Hay or straw mulch may be blown using a blower, but regardless of the method of application, straw mulch must be anchored immediately after application in order to prevent wind blowing mulching away. Wood fiber must be hydraulically applied (PennDOT 1998).

\subsubsection{North Carolina}

Seed must be free of seeds from the undesirable plant list that is presented in the specification in order to be approved for planting. When performing permanent seeding, seed must be spread no more than 15 days after reaching final grade. There are 6 seed groups that 
are approved for permanent seeding applications: Seed group 1 (85\% pure live seed), Seed group 2 (80\% pure live seed), Seed group 3 (78\% pure live seed), Seed group 4 (76\% pure live seed), Seed group 5 (70\% pure live seed), and Seed group 6 (70\% pure live seed) (NCDOTa, NCDOT 2012).

Temporary Seeding must have seed planted at a depth of no less than $5 \mathrm{in} .(12.7 \mathrm{~cm})$ unless specified otherwise by the engineer. Temporary seeding is required to be done when construction operations are suspended for 15 days or more, final grade is reached prior to paving, permanent seed is not in season, or cover is needed to prevent erosion (NCDOT 2012, NCDOT 2003).

In the State of North Carolina, fertilizer may contain no urea. There are several specifications for fertilizers used in various applications. All of the application types and acceptable fertilizers are presented in the specifications. All fertilizer types must be in compliance with the North Carolina Fertilizer Law (NCDOTb, NCDOT 2012).

Straw or hay mulch may be used anytime throughout the year. Erosion control blankets are approved for use in ditches, on steep slopes, and on slopes less than 2:1 (NCDOT 2012, NCDOT 2003).

\subsubsection{South Carolina}

The State of South Carolina is divided into two parts: upper region and lower region. In both regions, the area of planting must be loosened to 3 in. $(7.62 \mathrm{~cm})$ to begin planting operations. Any debris larger than $2.5 \mathrm{in} .(6.35 \mathrm{~cm})$ must be removed from the seedbed. Seeds are classified by approved sites (slopes, shoulders, or medians), planting rate (lbs/acre), planting location (upper region or lower region), and planting dates (identified by month) (SCDOT 2011a).

For all permanent cover and permanent grassing for small projects, the contractor must choose a minimum of two seed types from the list of perennials. One must be a turf-type 
species. Also, a minimum of one annual nurse crop is selected from the annual seed list that is presented in the specification. Permanent planting in medians and shoulders in the lower region are the only two exceptions from using two permanent cover species. Medians and shoulders in the lower part of the state may use a minimum of one turf-type species and one acceptable annual nurse crop (SCDOT 2011a).

Three forms of fertilizer are acceptable for use in the State of South Carolina: agricultural lime, fast acting lime (liquid and dry), and granular fertilizer (slow-release). All three forms of fertilizer are acceptable for permanent seeding applications, and the fertilizer must conform to the state fertilizer law in order to be acceptable for use (SCDOT 2011a).

When performing temporary or permanent seeding applications, mulch is required to be used on all applications. The only exception is on resurfacing projects or shoulder work that have a disturbed area of $6 \mathrm{ft}(1.83 \mathrm{~m})$ or less that will be seed by means of a culti-packer or light roller. Wood chips are not acceptable for use as mulching applications. When straw mulch is used, it must be free of weeds or mature seed-bearing stalks, and must be anchored with an approved tackifier. Straw mulch is not acceptable for use in urban areas or adjacent to sidewalks, guardrails, curbs, gutters, or concrete medians. It is also not acceptable to be used on slopes steeper than 4:1. Also, hydraulic erosion control products (HECPs) are approved to be used for mulching practices (SCDOT 2011a).

Four types of HECP are recommended by a secondary code when HECP is used. HECP 1, HECP 2, HECP 3, and HECP 4 are the different hydraulically applied mulches accepted for use. These four mulches are limited by several factors including the slope of the application site as well as the minimum application rates. The specific requirements for each of the HECP types are presented in the specification (SCDOT 2011b). 


\subsubsection{New York}

The State of New York has several specifications in order to begin the seeding process. First, it is required that the engineer be notified two days prior to seeding. Seedbeds are required to be properly prepared to ensure good seed to soil contact. Soil should be loosened up to a depth of 12 in $(30.48 \mathrm{~cm})$ prior to permanent seeding in areas that are extremely compacted. Any debris that is $4 \mathrm{in} .(10.16 \mathrm{~cm})$ or larger should be removed from seeding area. Also, in permanent seeding applications, providing that the proper amount of mulch and moisture is available, it is acceptable to permanently plant any time of the year (NYSDOT 2002, NYDEC 2005).

Seed in the State of New York is recommended to be directly distributed to soil and evenly spread. There are six different permanent seed combinations recommended by the State Handbook for uses in different situations: Mixture 1 (extremely shaded areas), Mixture 2, Mixture 3 (sand and gravel applications), Mixture 4 (tidal shorelines and marshes), Mixture 5 (tidal shorelines and sand stabilization), Mixture 6 (general purpose). For temporary seeding, two seed types are recommended for specific times of the year: Ryegrass (spring-early fall) and Winter Rye or Cereal Rye (late fall-early spring). Application rates are presented in the specification (NYDEC 2005).

Fertilizer may be used in the State of New York; however, it is not typically used in temporary seeding applications. It is recommended that prior to fertilizing any soil that a soil test be performed. Commercial grade fertilizer is acceptable when a 5-10-10 formula, or equivalent, is used. If fertilizer needs to be applied prior to a soil test being performed, the $5-10-10$ fertilizer must be applied at 600 pounds per acre $\left(67.25 \mathrm{~g} / \mathrm{m}^{2}\right)$ (NYSDOT 2002, NYDEC 2005).

For the State of New York mulch must be spread no later than $72 \mathrm{hr}$ after seeding. There are many types of mulch that are acceptable. For temporary mulching, hay or straw mulch and wood fiber are acceptable. For permanent mulching, wood chips (10 - 20 tons per acre (2.24 - 
$\left.4.48 \mathrm{~kg} / \mathrm{m}^{2}\right)$ ), wood fiber cellulose (2000 pounds per acre $\left.\left(224.2 \mathrm{~g} / \mathrm{m}^{2}\right)\right)$, gravel, crushed stone, or slag (405 cubic yards per acre $\left.\left(7.65 \mathrm{~cm}^{2} / \mathrm{cm}\right)\right)$, hay or straw $\left(2\right.$ tons per acre $\left.\left(448.3 \mathrm{~g} / \mathrm{m}^{2}\right)\right)$, jute twisted yarn, excelsior wood fiber mats, compost (134-402 cubic yards per acre (2.53 $\left.7.59 \mathrm{~cm}^{2} / \mathrm{cm}\right)$ ), and straw or coconut fiber (81 rolls per acre ) are all acceptable forms of mulch. Straw or hay mulch is the most common used type of mulch (NYSDOT 2002, NYDEC 2005).

\subsubsection{West Virginia Department of Environmental Protection (WVDEP)}

Currently the West Virginia DEP has specified that the State of West Virginia be split into three regions. The regions are the western region, ridge and valley region, and mountain region. They are comprised by differences in the types of soil, climate, and topography (WVDEP 2006b).

For seeding, the WVDEP currently has 29 approved mixtures of grass seed for permanant seeding applications. These mixtures are categorized by types of maintenance required, planting dates, and recommended application sites. It is also noted in most of the seed mixtures that a nurse crop is to be applied after a certain date. The list of acceptable nurse crops is presented in the specification as well as the acceptable planting date for each of the accepted seeds. It should be noted that in temporary seeding applications the approved seed types and planting dates are the same as the approved nurse crops. Furthermore, it is specified that certain seeds have special permitted areas for planting. Also, the DEP does offer a specification for a general seed mixture for both temporary and permanent seeding applications. The specifications of each mixture type are presented in the specification (WVDEP 2006a, 2006b, 2010).

It is recommended that a soil test be performed prior to fertilizing. Commercial fertilizer (slow release, 10-20-10 mixture), Lime (agricultural grade), and conditioners (peat, sand, vermiculite, etc.) are all acceptable forms of soil treatment, but soil testing should be performed before hand (WVDEP 2010). 
Mulching operations in the State of West Virginia are mandatory directly after seeding is completed. Two forms of mulch are acceptable by the DEP: baled straw mulch and wood cellulose fiber. Baled straw is to be distributed at a rate of 2 tons per acre $\left(44.83 \mathrm{~g} / \mathrm{m}^{2}\right)$ and is recommended to be fastened. The wood cellulose fiber is applied at a rate of 1,500 pounds per acre $\left(168.1 \mathrm{~g} / \mathrm{m}^{2}\right)$ and only used on slopes greater than or equal to $2 \mathrm{H}: 1 \mathrm{~V}$ (WVDEP 2010).

\subsection{Comparing WV 652 and WVDEP Specifications:}

The major differences noted below are for the two specifications provided for West Virginia. The West Virginia DEP and the West Virginia DOH both offer specifications for seeding and mulching applications. First, the most noted difference is that the WVDEP breaks the state into three regions: western plateau, ridge and valley region, and mountains. The WVDOH breaks the state up in a different way. There are four areas considered for planting regions: Area B (Medians, shoulders, waterways, and mowable area), Area C (Course and fine lawn grass), Area D (Cut and fill slopes), and Area L (All areas).

Next, the noted differences are in the acceptable seed types from the DEP that are not accepted by WVDOH:

\section{- Permanent Applications}

$\begin{array}{ll}\circ & \text { Alfalfa } \\ \circ & \text { Big bluestem } \\ \circ & \text { Birdsfoot trefoil } \\ \circ & \text { Clover } \\ \circ & \text { White clover } \\ \circ & \text { Deer tongue } \\ \circ & \text { Eastern gamagrass } \\ \circ & \text { Indiangrass } \\ \circ & \text { Tall fescue } \\ \circ & \text { Ladino clover } \\ \circ & \text { Little bluestem } \\ \circ & \text { Orchardgrass } \\ \circ & \text { Perrenial pea } \\ \circ & \text { Perrenial ryegrass ladino } \\ \circ & \text { Perrenial ryegrass } \\ \circ & \text { Redtop }\end{array}$


- Reed canarygrass

- Serecia lespedeza

- Sideoats grama

- Switchgrass

o Timothy

- Temporary Applications

- Annual ryegrass

- Field bromegrass

- Foxtail millet

- German millet

- Hairy vetch

- Japanese millet

- Redtop

- Spring oats

- Winter rye

- Winter wheat

The use of fertilizers is very similar between WVDEP and WVDOH. The two notable differences are that the use of conditioners is acceptable according to the WVDEP, and The WVDEP specifies lime and mulching rates following a soil test (WVDEP 2006b). The WVDOH specifications do not mention such usages.

For mulching purposes, both WVDEP and WVDOH approve the use of baled straw; however, WVDOH also accepts the use of wood chips recovered from clearing or grubbing operations. Also, WVDOH requires the use of hydraulic seeding on slopes greater than 1.5:1.

\subsection{Comparing WV 652 and nearby States:}

Specific comparisons among states based on state division, seed mixtures, fertilizer, lime, and mulch requirements are provided in Table 1. West Virginia DOT does not specifically break down the state into individual sectors like Tennessee (3 separate regions), Maryland (3 separate regions), South Carolina (upper and lower), and West Virginia DEP (3 separate regions). However, West Virginia does specify planting regions and recommended planting dates like New York, Kentucky, Ohio, and Pennsylvania. Also, table 2 compares all of the seed types that are acceptable within each state. The table specifies the acceptable mixtures that the 
seeds are used in within the state, which seeds are flowers, and the acceptable use for each seed type.

Fertilizing in the State of West Virginia is similar to the other compared states in the fact that a commercial fertilizer mixture is specified. The other 10 states and the West Virginia DEP all specify a commercial fertilizer mixture, but some states like Maryland are more detailed with their acceptable fertilizer types. Also, along with the West Virginia DEP, 5 out of the 10 states (South Carolina, Kentucky, New York, Ohio, Maryland, and WVDEP) require soil tests when applying lime or fertilizer to the soil.

Mulching applications in the State of West Virginia are similar to the specifications of other states in the fact that straw mulch, hydraulic seeding, and wood chips are acceptable. Other states do accept other forms of mulching (erosion control blankets, wood fiber matrix, etc), but every state accepts straw as mulch which is the same as West Virginia. 
Table 1: Planting specification overview

\begin{tabular}{|c|c|c|c|c|c|}
\hline State & State division & Seed mixtures & Fertilizer & Lime & Mulch \\
\hline $\mathrm{OH}$ & $\mathrm{N} / \mathrm{A}$ & $\begin{array}{l}\text { - } 10 \text { mixtures provided } \\
\text { Divided by slope, } \\
\text { location (i.e. in front of } \\
\text { residences, commercial } \\
\text { properties, etc.), and } \\
\text { habitat }\end{array}$ & $\begin{array}{l}\text { - Liquid or dry, } \\
10-20-10(20 \\
\left.\text { lbs/1000 } \mathrm{ft}^{2}\right)\end{array}$ & $\begin{array}{l}\text { - Granular or } \\
\text { liquid }\end{array}$ & $\begin{array}{l}\text { - Straw, compost or } \\
\text { wood fiber for } 3: 1 \\
\text { slopes (or less) } \\
\text { - Hydraulic mulch for } \\
\text { windy areas }\end{array}$ \\
\hline KY & $\mathrm{N} / \mathrm{A}$ & $\begin{array}{l}\text { - } 6 \text { mixtures provided } \\
\text { Divided by slope, } \\
\text { location (i.e. in front of } \\
\text { residences, commercial } \\
\text { properties, etc.), and } \\
\text { habitat }\end{array}$ & $\begin{array}{l}\text { - } 10-10-10 \text { (no } \\
\text { more than } \\
800 \text { pounds } \\
\text { per acre) } \\
\text { - } 10-0-10 \\
\text { (streams and } \\
\text { rivers) }\end{array}$ & $\begin{array}{l}\text { - Ground } \\
\text { agricultural } \\
\text { limestone (1 } \\
\text { ton per acre) }\end{array}$ & $\begin{array}{l}\text { - Straw or hay (2-4 } \\
\text { inches deep) } \\
\text { - Wood chips or bark } \\
\text { (2-3 inches deep) } \\
\text { - Hydraulic mulches }\end{array}$ \\
\hline TN & 3 Regions & $\begin{array}{l}\text { - } 3 \text { mixtures for Region } 1 \text {; } \\
3 \text { mixtures for Region } 2 \text {; } \\
4 \text { mixtures for Region } 3 \\
\text { - Seed classified by } \\
\text { location (roadside } \\
\text { channels, ditches, } \\
\text { mountainous areas,... } \\
\text { etc), planting dates, and } \\
\text { elevation }\end{array}$ & $\begin{array}{l}-10-10-10 \\
- \text { Natural based } \\
\text { organic } \\
- \text { Slow release } \\
\text { nitrogen }\end{array}$ & $\begin{array}{l}\text { - Agricultural } \\
\text { limestone }\end{array}$ & $\begin{array}{l}\text { - Straw or hay } \\
\text { - Hydromulch } \\
\text { - Bonded fiber matrix } \\
\text { - Erosion control } \\
\text { matrix }\end{array}$ \\
\hline VA & $\mathrm{N} / \mathrm{A}$ & $\begin{array}{l}\text { - Seed mixtures } \\
\text { provided }\end{array}$ & - $10-20-10$ & $\begin{array}{l}\text { - Agricultural } \\
\text { (2 tons per } \\
\text { acre) }\end{array}$ & $\begin{array}{l}\text { - Straw or hay } \\
\text { - Cellulose fiber } \\
\text { mulch } \\
\text { - Hydromulch } \\
\text { - Bonded fiber matrix } \\
\text { (slopes } 2 \mathrm{H}: 1 \mathrm{~V} \text { ) }\end{array}$ \\
\hline MD & 3 Regions & 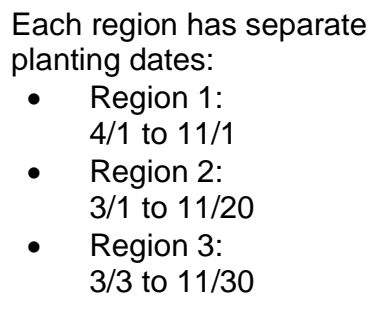 & $\begin{array}{l}\text { - } 10-20-20 \\
\text { - } 10-22-22 \\
\text { - } 18-18-18 \\
\text { - } 18-24-12 \\
\text { - } 19-19-19\end{array}$ & $\begin{array}{l}- \text { Limestone } \\
\text { (composed } \\
\text { of finely } \\
\text { ground } \\
\text { calcitic or } \\
\text { dolomitic } \\
\text { limestone }\end{array}$ & $\begin{array}{l}\text { - Wood Fiber } \\
\text { - Paper Hydraulic } \\
\text { - Wood Fiber + Paper } \\
\text { Hydraulic } \\
\text { - Erosion Control } \\
\text { Blankets } \\
\text { - Straw Mulch }\end{array}$ \\
\hline PA & $\mathrm{N} / \mathrm{A}$ & $\begin{array}{l}\text { - } 13 \text { mixtures provided } \\
\text { - Divided by slope, } \\
\text { banks, drainage, and } \\
\text { mowing tendencies }\end{array}$ & $\begin{array}{l}\text { - } 10-10-20 \\
(1000 \\
\text { pounds per } \\
\text { acre })\end{array}$ & $\begin{array}{l}\text { - Pulverized } \\
\text { agricultural } \\
\text { (6 tons per } \\
\text { acre) }\end{array}$ & $\begin{array}{l}\text { - Straw or hay (3 tons } \\
\text { per acre) } \\
\text { - Wood fiber (1 ton } \\
\text { per acre) }\end{array}$ \\
\hline NC & $\mathrm{N} / \mathrm{A}$ & $\begin{array}{l}\text { - } 6 \text { seed groups provided } \\
\text { - Separated by minimum } \\
\text { pure live seed quantity }\end{array}$ & $\begin{array}{l}\text { - Fertilizer may } \\
\text { contain no } \\
\text { urea }\end{array}$ & $\begin{array}{l}\text { - Agricultural } \\
\text { limestone }\end{array}$ & $\begin{array}{l}\text { - Straw or hay } \\
\text { - Erosion control } \\
\text { blankets }\end{array}$ \\
\hline
\end{tabular}


Table 1, continued

\begin{tabular}{|c|c|c|c|c|c|}
\hline State & State division & Seed mixtures & Fertilizer & Lime & Mulch \\
\hline SC & $\begin{array}{l}\text { Upper Region } \\
\text { Lower Region }\end{array}$ & $\begin{array}{l}\text { - } 14 \text { annual seed types } \\
\text { and } 16 \text { perennial seed } \\
\text { types provided } \\
\text { - Seed classified by } \\
\text { approved sites (slopes, } \\
\text { shoulder, or medians), } \\
\text { planting rage (lbs/acre), } \\
\text { planting location (upper } \\
\text { region vs. lower region), } \\
\text { and planting dates } \\
\text { (identified by month) }\end{array}$ & $\begin{array}{l}\text { - Granular } \\
\text { (slow-release) }\end{array}$ & $\begin{array}{l}\text { - Granular } \\
\text { Agricultural } \\
\text { - Fast Acting } \\
\text { (Liquid or } \\
\text { Dry) }\end{array}$ & $\begin{array}{l}\text { - Straw or Hay } \\
\text { - Wood chip NOT } \\
\text { acceptable }\end{array}$ \\
\hline NY & N/A & $\begin{array}{l}\text { - } 6 \text { mixtures provided } \\
\text { - Divided by application } \\
\text { types (shaded areas, } \\
\text { gravel, sand...etc.) }\end{array}$ & $\begin{array}{l}\text {-5-10-10 (600 } \\
\text { pounds per } \\
\text { acre) }\end{array}$ & $\begin{array}{l}\text { - Limestone } \\
\text { (Rate } \\
\text { determined } \\
\text { by soil test) }\end{array}$ & $\begin{array}{l}\text { - Wood Chips } \\
\text { - Wood Fiber } \\
\text { Cellulose } \\
\text { - Gravel, Stone, or } \\
\text { Slag } \\
\text { - Hay or Straw } \\
\text { - Jute Twisted Yarn } \\
\text { - Excelsior Wood } \\
\text { Fiber Mats } \\
\text { - Compost } \\
\text { - Straw or Coconut } \\
\text { Fiber }\end{array}$ \\
\hline WVDEP & $\begin{array}{ll}\text { 3 Regions } \\
\text { - } \quad \text { Western } \\
\text { Plateau } \\
\text { - } \quad \text { Ridge and } \\
\text { Valley } \\
\quad \text { Region } \\
\text { - } \quad \text { Mountains }\end{array}$ & $\begin{array}{l}\text { - } 29 \text { mixtures provided } \\
\text { - General permanent and } \\
\text { temporary mixtures } \\
\text { - categorized by types of } \\
\text { maintenance required, } \\
\text { planting dates, and } \\
\text { recommended } \\
\text { application sites }\end{array}$ & $\begin{array}{l}\text { - Granular } \\
\text { (slow-release } \\
\text { 10-20-10) }\end{array}$ & $\begin{array}{l}\text { - Granular } \\
\text { Agricultural }\end{array}$ & $\begin{array}{l}\text { - Straw or Hay } \\
\text { - Wood chip } \\
\text { acceptable on } \\
\text { slopes greater than } \\
\text { or equal to } 2: 1\end{array}$ \\
\hline WVDOH & $\mathrm{N} / \mathrm{A}$ & $\begin{array}{l}\text { - } 4 \text { Seeding Areas } \\
\text { - General temporary } \\
\text { seed mixture } \\
\text { - Seed mixture for } \\
\text { planting areas B, C, D, } \\
\text { and L }\end{array}$ & - $10-20-10$ & $\begin{array}{l}\text { - Approved or } \\
\text { denied after } \\
\mathrm{pH} \text { test is } \\
\text { performed }\end{array}$ & $\begin{array}{l}\text { - Straw mulch }(1.5 \mathrm{H} \\
: 1 \mathrm{~V} \text { or less }) \\
\text { - Hydraulic } \\
\text { Seeding(1.5H :1V or } \\
\text { greater) } \\
\text { - Wood Chips }\end{array}$ \\
\hline
\end{tabular}

References: ODOH, 2013; KYBMPs; TDOT; VDOT, 2007; VDOT, 2013; VDOTSPEC; MSA 2005a, b, c, d, e; PennDOT 1998; PennDEP 2009; NCDOTa; NCDOTb; NCDOT 2003; NCDOT 2012; SCDOT 2011; NYSDOT 2002; NYDEC 2005; WVDEP 2010; WVDEP 2006a; WVDEP 2006b; WVDOH 2010 
Table 2: Acceptable seed type per state

\begin{tabular}{|c|c|c|c|c|c|c|c|c|c|c|c|}
\hline & WVDEP & WV & $\mathrm{OH}$ & KY & $\mathrm{TN}^{1}$ & VA & MD & $\mathbf{P A}^{2}$ & NC & SC & NY \\
\hline Annual Ryegrass & $T$ & $\mathrm{P}, \mathrm{T}, \mathrm{R} 652(\mathrm{~T})$ & $\mathrm{P}, \mathrm{T}$ & $\mathrm{T}$ & $\mathrm{I}, \mathrm{II}, \mathrm{T}$ & A & $\mathrm{TC}$ & $\mathrm{C}, \mathrm{E}, \mathrm{L}$ & & & $\mathrm{T}$ \\
\hline Barley & & $\mathrm{T}$ & & & & $\mathrm{P}, \mathrm{A}$ & $\mathrm{TC}$ & & & $x$ & \\
\hline Cereal Rye & & $\mathrm{T}$ & & & & & $\mathrm{TC}$ & & & & $T$ \\
\hline Crownvetch & $\mathrm{P}$ & $\mathrm{P}, \mathrm{R} 652(\mathrm{P})$ & $\mathrm{P}$ & $\mathrm{P}$ & III & A & $\mathrm{EC}$ & C & $X$ & & \\
\hline Japanese Millet & $\mathrm{T}$ & $\mathrm{T}, \mathrm{R} 652(\mathrm{~T})$ & & & & & & & $\mathrm{X}$ & $\mathrm{X}$ & \\
\hline Tall Fescue (Kentucky 31) & $\mathrm{P}$ & $\mathrm{P}, \mathrm{R} 652(\mathrm{P})$ & $\mathrm{P}$ & $\mathrm{P}$ & $\mathrm{II}, \mathrm{III}$ & & & & & & \\
\hline Kentucky Bluegrass & $\mathrm{P}$ & $\mathrm{P}, \mathrm{R} 652(\mathrm{P})$ & $\mathrm{P}$ & $\mathrm{P}$ & & $\mathrm{P}$ & $E C, P$ & $\mathrm{~B}$ & $x$ & & \\
\hline Merion bluegrass & $\mathrm{P}$ & $\mathrm{P}, \mathrm{R} 652(\mathrm{P})$ & & & & & & & & & \\
\hline Oats & & $\mathrm{T}$ & & $\mathrm{T}$ & & & TC & & $\mathrm{X}$ & $\mathrm{X}$ & \\
\hline Red fescue & $\mathrm{P}$ & $\mathrm{P}, \mathrm{R} 652(\mathrm{P})$ & & & & & & & & & \\
\hline Weeping lovegrass & $\mathrm{P}$ & $\mathrm{P}, \mathrm{R} 652(\mathrm{P})$ & & & & & TW, EC & & $X$ & $X$ & \\
\hline Wheat & & $\mathrm{T}$ & & $\mathrm{T}$ & & & $\mathrm{TC}$ & & & $x$ & \\
\hline White Dutch Clover & $\mathrm{P}$ & $\mathrm{P}, \mathrm{R} 652(\mathrm{P})$ & & $\mathrm{P}$ & & & & & & & \\
\hline Alfalfa & $\mathrm{P}$ & $\mathrm{R} 652(\mathrm{P})$ & & & & & & & & & \\
\hline Big Bluestem & $\mathrm{P}$ & $\mathrm{R} 652(\mathrm{P})$ & $\mathrm{P}$ & & & & & & $x$ & & $\mathrm{P}$ \\
\hline Birdsfoot Trefoil & $\mathrm{P}$ & $\mathrm{R} 652(\mathrm{P})$ & & & & $A$ & $E C$ & $W$ & $x$ & & $\mathrm{P}$ \\
\hline Clover & $\mathrm{P}$ & $\mathrm{R} 652(\mathrm{P})$ & & & & & & & & & \\
\hline Deertongue & $\mathrm{P}$ & $\mathrm{R} 652(\mathrm{P})$ & & & & & & & & & \\
\hline Eastern Gamagrass & $\mathrm{P}$ & $\mathrm{R} 652(\mathrm{P})$ & & & & & & & & & \\
\hline Field Bromegrass & $T$ & R652(T) & & & & & & & & & \\
\hline Foxtail millet & $T$ & $\mathrm{R} 652(\mathrm{~T})$ & & & $\mathrm{I}, \mathrm{II}, \mathrm{T}$ & $\mathrm{P}, \mathrm{A}$ & TW & & & $x$ & \\
\hline German Millet & $T$ & $\mathrm{R} 652(\mathrm{~T})$ & & & $\mathrm{I}, \mathrm{II}, \mathrm{T}$ & & & & $x$ & $x$ & \\
\hline Hairy Vetch & $T$ & $\mathrm{R} 652(\mathrm{~T})$ & & & & & & & & $x$ & \\
\hline Indiangrass & $\mathrm{P}$ & $\mathrm{R} 652(\mathrm{P})$ & $\mathrm{P}$ & & & & & & $x$ & $x$ & $\mathrm{P}$ \\
\hline Ladino Clover & $\mathrm{P}$ & $\mathrm{R} 652(\mathrm{P})$ & & $\mathrm{P}$ & & & & & & & \\
\hline Little Bluestem & $\mathrm{P}$ & $\mathrm{R} 652(\mathrm{P})$ & $\mathrm{P}$ & & & & & & $x$ & $x$ & $\mathrm{P}$ \\
\hline Orchardgrass & $\mathrm{P}$ & $\mathrm{R} 652(\mathrm{P})$ & & $\mathrm{P}$ & & $\mathrm{P}$ & & & $x$ & & \\
\hline Perennial Pea & $\mathrm{P}$ & $\mathrm{R} 652(\mathrm{P})$ & & & & & & & & & \\
\hline
\end{tabular}


Table 2, continued

\begin{tabular}{|c|c|c|c|c|c|c|c|c|c|c|c|}
\hline & WVDEP & WV & $\mathrm{OH}$ & KY & $\mathrm{TN}^{1}$ & VA & MD & $\mathbf{P A}^{2}$ & NC & SC & NY \\
\hline Perennial Ryegrass & $\mathrm{P}$ & $\mathrm{R} 652(\mathrm{P})$ & $\mathrm{P}$ & $\mathrm{P}, \mathrm{T}$ & & & $E C, P$ & B & & $x$ & $\mathrm{P}, \mathrm{T}$ \\
\hline Perennial Ryegrass Ladino & $\mathrm{P}$ & $\mathrm{R} 652(\mathrm{P})$ & & & & & & & & & \\
\hline Red Clover & & $\mathrm{R} 652(\mathrm{P})$ & & $P$ & & & & & $x$ & & \\
\hline Redtop & $\mathrm{T}, \mathrm{P}$ & $\mathrm{R} 652(\mathrm{P}, \mathrm{T})$ & & $\mathrm{P}$ & III & & & W & & & $P$ \\
\hline Reed Canarygrass 1 & $P$ & $\mathrm{R} 652(\mathrm{P})$ & & & & & EC & & $\mathrm{X}$ & & \\
\hline Serecia Lespedeza & $\mathrm{P}$ & $\mathrm{R} 652(\mathrm{P})$ & & $\mathrm{P}$ & & A & EC & & $\mathrm{X}$ & $\mathrm{X}$ & \\
\hline Sideoats Grama & $P$ & $\mathrm{R} 652(\mathrm{P})$ & $P$ & & & & & & & & $P$ \\
\hline Spring Oats & $\mathrm{T}$ & $\mathrm{R} 652(\mathrm{~T})$ & & & & & & & & & \\
\hline Switchgrass & $P$ & $\mathrm{R} 652(\mathrm{P})$ & $\mathrm{P}$ & $\mathrm{P}$ & & & & & $\mathrm{X}$ & $X$ & $\mathrm{P}$ \\
\hline Timothy & $\mathrm{P}$ & $\mathrm{R} 652(\mathrm{P})$ & & $\mathrm{P}$ & & & & & & & \\
\hline White Clover & $P$ & $\mathrm{R} 652(\mathrm{P})$ & & $\mathrm{P}$ & & & & & $x$ & $X$ & $\mathrm{P}$ \\
\hline Winter Rye & $\mathrm{T}$ & $\mathrm{R} 652(\mathrm{~T})$ & & & & $P, A$ & & & & & $\mathrm{~T}$ \\
\hline Winter Wheat & $\mathrm{T}$ & $\mathrm{R} 652(\mathrm{~T})$ & & & & $\mathrm{P}, \mathrm{A}$ & & & & & \\
\hline Bahiagrass & & & & & & & & & & $\mathrm{X}$ & \\
\hline Barnyard Grass & & & & & & & & & $\mathrm{X}$ & & \\
\hline Bermudagrass & & & & & $\mathrm{I}$ & $\mathrm{P}$ & & & $\mathrm{X}$ & $\mathrm{X}$ & \\
\hline Bermudagrass, hulled & & & & & I, II & & & & & & \\
\hline Bluegrass, Kentucky-Elite & & & & & & $\mathrm{P}$ & & & & & \\
\hline Bluegrass, Roughstaulk & & & & $\mathrm{P}$ & & & EC & & & & \\
\hline Bristly Locust & & & & & & & & & $\mathrm{X}$ & & \\
\hline Smooth Bromegrass & & & & $P$ & III & & & & & & \\
\hline Browntop Millet & & & & & & & & & $\mathrm{X}$ & $X$ & \\
\hline "Cape" American Beach Grass & & & & & & & & & & & $\mathrm{P}$ \\
\hline Carpet grass & & & & & & & & & $\mathrm{X}$ & $X$ & \\
\hline Centipedegrass & & & & & & & & & $\mathrm{X}$ & $\mathrm{X}$ & \\
\hline Chewings Fescue & & & & & & $\mathrm{P}$ & & $B, D$ & & & \\
\hline Crimson Clover & & & & & & & & & & $\mathrm{X}$ & \\
\hline Coastal Panicgrass & & & & & & & & & & $\mathrm{X}$ & $\mathrm{P}$ \\
\hline Downy Sunflower ${ }^{3}$ & & & $P$ & & & & & & & & \\
\hline Dropseed, prairie & & & $\mathrm{P}$ & & & & & & & & \\
\hline Flatpea & & & & & & & EC & & & & \\
\hline
\end{tabular}


Table 2, continued

\begin{tabular}{|c|c|c|c|c|c|c|c|c|c|c|c|}
\hline & WVDEP & WV & $\mathrm{OH}$ & KY & $\mathrm{TN}^{1}$ & VA & MD & $\mathbf{P A}^{2}$ & NC & SC & NY \\
\hline Hard Fescue & & & $P$ & & & $P$ & $\mathrm{EC}$ & L & $x$ & & \\
\hline Italian Ryegrass & & & & & III & & & & & & \\
\hline Kobe Lespedeza & & & & & $X$ & & & & $\mathrm{x}$ & $x$ & \\
\hline Korean Lespedeza & & & & & $\mathrm{X}$ & & & & $\mathrm{x}$ & $\mathrm{X}$ & \\
\hline Lehmann's Lovegrass & & & & & & & TW, EC & & & & \\
\hline Lovegrass & & & & & & A & & & & & \\
\hline New England Aster & & & $\mathrm{P}$ & & & & & & & & \\
\hline Ox-eye Sunfower & & & $P$ & & & & & & & & \\
\hline Partridge Pea & & & & $P$ & & & & & & & \\
\hline Pearl Millet & & & & & & & & & & $\mathrm{X}$ & \\
\hline Pensacaol bahiagrass & & & & & $\mathrm{I}, \mathrm{II}$ & & & & $x$ & & \\
\hline Prairie Dock & & & $P$ & & & & & & & & \\
\hline Purple Coneflower & & & $\mathrm{P}$ & & & & & & & & \\
\hline Red Fescue, Creeping & & & $P$ & & & $\mathrm{P}$ & & $B, D, L$ & $x$ & & $\mathrm{P}$ \\
\hline Rye Grain & & & & & & & & & $x$ & $x$ & \\
\hline Saltmeadow Cordgrass & & & & & & & & & & & $\mathrm{P}$ \\
\hline Sheep's Fescue & & & & & & $\mathrm{P}$ & $\mathrm{EC}$ & & & & \\
\hline Shrub Lespedeza & & & & & & & & & $x$ & & \\
\hline Sundangrass & & & & & $\mathrm{I}, \mathrm{II}, \mathrm{T}$ & & & & $x$ & $x$ & \\
\hline Tall fescue & & & & $\mathrm{P}, \mathrm{T}$ & & $\mathrm{P}$ & $E C, P$ & $\mathrm{D}, \mathrm{W}$ & $\mathrm{X}$ & $\mathrm{x}$ & $\mathrm{P}$ \\
\hline Virginia Wild Rye & & & & & & & & & & $x$ & \\
\hline Whorled Rosinweed & & & $P$ & & & & & & & & \\
\hline Wildflower mixture & & & & & & & & & & & $\mathrm{P}$ \\
\hline Yellow Blossom Sweet Clover & & & & $\mathrm{P}$ & & & & & $\mathrm{X}$ & & \\
\hline Zoysia & & & & & & & & & $\mathrm{X}$ & & \\
\hline
\end{tabular}

Notes: $P=$ permanent, $T=$ temporary, $X=a c c e p t a b l e, ~ A=a d d i t i v e, T W=$ temporary warm season, $T C=$ temporary cool season, $E C=$ temporary erosion control

${ }^{1} \mathrm{I}, \mathrm{II}$, and III refer three regions of the state

${ }_{3}^{2} \mathrm{~A}, \mathrm{~B}, \mathrm{C}, \mathrm{D}, \mathrm{E}, \mathrm{L}$, and W specify the 7 Formulas (mixtures)

${ }^{3}$ Italics represent a flower species

References: ODOH, 2013; KYBMPs; TDOT; VDOT, 2007; VDOT, 2013; VDOTSPEC; MSA 2005a, b, c, d, e; PennDOT 1998; PennDEP 2009; NCDOTa; NCDOTb; NCDOT 2003; NCDOT 2012; SCDOT 2011; NYSDOT 2002; NYDEC 2005; WVDEP 2010; WVDEP 2006a; WVDEP $2006 \mathrm{~b}$; WVDOH 2010 


\section{Ch. 3 Methods:}

\subsection{Study Site Locations}

Vegetation and site characteristics were measured a 33 field sites. These experimental locations were distributed throughout West Virginia (Figure 1). A description of each site location is presented in the following sections.

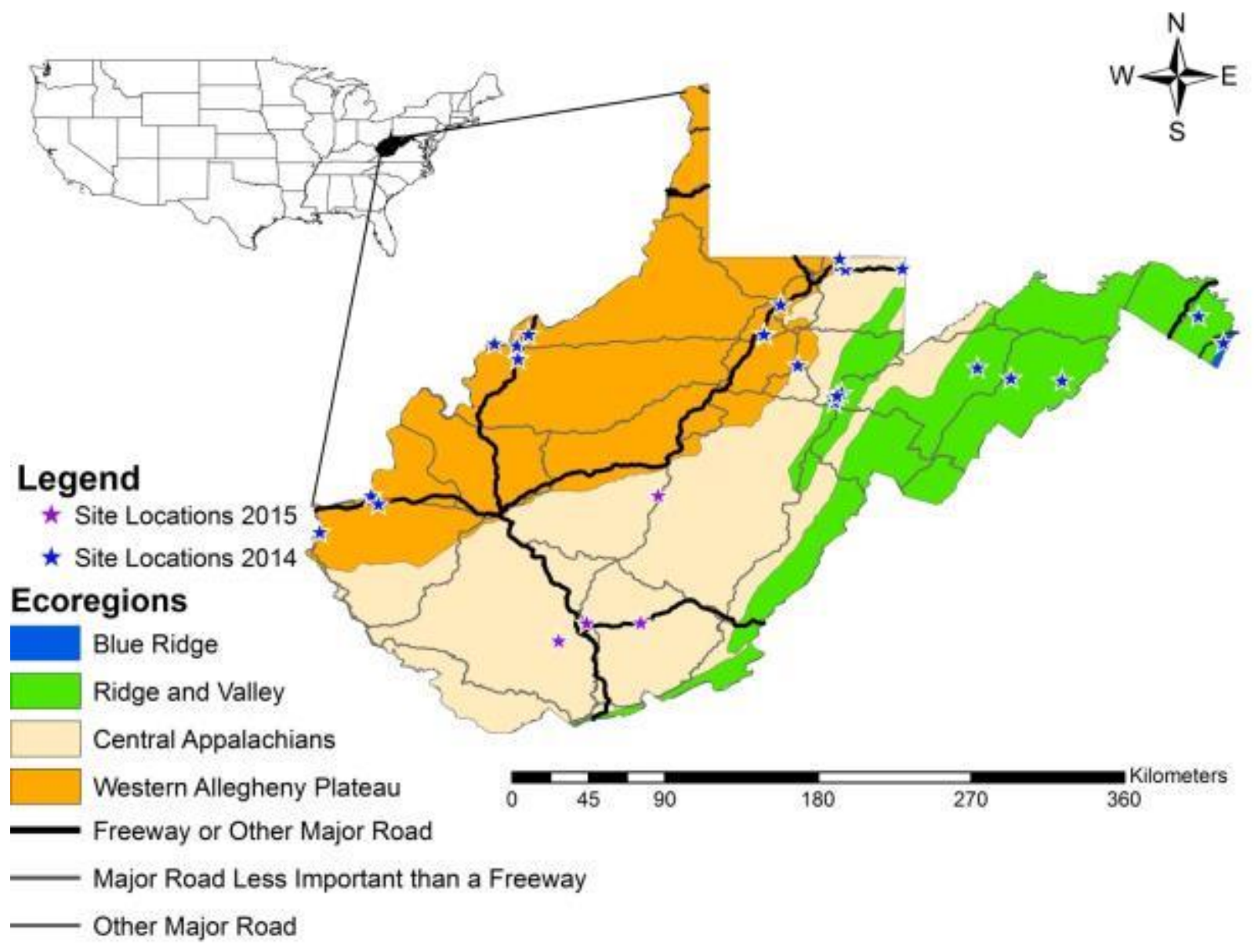

Figure 1: Experimental site locations in West Virginia 


\subsubsection{South Mineral Wells}

The South Mineral Wells site was located off of Interstate 77 exit 170 on West Virginia 14 on the north and south side of the Larry W. Border Memorial Bridge. This site showed good growth; it was primarily made up of crownvetch. This site was broken into two sub-sites: north side (Figure 2) and south side (Figure 3), with five sub-plots on each side. This was done to encompass reclamation of both sides of the bridge.

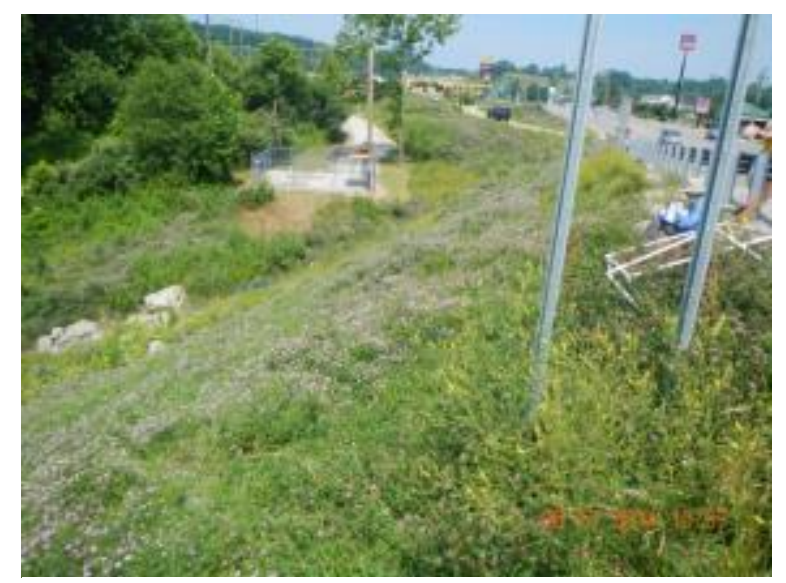

Figure 2: South Mineral Wells south side

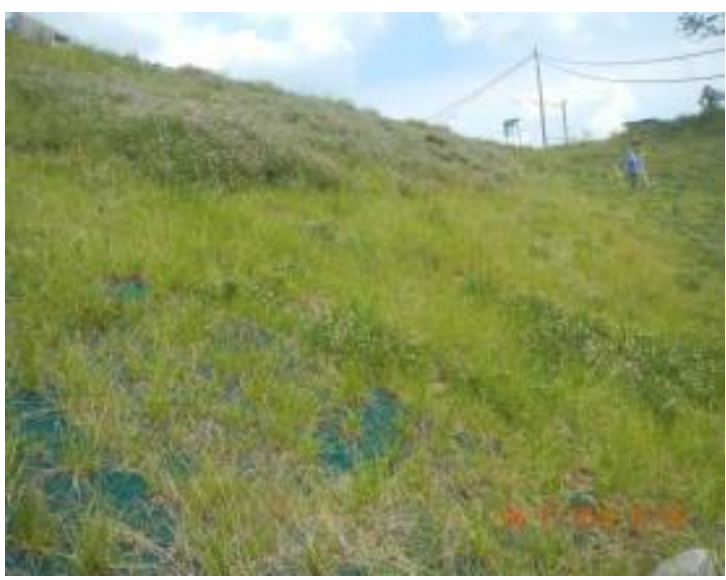

Figure 3: South Mineral Wells north side

\subsubsection{Fairmont Gateway Connector}

The Fairmont Gateway Connector site was located off of Interstate 79 exit 136 between Stoney Road and Pleasant Valley Road (Figure 4). This site had good growth and was frequently mowed. A notable feature of this site was the small stream running through the center that had apparent acid mine drainage.

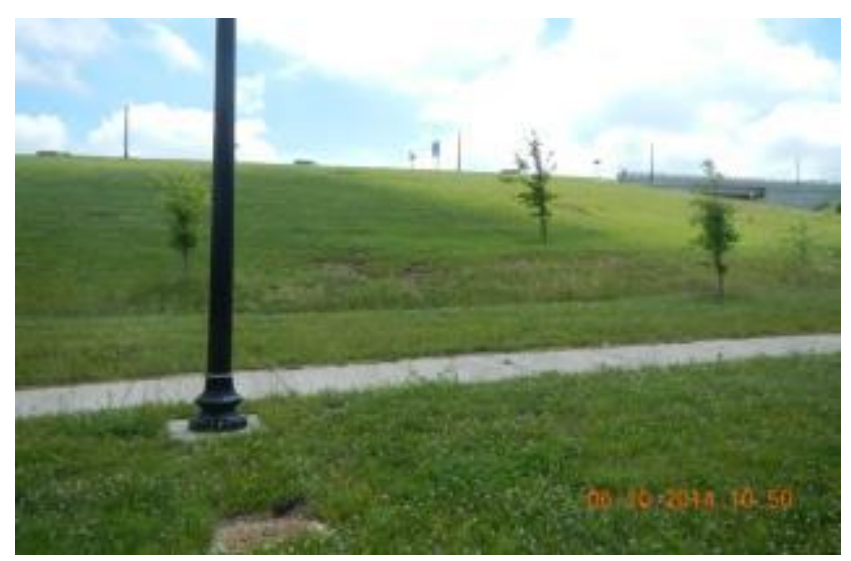

Figure 4: Fairmont Gateway Connector 


\subsubsection{Interchange}

The 47 Interchange site was located off of the West Virginia 47 / Staunton Avenue exit on Rt. 50. The location was approximately 10 acres in size and located at the park and ride parking lot on Staunton Avenue just off of the exit. The slope side of this site was very steep, with predominantly crownvetch cover. The opposite side, parking lot side, was fairly flat with minimal coverage. Also, there were two types of soil on this location. On the steep slope, the soil was of a red shale consistency (Figure 5). On the flat side, there was a yellow shale soil (Figure 6).

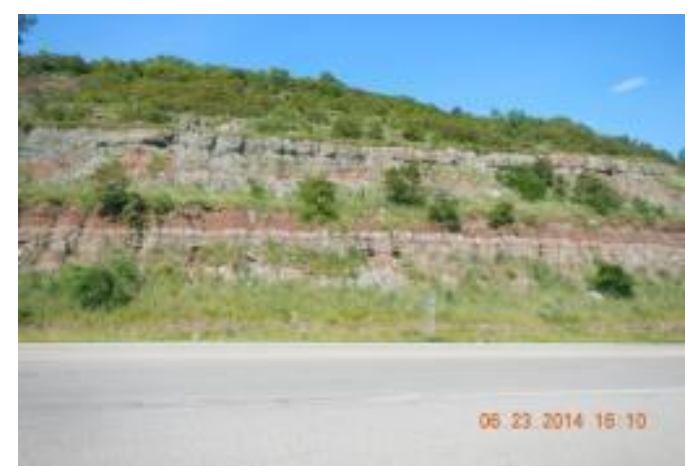

Figure 5: 47 Interchange A

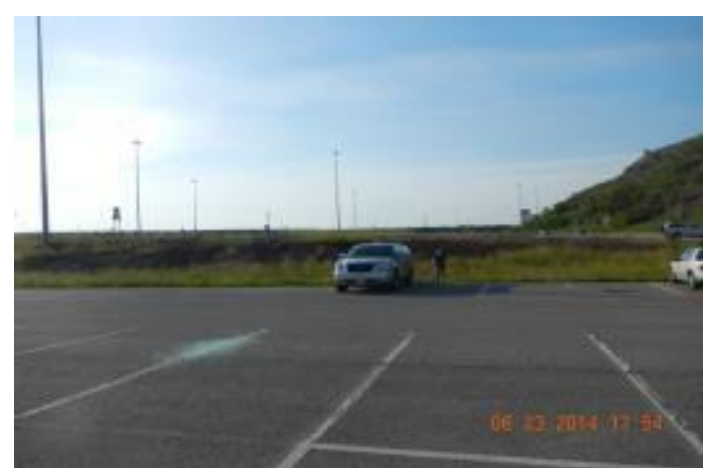

Figure 6: 47 Interchange B

\subsubsection{Blennerhasset}

The Blennerhasset site was on the on ramp to Rt. 50 perpendicular to West Virginia 892. The site location consists of steep walls with large benches that make up the cuts. The soil was composed of red shale and the site had spotty growth (Figure 7).

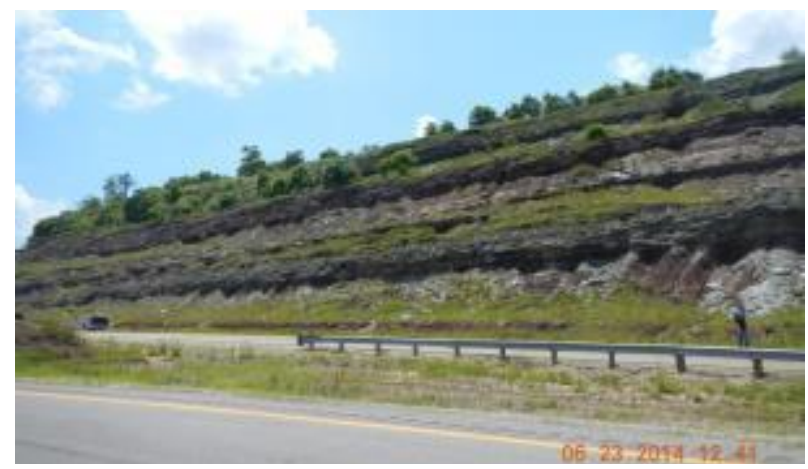

Figure 7: Blennerhasset 


\subsubsection{Emerson Avenue}

The Emerson Avenue site was located on Rt. 2 just off of Interstate 77 exit 179. This was a smaller site on the side of the roadway with good coverage of predominately crownvetch and tall fescue (Figure 8).

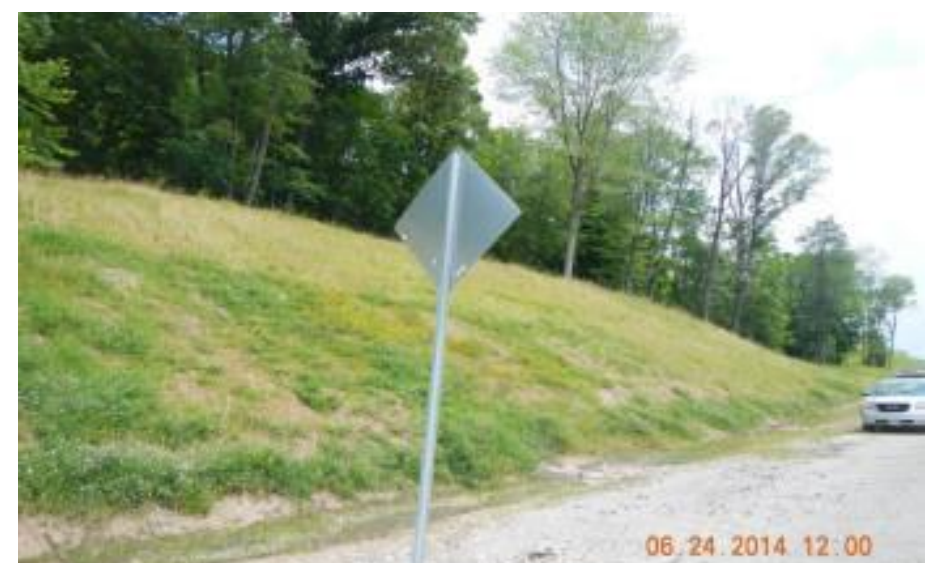

Figure 8: Emerson Avenue

\subsubsection{I68 Median}

The location was on Interstate 68 at the emergency turn around before the Coopers Rock exit. The site had partial to full cover. It also had rocky soil and cinders on the surface (Figure 9).

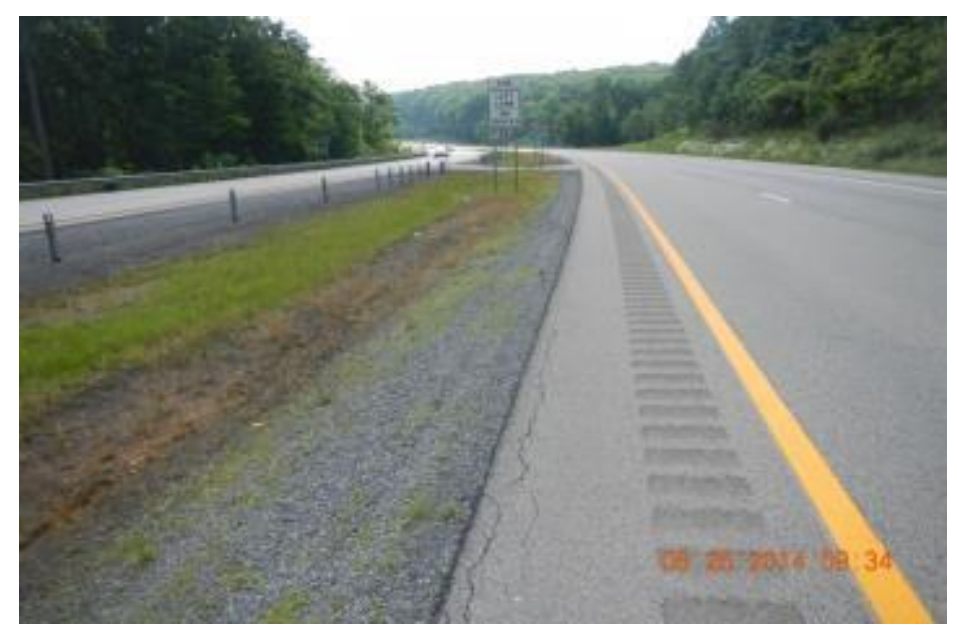

Figure 9: Interstate 68 Median 


\subsubsection{I68 West Virginia Visitor Center}

The WV Visitor Center site was located on the exit ramp to the facility. The site had full cover and was predominantly flat (Figure 10).

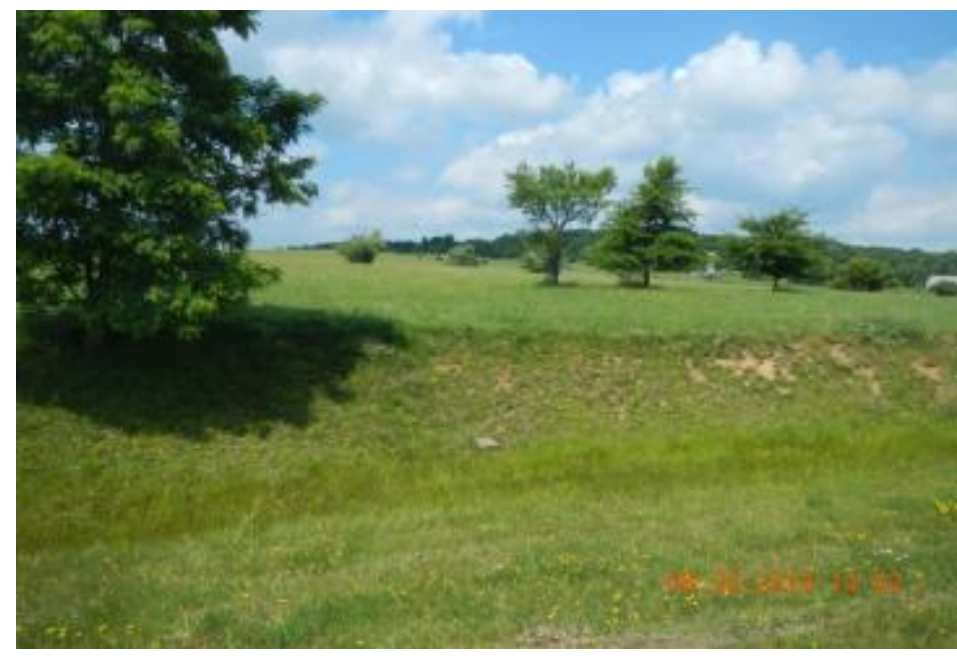

Figure 10: Interstate 68 West Virginia Welcome Center

\subsubsection{Phillipi Bypass}

The Phillipi Bypass site was located on Route 250 just off of Route 119. The site was steeply sloped and covered predominantly with crownvetch (Figure 11).

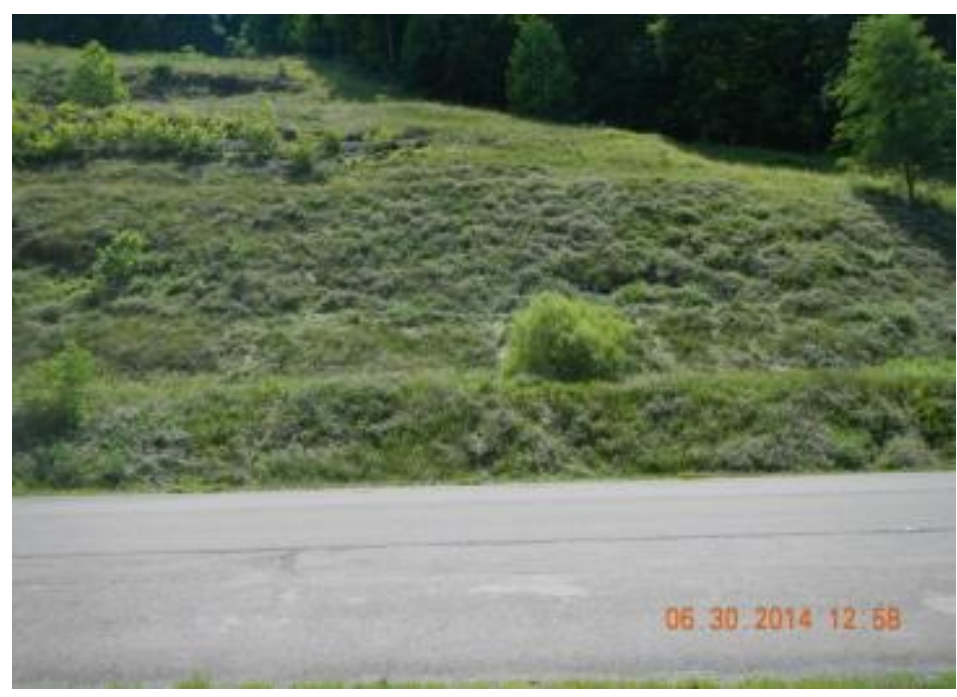

Figure 11: Phillipi Bypass 


\subsubsection{Route 279 Site 1}

The 279 Site 1 was located on Route 279 just east of the Benedum Drive exit. Site 1 was steep in nature and had two separate soil types throughout the site (Figure 12).

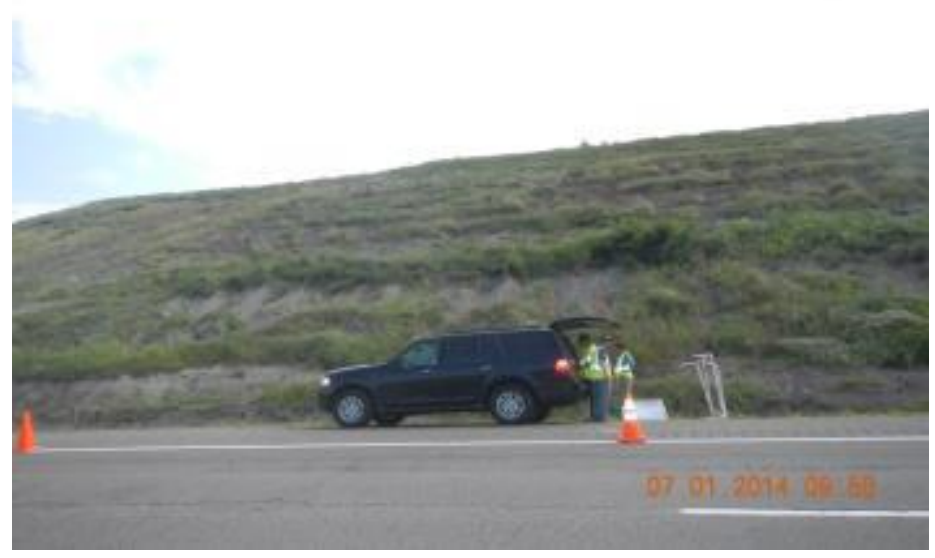

Figure 12: 279 Site 1

\subsubsection{Route 279 Site 2}

The 279 Site 2 was located on Route 279 just west of the Benedum Drive exit. The slope was steep with good cover (Figure 13).

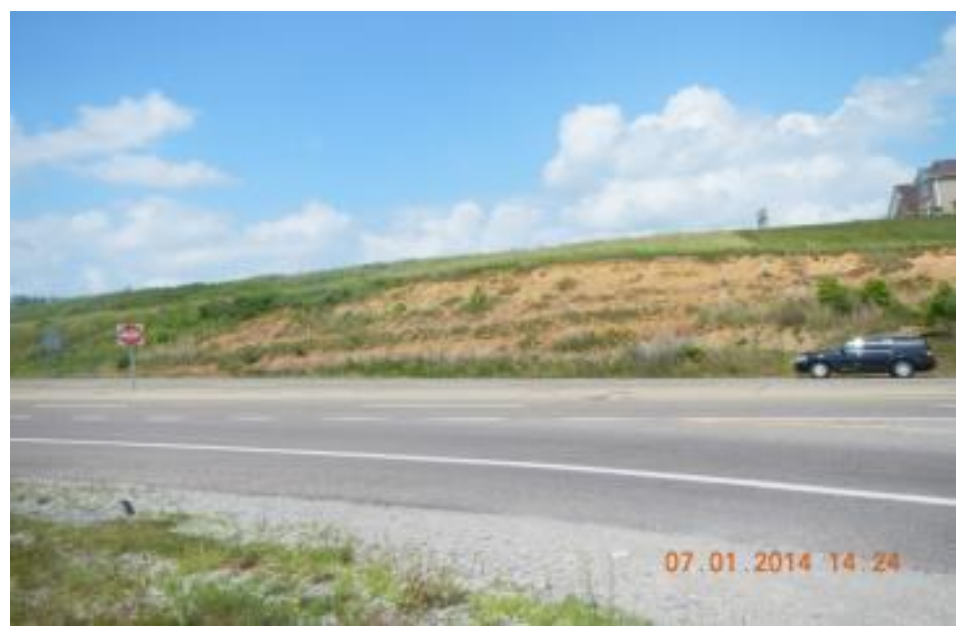

Figure 13: 279 Site 2 


\subsubsection{Mon-Fayette Expressway Site 1}

The Mon-Fayette Expressway Site 1 was located just before the Pennsylvania state line on West Virginia 43. This site had a lush crownvetch cover. The site was steep, but had one bench on the lower part of the slope (Figure 14).

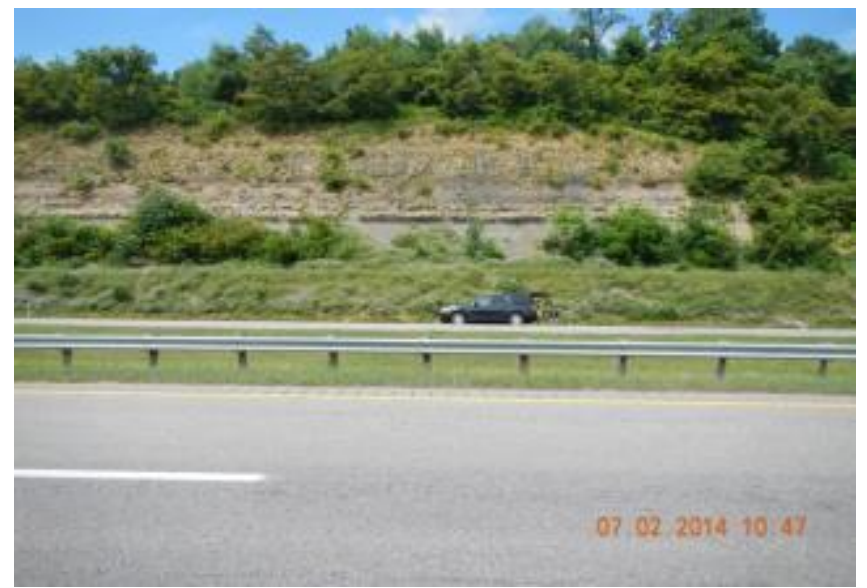

Figure 14: Mon-Fayette Expressway Site 1

\subsubsection{Mon-Fayette Expressway Site 2}

The Mon-Fayette Expressway Site 2 was located just before the Pennsylvania state line on West Virginia 43. This site was predominately gray shale. The site was steep and had one bench on the lower part of the slope (Figure 15).

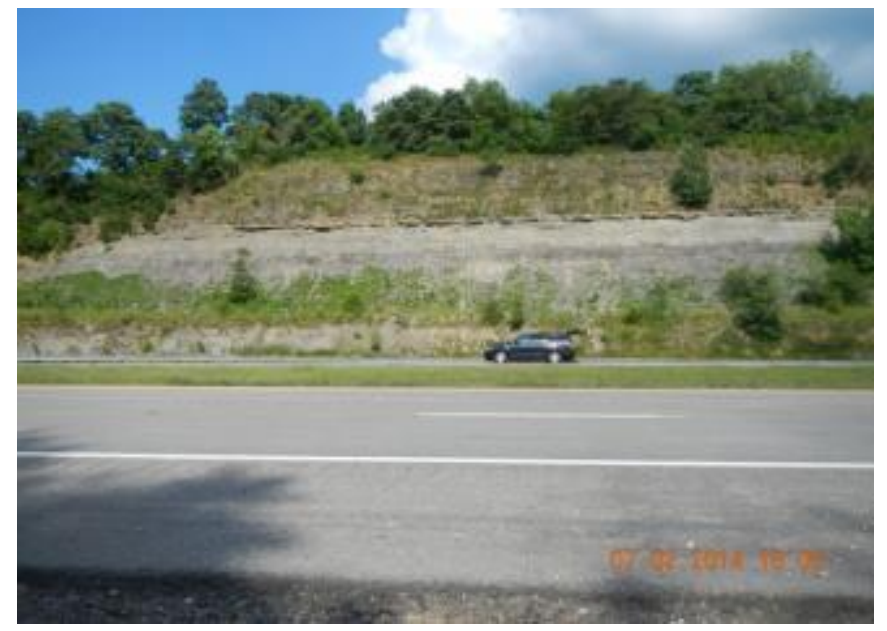

Figure 15: Mon-Fayette Expressway Site 2 


\subsubsection{Corridor H Site 1}

The Corridor H Site 1 was located on U.S. 48 approximately $1 \mathrm{mi} .(1.61 \mathrm{~km})$ from the intersection of 92 and 48 . The site was off of the west bound lane of U.S. 48. This site had minimal coverage and was predominately red and gray shale (Figure 16).

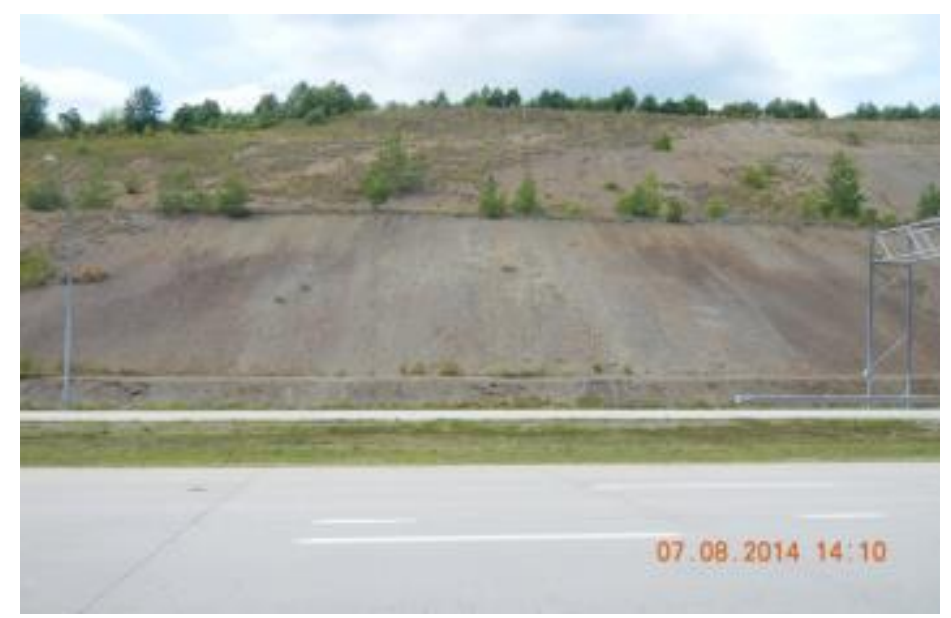

Figure 16: Corridor H Site 1

\subsubsection{Corridor H Median 1}

The Corridor H Median Site was located on U.S. 48 approximately 2500 feet (762 m) from where the corridor currently ends. The site was relatively flat and had good coverage (Figure 17).

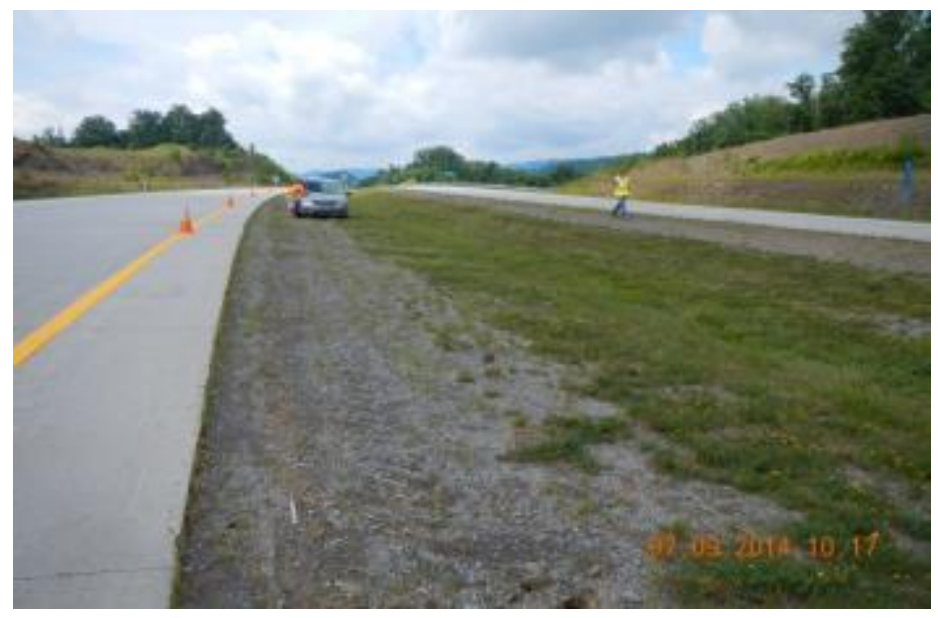

Figure 17: Corridor H Median 1 


\subsubsection{Corridor H Site 2}

The Corridor H Site 2 was located on U.S. 48 approximately 2500 feet $(762 \mathrm{~m})$ from where the corridor currently ends. The site was split into two parts; one subplot on both sides of U.S. 48 (Figure 18 and Figure 19). This site was steep and had moderate coverage by white clover.

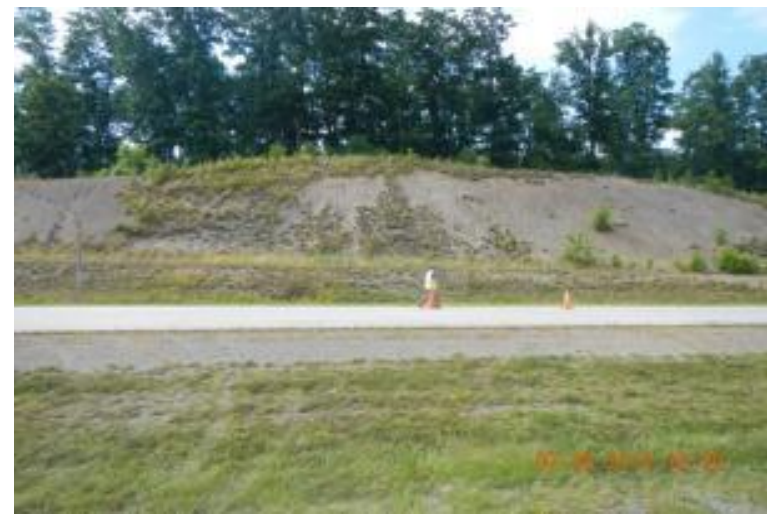

Figure 19: Corridor H Site 2A

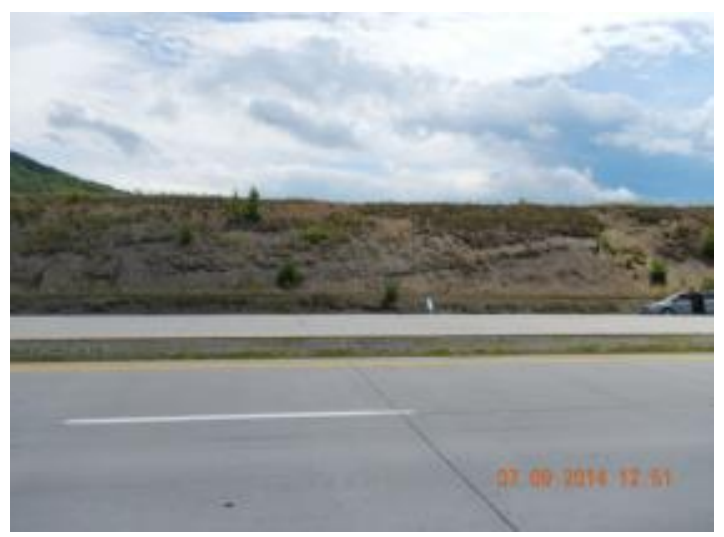

Figure 18: Corridor H Site 2B

\subsubsection{Corridor H Site 3}

The Corridor H Site 3 was located on U.S. 48. This site was steep and had good coverage by crownvetch (Figure 20).

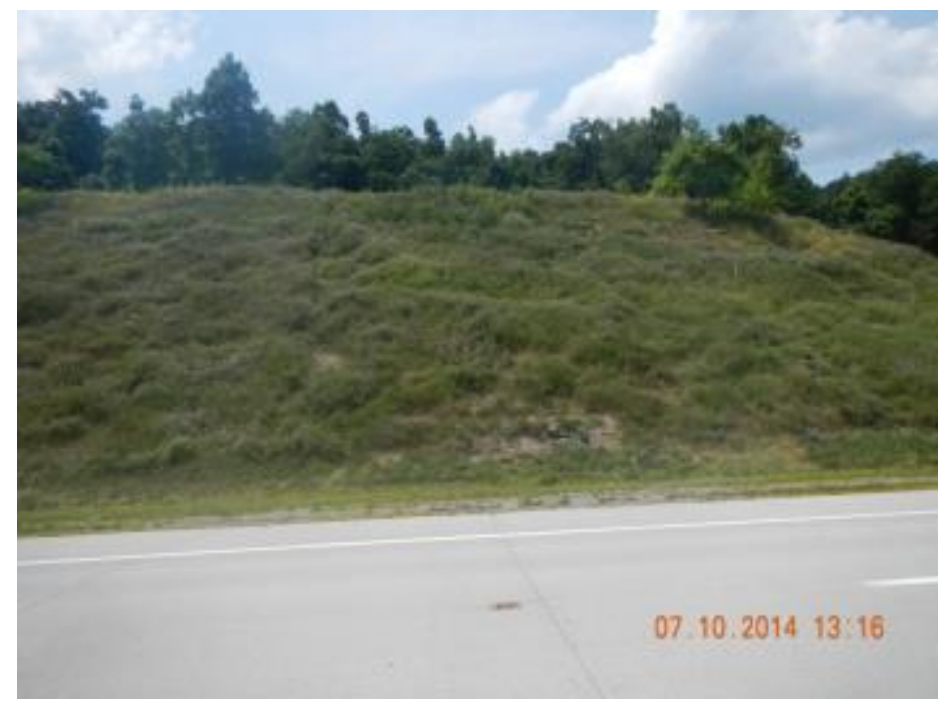

Figure 20: Corridor H Site 3 


\subsubsection{Corridor H Median 2}

The Corridor H Median 2 site was located on U.S. 48. This site was relatively flat and had good coverage by red clover, crownvetch, and annual ryegrass (Figure 21).

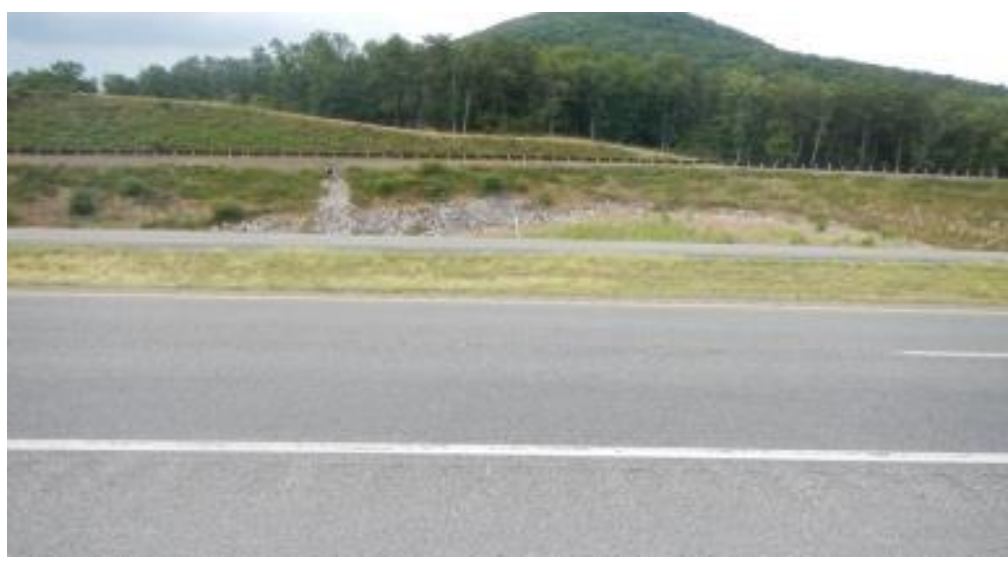

Figure 21: Corridor H Median 2

\subsubsection{Corridor H Site 4}

The Corridor H Site 4 was located on U.S. 48. This site was fairly steep and had minimal coverage. The only notable coverage on either side of the site was blackberry bushes and white pine (Figure 22).

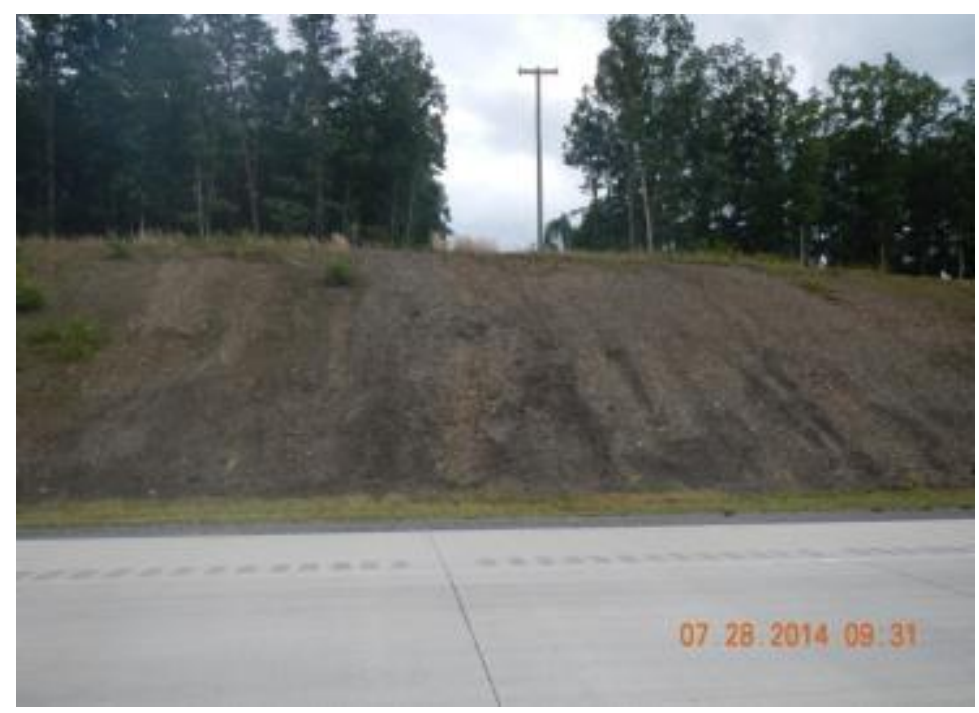

Figure 22: Corridor H Site 4 


\subsubsection{Corridor H Site 5}

The Corridor H Site 5 was located on U.S. 48. This site was steep and had good coverage by predominately sericea lespedeza. Also this site was notably sandy (Figure 23).

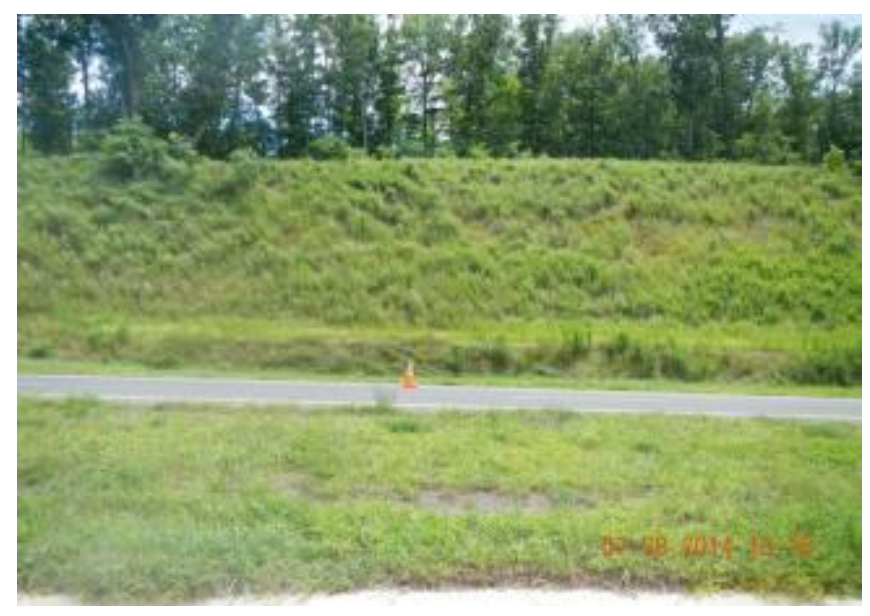

Figure 23: Corridor H Site 5

\subsubsection{Route 9 Site 1}

The Route 9 Site 1 was located on Route 9 by mile marker 70.5 just before the Shenandoah River Bridge. This site was predominately covered by red clover, red fescue, and tall fescue (Figure 24).

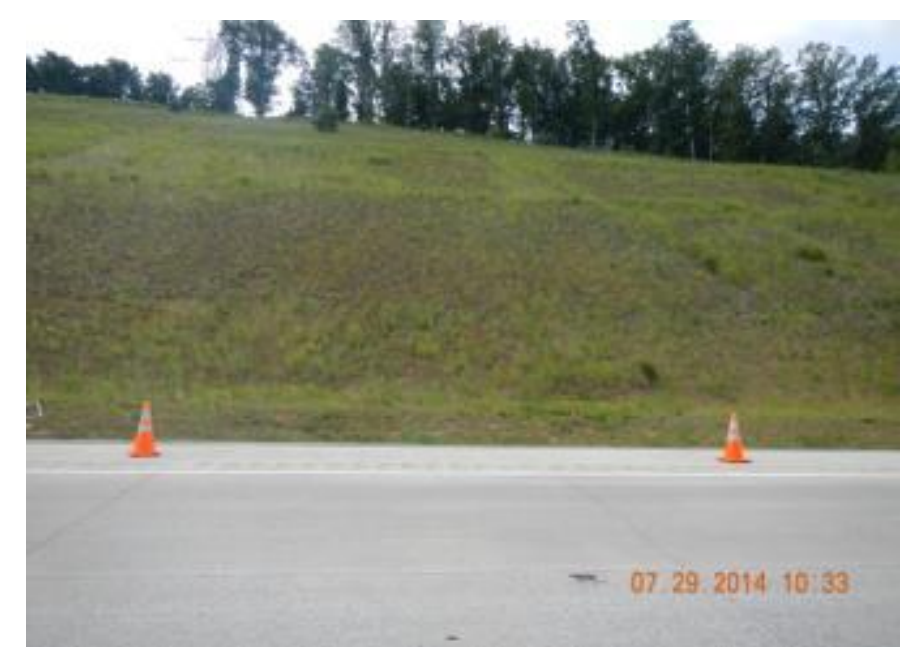

Figure 24: Route 9 Site 1 


\subsubsection{Route 9 Site 2}

The Route 9 Site 2 was located just past the Short Road exit 9/19 westbound on Route 9. This site was composed of serecia lespedeza, tall fescue, and birdsfoot trefoil (Figure 25).

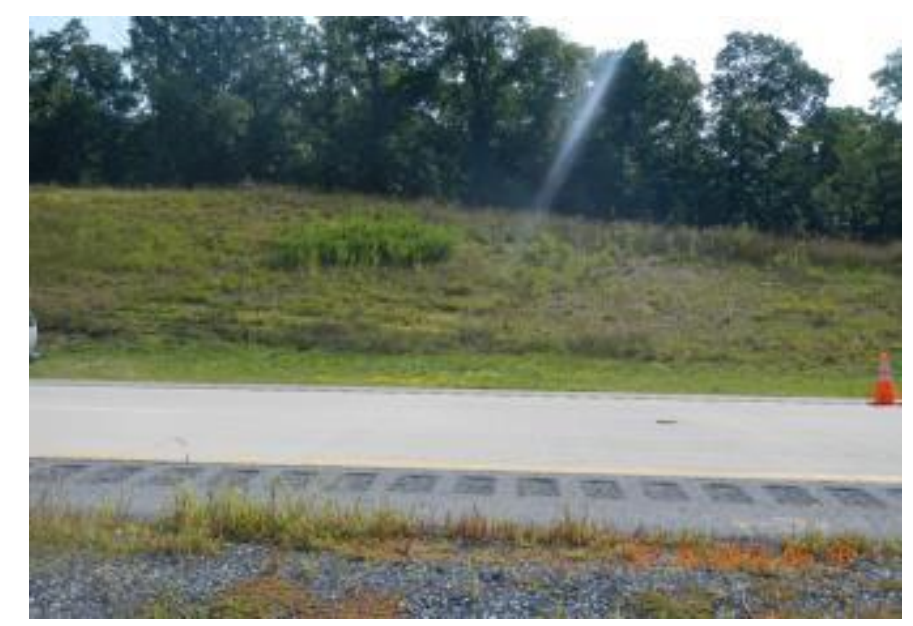

Figure 25: Route 9 Site 2

\subsubsection{Route 193}

The Route 193 site was located on Rt. 193 just before the junction of Rt. 2 . The site was steep and rocky, and composed predominately of red and gray shale with tall fescue and crownvetch vegetation (Figure 26).

\subsubsection{Route}

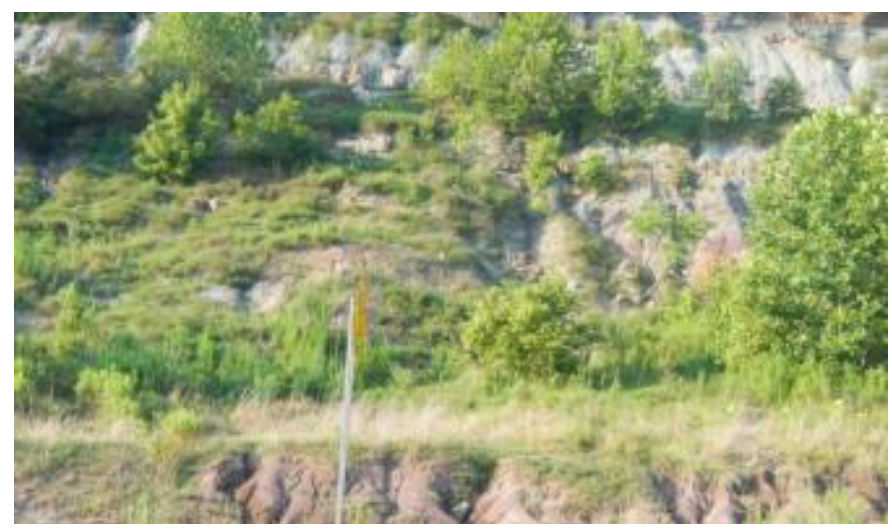

Figure 26: Route 193 
The Route 52 site was located just off of Route 52 near the West Virginia and Kentucky state borders. The site was split into two subsites due to being separated by a roadway as well as two soil compositions. Route 52 A (Figure 27) was the cut slope, and the Route 52 B (Figure 28) was the fill from the steep slope. Both cut and fill slopes had minimal coverage.

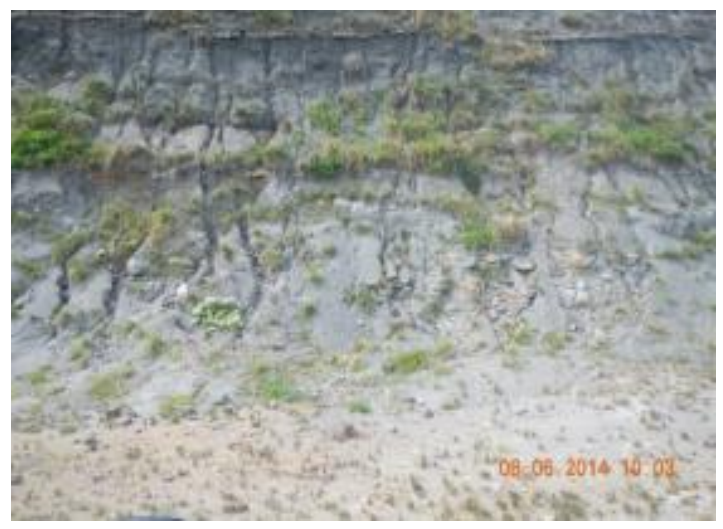

Figure 27: Route $52 \mathrm{~A}$

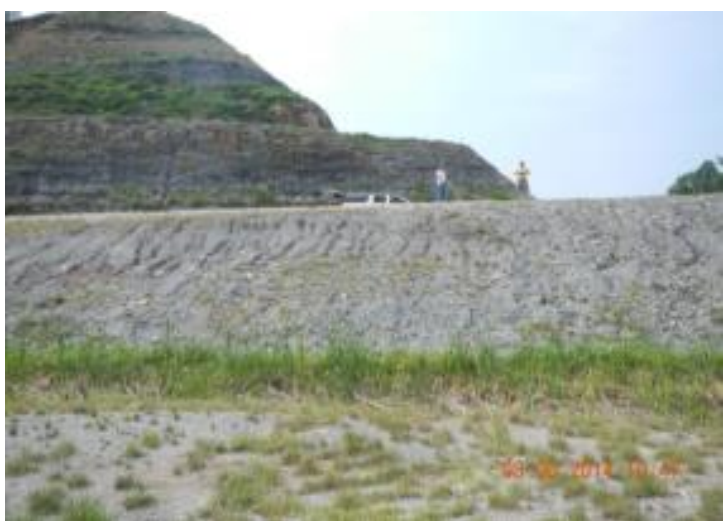

Figure 28: Route 52 B

\subsubsection{Interstate 64}

The Interstate 64 site was located off of Interstate 64 near the park and ride. This site was partially fertilized as a result of the nearby wild flower bed projects. This site had consistently good vegetation throughout (Figure 29).

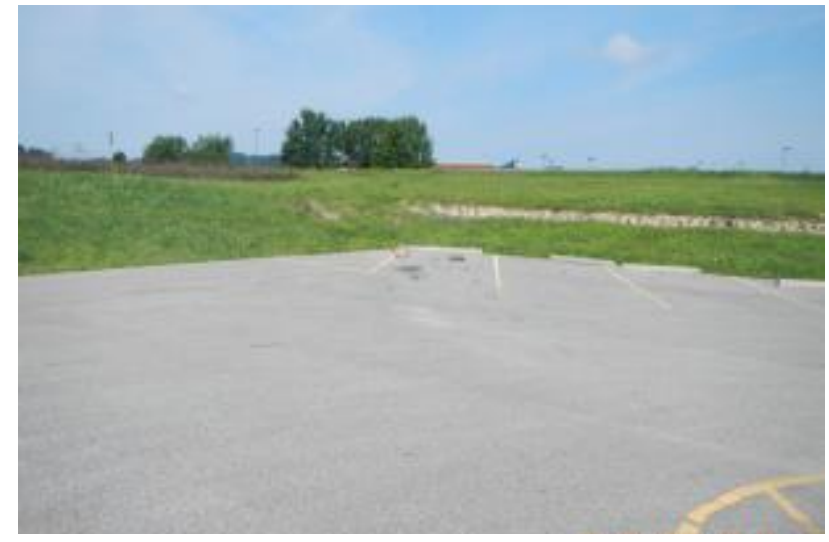

Figure 29: Interstate 64 


\subsubsection{Interstate 64 Beckley}

The Interstate 64 Beckley site was located off of Interstate 64 just past mile marker 142 east bound. This site had a gentle slope, and the site had consistently good vegetation throughout of predominantly crownvetch and tall fescue (Figure 30).

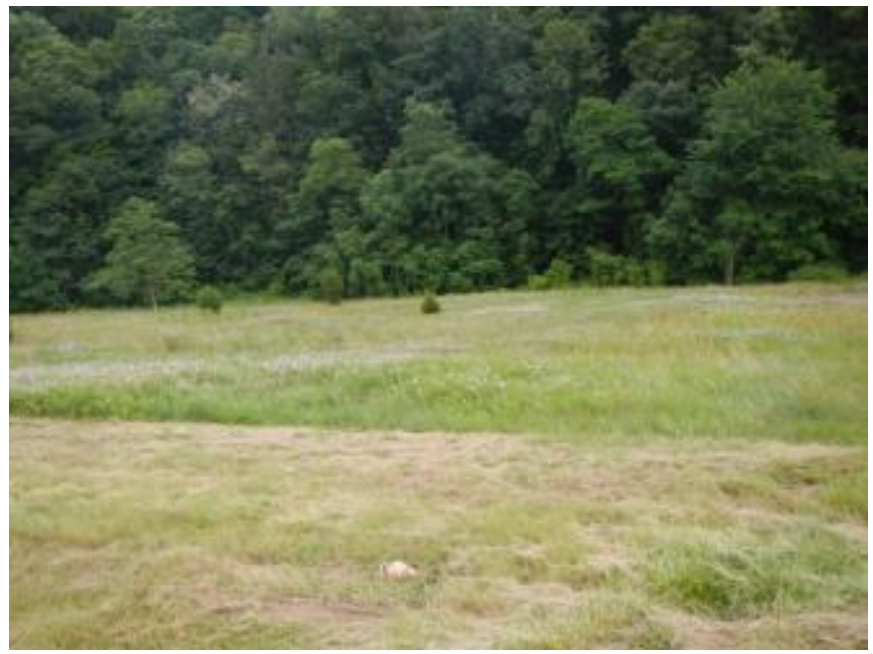

Figure 30: Interstate 64 Beckley

\subsubsection{East Beckley Bypass}

The East Beckley Bypass site was located on the East Beckley Bypass about 0.5 mi (805 m)from the intersection of East Beckley Bypass and Route 41. This site had a steep slope, and the site had consistently good vegetation throughout (Figure 31).

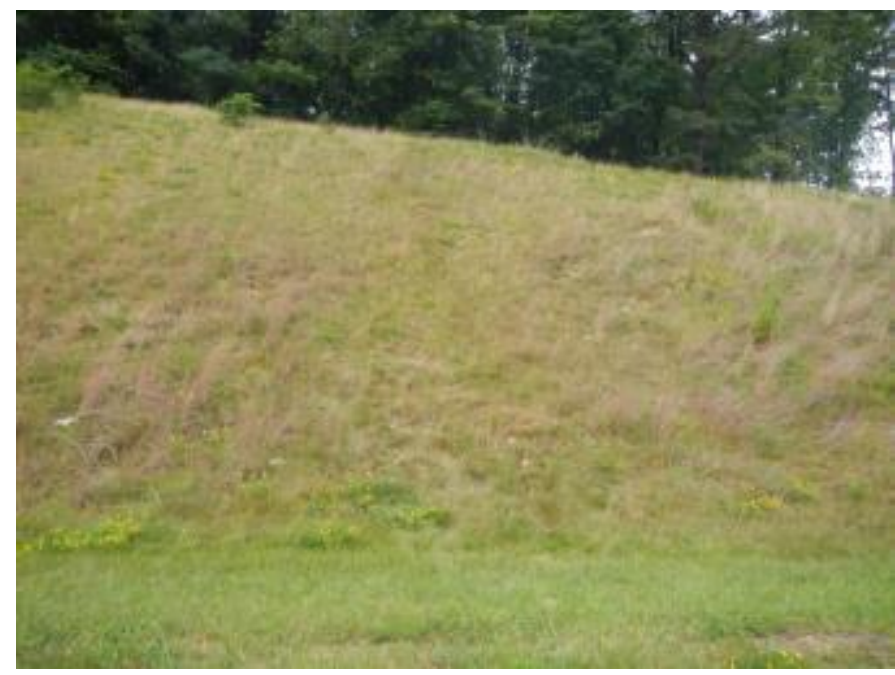

Figure 31: East Beckley Bypass 


\subsubsection{Coalfields Expressway}

The Coalfields Expressway site was located on the new construction of Route 121 Coalfields Expressway. The subsurface for the roadway was completed but there was no pavement. This site had a flat slope, and the site had consistently good vegetation throughout (Figure 32).

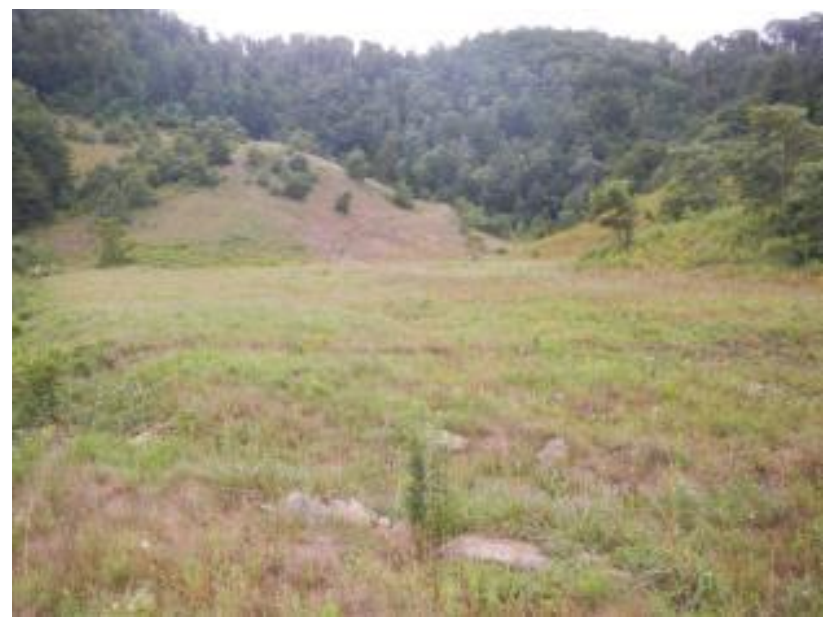

Figure 32: Coalfields Expressway

\subsubsection{Route 19}

The Route 19 site was located off of US Route 19 North at mile marker 55.5. This site had a moderate slope, and the site had consistently good vegetation throughout (Figure 33).

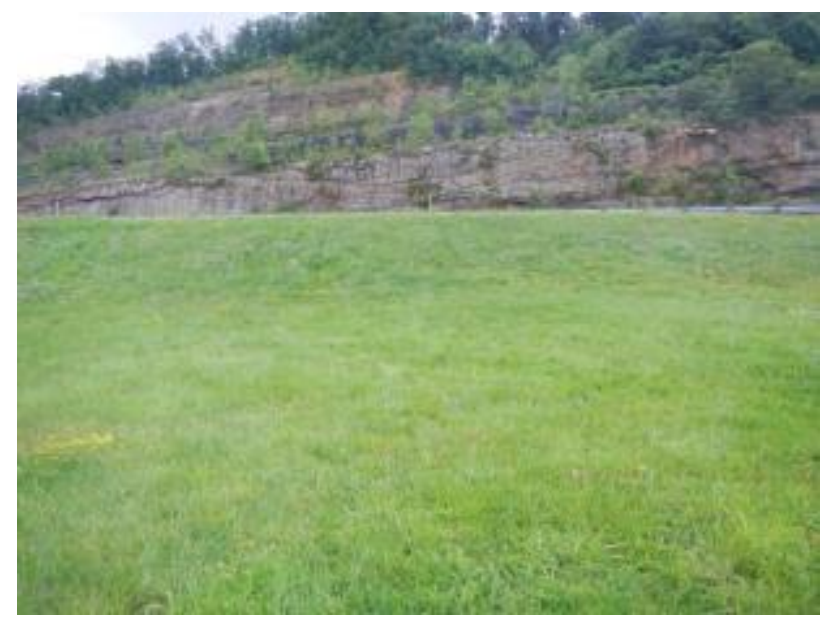

Figure 33: Route 19 


\subsection{Field Methods}

The team started by going through the supply box checklist to ensure that all equipment was available for use. Once on site, the team set up cones along the roadway, filled out the paperwork for the site, labeled the soil sample bags, and unloaded and prepared the equipment.

\subsubsection{Site Specifications}

\subsubsection{Site Location}

The team determined the job site area by marking the four corners with marker flags. The Garmin etrex20 handheld GPS (horizontal error: $\pm 49.21 \mathrm{ft}(15 \mathrm{~m})$, vertical error: $\pm 1312 \mathrm{ft}$ $(400 \mathrm{~m}))$ was used to measure the longitude, latitude, and elevation of each corner. For the general site location, the approximate center of the work area was marked with a waypoint location with the GPS. This gave a general longitude, latitude, and elevation of the entire site.

\subsubsection{Sub-site Locations}

Within each experimental plot, ten random sampling locations were identified using methods adapted from Elzinga et. al. (1998). The method used for random selection is explained below. The process started by picking a number from a randomly generated list to determine the amount of steps to take. The number was chosen by picking a number from 1 to 4 and a number from 1 to 50 . The first number correlates to 4 separate lists of 50 randomly generated numbers. The second number correlates to a number in the randomly generated list of 50 numbers. After selecting the appropriate number, the second hand of a watch was used to select the direction in which to walk. While standing at the approximate center of the work area, one team member would look at the second hand of a watch. The direction that the second hand was pointing in at that instant was the direction that the team member would walk. Using the number selected from the randomly generated list and the direction from the watch, the team would have a completely random location in the work area for each subplot. While two team members determined the randomized site locations, the third team member would stand at the bottom of the slope, allowing full view of the site, and mark on Field Form 1 the approximate 
location of each subplot on a sketch. This was done in order to give an overview of the distribution of subplots as well as aid in locating the subplots during testing in tall vegetation. On some sites this was necessary to locate the subplots because the marker flags were shorter than the vegetation. An example of the field form is presented in Appendix D.

\subsubsection{Vegetation Measurements}

\subsubsection{Portable Point Frame (PPF)}

A portable point frame was used to quantify vegetation cover. Vegetation surveys were completed using a $3.28 \mathrm{ft} \times 3.28 \mathrm{ft}(1 \mathrm{~m}$ by $1 \mathrm{~m})$ portable point frame with 100 equally spaced measurement points following procedures by Calloudon et al. (1996) and Elzinga et al. (1998).The Portable Point Frame (PPF) was placed on the ground with the device pointing downhill (Figure 34). The marker flag that designated the subplot location was placed in the bottom left corner of the device at every subplot to ensure consistency when testing. The device was read by looking down at each intersection of horizontal and vertical lines giving the appearance of a crosshair. If there was vegetation directly beneath the crosshair, then that would be counted as cover and denoted with a "C". If there was no vegetation, only soil, rock, or geotextile then the respective grid mark would be denoted with a "B" for bare. Once all 100 crosshairs were read, the total percent cover and total percent bare was calculated and reported. A "birds-eye view" photo was taken of the plot with the PPF frame (Figure 35). The top of the frame was ensured to be placed on the downhill of the slope to ensure consistency throughout the field testing.

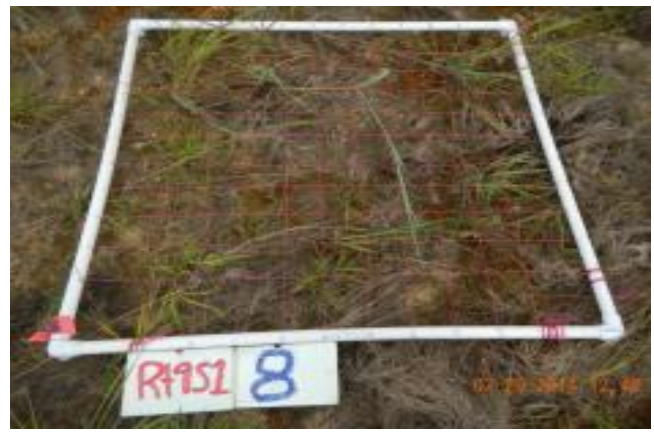

Figure 34: Team evaluating PPF

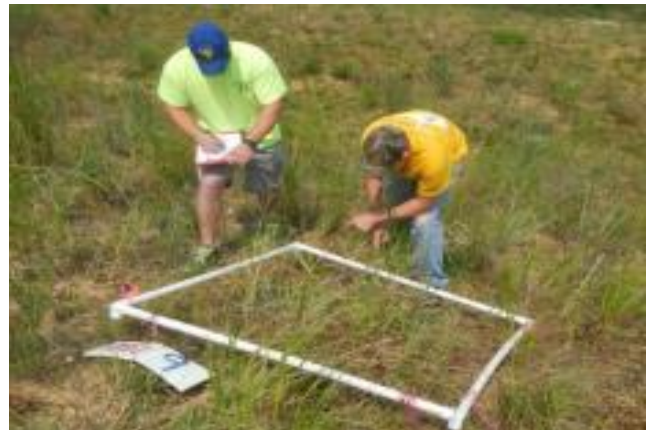

Figure 35: View of PPF in field 


\subsubsection{Biomass}

Stem measurements were obtained at each subsite that was evaluated in the summer of 2014. The four sites evaluated in summer 2015 were not evaluated for stem measurements because it was different growing season. Ten random vegetation species were selected throughout the subsite, vegetation permitting. The stem height and stem diameter of each of the ten pieces of vegetation was measured and reported for evaluating the site. The stem diameter was measured with a set of calipers, and the stem height was measured using a tape measure.

\subsubsection{Physical Site Measurements}

\subsubsection{Elevation Measurements}

Elevation was measured at each subsite using the Garmin etrex 20 handheld GPS and confirmed using topographical maps.

\subsubsection{Slope Measurements}

The slope exposure and the slope steepness were measured using a Suunto A-10 Recreational Compass and Suunto PM-5 Clinometer.

\subsubsection{Compaction Testing}

Compaction tests were performed using the agraTronix Soil Compaction Tester (Streetsboro, OH). The penetrometer complies to and is based on the ASAE S313.3 standard. Methods for performing the compaction test were followed per guidance of the ASAE EP542 code. As one team member placed the penetrometer in the center of the plot and applied steady pressure to the device, the second team member would verbally note the designated depths. At these depths, the operator would report the color of the penetrometer gauge and the number associated to the gauge location. This was recorded by the third team member. Also, the team members would note any inconsistencies in the soil like rockiness or hard clay layers at respective depths. If the penetrometer was stopped short of the full test, the operator would approximate whether clay or rock material caused the penetrometer to reach maximum. 


\subsubsection{Photo Log}

After all testing was completed, pictures were taken of the entire site using a Coolpix AW100 digital GPS camera. The site pictures were composed of eight corner photos that showed a visual of the entire size from the corner flags and one photo of the entire site. Once all of the physical testing was completed, the team would compile the list of photos taken on site in the photo log.

\subsubsection{Soil Testing}

A nutrient soil sample was collected at the random sampling locations following procedures by West Virginia University Soil Testing Laboratory (2007) for lawn and turf. Two 6 in. $(15 \mathrm{~cm})$ deep core samples were taken using a 2.5 in. $(6.4 \mathrm{~cm})$ diameter soil auger at each subplot. The soil samples were thoroughly mixed for each site, and the composite soil samples were analyzed at AgSource Laboratories-Harris (Lincoln, NE) for organic matter (OM), texture (percent sand, silt, and clay), $\mathrm{pH}$, soluble salts, $\mathrm{N}, \mathrm{P}, \mathrm{K}, \mathrm{Mg}, \mathrm{Ca}, \mathrm{S}, \mathrm{Zn}, \mathrm{Mn}, \mathrm{Cu}, \mathrm{Fe}, \mathrm{B}, \mathrm{Cl}, \mathrm{Na}$, and electrical conductivity (EC) (NCR, 1988).

\subsection{Data Analysis}

\subsubsection{Percent Cover}

As previously mentioned, a portable point frame was used to quantify vegetation cover. The data collected using the PPF was input into excel, and the mean vegetation cover was calculated for each site to determine a location's average percent cover. After percent cover was measured, four cover classes (CC) were defined using the average percent cover of each site and is further discussed. Consideration of the $70 \%$ cover needed for permit release was implemented into the resulting cover classes: CC I (0-50\%), CC II (50-70\%), CC III (70-90\%), and CC IV (90-100\%).

\subsubsection{Distribution of Species}

Percent cover by species was determined for each site using the PPF photos taken in the field. The PPF photos were particularly useful because the PPF frame consisted of a 100 
point grid which was used to determine percent cover of the site. This same 100 point grid was valuable in determining percent cover by species because at each point the species present was marked. The marking of the species was performed using the Adobe Photoshop count tool. With this tool, each species was labeled, marked, and tallied. Each individual category was marked and added the number of points for each category. By using the PPF photo, there were 100 points; therefore, the total of each species was the percent cover by species.

\subsubsection{Statistical Analysis}

Simple linear regression was the first method employed to evaluate the factors affecting vegetative cover. The dependent variable, vegetative cover, was compared to all of the independent variables that were tested. After performing the simple regressions of each of the independent variables against the dependent variables, multilinear regression was employed.

Forward selection, a form of multilinear stepwise regression was used to evaluate the data collected from the field testing (Montgomery et. al., 2006). To perform the multilinear forward regression, the following equation was used:

$$
(\text { Yield })=I \text { Coefficient }+P 1+P 2+\cdots+P n
$$

Where $\mathrm{I}=$ Intercept and $\mathrm{P}=$ Parameter.

This method of statistical analysis was selected to allow for an evaluation of multiple independent variables compared to the dependent variable. Also, from the previous calculations from the simple linear regression, the most relatable independent variables were already known; thereby allowing for confirmation of previous results. The variables used in the regression can be seen in Table 3. 
Table 3: Parameters compared against percent cover for multilinear regression

\begin{tabular}{|c|c|}
\hline Percent Cover & $\mathrm{pH}$ \\
\hline Percent Clay & Percent Sand \\
\hline Percent Silt & Percent Organic Matter \\
\hline Nitrogen Content & Phosphorus Content \\
\hline Potassium Content & Soluble Salts \\
\hline Aspect & Slope \\
\hline Cation Exchange Capacity & Elevation \\
\hline
\end{tabular}

To confirm that the forward selection was correct, backward elimination was also used to evaluate the parameters in comparison to the percent cover. With backward elimination, all of the parameters are included in the initial model, and the parameter with the least correlation is then removed based on $p$-value $(\alpha=0.05)$. The model is rerun following the same process until all of the remaining parameters are considered to have a positive correlation (Montgomery et. al., 2006).

\subsubsection{Wilcoxin Tests}

Wilcoxin Tests were used to determine the relationship between all of the variables assessed in the field. This second analysis was used to confirm and further test the observed data to determine differences in factors among cover classes. 


\section{Ch. 4 Results and Discussion}

\subsection{Vegetation}

\subsubsection{Percent Cover}

There was a relatively equal distribution of the field sites among the defined cover classes, and mean vegetation cover included a large range (Figure 36). Ten of the 33 locations had excellent cover (>90\%), eight of the sites had acceptable cover (70\% - 90\%), seven of the sites had poor cover (50\% - 70\%), and eight sites had bad cover (0\% - 50\%). The three median locations were located between acceptable and poor cover $(51.5 \%-83.8 \%)$. The poorest performing locations were steep with exposed shale. The area of exposed rock was not removed in the calculations. Therefore, the percent cover calculated for permit release may be greater than the values calculated in this study.

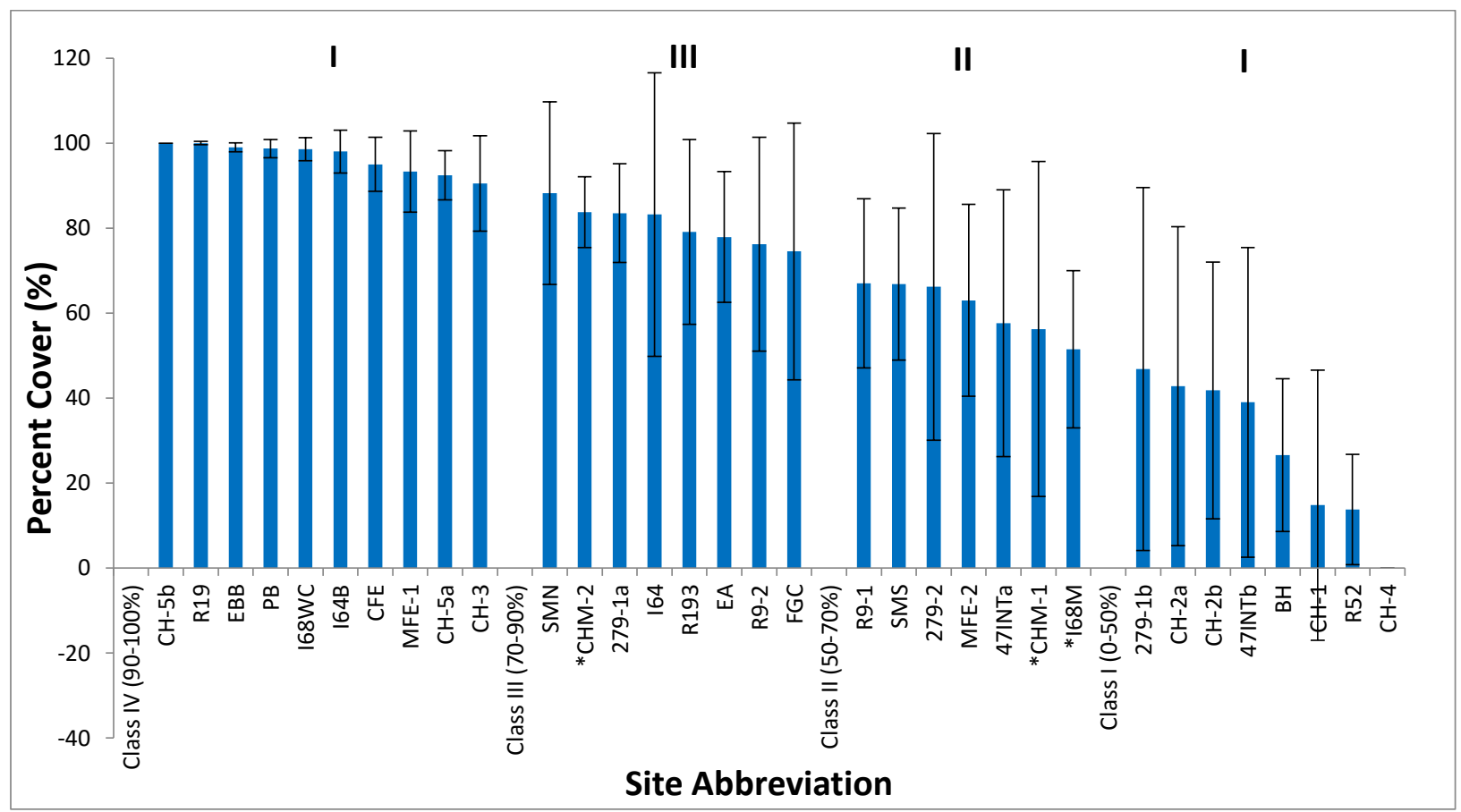

Figure 36: Mean vegetation cover defining cover class (I-IV) for each field site. Error bars denote standard deviation. I (0-50\%), II (50-70\%), III (70-90\%), IV (90-100\%); *indicates a median site. 
The 18 sites defined by greater than $70 \%$ mean cover were dominated by tall fescue (Festuca arundinacea) and Crownvetch (Coronilla varia L.) (>65\% for 13 of the 18 plots), and species richness was generally low (2-6, Table 4). White clover (Trifolium repens), red clover (Trifolium pretense), and sericea lespedeza (Lespedeza cunata) were also substantially represented among these locations. The sites represented by CC I and II (<70\% mean cover) were also dominated by tall fescue, but crownvetch was only present at five sites. White clover, red fescue (Festuca rubra L.), weeping lovegrass (Ergrostis curvula [Schrad.] Nees), serecia lespedeza, birdsfoot trefoil (Lotus corniculatus), and coltsfoot (Tussilago farfara) were also substantially represented among these locations. Table 4 identifies the species that were observed throughout the field studies. 
Table 4: Species distribution among plants for each study site, divided by cover class (I: 0-50\%, II: 50-70\%, III: 70-90\%, IV: $\mathbf{9 0 - 1 0 0 \% ) ~}$

\begin{tabular}{|c|c|c|c|c|c|c|c|c|c|c|c|c|c|c|c|c|c|c|}
\hline & \multicolumn{10}{|c|}{ CCIV } & \multicolumn{8}{|c|}{ CC III } \\
\hline & $\mathrm{CH}-5 \mathrm{~b}$ & R19 & EBB & PB & I68WC & MFE-1 & I64B & CFE & CH-5a & $\mathrm{CH}-3$ & SMN & $\mathrm{CHM}^{-2^{\mathrm{b}}}$ & $279-1 A$ & 164 & R193 & EA & R9-2 & FGC \\
\hline Tall fescue ${ }^{a}$ & 73 & - & 55 & 24 & 64 & 26 & 62 & 54 & 18 & 10 & 4 & 96 & 25 & 74 & 22 & 38 & 72 & 44 \\
\hline Crownvetch $^{\mathrm{a}}$ & 14 & 5 & - & 70 & 13 & 71 & 23 & 8 & 14 & 86 & 80 & 1 & 70 & 3 & 69 & 29 & - & - \\
\hline White clover ${ }^{a}$ & - & 1 & 12 & - & 1 & - & - & 6 & - & 3 & 8 & 2 & - & 14 & - & 7 & - & 38 \\
\hline Annual ryegrass ${ }^{a}$ & - & 71 & - & 3 & - & - & - & - & 8 & - & - & - & - & - & - & - & - & - \\
\hline Red Fescue & - & - & - & - & - & - & - & - & - & - & - & - & - & - & - & - & - & - \\
\hline Weeping lovegrass $^{a}$ & - & - & 19 & - & - & - & - & 1 & - & - & - & - & - & - & - & - & - & - \\
\hline Serecia lespedeza & 13 & - & - & - & - & - & - & - & 57 & - & - & - & - & - & - & - & 14 & - \\
\hline Birdsfoot trefoil & - & 6 & 11 & - & 5 & 1 & - & - & - & 1 & - & - & - & - & - & 3 & - & 4 \\
\hline Red clover & - & 11 & 1 & - & - & - & - & 2 & - & - & 3 & - & - & 6 & - & 17 & 1 & 9 \\
\hline Coltsfoot & - & - & - & - & - & - & - & - & - & - & - & - & - & - & - & - & - & - \\
\hline Buckhorn plantain & - & 4 & - & - & 1 & - & - & - & - & - & - & - & - & 1 & - & 2 & - & 2 \\
\hline Daisy & - & - & - & - & - & - & 5 & 1 & - & - & - & - & - & - & - & - & - & - \\
\hline \multirow[t]{3}{*}{ Other ${ }^{c}$} & - & 1 & 2 & 2 & 15 & 2 & 8 & 28 & - & - & 4 & 1 & - & 2 & 8 & 5 & 12 & 2 \\
\hline & \multicolumn{10}{|c|}{ CC II } & \multicolumn{8}{|c|}{$\mathrm{CCI}$} \\
\hline & R9-1 & SMS & $279-2$ & & VFE-2 & 47INTa & $\mathrm{CHM}^{\mathrm{b}}{ }^{\mathrm{b}}$ & $168 M^{b}$ & & & 279-1B & $\mathrm{CH}-2 \mathrm{a}$ & $\mathrm{CH}-2 \mathrm{~b}$ & 47INTb & BH & $\mathrm{CH}-1$ & R52 & $\mathrm{CH}-4$ \\
\hline Tall fescue ${ }^{a}$ & 50 & 44 & 38 & & 46 & 49 & 70 & 90 & & & 12 & 48 & 66 & 85 & 97 & 26 & 88 & - \\
\hline Crownvetch $^{\mathrm{a}}$ & - & 3 & - & & 8 & - & - & - & & & 71 & - & - & 2 & - & - & 11 & - \\
\hline White clover ${ }^{a}$ & 6 & 25 & 1 & & - & - & 26 & 8 & & & - & 1 & 26 & 10 & - & - & - & - \\
\hline Annual ryegrass ${ }^{a}$ & 1 & 8 & - & & - & 5 & - & - & & & - & - & - & - & 1 & - & - & - \\
\hline Red fescue $\mathrm{a}^{\mathrm{a}}$ & 35 & - & - & & - & - & - & - & & & - & - & - & - & - & - & - & - \\
\hline Weeping lovegrass $^{a}$ & - & - & 36 & & 2 & - & - & - & & & - & 7 & - & - & - & 48 & - & - \\
\hline Serecia Lespedeza & - & - & - & & - & - & - & - & & & - & - & - & - & - & - & - & - \\
\hline Birdsfoot trefoil & - & - & - & & - & 22 & 4 & - & & & - & - & - & - & - & - & - & - \\
\hline Red clover & - & - & 1 & & - & 24 & - & - & & & - & - & 8 & - & - & - & - & - \\
\hline Coltsfoot & - & - & - & & 34 & - & - & - & & & - & - & - & - & - & 25 & - & - \\
\hline Buckhorn plantain & - & 4 & - & & - & - & - & - & & & - & - & - & - & - & - & - & - \\
\hline Daisy & - & & - & & 1 & - & - & - & & & 14 & - & - & - & - & - & - & - \\
\hline Other ${ }^{c}$ & 4 & 6 & 24 & & 9 & - & - & 2 & & & 3 & 36 & - & 2 & 1 & - & 1 & - \\
\hline
\end{tabular}


Tall fescue was observed at 32 sites and 186 sub-sites. The rest of the observed species can be seen in Table 5. All four cover classes were dominant by tall fescue. The results can be seen in Table 6. When considering the most dominant species at median sites, tall fescue was the most dominant observation. The results are presented in Table 7.

Table 5: Most dominant species

\begin{tabular}{|c|c|c|}
\hline Species & $\begin{array}{c}\text { Number of Sites Observed At } \\
\text { (Total 33) }\end{array}$ & $\begin{array}{c}\text { Number of Subsites Observed At } \\
\text { (Total 253) }\end{array}$ \\
\hline Tall Fescue & 32 & 186 \\
\hline Crownvetch & 20 & 99 \\
\hline White Clover & 18 & 50 \\
\hline Red Clover & 13 & 44 \\
\hline Birdsfoot Trefoil & 9 & 30 \\
\hline Annual Ryegrass & 9 & 27 \\
\hline Buckhorn Plantain & 7 & 25 \\
\hline
\end{tabular}


Table 6: Species occurrence per cover class

\begin{tabular}{|c|c|c|}
\hline \multicolumn{3}{|c|}{ Class IV (90-100\%) } \\
\hline Species & Number of Sites Observed At (Total 10) & Number of Subsites Observed At (Total 90) \\
\hline Tall Fesce & 10 & 64 \\
\hline Crownvetch & 10 & 58 \\
\hline Annual Ryegrass & 4 & 18 \\
\hline Birdsfoot Trefoil & 5 & 15 \\
\hline White Clover & 5 & 15 \\
\hline Red Clover & 4 & 15 \\
\hline Buckhorn Plantain & 2 & 14 \\
\hline \multicolumn{3}{|c|}{ Class III (70-90\%) } \\
\hline Species & Number of Sites Observed At (Total 8) & Number of Subsites Observed At (Total 65) \\
\hline Tall Fesce & 8 & 52 \\
\hline Crownvetch & 6 & 33 \\
\hline White Clover & 5 & 21 \\
\hline Red Clover & 5 & 19 \\
\hline Buckhorn Plantain & 4 & 10 \\
\hline \multicolumn{3}{|c|}{ Class II (50-70\%) } \\
\hline Species & Number of Sites Observed At (Total 7) & Number of Subsites Observed At (Total 48) \\
\hline Tall Fesce & 7 & 36 \\
\hline White Clover & 5 & 11 \\
\hline Red Clover & 3 & 9 \\
\hline Annual Ryegrass & 3 & 7 \\
\hline Red Fescue & 1 & 7 \\
\hline Birdsfoot Trefoil & 2 & 6 \\
\hline \multicolumn{3}{|c|}{ Class I (0-50\%) } \\
\hline Species & Number of Sites Observed At (Total 8) & Number of Subsites Observed At (Total 50) \\
\hline Tall Fesce & 7 & 34 \\
\hline Crownvetch & 3 & 6 \\
\hline White Clover & 3 & 3 \\
\hline Moss & 1 & 2 \\
\hline Daisy & 1 & 2 \\
\hline
\end{tabular}

Table 7: Species occurrence per median site

\begin{tabular}{|c|c|c|}
\hline Species & Number of Sites Observed At (Total 3) & Number of Subsites Observed At (Total 12) \\
\hline Tall Fescue & 3 & 12 \\
\hline White Clover & 3 & 4 \\
\hline Birdsfoot Trefoil & 1 & 2 \\
\hline Crownvetch & 1 & 1 \\
\hline
\end{tabular}

\subsubsection{Biomass}

Figure 37 presents the average stem height of each site within the respective cover class. Although there is a reduction in average stem height from the highest percent cover to the lowest, there are large inconsistencies throughout the table. The average stem diameter is presented in Figure 38 and shows minimal difference throughout the cover classes. The 
inconsistencies presented in the graphs are attributed to improper mowing. Because of these inconsistencies due to mowing, these data was not included in the statistical review. For erosion control effectiveness and the health of the vegetation establishment, a more consistent mowing schedule should be implemented. Although cool season grasses can tolerate close mowing, to promote the growth of native vegetation, vegetation should be mowed no shorter than 6 in, and mowing should not be conducted during times of drought or when soil conditions are soft or saturated (Salon and Miller 2012).

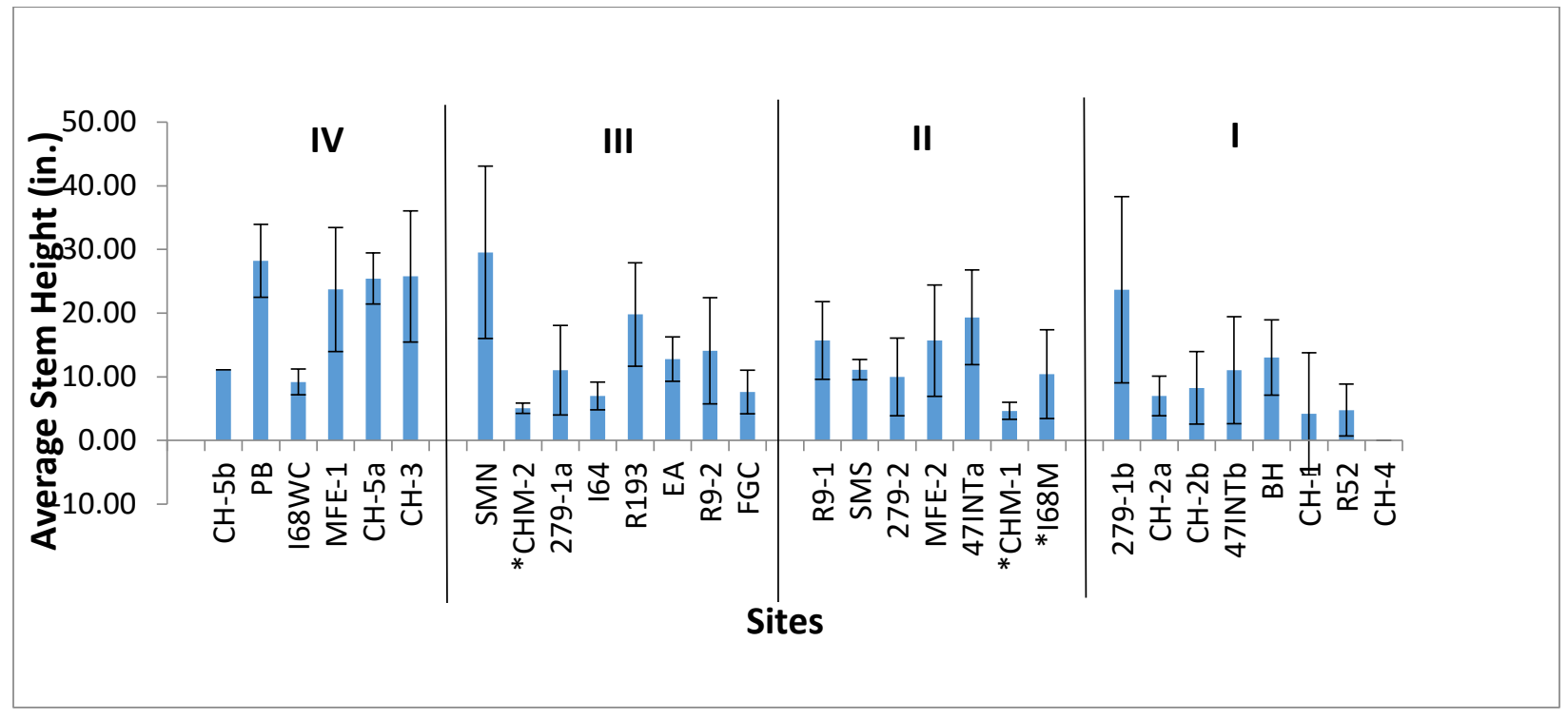

Figure 37: Average stem height per each site divided by cover class

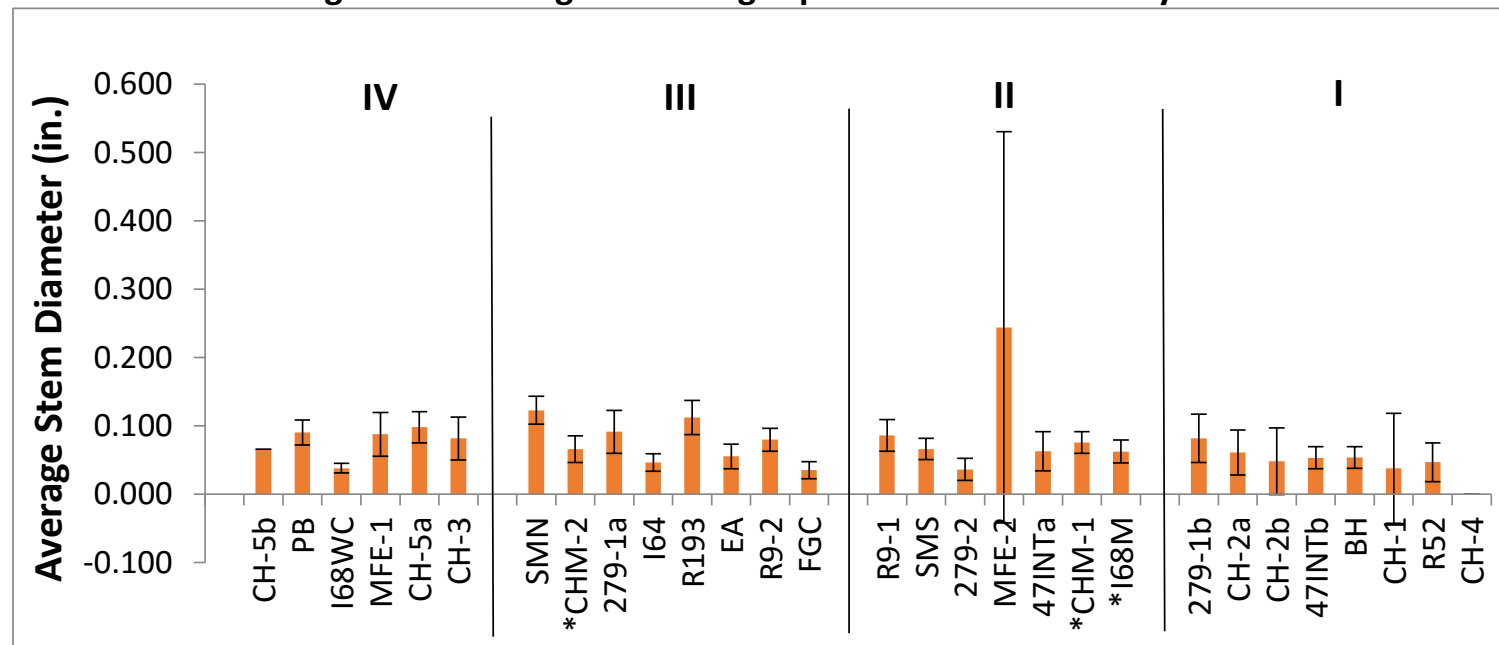

Sites

Figure 38: Average stem diameter per each site divided by cover class 


\subsection{Soils}

Statistical results indicated that high levels of soluble salts were present in locations defined by poor cover (Table 8). There was a strong negative correlation between soluble salts and mean vegetation cover $(r=0.69)$. Half of the sites defined as CC I had soluble salt values greater than a relative critical value of $0.60 \mathrm{mmhos} / \mathrm{cm}$ (AgSource 2006), and an additional site $(\mathrm{CH}-2 \mathrm{a}) \mathrm{had}$ a soluble salt value of $0.59 \mathrm{mmhos} / \mathrm{cm}$, approaching this critical level. The three sites with the lowest mean vegetation cover values of cover class II (47INTa, CHMD1, I68MD) also had elevated soluble salt values. Sites 47INTa, CHMD1, and I68MD had soluble salt values of $1.04,0.77$, and $1.15 \mathrm{mmhos} / \mathrm{cm}$, respectively. In contrast, CC IV sites did not approach the critical value (Table 8).

There were also significant differences in nitrogen when evaluated among cover class. The sites classified as the best performing vegetation cover (CC IV) had the largest concentration of $\mathrm{N}(3-17 \mathrm{mg} / \mathrm{kg})$. Nitrogen was the only macronutrient for which statistical differences were identified among cover class. However, statistical differences were determined for concentrations of $\mathrm{Mn}, \mathrm{Cu}$, and $\mathrm{B}$ (Table 8).

Statistical differences were determined among cover classes for the variable percent clay. Percent clay levels of soils in CC IV were generally less than the soils of CC II and III (Table 8). No other differences in texture were determined. Soil textures of CC I, II and IV were primarily sandy loam and loam. Soil textures of CC III were primarily loam.

Acidic soils were expected in these disturbed sites. However, soil pH ranged from 4 to 9.7, and no linear correlations were identified among cover classes (Table 8). Rather, vegetation cover increased as the $\mathrm{pH}$ approached the optimal range of 6.0 to 7.0 (Salon and Miller, 2012) (Figure 39). As such, $\mathrm{pH}$ levels ranged from 5.2 to 8.4 for sites with vegetation cover greater than the $70 \%$ target value. Two locations resulted $\mathrm{pH}$ values less than $5.0(\mathrm{CH} 2-$ $\mathrm{a}=4.8$, and $\mathrm{CH} 1=4)$. As expected, these two sites were characterized as $\mathrm{CC} \mathrm{I}$. Seventeen of the sites had $\mathrm{pH}$ values greater than 7 , also outside of optimal range. Nine of these alkaline sites 
were classified as CC I and II. The most recently seeded site, South Mineral Wells (SMS and SMN) was seeded within one year of sampling and had elevated $\mathrm{pH}$ values. SMS and SMN had soil $\mathrm{pH}$ values of 8.0 and 8.4 .

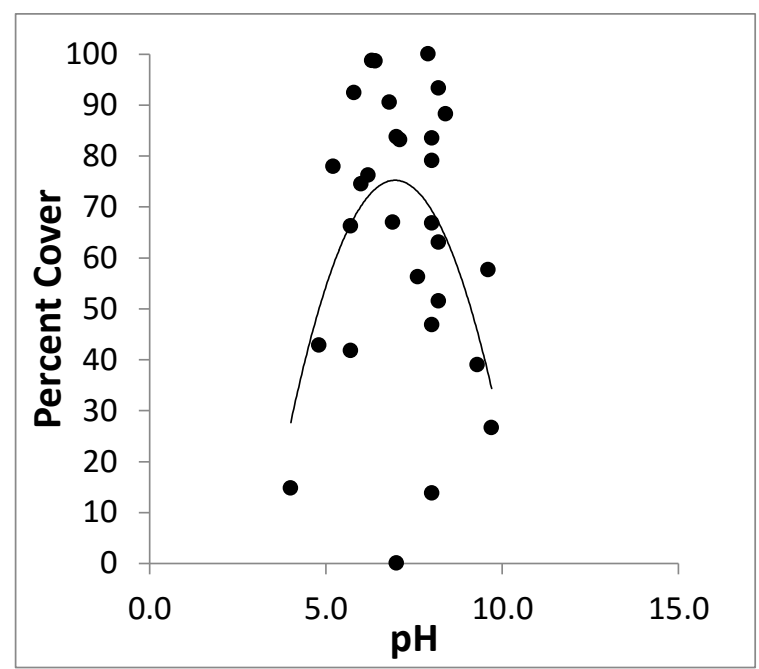

Figure 39: pH vs. percent cover

Organic matter was significantly different among cover class (Table 8), and there was a moderate positive correlation between $\mathrm{OM}$ and mean vegetation cover (correlation coefficient, $r$ $=0.49)$. Soils in $\mathrm{CC}$ I had the lowest levels of OM $(\leq 1.7 \%)$ that were less than desirable levels for growth (>2.0\%, Espinoza et al. 2006). Organic matter levels in the soils collected from CC II sites $(0.7-1.8 \%)$ as well as from the three median locations (1.7\%-2.0\%) also had less than optimal values. Soils from the best preforming sites (CC IV) had the greatest OM levels, ranging from $0.7 \%$ to $4.3 \%$. 
Table 8: Physical and chemical properties of soil by cover class reporting median and range (in parentheses). Letters indicate statistical significance, and $n$ is the number of samples within each cover class.

\begin{tabular}{|c|c|c|c|c|}
\hline Cover Class & I: $0-50 \%$ & II: $50-70 \%$ & III: $70-90 \%$ & IV: $90-100 \%$ \\
\hline$n$ & 8 & 7 & 8 & 6 \\
\hline OM (\%)* & $1.4(0.9-1.7)$ & $1.3(0.7-1.8)$ & $2.0(1.5-2.4)$ & $2.2(0.7-4.3)$ \\
\hline Sand (\%) & $\frac{a}{51.6(35.6-71.6)}$ & $\frac{a}{49.6(31.6-61.6)}$ & $\begin{array}{c}\mathrm{b} \\
47.6(43.6-71.6)\end{array}$ & $\begin{array}{c}b \\
58.6(43.2-93.2)\end{array}$ \\
\hline Silt (\%) & $\begin{array}{c}\mathrm{a} \\
34(8-42)\end{array}$ & $\begin{array}{c}a \\
28(24-46)\end{array}$ & $\frac{a}{30(16-34)}$ & $\begin{array}{c}a \\
26.4(0-38)\end{array}$ \\
\hline $\begin{array}{c}\text { Clay (\%)* } \\
\text { pH }\end{array}$ & $\begin{array}{c}a \\
16.4(4.4-24.4) \\
a b \\
7.5(4-9.7)\end{array}$ & $\begin{array}{c}\mathrm{a} \\
18.4(12.4-32.4) \\
\mathrm{ab} \\
8(5.7-9.6)\end{array}$ & $\begin{array}{c}\mathrm{a} \\
22.4(12.4-28.4) \\
\mathrm{a} \\
7.05(5.2-8.4)\end{array}$ & $\begin{array}{c}a \\
14.2(6.8-20) \\
b \\
6.6(5.2-8.2)\end{array}$ \\
\hline Soluble Salts & $0.84(0.36-1.54)$ & $0.52(0.08-1.15)$ & $0.35(0.21-0.81)$ & $0.26(0.09-0.45)$ \\
\hline $\begin{array}{c}(\mathrm{mmhos} / \mathrm{cm})^{\star} \\
\mathrm{N}(\mathrm{ppm})^{\star} \\
\mathrm{P}(\mathrm{pom})\end{array}$ & $\begin{array}{c}a \\
2(1-6) \\
a \\
3(2-13)\end{array}$ & $\begin{array}{c}a b \\
1(1-4) \\
a \\
5(4-23)\end{array}$ & $\begin{array}{c}\mathrm{bc} \\
3(1-6) \\
\mathrm{ab} \\
8(2-44)\end{array}$ & $\begin{array}{c}c \\
6(1-17) \\
b \\
75(2-18)\end{array}$ \\
\hline K (ppm) & $138(41-244)$ & $125(35-161)$ & $118(70-211)$ & $78(34-197)$ \\
\hline$M g(p p m)$ & $\begin{array}{c}a \\
212(64-658) \\
a b\end{array}$ & $\begin{array}{c}a \\
227(43-543) \\
a b\end{array}$ & $\begin{array}{c}a \\
318(178-663) \\
a\end{array}$ & $\begin{array}{c}a \\
154(34-435) \\
b\end{array}$ \\
\hline $\mathrm{Ca}(p p m)$ & $\begin{array}{c}2182.5(287-4240) \\
a b\end{array}$ & $\begin{array}{c}2785(212- \\
3530)\end{array}$ & $\begin{array}{c}2076(989-4236) \\
a b\end{array}$ & $\begin{array}{c}1528.5(204- \\
3445)\end{array}$ \\
\hline S (ppm) & $\begin{array}{c}50(8-348) \\
a\end{array}$ & $\begin{array}{c}a \\
12(7-68) \\
a b\end{array}$ & $\begin{array}{c}17.5(7-204) \\
a b\end{array}$ & $\begin{array}{c}b \\
8.5(5-64) \\
b\end{array}$ \\
\hline Zn (ppm) & $1.1(0.4-2.2)$ & $1.0(0.2-2.7)$ & $0.85(0.6-4.2)$ & $0.8(0.2-9.5)$ \\
\hline Mn (ppm)* & $\begin{array}{c}\mathrm{a} \\
10.75(3.2-19.8)\end{array}$ & $\begin{array}{c}a \\
6.7(3.4-27.7)\end{array}$ & $\begin{array}{c}a \\
9.8(3.6-22.3)\end{array}$ & $\frac{a}{3.8(2.5-8.5)}$ \\
\hline $\begin{array}{l}\mathrm{Cu}(\mathrm{ppm})^{*} \\
\mathrm{Fe}(\mathrm{ppm})\end{array}$ & $\begin{array}{c}\mathrm{a} \\
2.45(1.4-6.1) \\
\mathrm{a} \\
68.2(16.7-194.1)\end{array}$ & $\begin{array}{c}a \\
2.1(0.3-5) \\
a b \\
25(8.7-35.8)\end{array}$ & $\begin{array}{c}\mathrm{a} \\
1.65(0.6-5.4) \\
\mathrm{ab} \\
32.85(20.3-94.7)\end{array}$ & $\begin{array}{c}b \\
1.2(0.3-3.9) \\
b \\
32(11.3-64.2)\end{array}$ \\
\hline$B(p p m)^{\star}$ & $\frac{a}{0.4(0.3-1.2)}$ & $0.3(0.1-0.5)$ & $0.3(0.1-0.6)$ & $0.2(0.1-0.7)$ \\
\hline $\mathrm{Cl}$ (ppm) & $\begin{array}{c}a \\
15.96(6.38- \\
549.52)\end{array}$ & $\begin{array}{c}a b \\
120.19(9.22- \\
1946.37)\end{array}$ & $\begin{array}{c}a b \\
22.34(9.93- \\
274.41)\end{array}$ & $\begin{array}{c}b \\
30.49(12.05- \\
120.54)\end{array}$ \\
\hline $\mathrm{Na}(\mathrm{ppm})$ & $\frac{a}{19(7-1836)}$ & $\frac{a}{159(7-1259)}$ & $\frac{a}{23.5(12-240)}$ & $70.5(8.0-178.0)$ \\
\hline$E C(d S / m)$ & $\frac{a}{1.19}(0.35-2.24)$ & $\begin{array}{c}a \\
1.23(0.16-7.86)\end{array}$ & $0.49(0.24-2.62)$ & $0.5(0.11-1.22)$ \\
\hline & $\mathrm{a}$ & a & a & a \\
\hline
\end{tabular}




\subsection{Physical Characteristics}

\subsubsection{Compaction}

The comparison of percent cover to the maximum depth that the penetrometer reached is presented in Figure 40. As can be seen, the compaction rate of the soil at each subsite had minimal effect on the percent cover that was achieved by vegetation. Sites having a high compaction and low maximum depth still showed good vegetation. It must be noted that soils having high compaction typically have a difficulty of getting good seed penetration (Salon and Miller 2012). There is minimal change in percent cover from high compaction to loose soil.

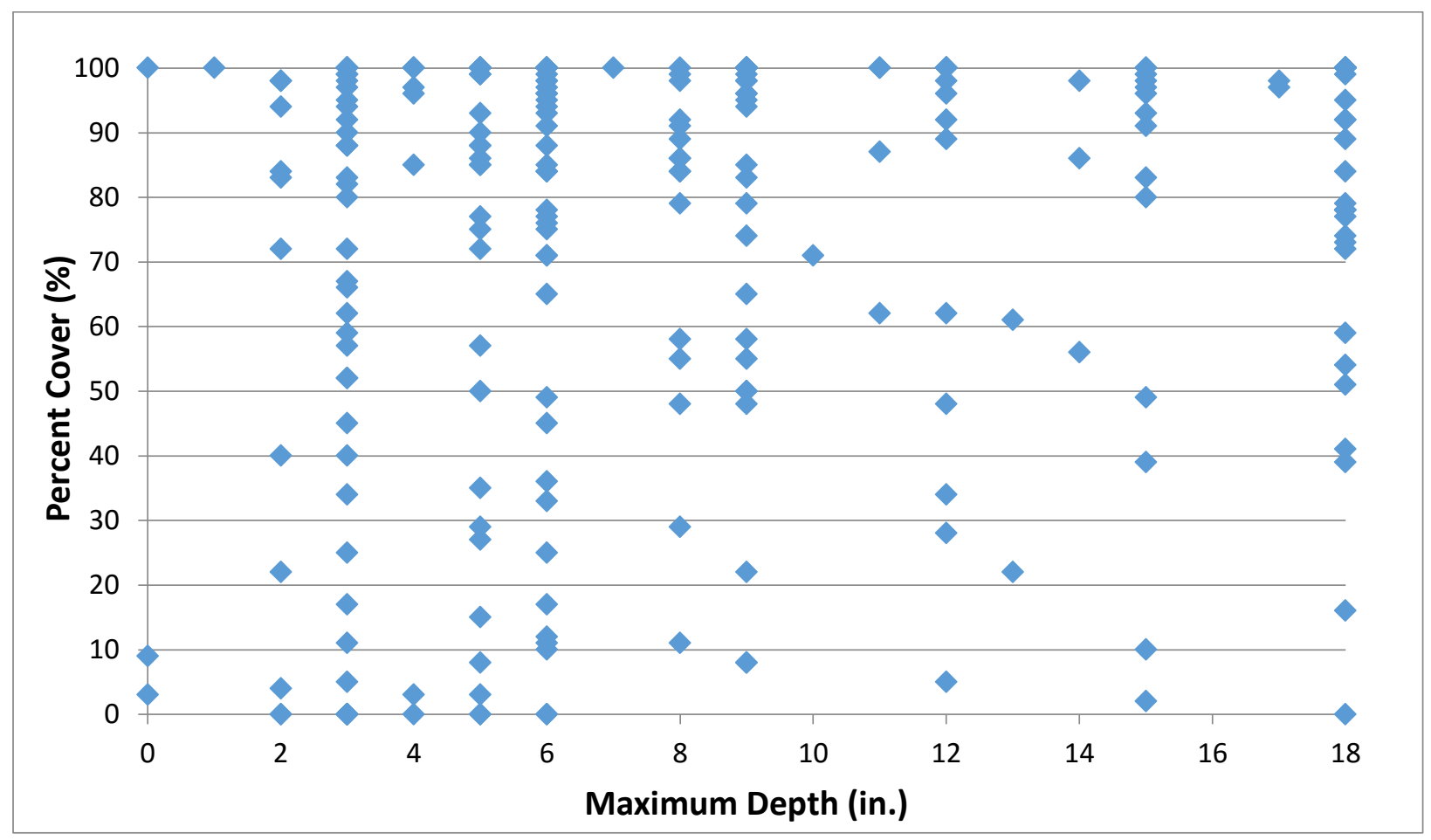

Figure 40: Percent cover vs. compaction depth

\subsubsection{Slope, Aspect, and Elevation}

Local slope measured at the cut and fill roadside sites reached a steep grade of $89 \%$.

While local slopes reached this steep gradient, the majority of the slopes were less than $50 \%$. Dominating local vegetation cover ( $>90 \%$ ) was present on slopes up to $80 \%$. Results from Wilcoxon tests indicated that there were limited statistical differences in cover class as defined 
by slope. Median sites were characterized by mild slopes (<25\%). Figure 41 summarizes the average slopes for each cover class.

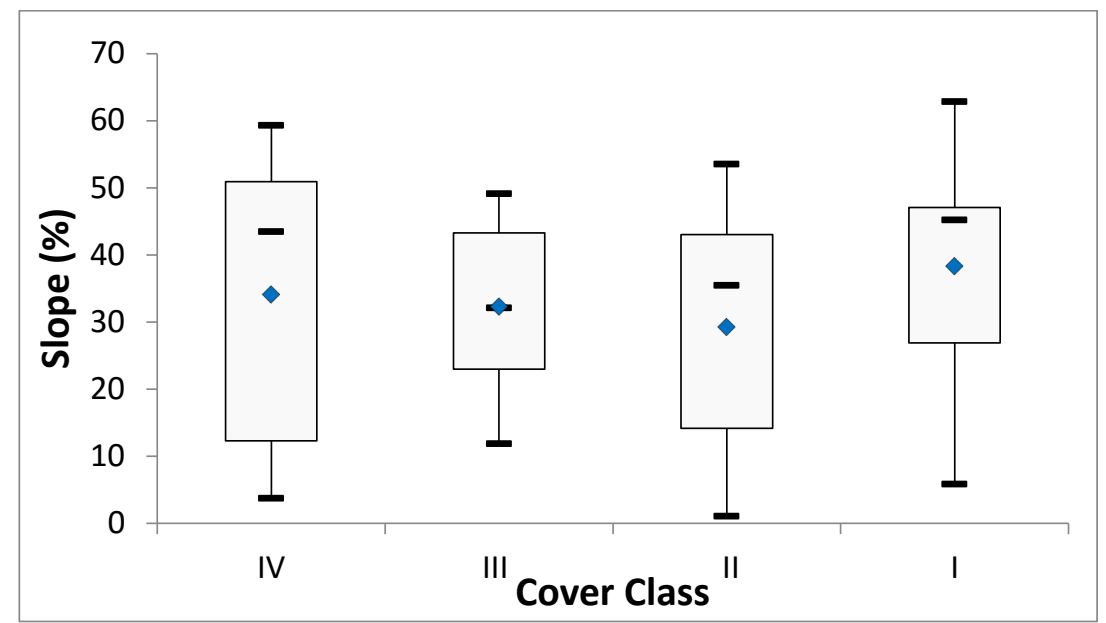

Figure 41: Percent cover vs. slope; $25 \%-75 \%$ (box); $\min$ and max (whisker); and mean (diamond)

Local measurements of aspect were distributed among the eight cardinal direction with the majority of slopes facing in the north, south, southwest, and west directions (N: $15.8 \%, N E$ : 7.9\%, E: 4\%, SE: 13.4\%, S: 10.3\%, SW: 23.7\%, W: 17.4\%, NW: 7.5\%). Data for median locations were removed as the median sites were characterized as gently sloping with no dominant direction. The greatest local percent cover values were present on the eastern facing slopes; however, only $4 \%$ of the local slopes faced the east direction. Percent cover poorly performed on the NE facing slopes (Figure 42). 


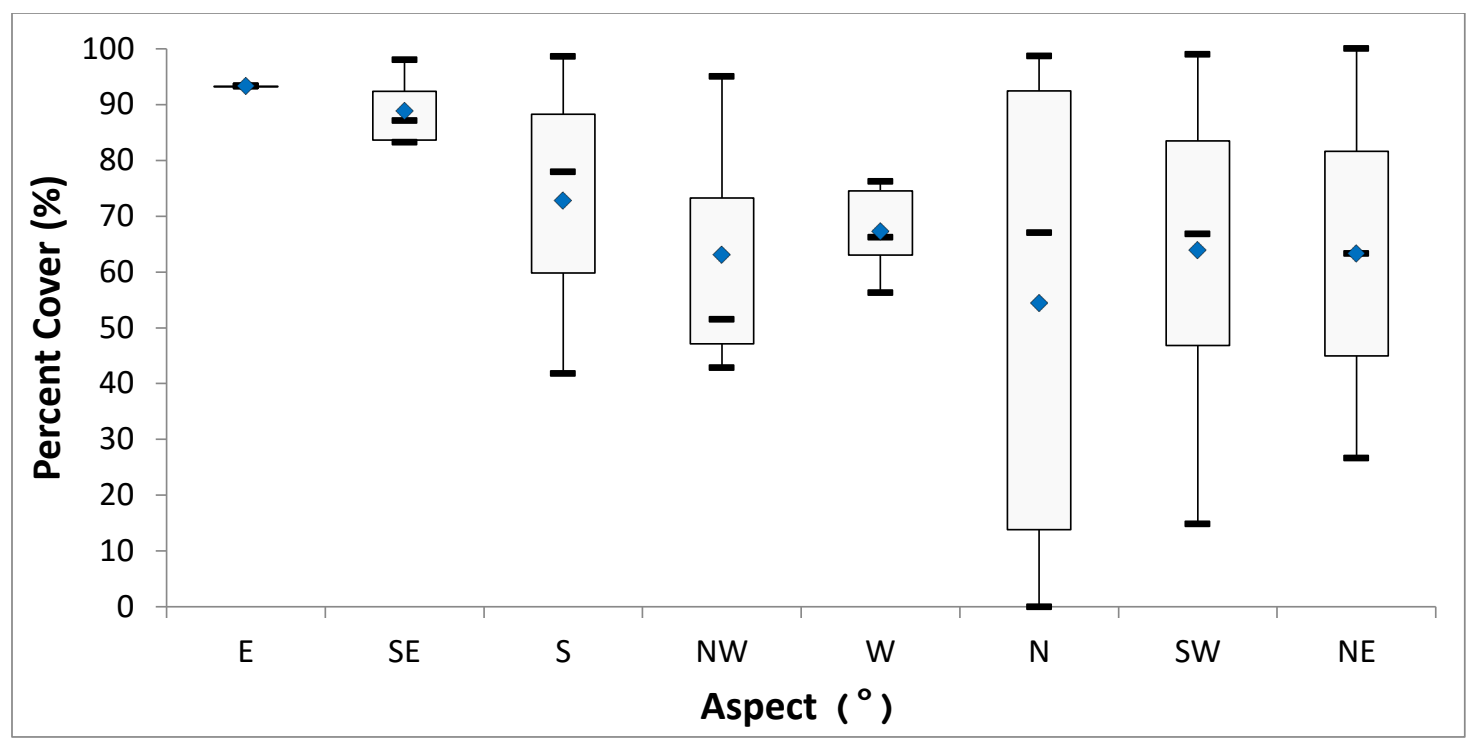

Figure 42: Percent cover vs. direction; 25\%-75\% (box); min and max (whisker); and mean (diamond)

Elevation ranges were 172-641 m, 146-636 m, 175-366 m, and 350-732 m for sites within CC I, II, III, and IV, respectively. Elevations of CC IV were statistically different than CC III when analyzed with Wilcoxon tests; however, there were no other statistically significant comparisons. There was no significant linear correlation between percent cover and elevation (Figure 43).

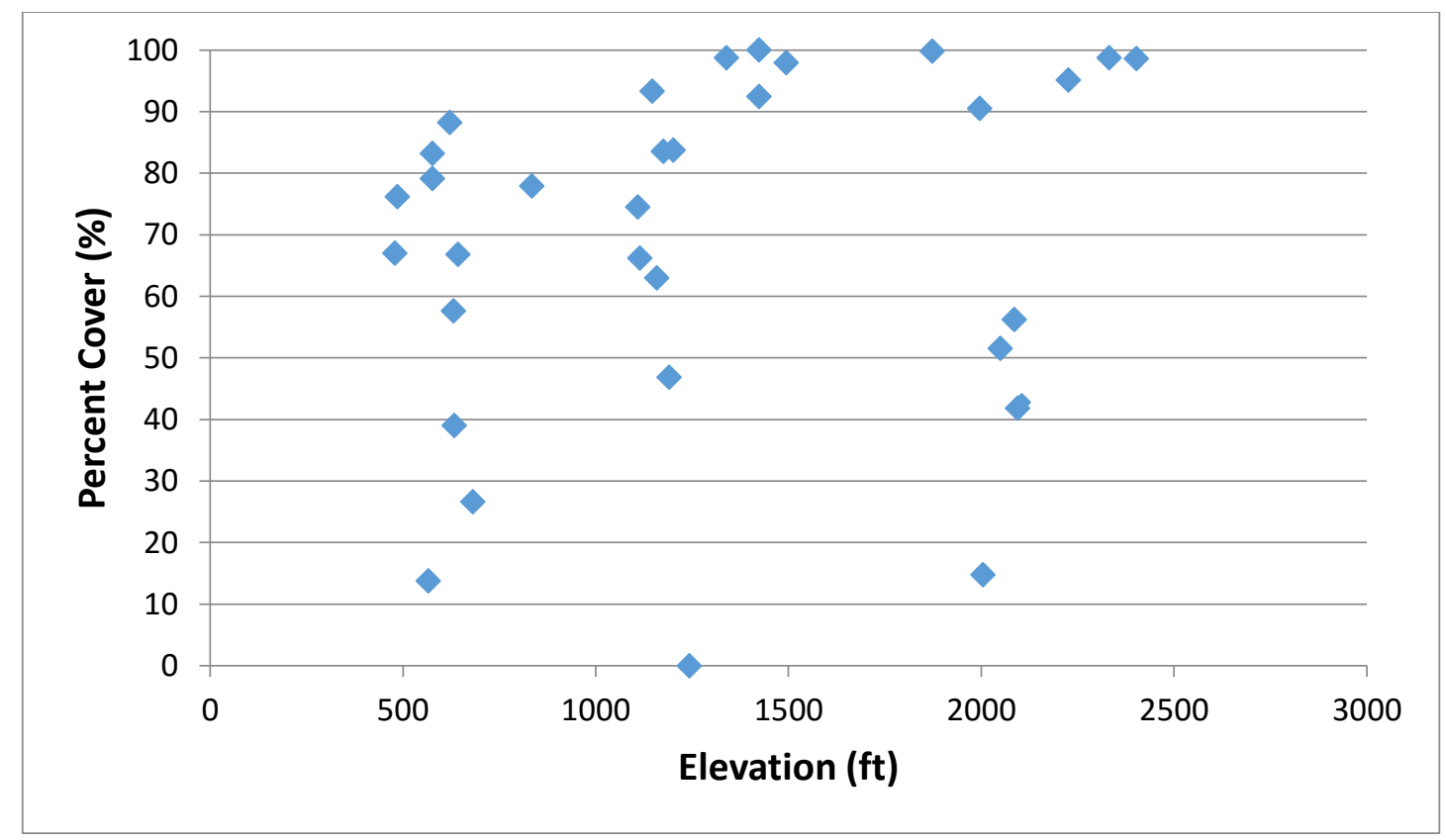

Figure 43: Percent cover vs. elevation 


\subsection{Factors Defining Percent Cover:}

From the results of the simple regressions, it was observed that soluble salts had the highest correlation to percent cover with a p-value of $7.79 \times 10^{-06}$. As a result, this was the first regressor entered into the model. The results can be seen in Table 9.

Table 9: Regression statistics of step 1: percent cover and soluble salts

\begin{tabular}{lcc}
\hline \multicolumn{3}{c}{ Regression Statistics } \\
\hline Equation 1: & \% Cover $=95.12$ & $-51.76(S S)$ \\
\hline Multiple R & 0.69 \\
\hline R Square & 0.48 \\
\hline Adjusted R Square & 0.46 \\
\hline Standard Error & 20.46 \\
\hline Significance F & $7.79 \mathrm{E}-06$ \\
\hline Observations & 33 \\
\hline \multicolumn{2}{l}{ Coefficients } & P-value \\
\hline Intercept & 95.12 & $3.0735 \mathrm{E}-16$ \\
\hline Soluble Salts (mmhos/cm) & -51.76 & $7.7914 \mathrm{E}-06$ \\
\hline
\end{tabular}

To continue the analysis, percent organic matter in the soil was used as the second independent variable. This was the second most significant at a p-value of $4.18 \times 10^{-3}$. The values of the results of step 2 can be seen in Table 10. The results show the step taken was to compare the independent variables, soluble salts, and percent organic matter, to the dependent variable, percent cover. Also, the results show that the Adjusted $R^{2}$ value increased from 0.46 to 0.55 . 
Table 10: Regression statistics of step 2: percent cover vs. soluble salts and percent organic matter

\begin{tabular}{|c|c|c|}
\hline \multicolumn{3}{|c|}{ Regression Statistics } \\
\hline Equation 2: & \multicolumn{2}{|c|}{$\%$ Cover $=71.80-45.26(S S)+11.42(\% O M)$} \\
\hline Multiple R & & 0.76 \\
\hline R Square & & 0.58 \\
\hline Adjusted R Square & & 0.55 \\
\hline Standard Error & & 18.78 \\
\hline Significance $\mathrm{F}$ & & $2.55 \mathrm{E}-06$ \\
\hline \multirow[t]{2}{*}{ Observations } & & 33 \\
\hline & Coefficients & P-value \\
\hline Intercept & 71.80 & $1.5192 \mathrm{E}-07$ \\
\hline Soluble Salts (mmhos $/ \mathrm{cm})$ & -45.26 & 3.0049E-05 \\
\hline$\% O M$ & 11.42 & 0.0142 \\
\hline
\end{tabular}

Forward selection was continued by evaluating each of the 12 remaining parameters in conjunction with \% OM and SS to determine the significance of the parameters on percent cover. It was found that Soluble Salts, \%OM, and Compaction were the only parameters that collectively had p-values that were below 0.05 seen in Table 11. Therefore, these parameters were the most significant in establishing percent cover.

Table 11: Regression statistics of step 3: percent cover vs. soluble salts, percent organic matter, and average depth of compaction test

\begin{tabular}{lcc}
\hline \multicolumn{3}{c}{ Regression Statistics } \\
\hline Equation 3: & \% Cover $=47.34-44.71(\mathrm{SS})+13.71(\% \mathrm{OM})+2.40$ (Compaction) \\
\hline Multiple R & 0.81 \\
\hline R Square & 0.65 \\
\hline Adjusted R Square & 0.61 \\
\hline Standard Error & 17.4 \\
\hline Significance F & $9.46-07$ \\
\hline Observations & 33 \\
\hline & Coefficients & $P$-value \\
\hline Intercept & 47.34 & 0.0021 \\
\hline Soluble Salts (mmhos/cm) & -44.71 & $1.3272-05$ \\
\hline$\% O M$ & 13.71 & 0.0026 \\
\hline Compaction (in.) & 2.40 & 0.0211 \\
\hline
\end{tabular}


The results show the step taken was to compare the independent variables, soluble salts, percent organic matter, and the average depth reached during the compaction test to the dependent variable, percent cover. Also, the results show that the Adjusted $\mathrm{R}^{2}$ value increased from 0.55 to 0.61 .

In order to confirm the results from forward selection, backward elimination was used. The results from the forward selection analysis were confirmed to be exactly the same as the backward regression. The independent variables, soluble salts, percent organic matter, and the average depth reached during the compaction test were significant in defining percent cover. The results can be seen in Table 12 .

Table 12: Regression statistics the final step of Backward Elimination

\begin{tabular}{lcc}
\hline \multicolumn{3}{c}{ Regression Statistics } \\
\hline Equation 4: $\quad$ \% Cover $=47.34-44.71(\mathrm{SS})+13.71(\% \mathrm{OM})$ & +2.40 (Compaction) \\
\hline Multiple R & 0.81 \\
\hline R Square & 0.65 \\
\hline Adjusted R Square & 0.61 \\
\hline Standard Error & 17.4 \\
\hline Significance F & $9.46-07$ \\
\hline Observations & 33 \\
\hline \multicolumn{2}{l}{ Coefficients } & $P$-value \\
\hline Intercept & 47.34 & 0.0021 \\
\hline Soluble Salts (mmhos/cm) & -44.71 & $1.3272-05$ \\
\hline \%OM & 13.71 & 0.0026 \\
\hline Compaction (in.) & 2.40 & 0.0211 \\
\hline
\end{tabular}




\section{Ch. 5 Discussion}

The use of vegetation as a management tool is cost effective, and vegetation persistence with limited maintenance is desired. At least $24 \%$ of the sites studied in this research need improvement in vegetation cover to provide desired erosion control benefits. Results showed that high organic matter, high fertility, and low soluble salts were present at locations with the largest amount of vegetation cover. Some improvements can be made through changes in seed bed preparation and maintenance, but the disturbed nature and harsh environment provides challenges.

Consistent with other studies (Block 2000; EPA 1997; Brown and Gorres 2011) organic matter was a significant factor is defining effective vegetation cover (Table 12). As $67 \%$ of soils were less than the optimal OM levels, the amendments to address this deficiency, as well as soil tests for application rates should be considered for future projects. As indicated in this study and by others, disturbed soil of highway construction projects is often characterized by low organic matter (Larney and Angers 2012; Booze-Daniels et al. 2000). However, a one-time application of organic matter can provide benefits. Brown and Gorres (2011) found increased vegetation establishment, growth, and persistence of turf grasses over two years with a onetime application of organic matter (e.g. biosolids and composted waste). Other work indicates that the addition of compost to disturbed sites may increase establishment and growth of fescue grasses initially, but additional applications may be needed for long-term impact (Dunifon et al. 2011). Current WVDOH standards have limited requirements for the use of topsoil, potentially limiting the amount of organic matter present during reclamation. In addition, the acceptable organic matter range for topsoil is $1.5-20 \%(\mathrm{WVDOH} 2010)$, and $1.5 \%$ is less than the optimal range (Espinoza et al. 2006). A preliminary soil test or increased use of topsoil (where appropriate) may improve initial OM levels. Specifications require a soil test for setting lime requirements (WVDOH 2010); however, this soil test does not typically report on OM. As OM is 
critical for sustained growth, soil tests should be completed and organic amendments or increased use of topsoil (where appropriate) should be considered for future reclamation sites.

While the addition of topsoil would likely provide benefits, it is not an applicable technique to all roadside construction sites and is costly (Booze-Daniels et al. 2000). Twentythree percent of the local slopes measured in this study were greater than $2: 1$, the recommended limit for the application of topsoil (Salon and Miller 2012; Booze-Daniels et al. 2000). Otherwise the topsoil will be susceptible to erosion. However, the majority of slopes measured at CC I sites were less than 2:1, so topsoil could have potentially been included at those sites. In addition, depth of application should be defined. In the eastern United States, depths of 25-35 cm may be required (Booze-Daniels 2000).

The abovementioned influences on cover class are supported by multiple regression results. The properties of organic matter, soluble salts, and compaction were considered significant in defining mean vegetation cover. The relationship accounted for $61.2 \%$ of the variability in mean vegetation cover (Table 13).

Table 13: Model predicting mean vegetation cover calculated by forward stepwise multiple regression analysis

\begin{tabular}{|c|c|c|}
\hline Variable & Coefficients & p-value \\
\hline Intercept & 47.34 & 0.0021 \\
\hline Soluble Salts (mmhos/cm) & -44.71 & $1.327 \mathrm{E}-05$ \\
\hline \%OM & 13.71 & 0.0026 \\
\hline Compaction - Avg. Depth (in.) & 2.40 & 0.0211 \\
\hline \multicolumn{2}{|c|}{ Adjusted $\mathrm{R}^{2}$} & 0.612 \\
\hline
\end{tabular}

Nitrogen was the only macronutrient that resulted in a positive correlation with vegetation cover, indicating the need for soil tests to set fertilizer levels. (Table 8). These results are consistent with a study of 13 cool-season grasses by Dudeck and Young (1970). They found that fertilized plots resulted in greater cover (68\%-70\% cover) than unfertilized plots (56\%-58\%). This difference was largely attributed to nitrogen. A one-time fertilizer application defined by soil 
tests is currently completed (WVDOH 2010). Follow-up soil tests could be beneficial in some cases and are often completed on poor performing sites. Continued fertility plans may be necessary for long-term cover. Alternatively, various soil amendments may be used to improve soil characteristics such as permeability, water retention and infiltration, aeration, drainage, and structure. Emerging hydraulic soil medium products could be a potential replacement to topsoil application, but at this time there are limited documentations of the various product performances, and the WVDOH standards do not typically allow for the use of organic additives.

Results support previous findings that salt is a limiting factor in roadside and median sites (Biesboer et al. 1998). Due to road management for snow removal, median sites were expected to be significantly affected by salt levels. Soils of two of the three median sites had elevated soluble salt values $(\mathrm{CHM}-1=0.77$ and $\mathrm{I} 68 \mathrm{M}=1.15)$. Roadside sites were also affected by elevated salt, consistent with work showing that salt impacts can reach a distance of $5 \mathrm{~m}$ from the road or more (Biesboer et al. 1998; Blomqvist and Johansson 1999; Bryson and Barker 2002; Cunningham et al. 2008). High levels of soluble salts defined CC I, but these were also locations of low fertility and organic matter. While salt-tolerant species can be used, species selected for low fertility will likely establish and persist better than species selected for high salt tolerance (Brown and Gorres 2011).

Species distributions were likely influenced by soluble salts. Crownvetch was often not present at sites with poor mean vegetation cover (CC I and II). These locations were also characterized by high soluble salts. Crownvetch, while tolerant to acidic soils, coarse soil textures, and low fertility, does not have a tolerance to salts (UDSA 2014).

Because $\mathrm{pH}$ did not vary linearly with vegetation cover, there was no correlation reported, and $\mathrm{pH}$ was not significant in the regression analysis. The sites with greatest vegetation cover, above the required $70 \%$, fell within the $\mathrm{pH}$ range of 5.2 and 8.4 . We expected low $\mathrm{pH}$ at these disturbed locations, but, surprisingly, found high $\mathrm{pH}(>7.5)$ at 15 sites. While low $\mathrm{pH}$ can be treated by liming, high $\mathrm{pH}$ treatment of non-calcareous alkaline soils can be 
treated with elemental sulfur, aluminum sulfate, and sometimes fertilizer with ammonium. However, calcareous soils with calcium carbonate parent material are not permanently treatable and are un-economical to lower pH (AgSource, personal communication; Salon and Miller 2012). The availability of macronutrients is also limited in soils with high $\mathrm{pH}$. This result shows the importance of the soil test in determining proper remediation rates.

This research suggests that slope, aspect, and elevation do not significantly affect the dominance of species on these slopes. The observed statistical differences were attributed to the high levels of soluble salts and low levels of organic matter at the sites. Our results do not support species selection based on slope direction. While eastern facing slopes resulted in the greatest local percent cover, the sample size of eastern facing slopes in this study was small. Local eastern aspect measurements primarily existed at MFE-1. This site had low levels of soluble salts $(0.41 \mathrm{mmhos} / \mathrm{cm})$, which likely contributed to the prevalence of crownvetch rather than the aspect. The poorest vegetation cover was observed at northeast facing slopes. These slopes were mostly present at $\mathrm{BH}$. This site had the greatest $\mathrm{pH}(9.7)$ and soluble salt (1.54 $\mathrm{mmhos} / \mathrm{cm}$ ) values of all sites. Therefore, aspect did not likely influence vegetation cover at $\mathrm{BH}$ as much as the poor soil quality. These results are consistent with research by Dudeck and Young (1970) who reported that aspect did not impact species performance. Their study considered 13 cool season grasses and crownvetch, on 4:1 north- and south-facing slopes in Nebraska. Exceptions included Kentucky bluegrass, western wheatgrass, and Penngift crownvetch, which had significantly greater percent cover on north-facing slopes.

While increased slope limits the application of top soil and mulching options, sites with adequate mean cover (>70\%) spanned the large range in slopes in the study. Species richness was low at slopes greater than 2:1 and closely reflected two grasses included in the WVDOH cut and fill slopes seed mixture (tall fescue and crownvetch). In this study, six locations had average slopes greater than 2:1 ( $\mathrm{CH}-5 \mathrm{~b}, \mathrm{~PB}, \mathrm{CH}-5 \mathrm{a}, \mathrm{CH}-3, \mathrm{MFE}-2$, and $\mathrm{CH}-2 \mathrm{a})$. Of these, two locations had average percent cover values less than $70 \%$ and were dominated by tall fescue 
(46\%-48\%). On the steep slopes with substantial cover (>90\%), more than $75 \%$ of the cover was attributed to crownvetch and tall fescue (Table 4). Species richness ranged from 3 to 4. The only exception was $\mathrm{CH}-5 \mathrm{a}$ which was primarily covered by sericea lespedeza (57\%) where the soil had a high sand content (89.9\%). An exception was made to the typical seed mixture at $\mathrm{CH}-5(\mathrm{CH}-5 \mathrm{a}$ and $\mathrm{Ch}-5 \mathrm{~b})$ to accommodate the uncharacteristically sandy soil.

The dominance of tall fescue and crownvetch was not limited to steep slopes. For the 18 plots with adequate average cover (>70\%), either tall fescue or crownvetch, or both, were substantially represented (Table 10). At these sites, species richness was equal to or less than 6 , close to the number typically included in seed mixtures (=4) (WVDOH 2010). Both crownvetch and tall fescue were identified as level 1 invasive by the West Virginia Department of Natural Resources. They are considered the most invasive, may change plant community composition, and establish readily, and spread rapidly (WVDNR 2009). These characteristics may be desirable for erosion control, but the inclusion of native species is also desired. The poor soil conditions and cost make the use of all native species difficult. Skousen and Venable (2008) showed that non-native species resulted in more cover initially after seeding, and native species provided more cover after a few years. If native species are used to develop an alternative seed mixture, increasing the numbers of species to $6-10$ in the mixture, may contribute to better performance (Kirmer et al. 2012). 


\section{Ch. 6 Conclusions:}

Establishing long-term vegetation cover at roadside and median locations is difficult due to harsh soil conditions and topography of West Virginia. In general, current remediation practices used by the WVDOH do not include as many detailed seeding stipulations as the surrounding states as well as the WVDEP. WVDOH currently uses only 4 mixtures which do not include native seeds. As the results show, this deficiency limits the effectiveness of vegetative cover as an erosion control method. Thirty percent of the sites examined in this study had excellent mean cover of greater than $90 \%$. Twenty-four percent of the sites were poorly covered $(<50 \%)$. Results showed that challenges faced during the time of establishment continue for long term persistence. High salt levels, low fertility, and improper compaction likely contributed the poorest mean cover values. In order to overcome some of these challenges, high priority should be taken to ensure that proper seed bed preparation as well as continued maintenance occurs. Topsoil could be utilized during seedbed preparation for slopes less than 2:1 and is currently used to a limited degree. Soluble salts levels influenced mean vegetation cover as well as species. Crownvetch was not observed at locations with high soluble salts, leading to poor mean vegetation cover. The most observed species, tall fescue (Festuca arundinacea) and crownvetch (Coronilla varia L.), are considered invasive but provided the majority of ground cover.

In order to improve current reclamation practices, topsoil could be utilized during seedbed preparation for slopes less than $2: 1$ to improve initial soil quality. Changes to seedbed preparation as well as continued maintenance can overcome some of these challenges but will increase cost. As previously mentioned, tall fescue and crownvetch are considered invasive but provided the majority of ground cover. To improve vegetation cover, using native seed mixtures can improve long term cover. It is more challenging to establish native plants by seed, but the use of native plants will be more successful and natural selection will continue (Salon and Miller 2012). Finally, proper maintenance of the reclamation sites will increase the overall vegetation 
coverage. When issues occur with vegetation, erosion of slopes or bare spots resultant of mowing, repair should be performed in a timely manner. Future work could be performed on testing the usage of native seed mixtures as well as new methods of seed bed preparation. This study was limited to the observations of current vegetation conditions. Because some of the sites evaluated were planted up to 10 years prior to this evaluation, it was not possible to track the weather patterns and conditions at the site for the sites' duration. Also, due to the time frame of the project, it was not possible to evaluate every location throughout the state. Finally, this project was performed over the span of two growing seasons, thus limiting the amount of data collected on bio mass. This project was desired to evaluate an overall observation of the long-term vegetation cover at roadsides and median locations in order to determine if current reclamation practices are sufficient. 


\section{Ch. 7 References:}

AgSource (2006). "Understanding a soil analysis." AgSource Laboratories. http://agsource.crinet.com/page2903/UnderstandingASoilAnalysis. Accessed 9 November 2014.

Biesboer, D.D., Neid, S., Darveau, B. (1998). "Salt tolerance in short-statured native grasses." Technical Report No. MN/RC-1998/16. Minnesota Department of Transportation.

Block, D. (2000). "Controlling erosion from highway projects." BioCycle 41: 59-62.

Blomqvist, G., Johansson, E. (1999). "Airborne spreading and deposition of deicing salt-a case study." Science Total Environ. 235:161-168.

Booze-Daniels, J.N., Daniels, W.L., Schmidt, R.E., Krouse, J.M., Wright, D.L. (2000). "Establishment of low maintenance vegetation in highway corridors." In: Barnhisel, R.I., Darmody, R.G., Daniels, W.L. (eds). "Reclamation of Drastically Disturbed Lands," American Society of Agronomy: Agronomy \#41, Madison, WI; 887-920.

Brown, R.N., and Gorres, J.H. (2011). "The use of soil amendments to improve survival of roadside grasses." HortScience, 46, 1404-1410.

Bryson, G.M., Barker, A.V. (2002). "Sodium accumulation in soils and plants along Massachusetts roadsides." Commun. Soil Science Plant Anal. 33:67-78.

Calloudon, B., Eshelman, K., Gianola, J., Habich, N., Hughes, L., Johnson, C., Pellant, M., Podborny, P., Rasmussen, A., Robles, B., Shaver, P., Spehar, J., Willoughby, J. (1996). Sampling vegetation attributes. Technical Reference 1734-4, Denver, Colo.: US Department of Agriculture.

Cunningham, M., Snyder, E., Yonkin, D., Ross, M., Elsen, T. (2008). “Accumulation of deicing salts in soils in an urban environment." Urban Ecosyst. 11:17-31.

Dudeck, A.E., Young, J.O. (1970). "Performances of crownvetch and selected cool season grasses on roadside backslopes as affected by slope exposure and nitrogen fertilization." Agron J 62:397-399.

Dunifon, S.N., Evanylo, G.K., Maguire, R.O., Goatley, J.M. Jr. (2011). "Soil nutrient and fescue (Festuca app.) responses to compost and hydroseed on a disturbed roadside." Compost Science Utilization, 19:147-151.

Elzinga, C. L., Salzer, D. W., \& Willoughby, J. W. (1998). Measuring and monitoring: Plant population. Technical Reference 1730-1, Denver, Colo.: US Bureau of Land Management. http://www.blm.gov/nstc/library/pdf/MeasAndMon.pdf

Espinoza, L., Slaton, N., Mozzaffari, M. (2006). "Understanding the numbers on your soil test report." University of Arkansas. Division of Agriculture and Natural Resources. FSA2118.

Gaffney, Frederick B., and Dickerson, John A., New York Department of Environmental Conservation (NYDEC). 2005. "Section 3-Vegetative Measures for Erosion and Sediment Control" New York Standards and Specifications for Erosion and Sediment Control: Syracuse, New York < http://www.dec.ny.gov/docs/water pdf/sec3.pdf > (September 12, 2013).

Kentucky Best Management Practices (KYBMPs) for Controlling Erosion, Sediment, and Pollutant Runoff from Construction Sites. "Section 4.4 Soil Stabilization". Planning and Technical Specifications Manual. <http://transportation.ky.gov/EnvironmentalAnalysis/Environmental\%20Resources/2-Soil\%20Stabilization.pdf> (July 29, 2014).

Kirmer, A., Baasch, A., Tischew, S. (2012). "Sowing of low and high diversity seed mixtures in ecological restoration of surface mined-land." Applied Vegetation Sci 15: 198-207.

Larney, F.J., Angers, D.A. (2012). "The role of organic amendments in soil reclamation: A review." Canadian J Soil Science. 92: 19-38.

Maryland Seeding Association (MSA). 2005a. "Section 6 - Fertilizer and Soil Amendments" Introduction to Web-Based Guideline Specifications for Seeding 2005. MSA: Severna 
Park, Maryland < http://www.marylandseeding.org/MSA_specs/H_MSA-GS-05.0_p.30-

37_Sec_6_Fertilizer_and_Soil_Amendments.pdf> (December 5, 2013) .

Maryland Seeding Association (MSA). 2005b. "Section 7 - Seed Mulches and Blankets" Introduction to Web-Based Guideline Specifications for Seeding 2005. MSA: Severna Park, Maryland < http://www.marylandseeding.org/MSA specs/l MSA-GS-05.0 p.38$43 \mathrm{Sec} 7$ Seed Mulches and Blankets.pdf> (December 5, 2013).

Maryland Seeding Association (MSA). 2005c. "Section 8 - Temporary Seeding" Introduction to Web-Based Guideline Specifications for Seeding 2005. MSA: Severna Park, Maryland < http://www.marylandseeding.org/MSA_specs/J_MSA-GS-05.0_p.44-

49_Sec_8_Temporary_Seeding.pdf> (December 5, 2013) .

Maryland Seeding Association (MSA). 2005d. "Section 9 - Erosion Control Seeding" Introduction to Web-Based Guideline Specifications for Seeding 2005. MSA: Severna Park, Maryland <http://www.marylandseeding.org/MSA_specs/K_MSA-GS-05.0_p.50 58_Sec_9_Erosion_Control_Seeding.pdf> (December 5, 2013) .

Maryland Seeding Association (MSA). 2005e. "Section 13 - Highway Seeding" Introduction to Web-Based Guideline Specifications for Seeding 2005. MSA: Severna Park, Maryland < http://www.marylandseeding.org/MSA specs/O MSA-GS-05.0 p.87111_Sec_13_Highway_Seeding.pdf $>$ (December 5, 2013) .

Montgomery, D. C., Peck, E. A., and Vining, G. G. (2006). Introduction to Linear Regression Analysis, $4^{\text {th }}$ Ed., Chapter 9.2, Pages 277-283 Wiley, Hoboken, New Jersey

New York State Department of Transportation (NYSDOT). 2002. "Section 610-Turf and Wildflower Establishment" New York Standard Specifications; Construction and Materials: Syracuse, New York < https://www.dot.ny.gov/main/businesscenter/engineering/specifications/specs-repository/vol1active1_15_04.pdf> (September 30, 2013).

New York Department of Environmental Conservation (NYDEC). 2005. "Section 3 - Vegetative Measures for Erosion and Sediment Control" http://www.dec.ny.gov/docs/water pdf/sec3part1.pdf (October 19, 2015)

North Carolina Department of Transportation (NCDOTa). "General Seed Specification" NCDOT GENERAL SEED SPECIFICATION FOR SEED QUALITY: Raleigh, North Carolina < http://www.ncdot.gov/doh/operations/dp chief eng/roadside/soil water/pdf/seedquality.p $\underline{\mathrm{df}}>$ (September 30, 2013).

North Carolina Department of Transportation (NCDOTb). "Vegetation Management Section" North Carolina Department of Transportation Roadside Environmental Unit: Raleigh, North Carolina $<$ http://www.ncdot.gov/doh/operations/dp chief eng/roadside/vegetation/materials/orgfe rt.html> (March 28, 2014).

North Carolina Department of Transportation (NCDOT). 2012. "Section 1660" Standard Specifications for Roads and Structures: Raleigh, North Carolina $<$ https://connect.ncdot.gov/resources/Specifications/Specification\%20Resources/2012\% 20Standard\%20Specifications.pdf > (December 5, 2013).

North Carolina Department of Transportation (NCDOT). 2003. "Section 5.6.2 Permanent Seeding and Mulching" Best Management Practices for Construction and Maintenance Activities: Raleigh, North Carolina < http://www.ncdot.gov/doh/forms/files/BMPMANUAL.pdf > (March 25, 2014).

North Central Regional (NCR) 1988. Publication No. 221 (Revised). Recommended Chemical Procedures for the North Central Region Bulletin No. 499 (Revised) October 1988. 
Ohio Department of Transportation (ODOT). 2013. "Item 659 Seeding and Mulching". Construction and Material Specifications. ODOT: Columbus, OH. < http://www.dot.state.oh.us/Divisions/ConstructionMgt/OnlineDocs/Specifications/2013C MS/2013_CMS_11142012_FINAL.PDF> (February 21, 2014).

Pennsylvania Department of Transportation (PennDOT). 1998. "Section 804" Seeding and Soil Supplements Publication 408 Pennsylvania DOT: Harrisburg, Pennsylvania $<$ http://www.dot.state.pa.us/Penndot/reginfo.nsf/0/44d60835e34b4741852567a10073c9 7c?OpenDocument> (July 18, 2013).

Pennsylvania Department of Environmental Protection (PennDEP). 2009. "Chapter 11 - " Erosion and Sediment Control BMP Manual. Document Number: 363-2134-008: Harrisburg, Pennsylvania <http://www.jonestownship.com/Erosion\%20\&\%20Sediment\%20BMP.pdf> (March 28, 2014).

Salon, P.R., Miller, C.F. (2012). "A Guide to: Conservation Plantings on Critical Areas for the Northeast." USDA, NRCS, Big Flats Plant Materials Center, Corning, NY. http://plantmaterials.nrcs.usda.gov/nypmc/. (June 10, 2014).

Skousen, J.G., Venable, C.L. (2008). "Establishing native plants on newly-constructed and older-reclaimed sites along West Virginia Highways." Land Degrad Dev 19: 388-396.

South Carolina Department of Transportation (SCDOT). 2011a. "Seeding" Supplemental Technical Specification for Seeding. SCDOT Designation: SC-M-810-2(04/11): Columbia, South Carolina <http://www.scdot.org/doing/technicalpdfs/suptechspecs/scm-810-2.pdf> (July 17, 2013).

South Carolina Department of Transportation (SCDOT). 2011b. "Supplemental Technical Specification for Hydraulic Erosion Control Products." SCDOT Designation: SC-M-81511(04-11): Columbia, South Carolina $<$ http://www.scdot.org/doing/technicalPDFs/supTechSpecs/SC-M-815-11.pdf $>$ (January $27,2015)$

Tennessee Department of Transportation (TDOT). "Item 4 - 1. Seed Mixes and Planting Seasons". Manual for Management of Storm Water Discharges Associated with Construction Activities. TDOT: Nashville, TN. < http://www.tdot.state.tn.us/sswmp/pdfs/ConstManual.pdf> (July 18, 2013).

USDA, NRCS. 2014. The PLANTS Database (http://plants.usda.gov, 5 June 2014). National Plant Data Team, Greensboro, NC 27401-4901 USA.

Virginia Department of Transportation (VDOT). 2007. "Section 603-Seeding". Road and Bridge Specifications. VDOT: Richmond, Virginia. < http://www.virginiadot.org/business/resources/const/2007SpecBook.pdf> (September 30, 2013).

Virginia Department of Transportation (VDOT) . 2013. "Roadside Development Sheet" Project Number 0704-082-707, M501. VDOT: Richmond, Virginia. < https://www.google.com/url?sa=t\&rct=i\&q=\&esrc=s\&source=web\&cd=4\&ved=0CDgQFiA D\&url=https\%3A\%2F\%2Fwww.bidx.com\%2Fva\%2Fattachment\%3F id\%3D52610e4a37 e274ee3b0000dc\&ei=4YotU57HB-

SwyQGWvIDgDQ\&usg=AFQjCNFK4J5MFRrAorZoso3H3Xx4f6CHg\&bvm=bv.62922401,d.aWc\&cad=rja> (November 4, 2013).

Virginia Department of Transportation (VDOTSPEC). 2013. "Procedures and Rational" Specifications for Standard and Non-standard Seed. VDOT: Richmond, Virginia $<$ http://www.virginiacrop.org/VDOT\%20\%20methods\%20and\%20procedures\%20Sept\% 202013.pdf> (March 22, 2014).

West Virginia Department of Environmental Protection (WVDEP). 2010. "Section 6.0 Revegetation" Standardization of Plans, Specs, 8.27.2010.pdf: Charleston, West Virginia 
$<$ http://www.dep.wv.gov/aml/standards/Documents/Standardization\%20of\%20plans\%20 and\%20specs.pdf $>$ (October 2013).

West Virginia Department of Environmental Protection (WVDEP). 2006a. "Section 3.10Temporary Seeding" Erosion and Sediment Control Best Management Practice Manual: Charleston, West Virginia $<$ http://www.bluefieldstormwater.org/uploads/3/0/1/1/3011957/erosion sediment contr ol manual.pdf $>$ (October 2013).

West Virginia Department of Environmental Protection (WVDEP). 2006b. "Section 3.11Permanent Seeding" Erosion and Sediment Control Best Management Practice Manual: Charleston, West Virginia $<$ http://www.bluefieldstormwater.org/uploads/3/0/1/1/3011957/erosion sediment contr ol manual.pdf $>$ (October 2013).

West Virginia Division of Highways (WVDOH). 2010. "Section 652-Seeding and Mulching" Standard Specifications Roads and Bridges: Charleston, West Virginia <http://www.transportation.wv.gov/highways/contractadmin/specifications/Documents/20 10\%20Standard\%20Specifications\%20Roads\%20and\%20Bridges/Complete\%20Publica tions/2010StandardRoadsnBridges.pdf> (October 2013).

West Virginia Division of Natural Resources (WVDNR) Natural Heritage Program (2009). Invasive Plant Species of West Virginia.

http://www.wvdnr.gov/Wildlife/Handout\%20Invasive\%20Plants\%20of\%20WV\%202009.p df (February 11, 2015). 


\section{Ch. 8 Appendices:}

\subsection{Appendix A: Observed Vegetation}

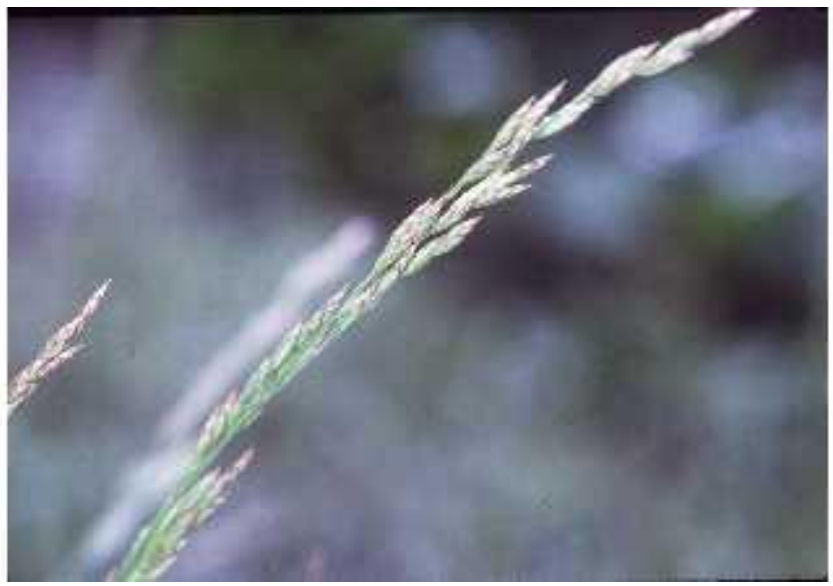

Figure 44: Tall Fescue (Kentucky 31 Fescue) - Provided by Robert H. Mohlenbrock, hosted by the USDA-NRCS PLANTS Database / USDA SCS. 1989. Midwest wetland flora: Field office illustrated guide to plant species. Midwest National Technical Center, Lincoln.

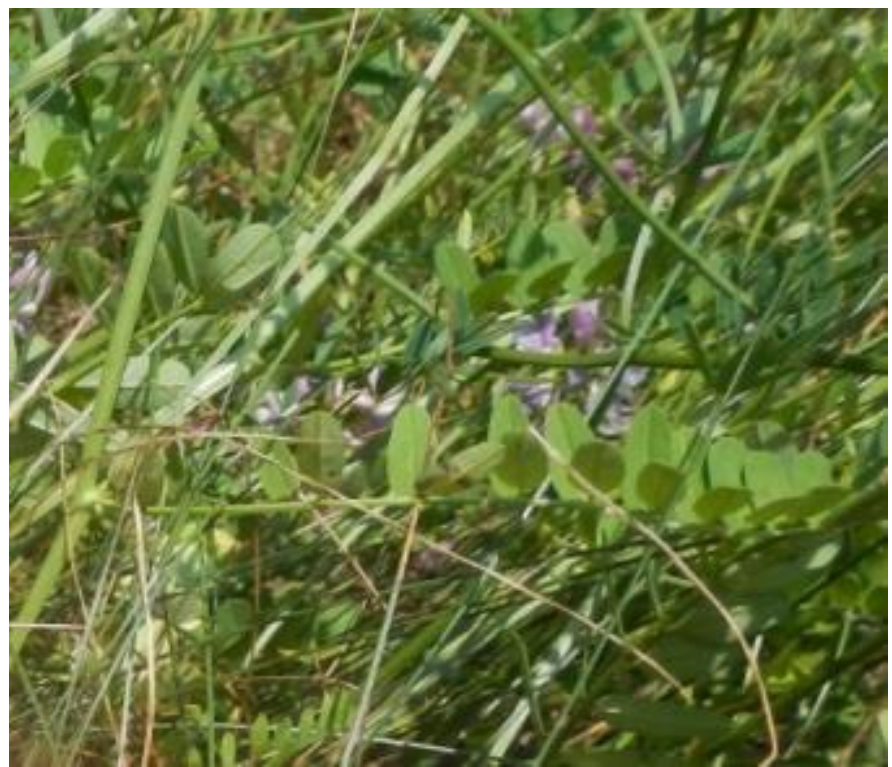

Figure 45: Crownvetch 


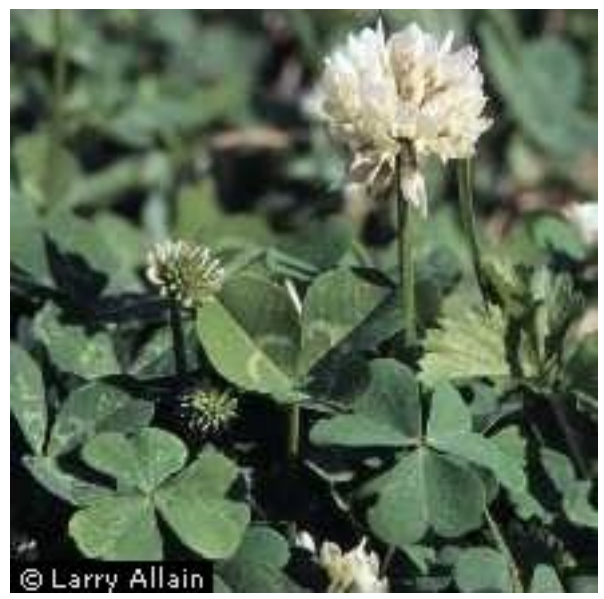

Figure 46: White Clover - Provided by Larry Allain, hosted by the USDA-NRCS PLANTS Database

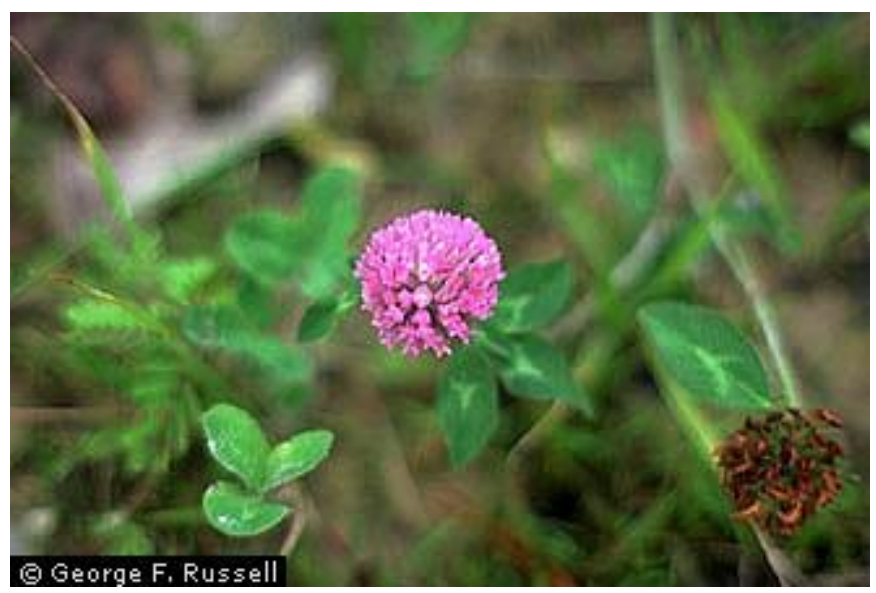

Figure 47: Red Clover - Provided by Rusty Russell, hosted by the USDA-NRCS PLANTS Database

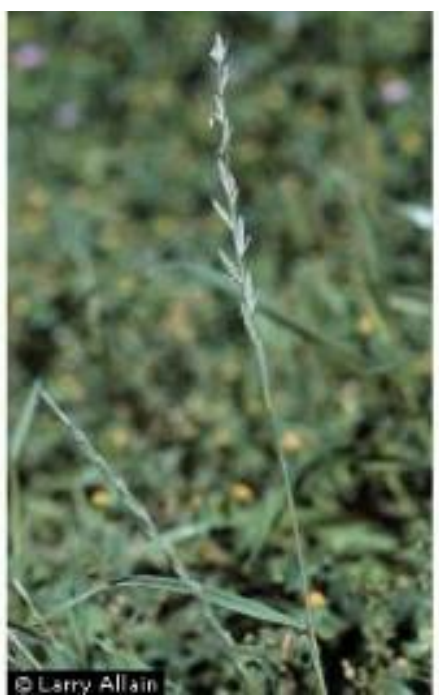

Figure 48: Annual Ryegrass - Provided by Larry Allain, hosted by the USDA-NRCS PLANTS Database 


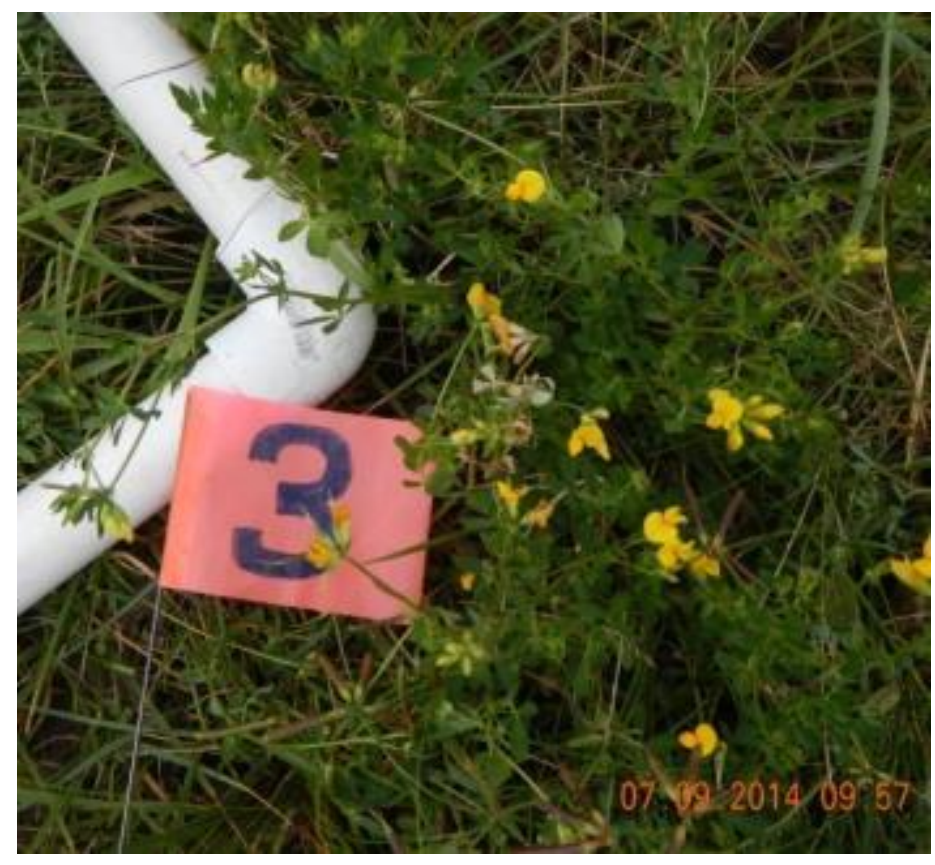

Figure 49: Birdsfoot Trefoil

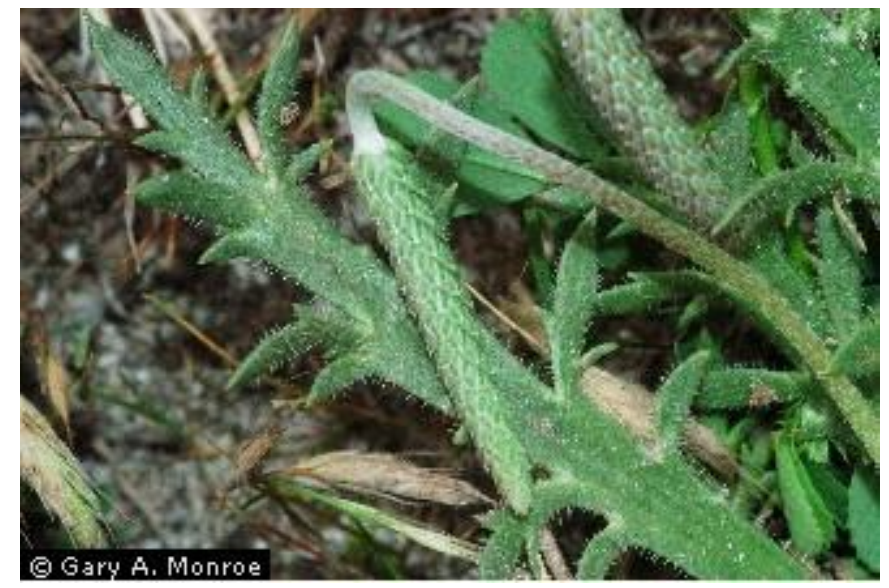

Figure 50: Buckhorn Plantain - Provided by Gary A. Monroe, hosted by the USDA-NRCS PLANTS Database 


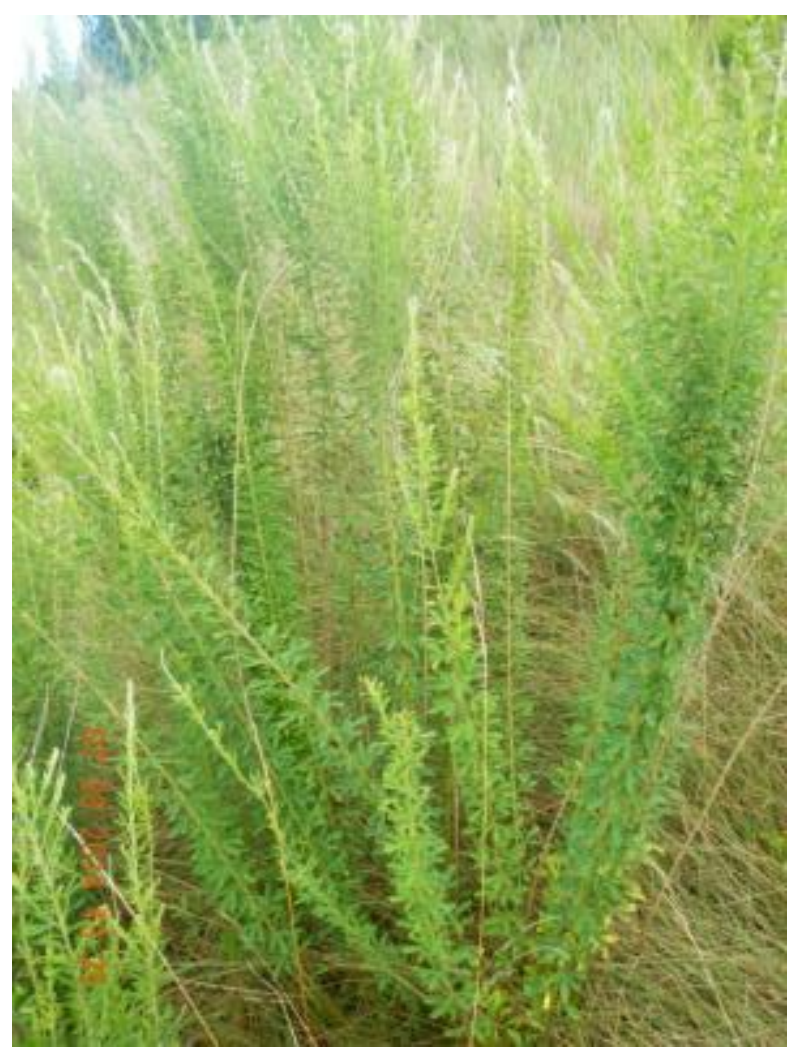

Figure 51: Serecia Lespedeza

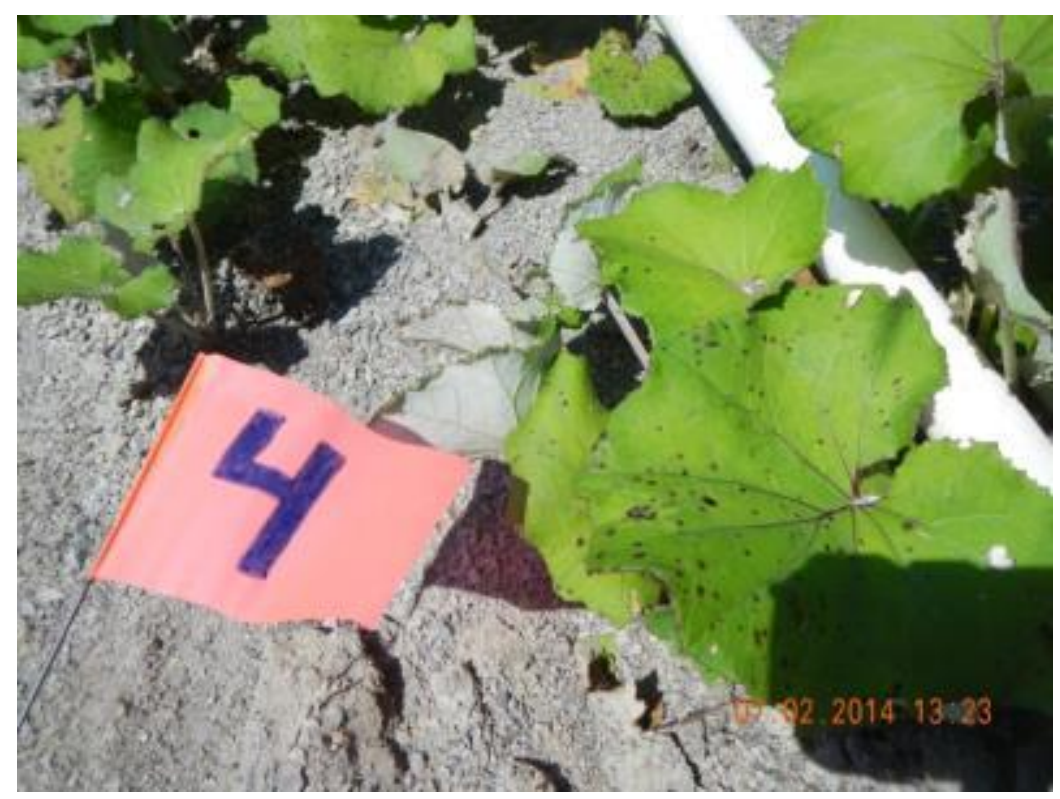

Figure 52: Coltsfoot 
8.2 Appendix B: Field Work and Equipment Photos

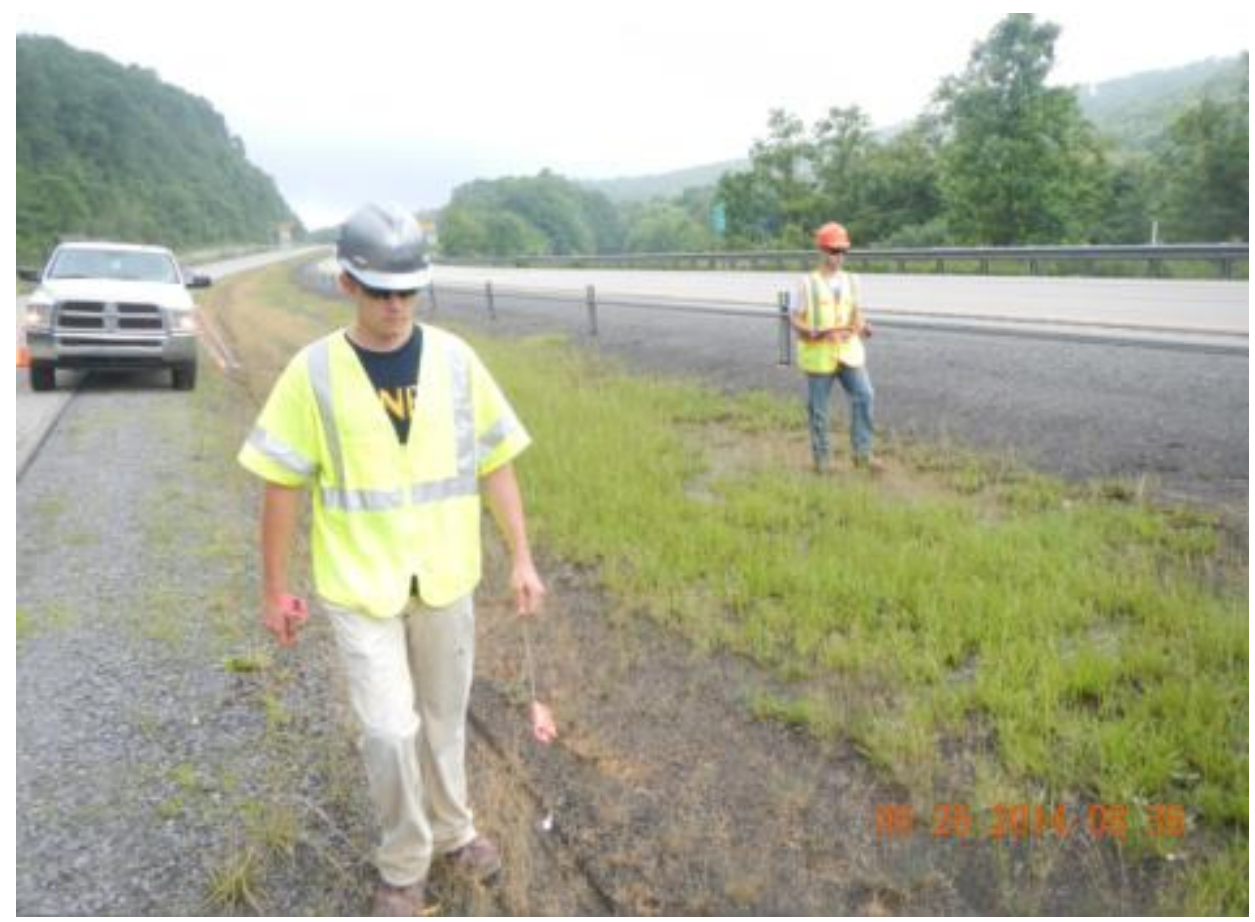

Figure 53: Marker flag placement for site location at I-68 median

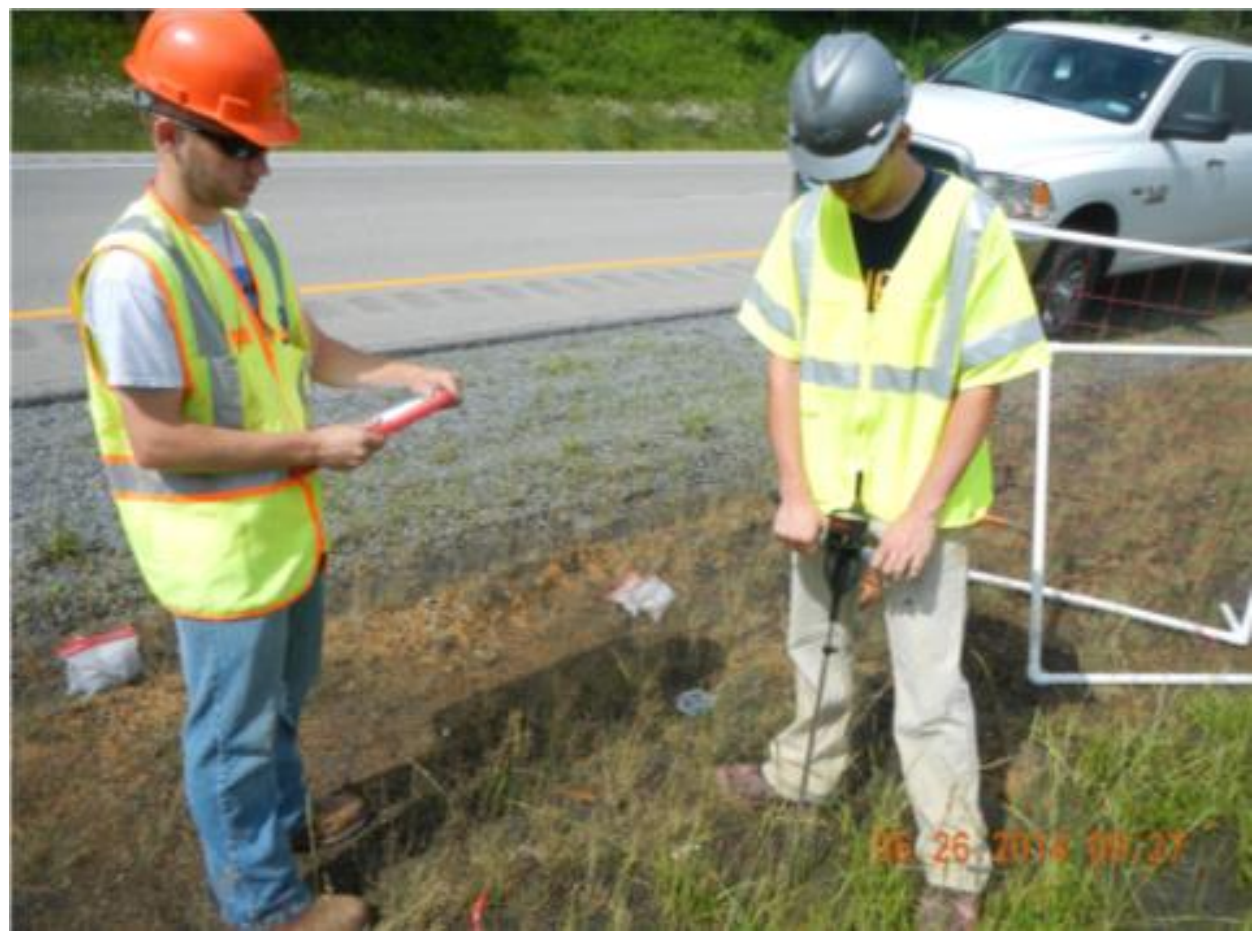

Figure 54: Soil compaction testing with penetrometer at I-68 median 


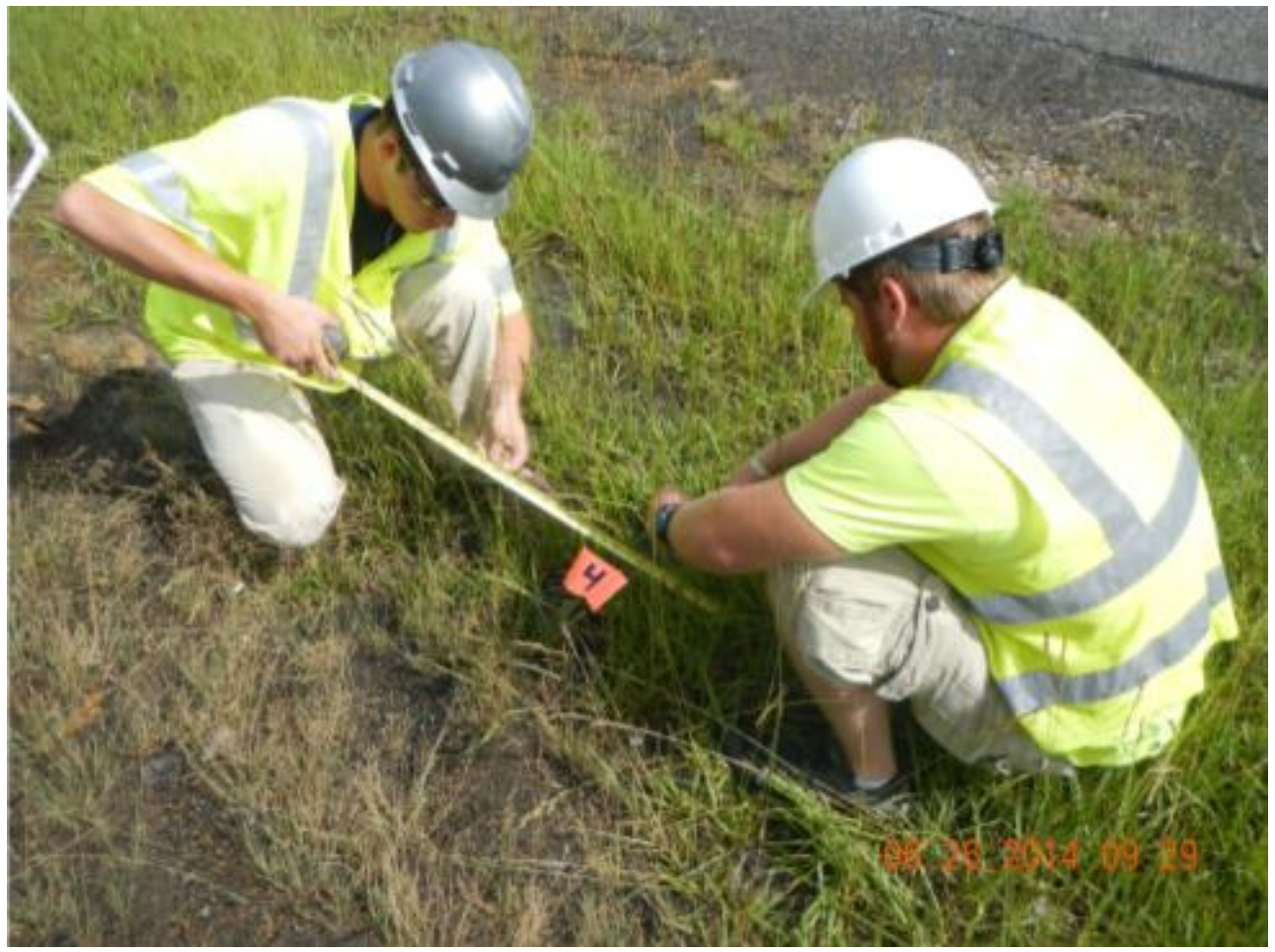

Figure 55: Vegetation stem measurement at I-68 median

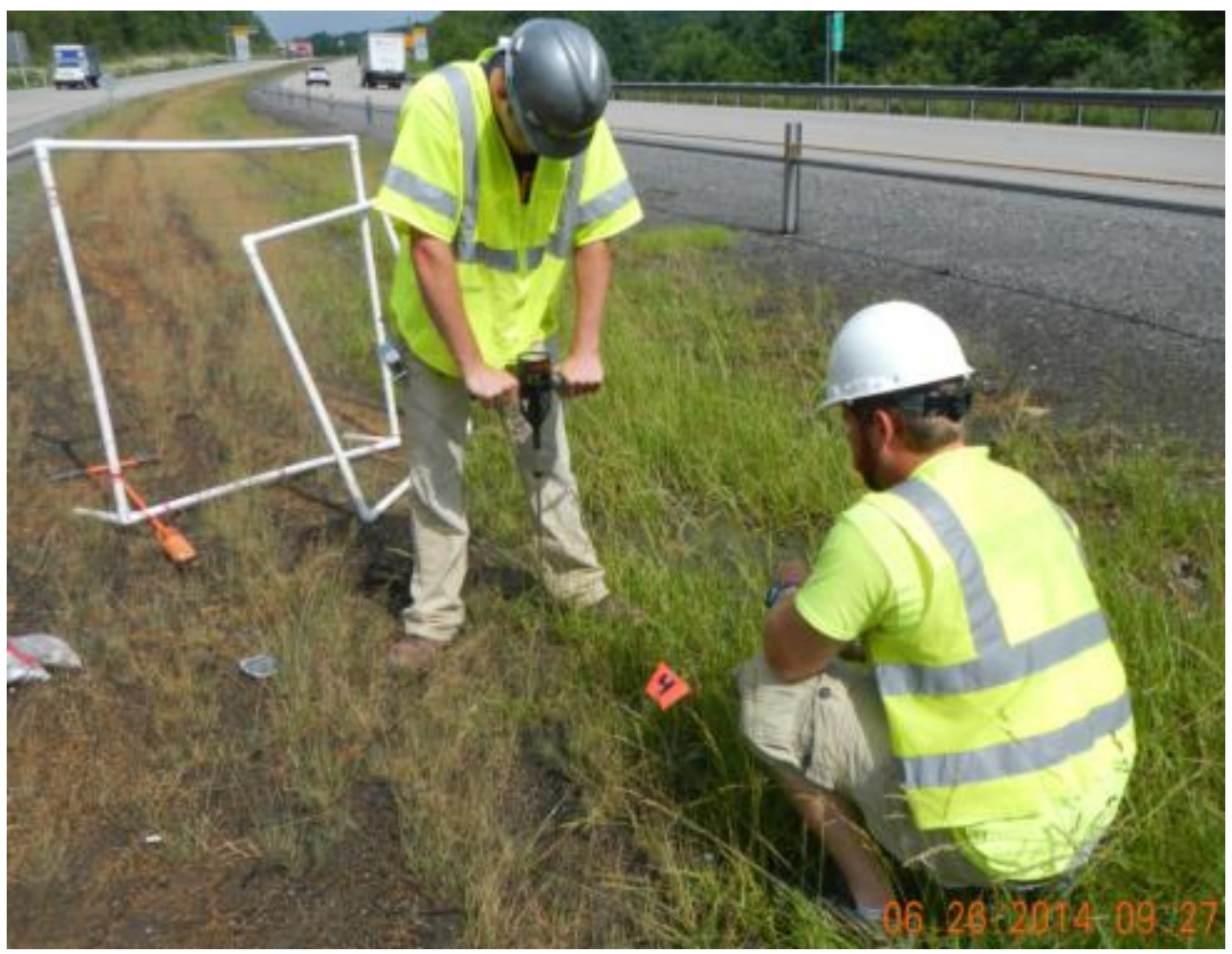

Figure 56: Compaction testing with penetrometer at I-68 median 


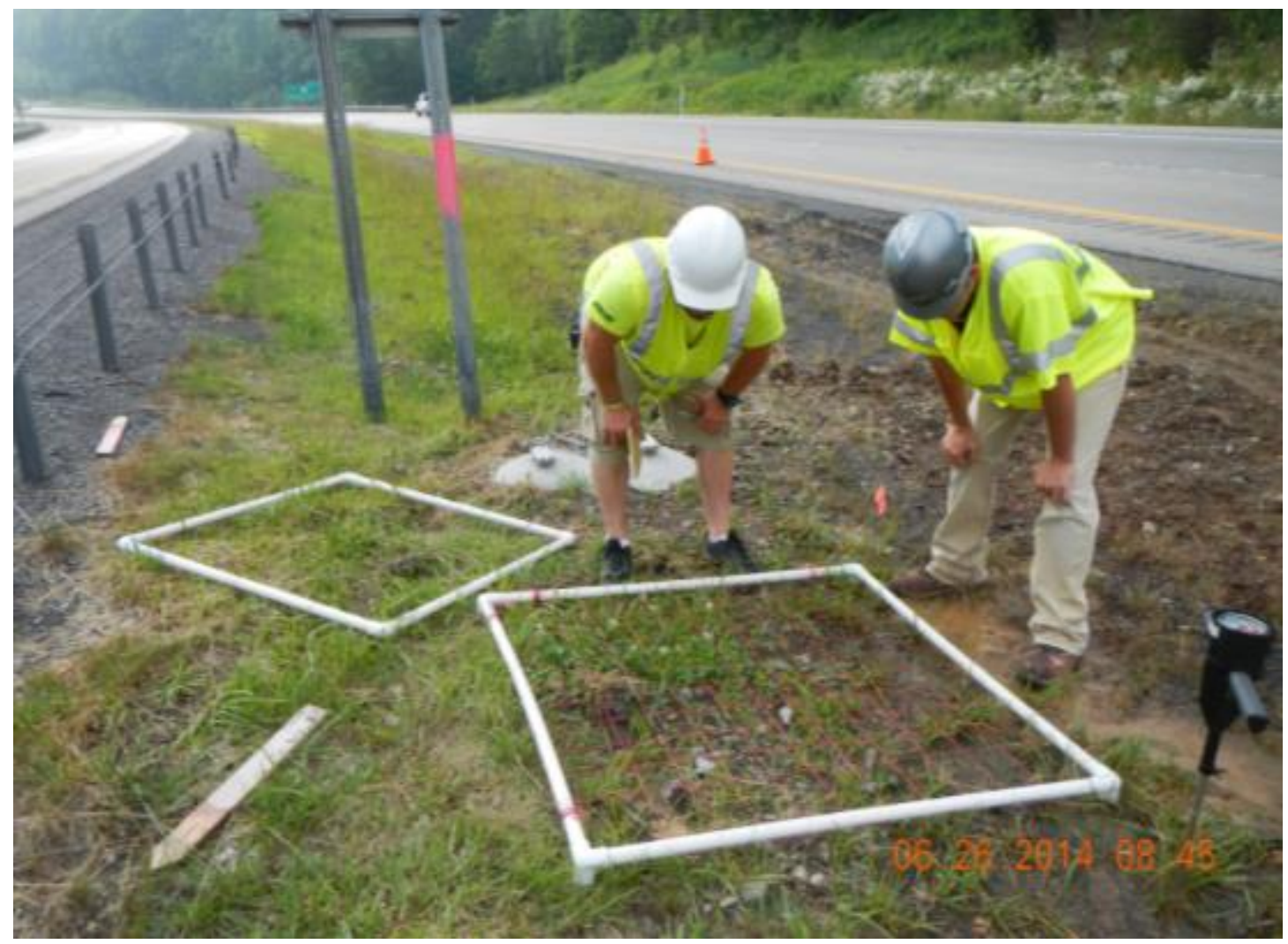

Figure 57: PPF evaluation at I-68 median

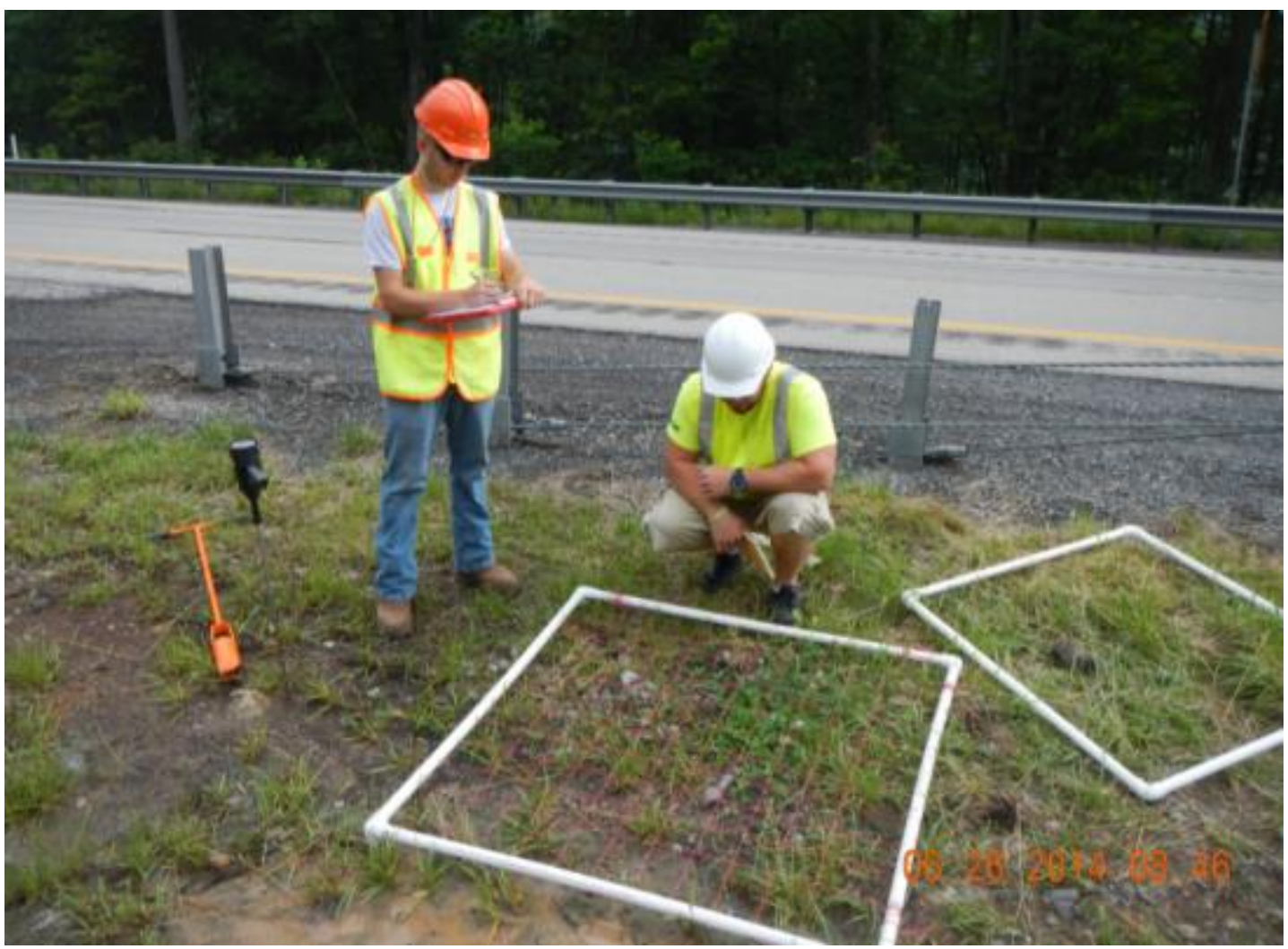

Figure 58: PPF evaluation at I-68 median 


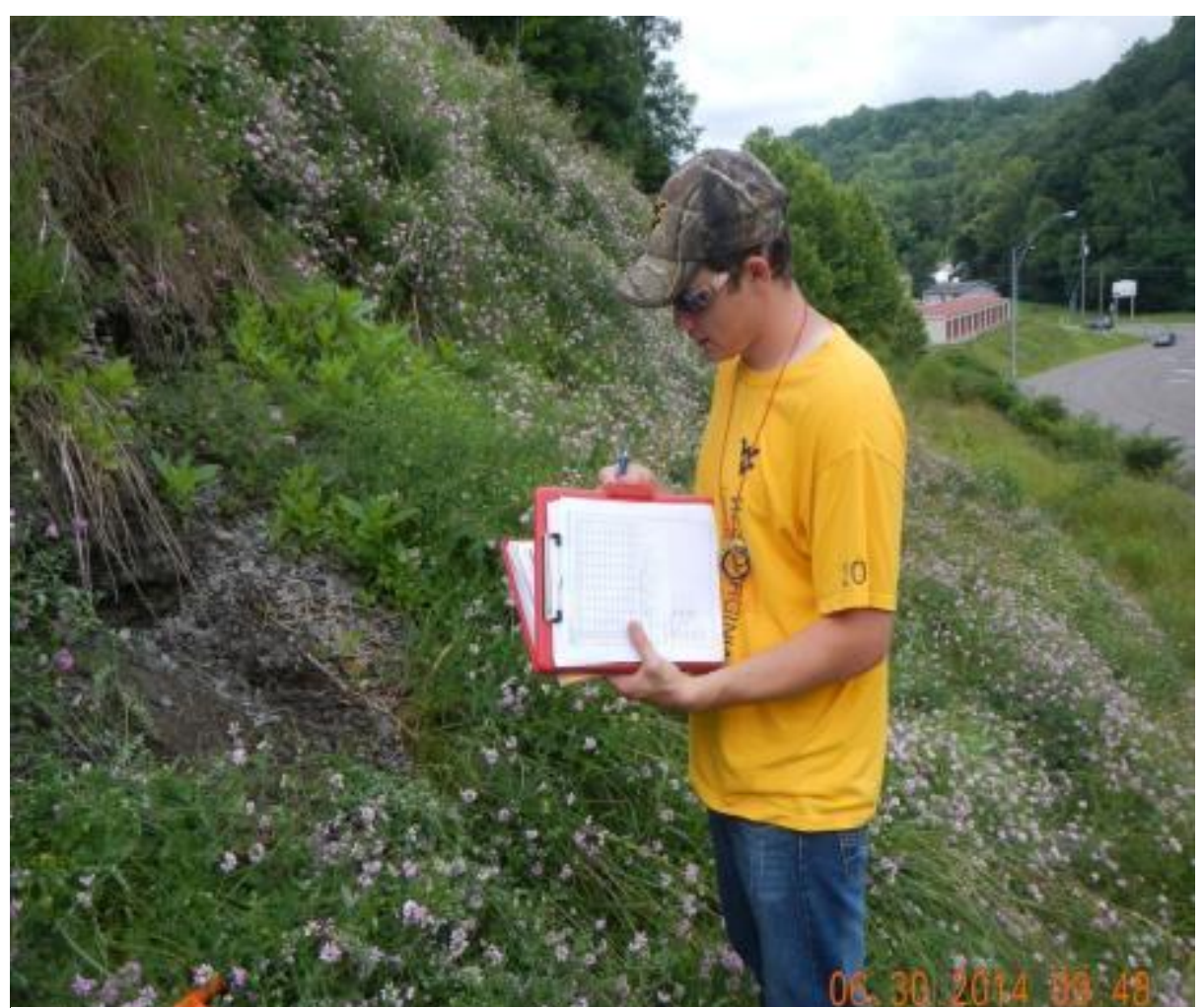

Figure 59: Data recording at Philippi Bypass

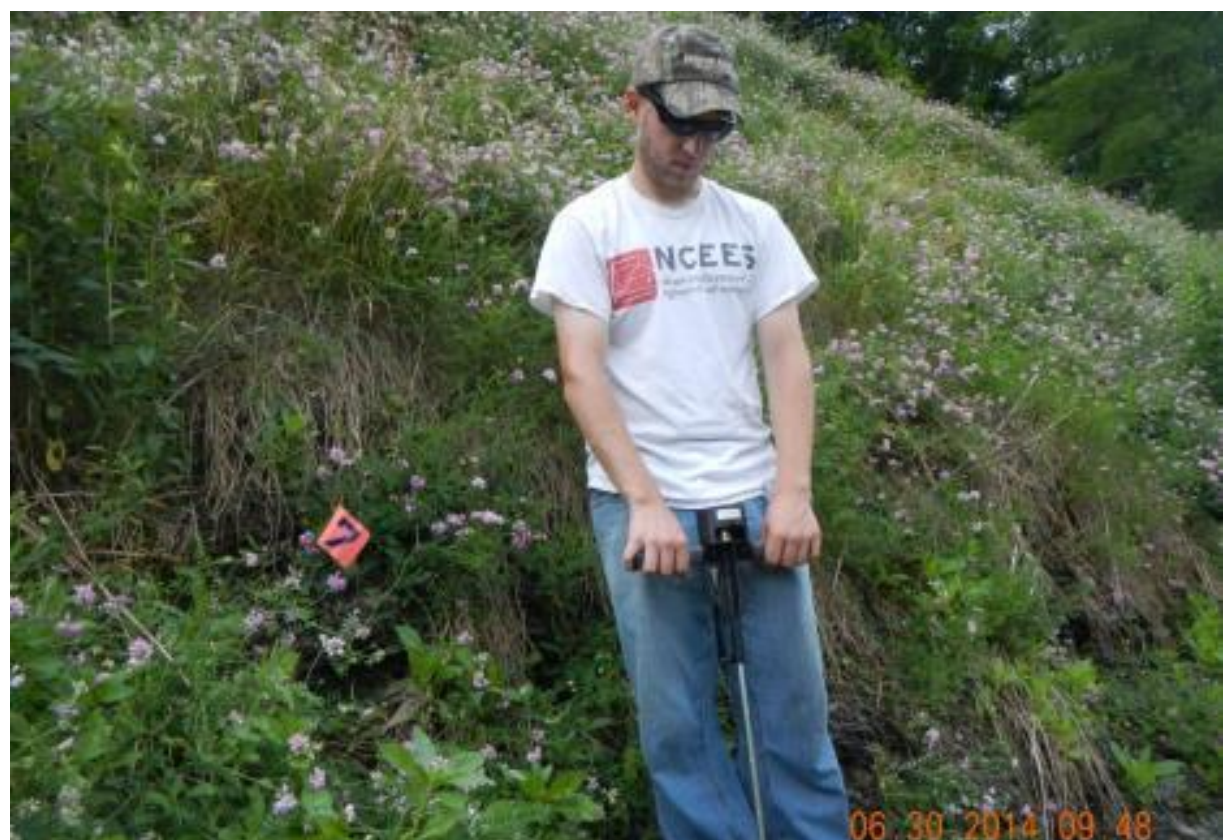

Figure 60: Compaction testing at Philippi Bypass 


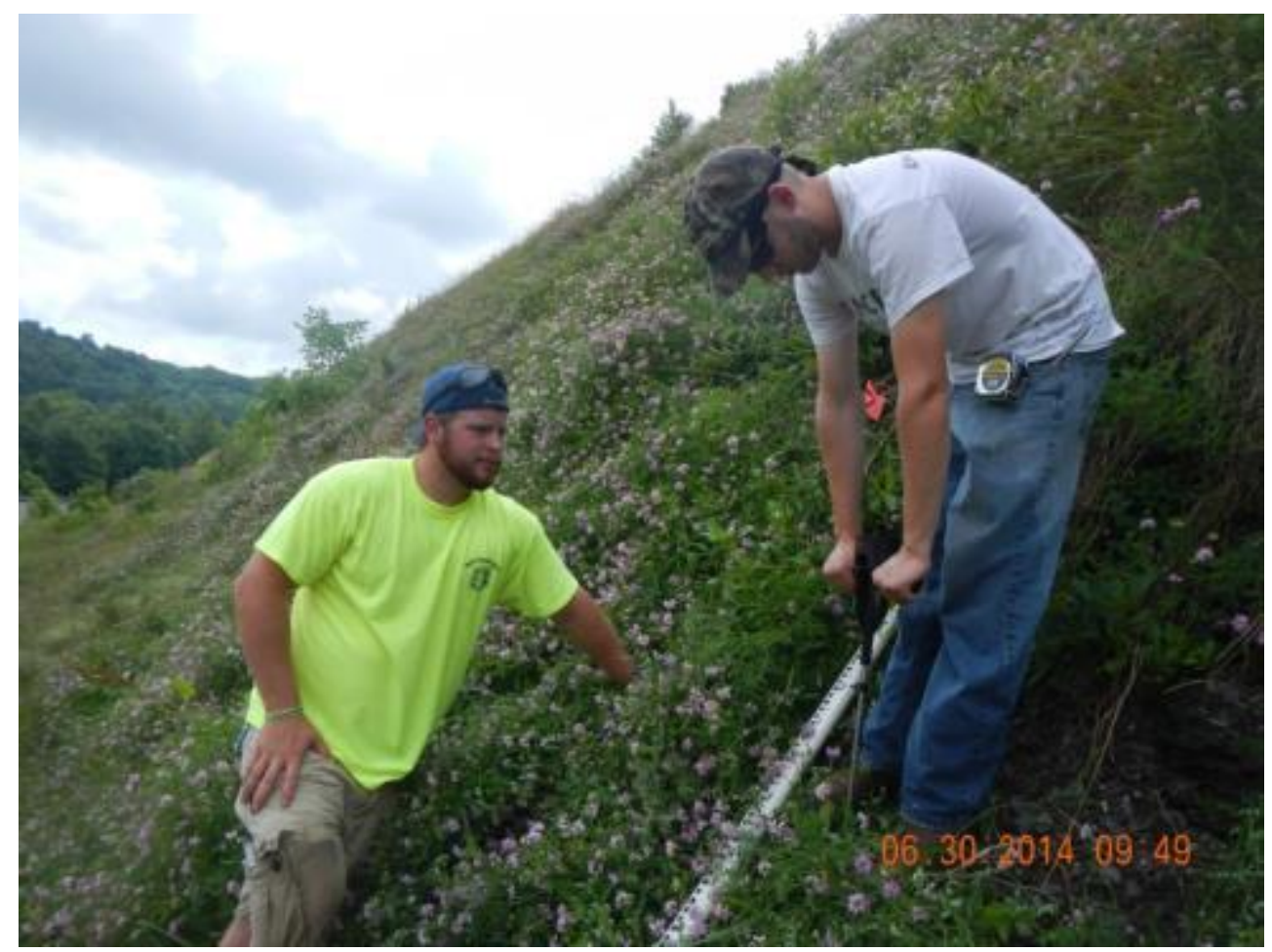

Figure 61: Compaction testing with penetrometer at Philippi Bypass

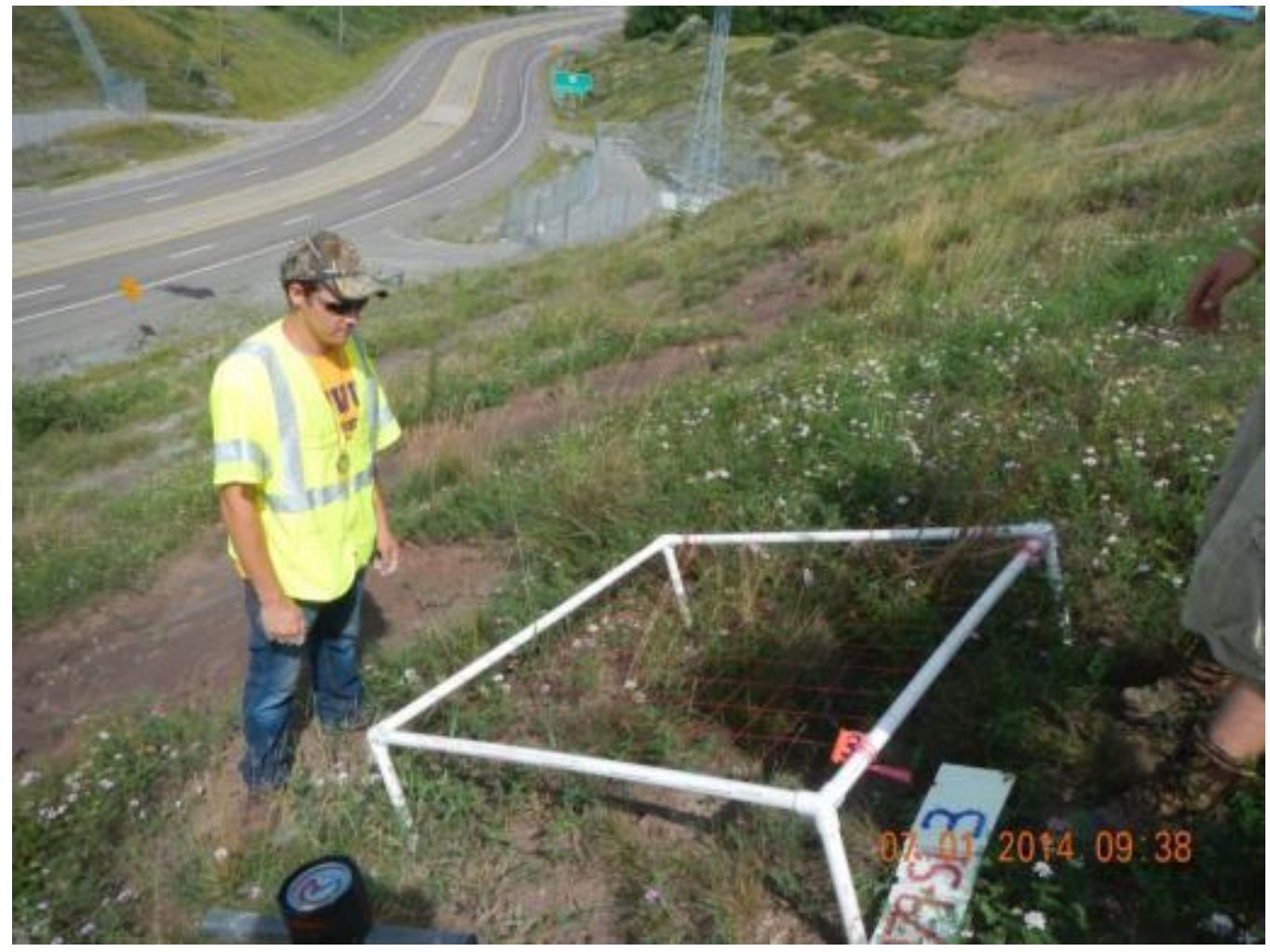

Figure 62: PPF evaluation at 279 Interchange 


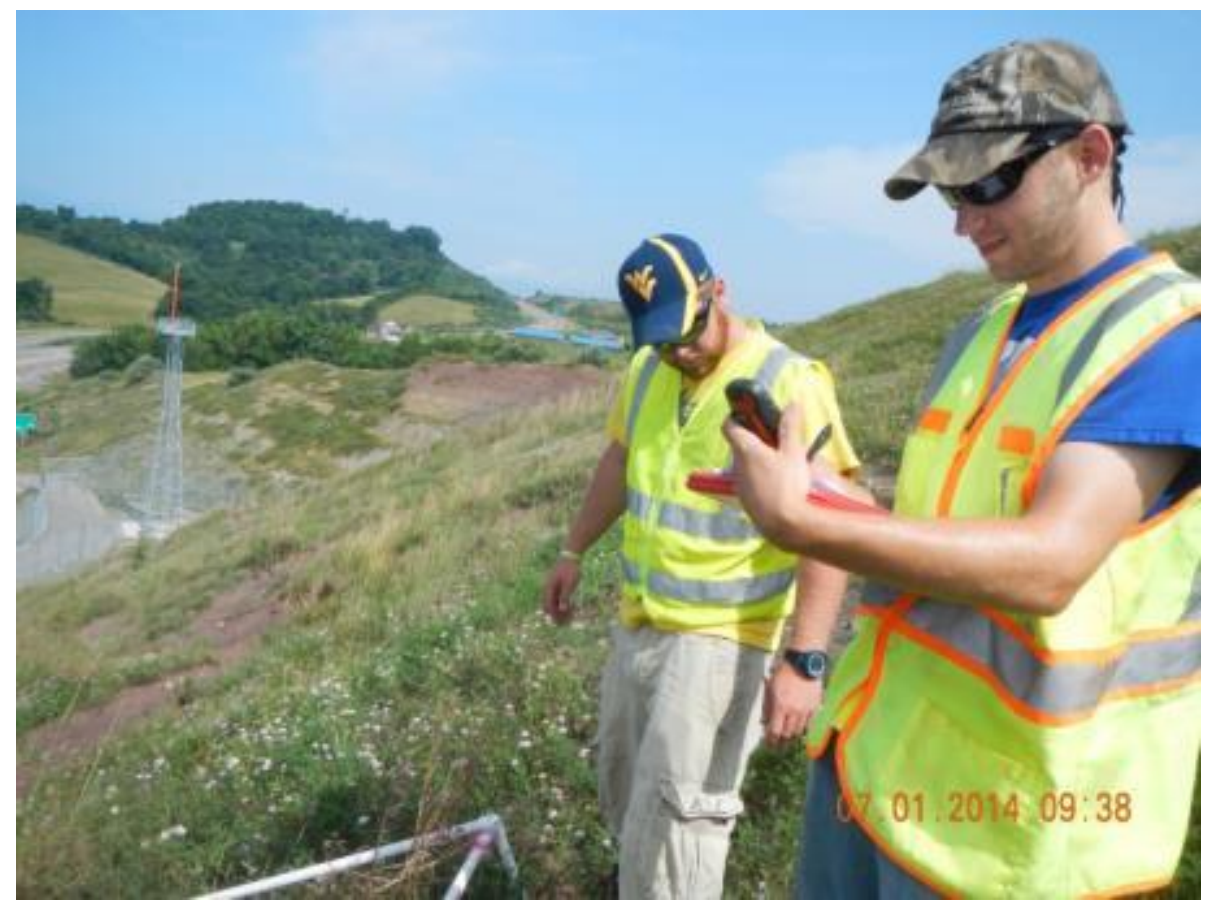

Figure 63: Data recording at 279 Interchange

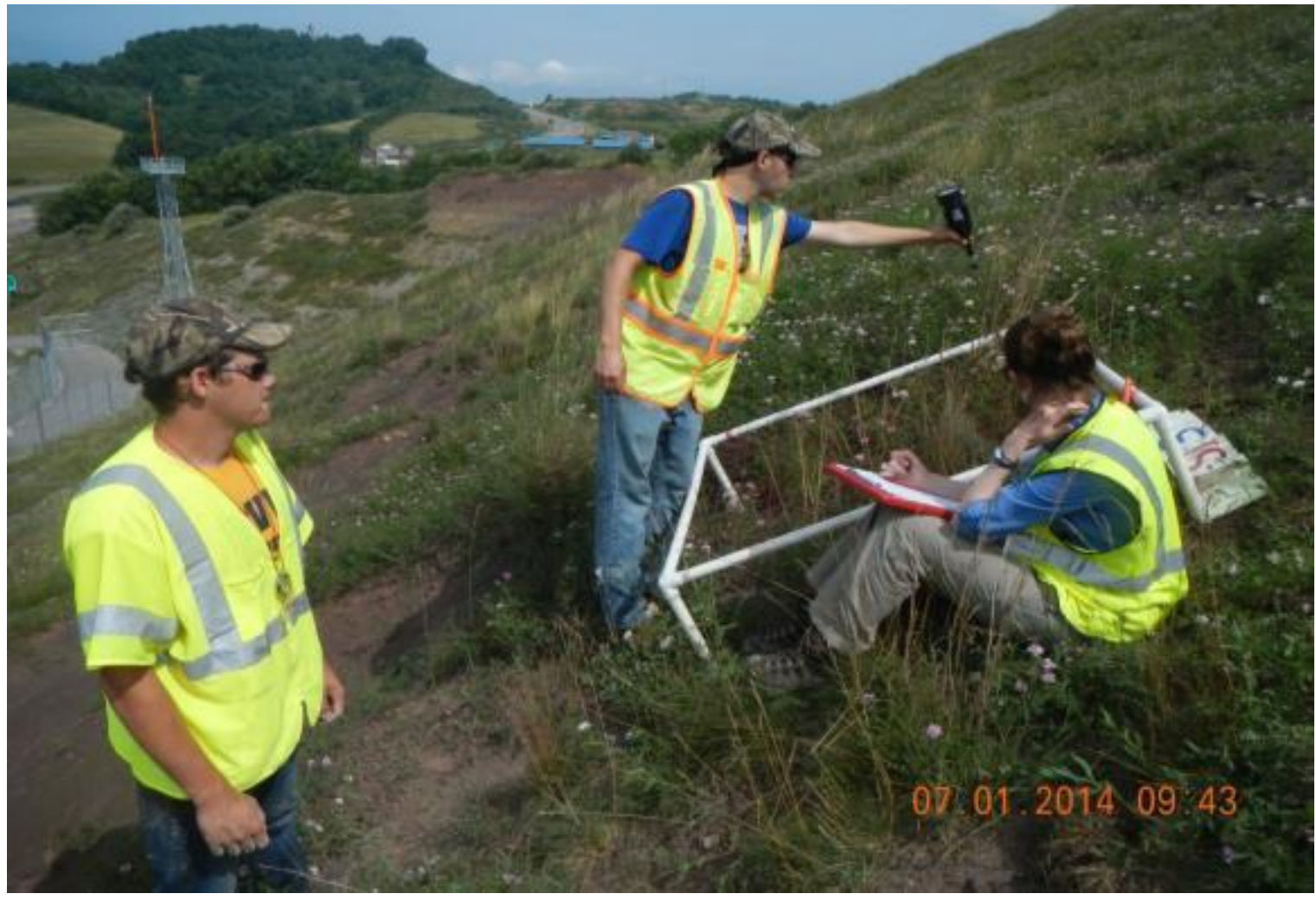

Figure 64: PPF evaluation at 279 Interchange 


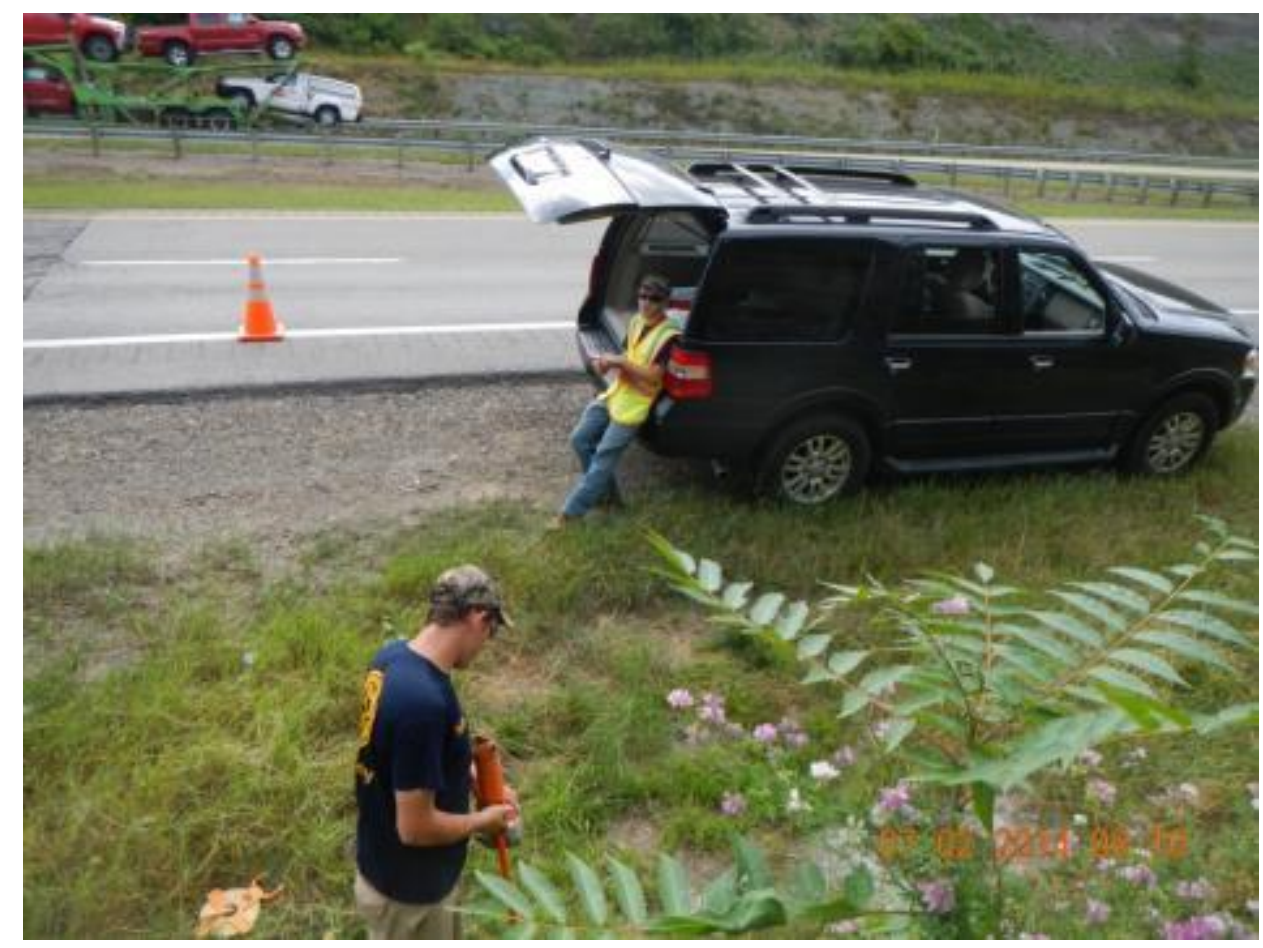

Figure 65: Soil sample collection at Mon-Fayette Expressway Site 1

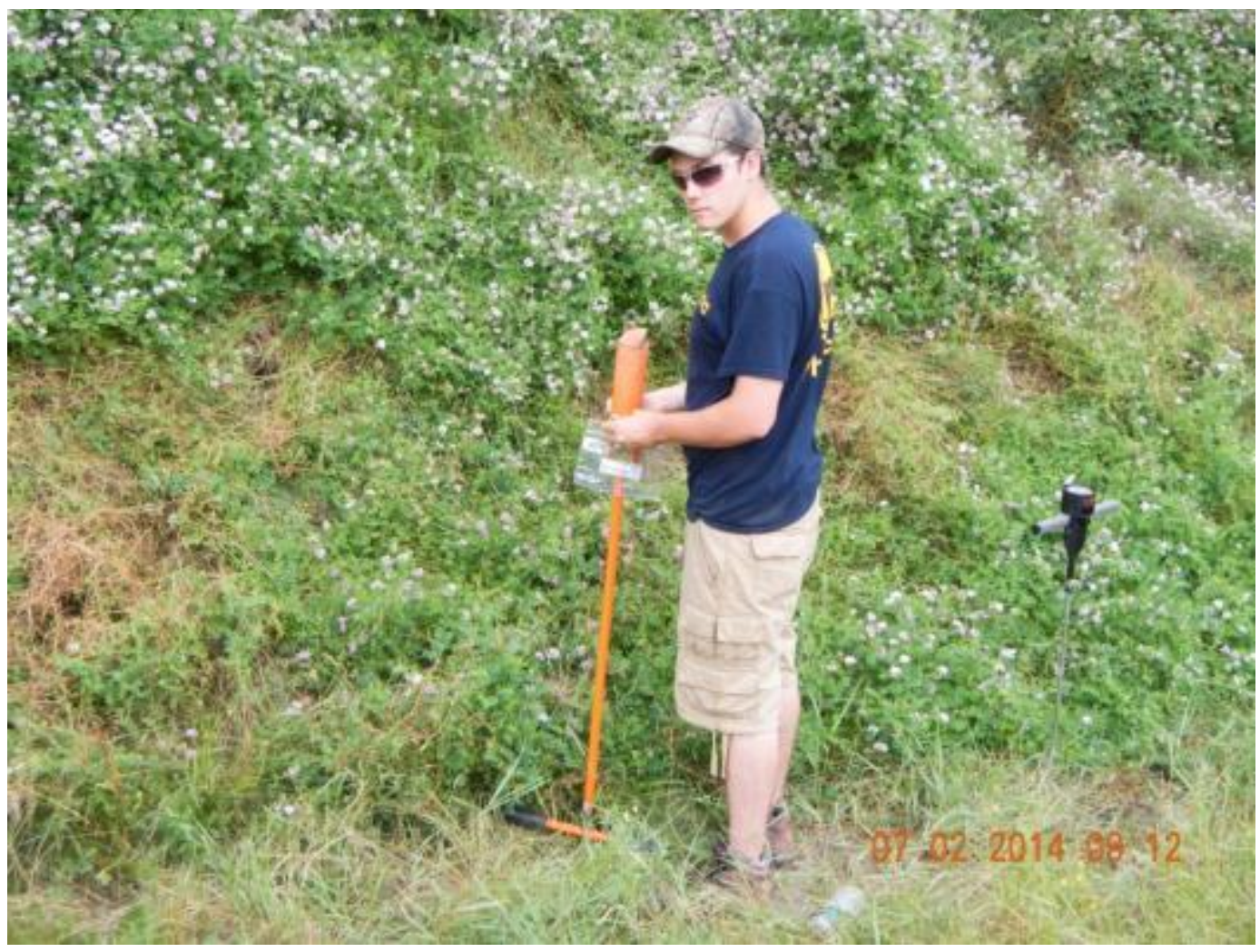

Figure 66: Soil sample collection at Mon-Fayette Expressway Site 1 


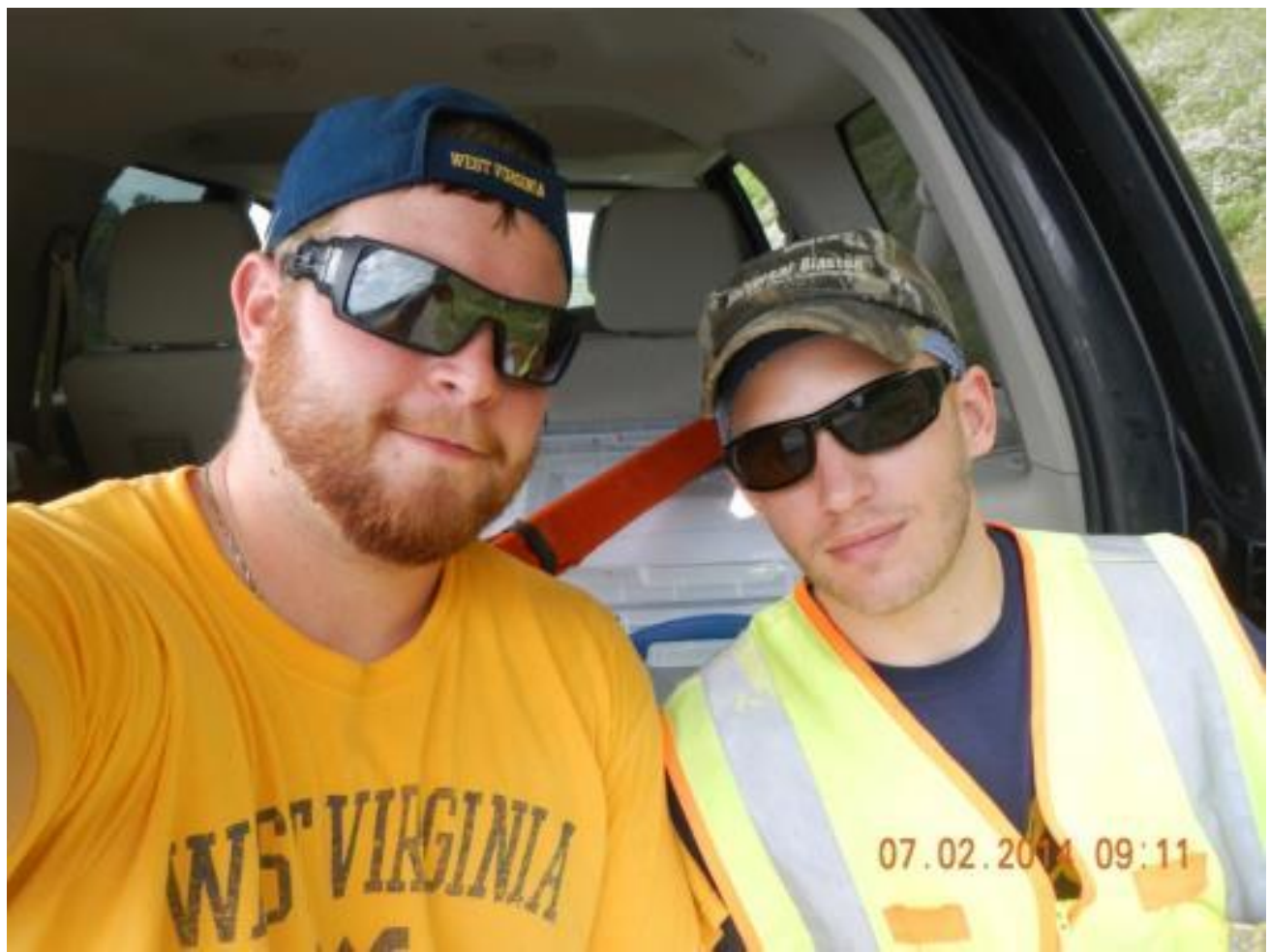

Figure 67: Researcher photograph concluding data collection at Mon-Fayette Expressway Site 1

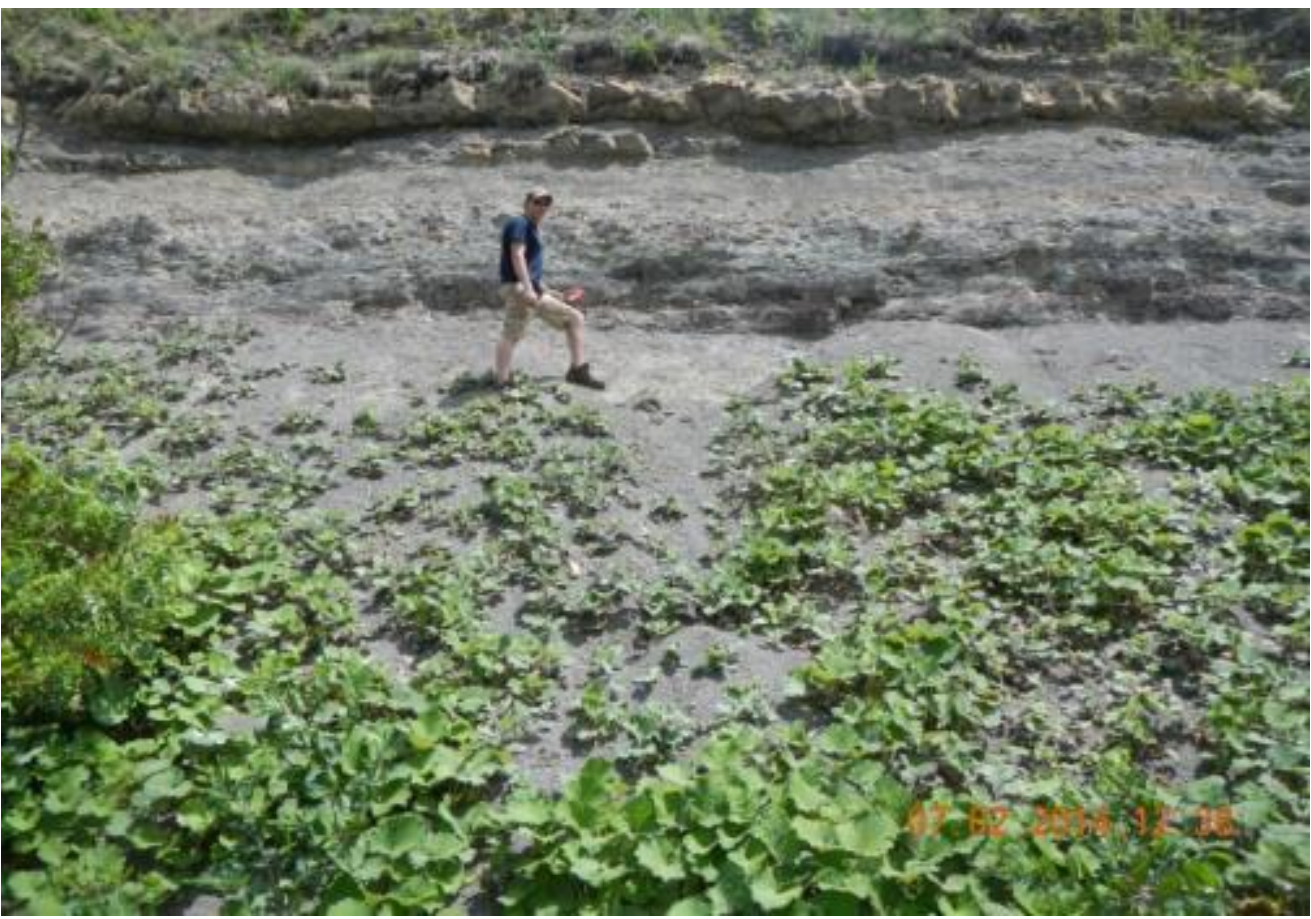

Figure 68: Random selection of sub-site locations at Mon-Fayette Expressway Site 2 


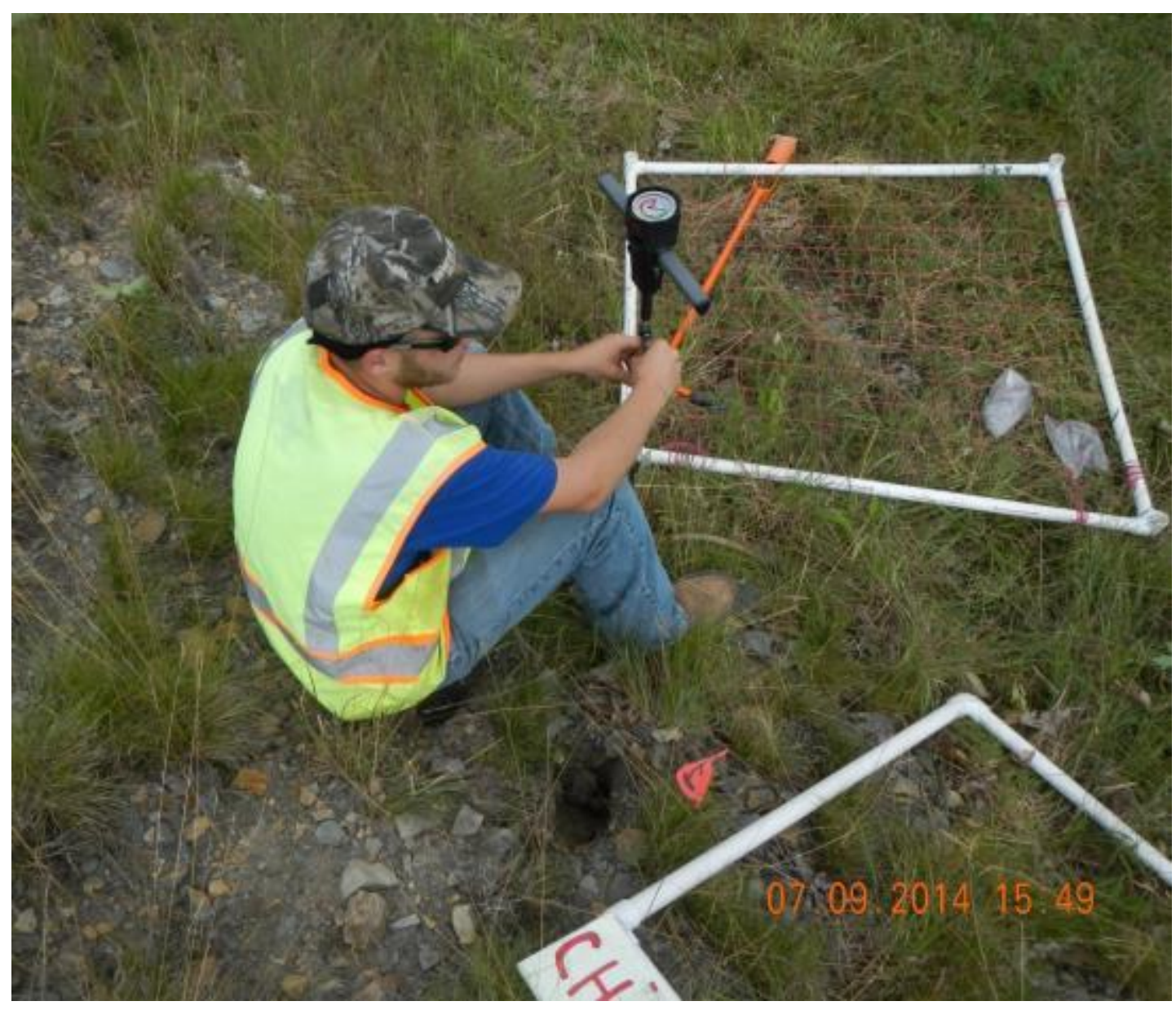

Figure 69: Preparing for compaction test at Corridor H Site 2

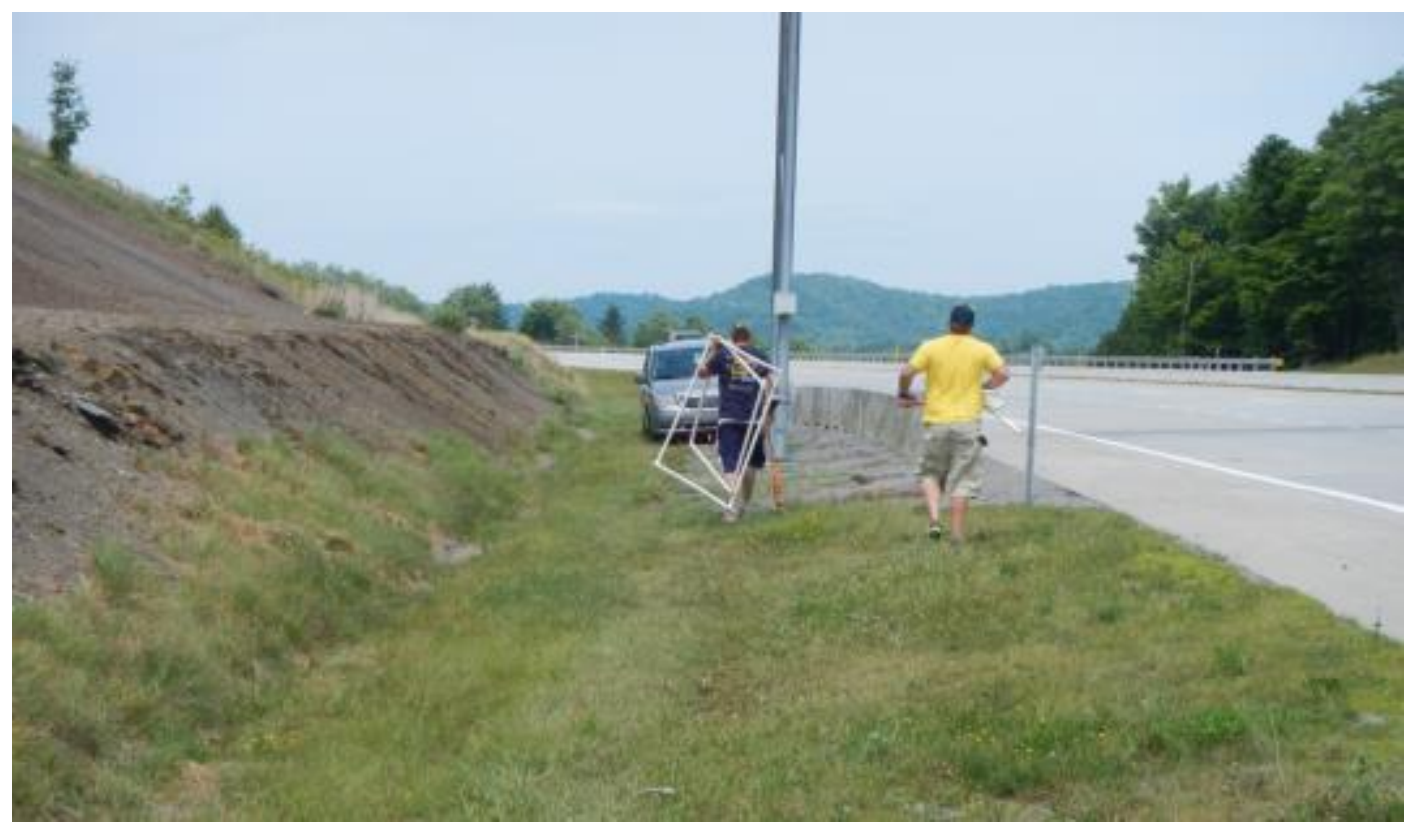

Figure 70: Equipment return concluding site evaluation at Corridor H Site 1 


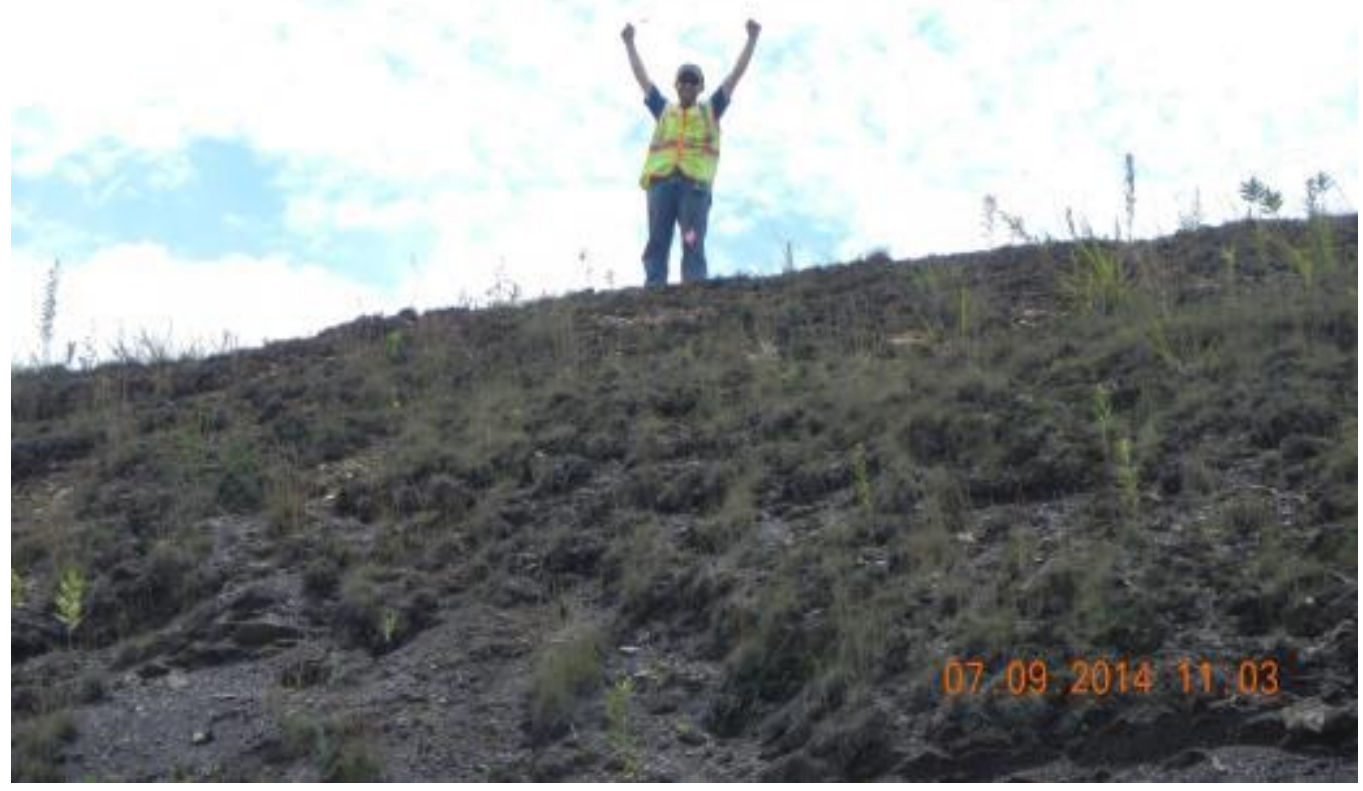

Figure 71: Random site selection at Corridor H Site 2

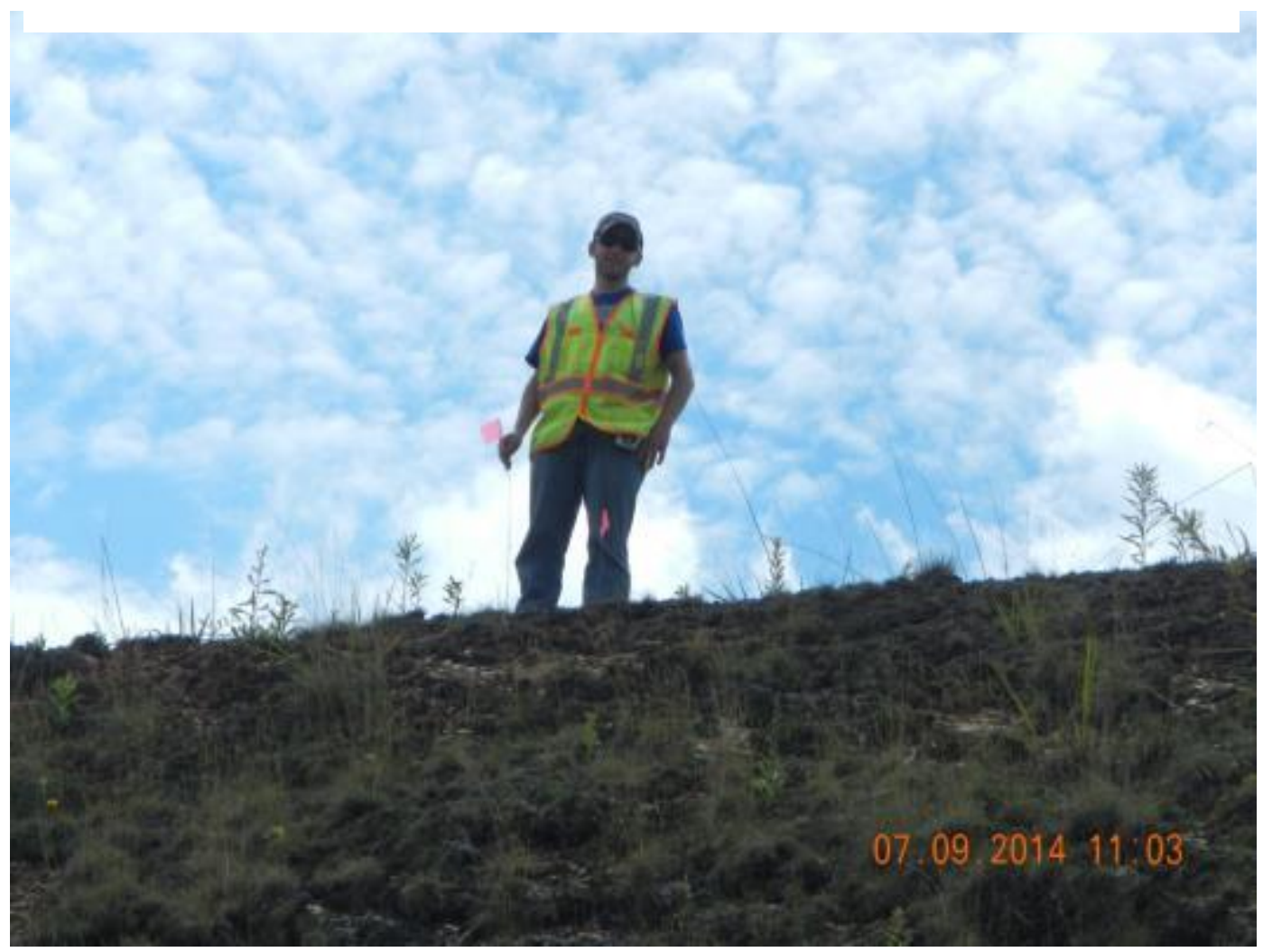

Figure 72: Random site selection at Corridor H Site 2 


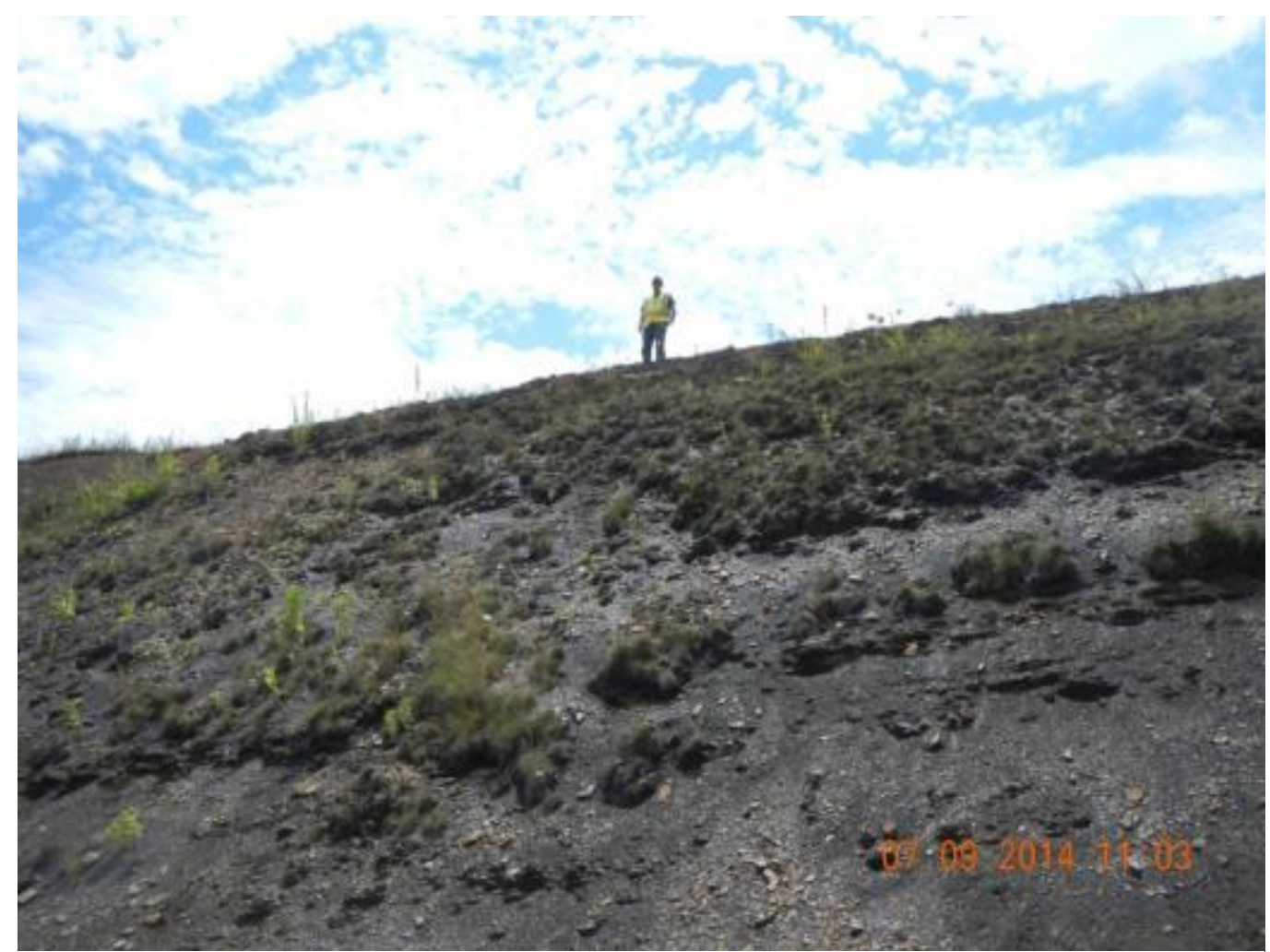

Figure 73: Random site location at Corridor H Site 2

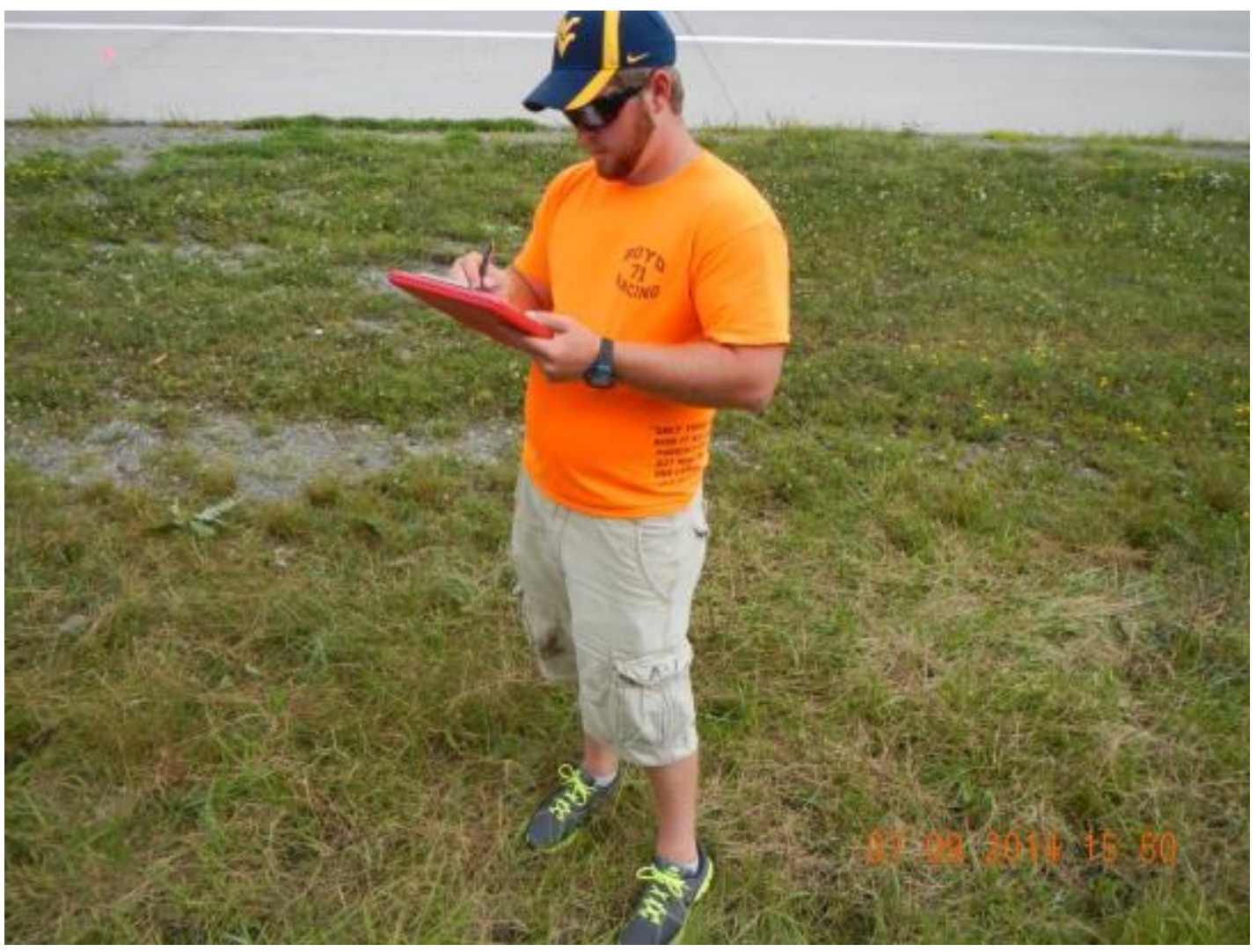

Figure 74: Data recording at Corridor H Site 2 


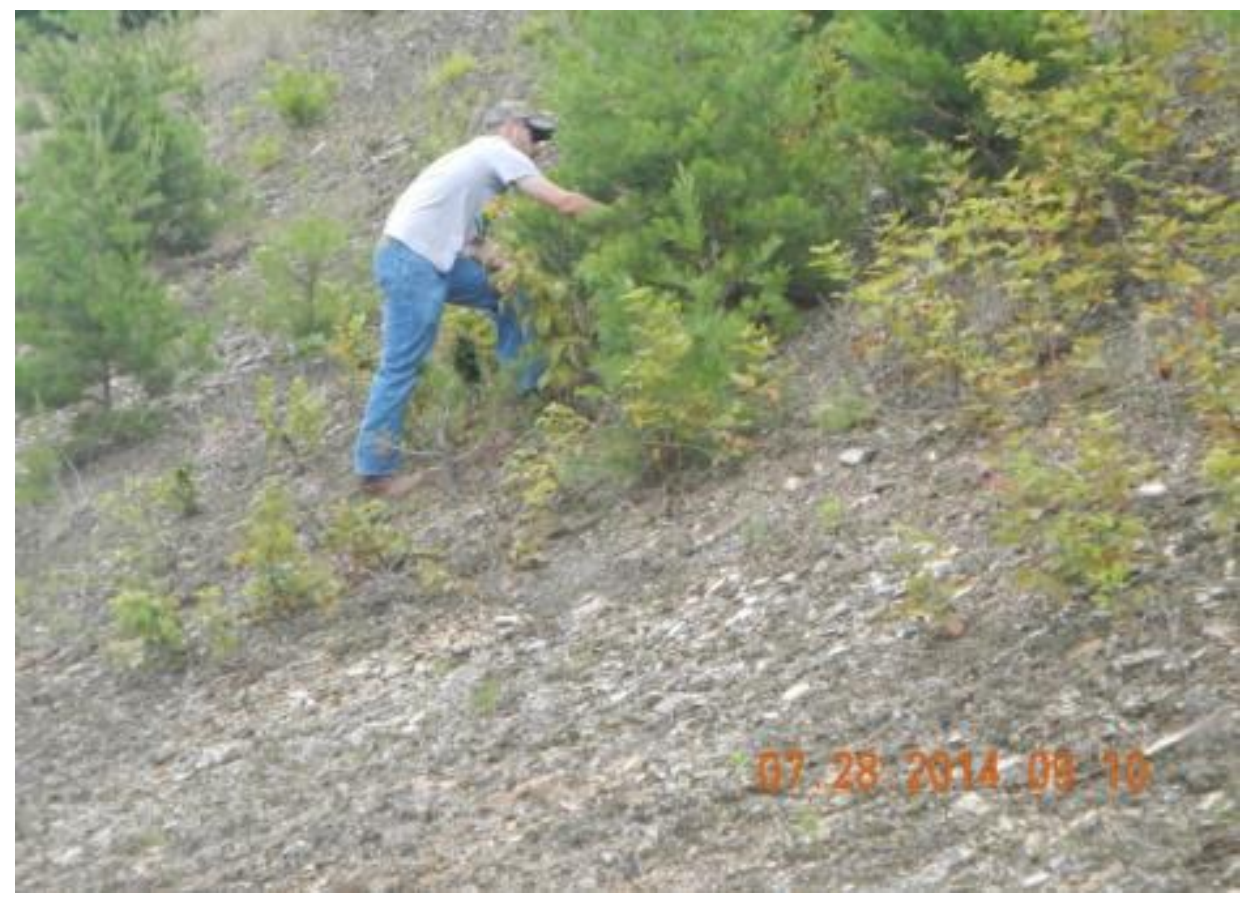

Figure 75: Site perimeter location at Corridor H Site 4

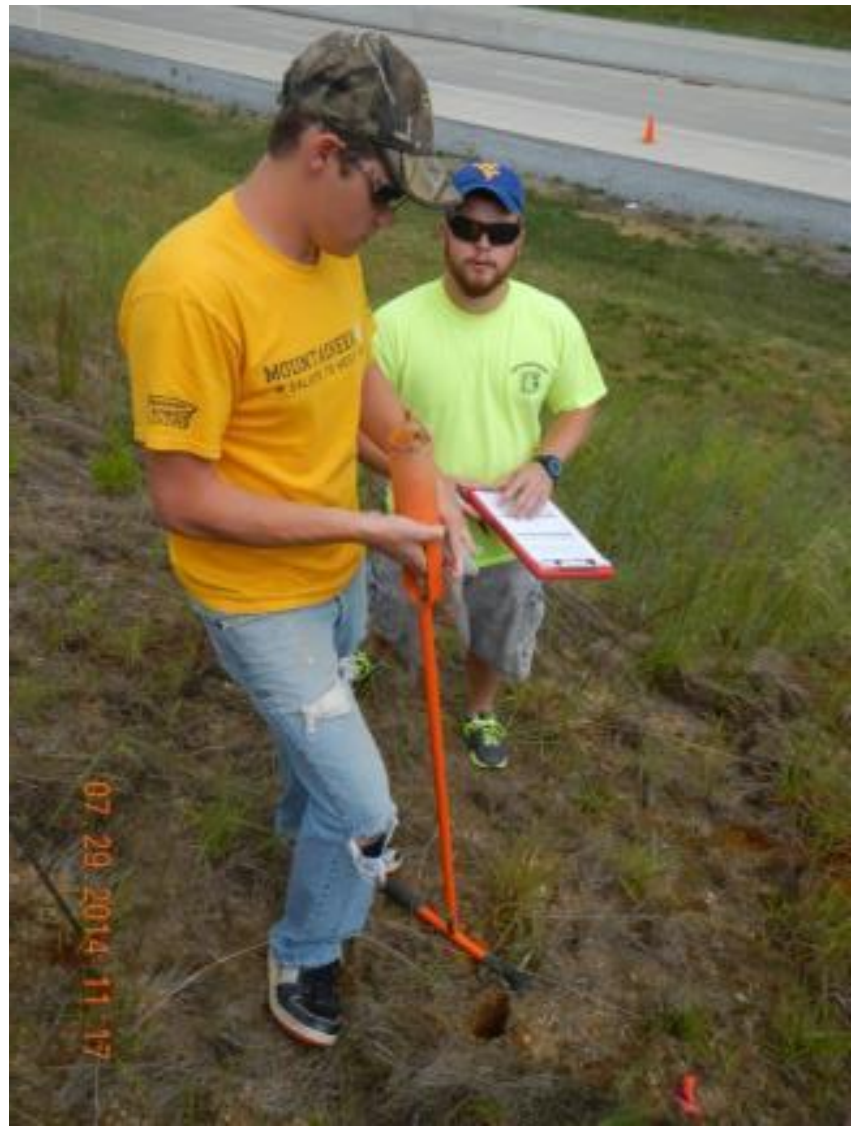

Figure 76: Soil sample collection at Route 9 Site 1 


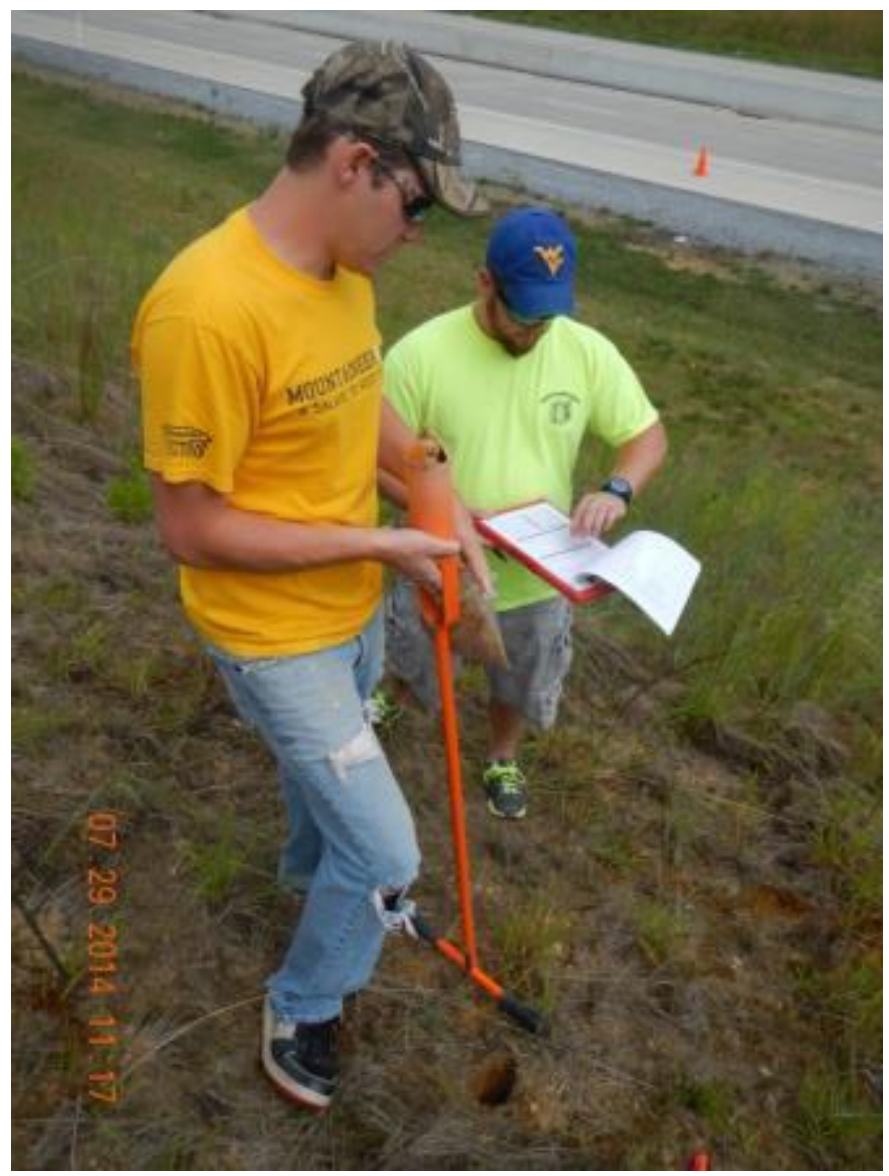

Figure 77: Recording of soil texture at Route 9 Site 1

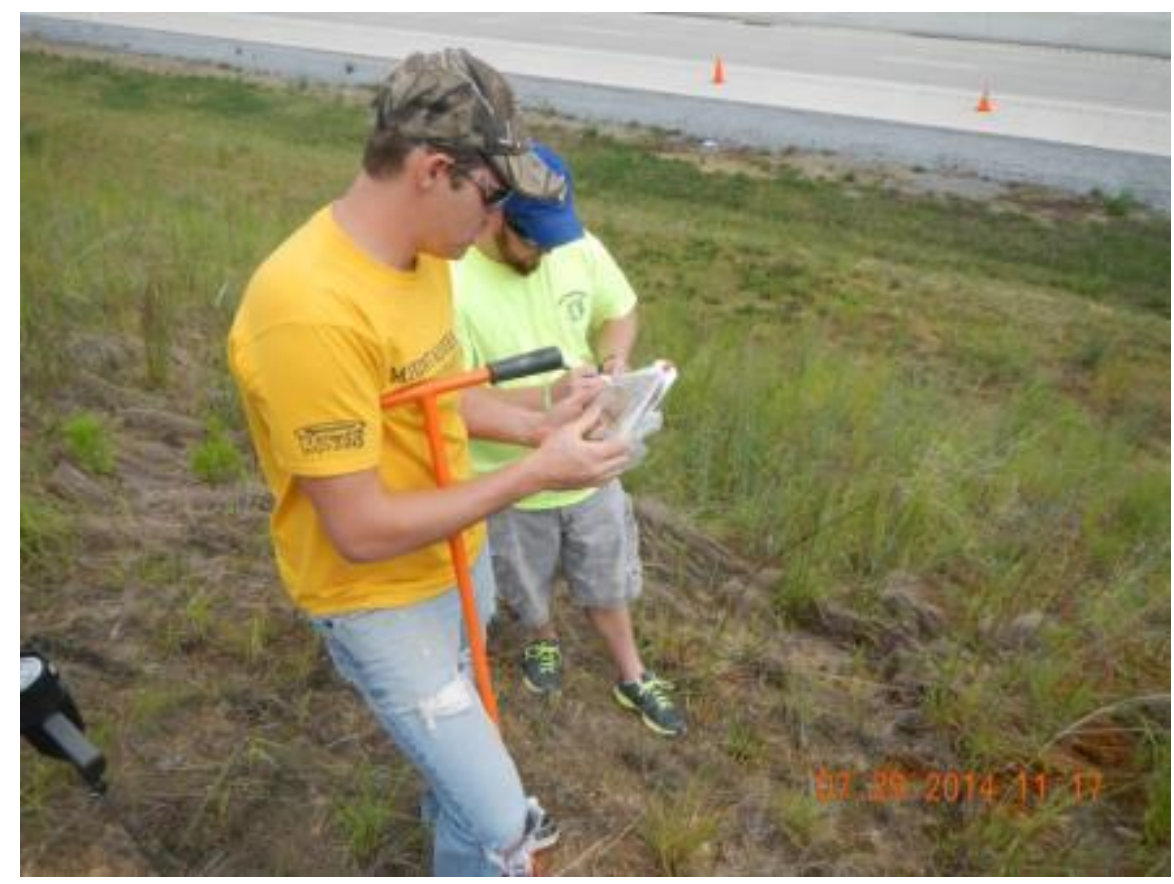

Figure 78: Recording of soil consistency at Route 9 Site 1 


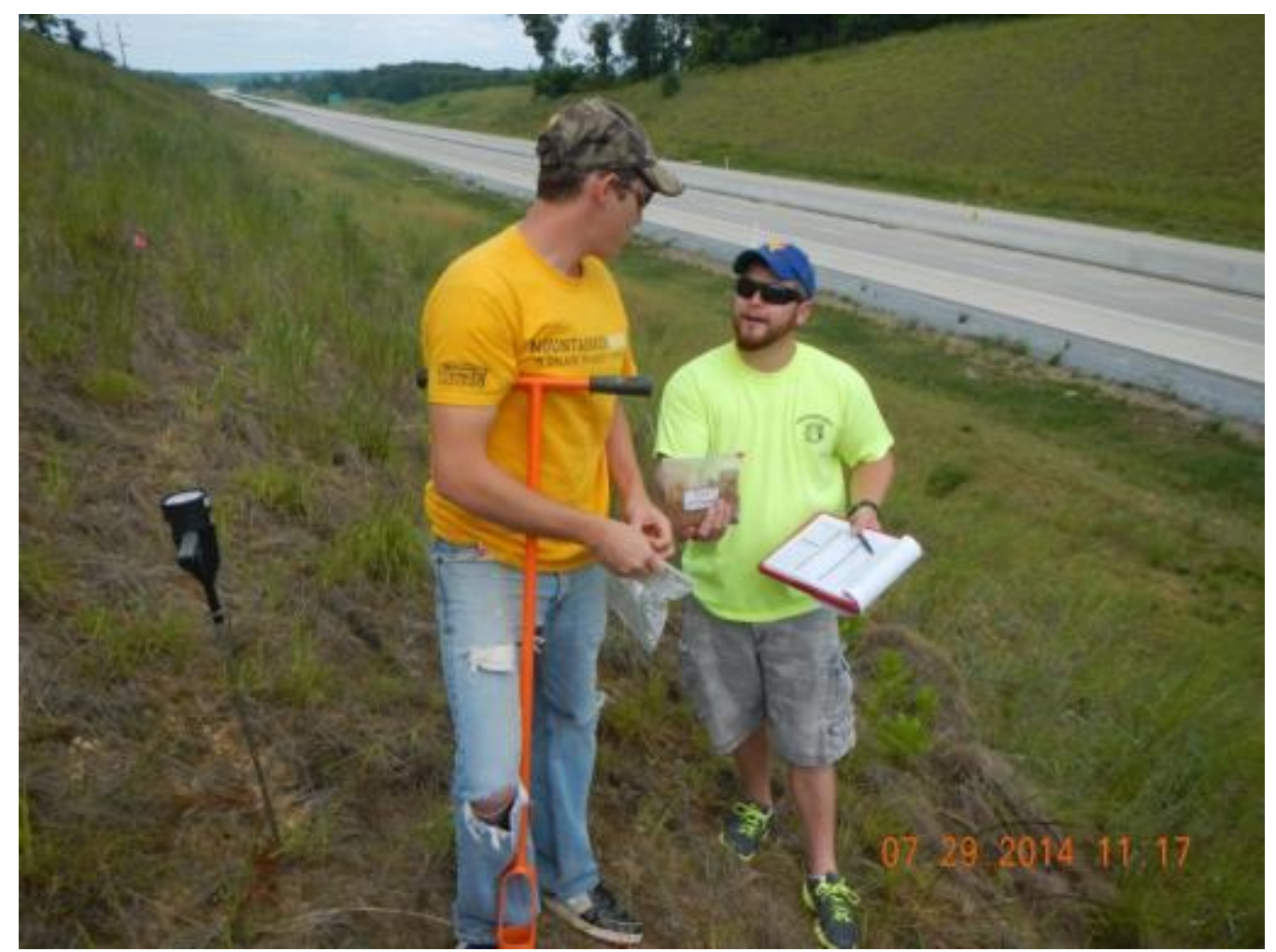

Figure 79: Soil sample collection at Route 9 Site 1

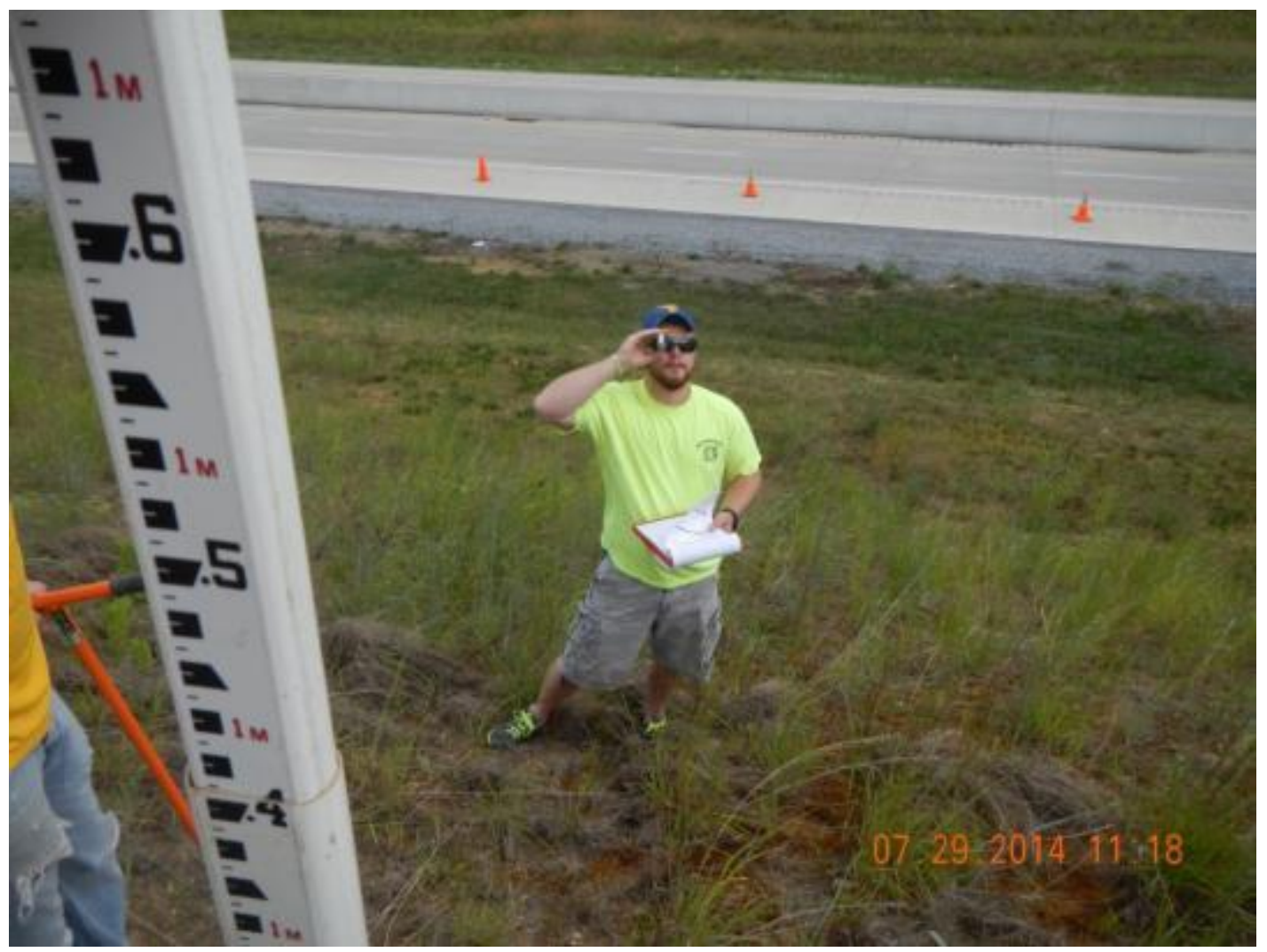

Figure 80: Measurement of slope with clinometer at Route 9 Site 1 


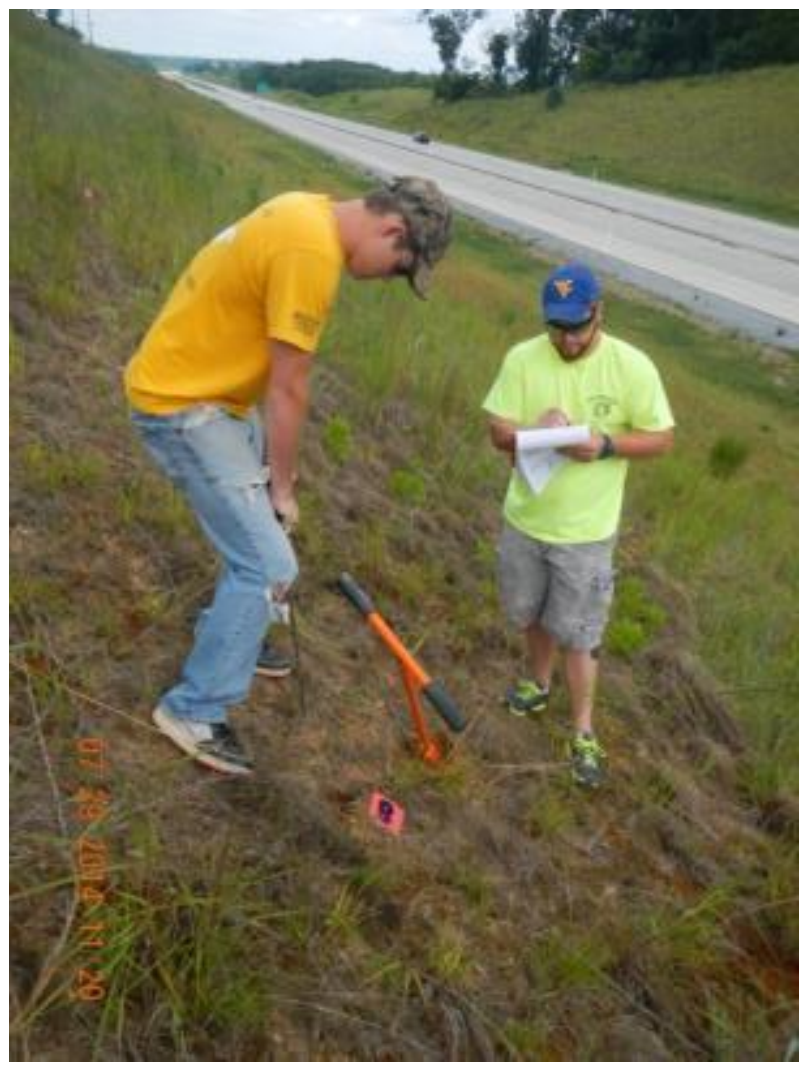

Figure 81: Compaction testing with penetrometer at Route 9 Site 1

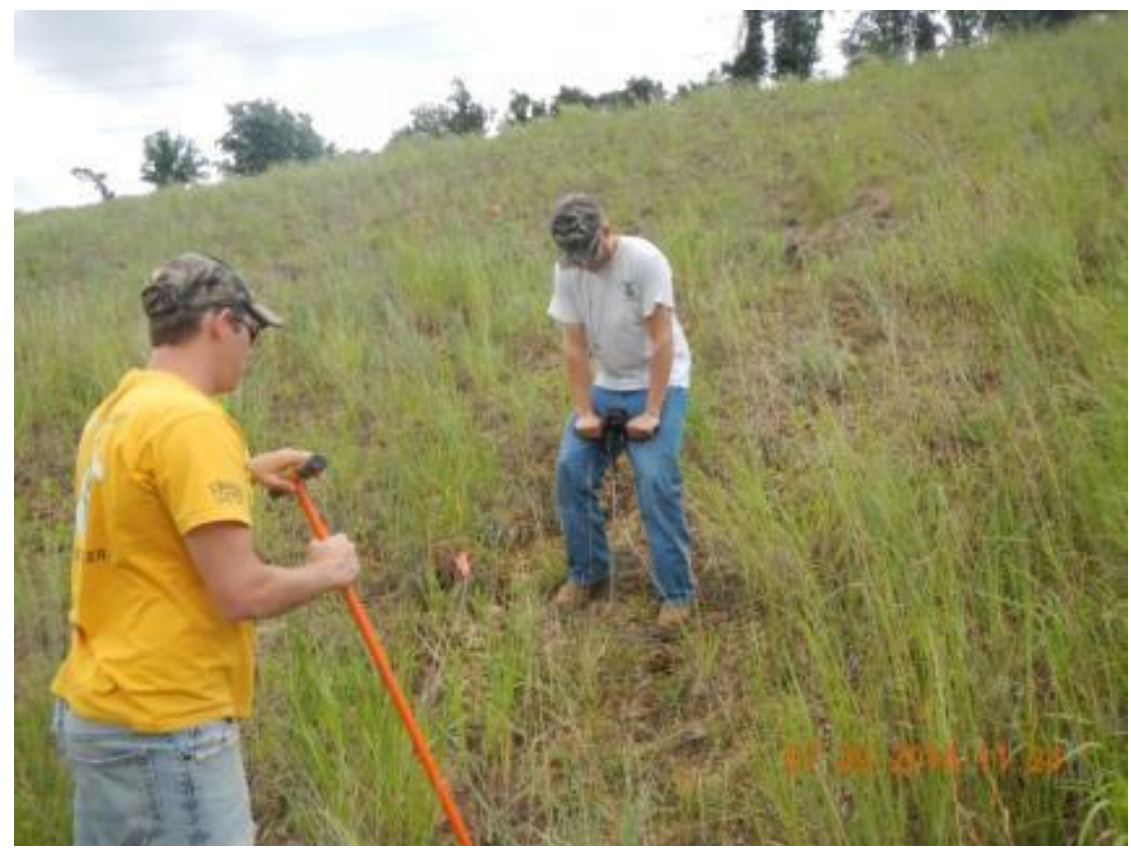

Figure 82: Compaction testing with penetrometer at Route 9 Site 1 


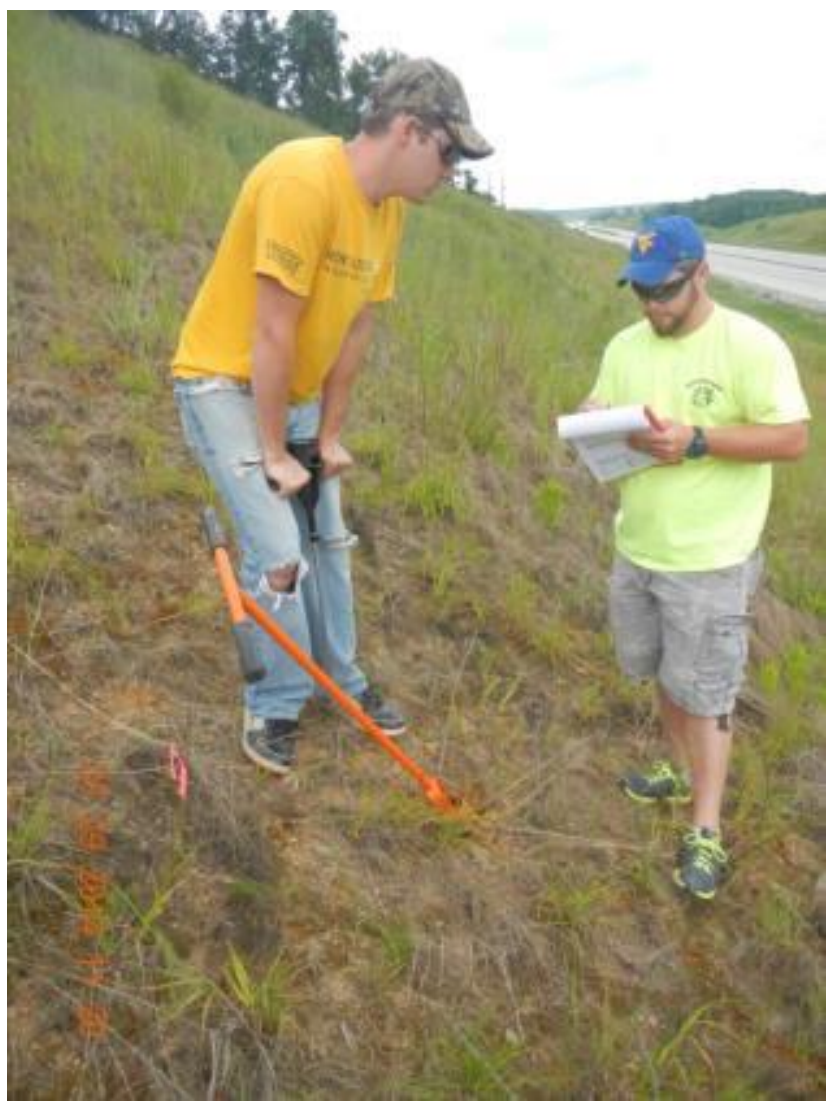

Figure 83: Compaction testing with penetrometer at Route 9 Site 1

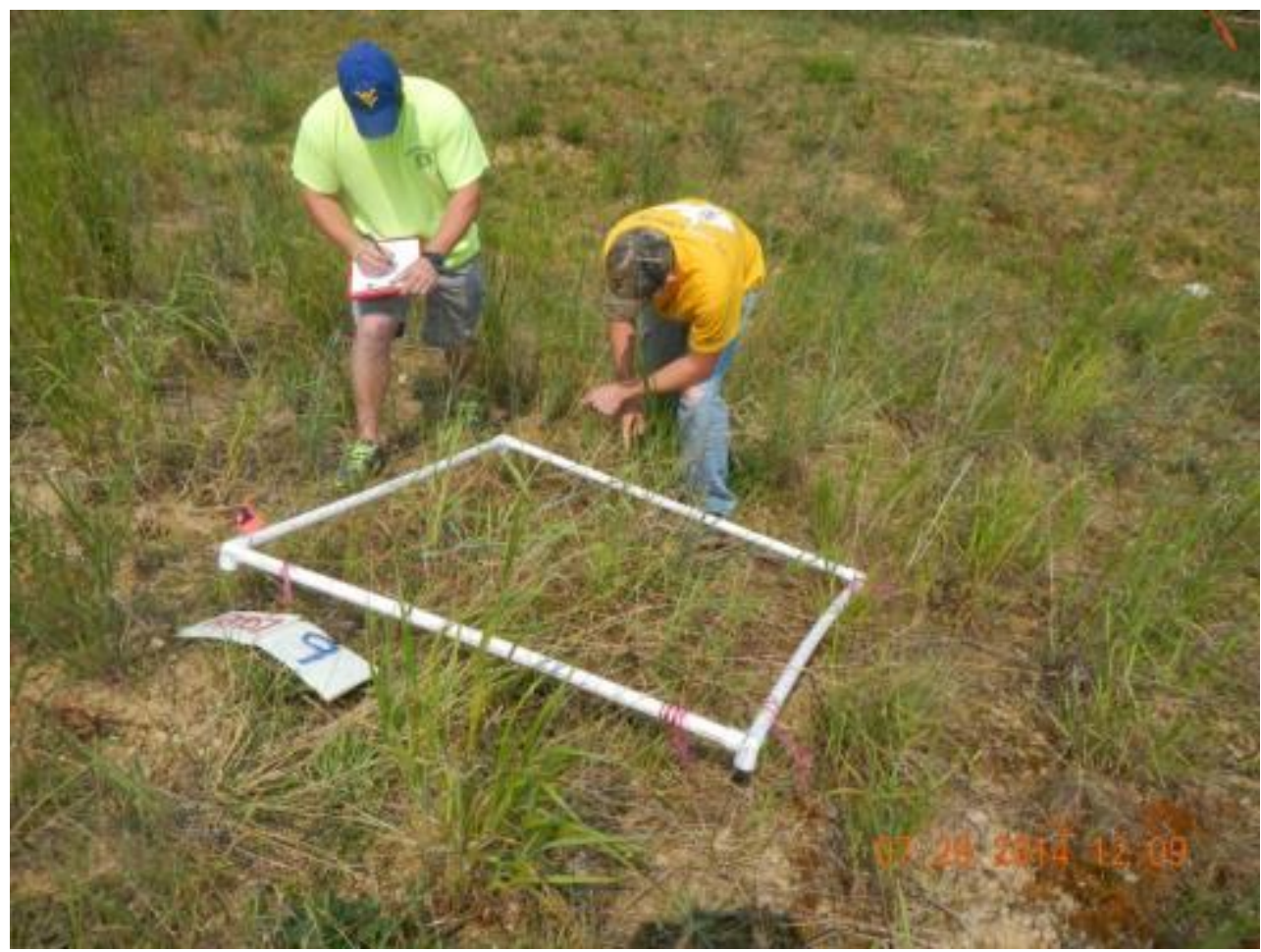

Figure 84: PPF evaluation at Route 9 Site 1 


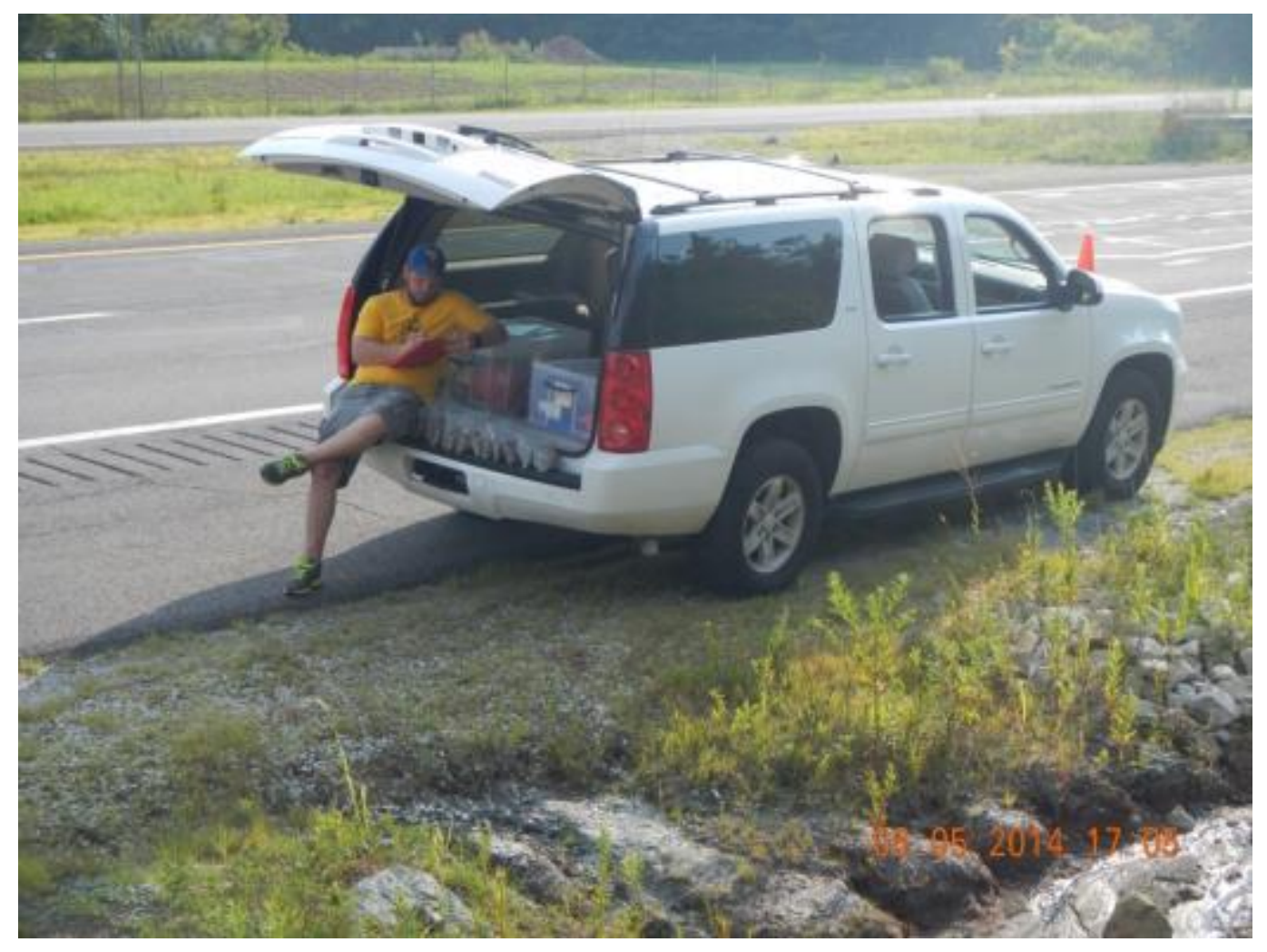

Figure 85: Data recording at Route 193

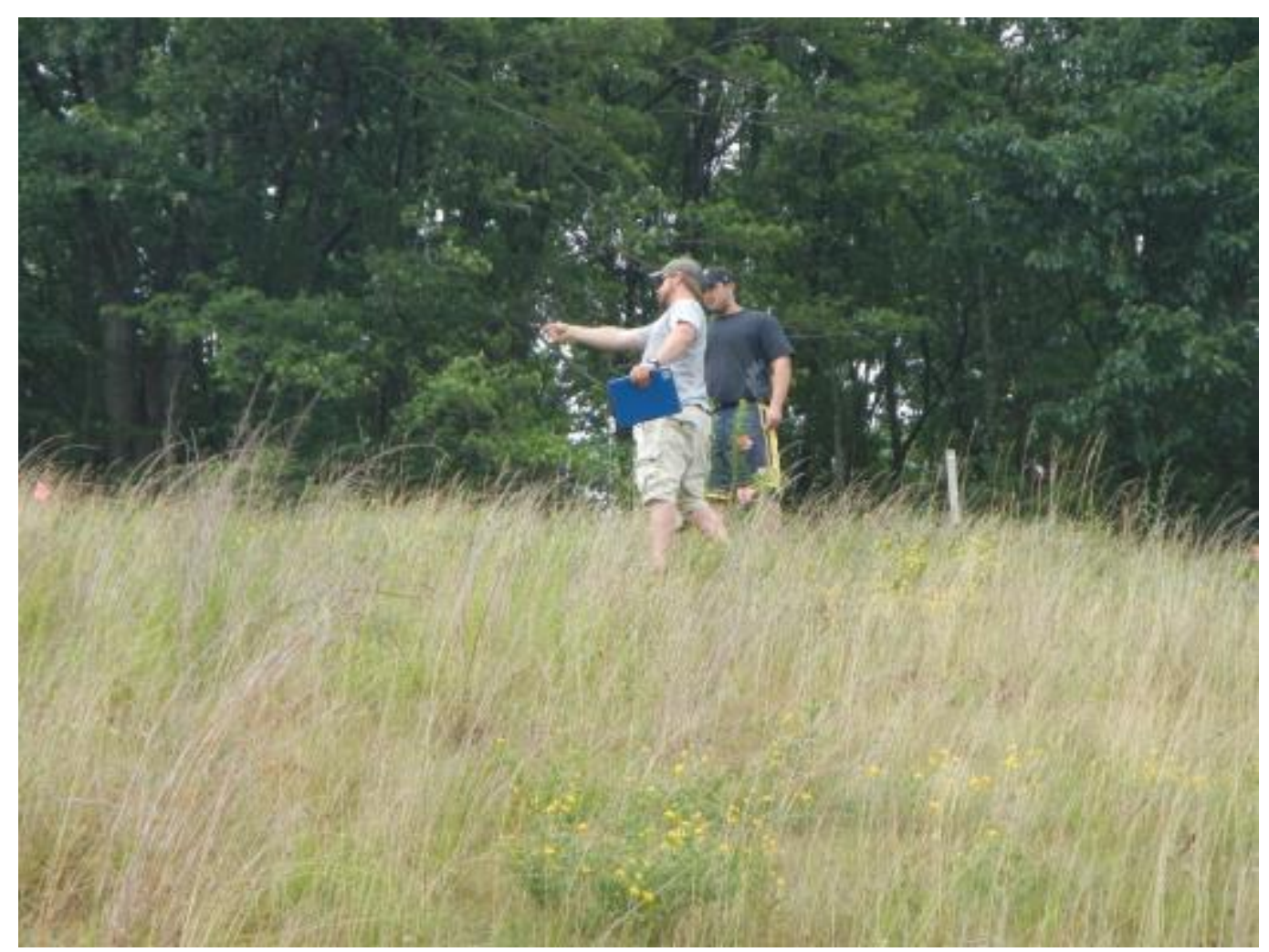

Figure 86: Random plot selection at East Beckley Bypass 


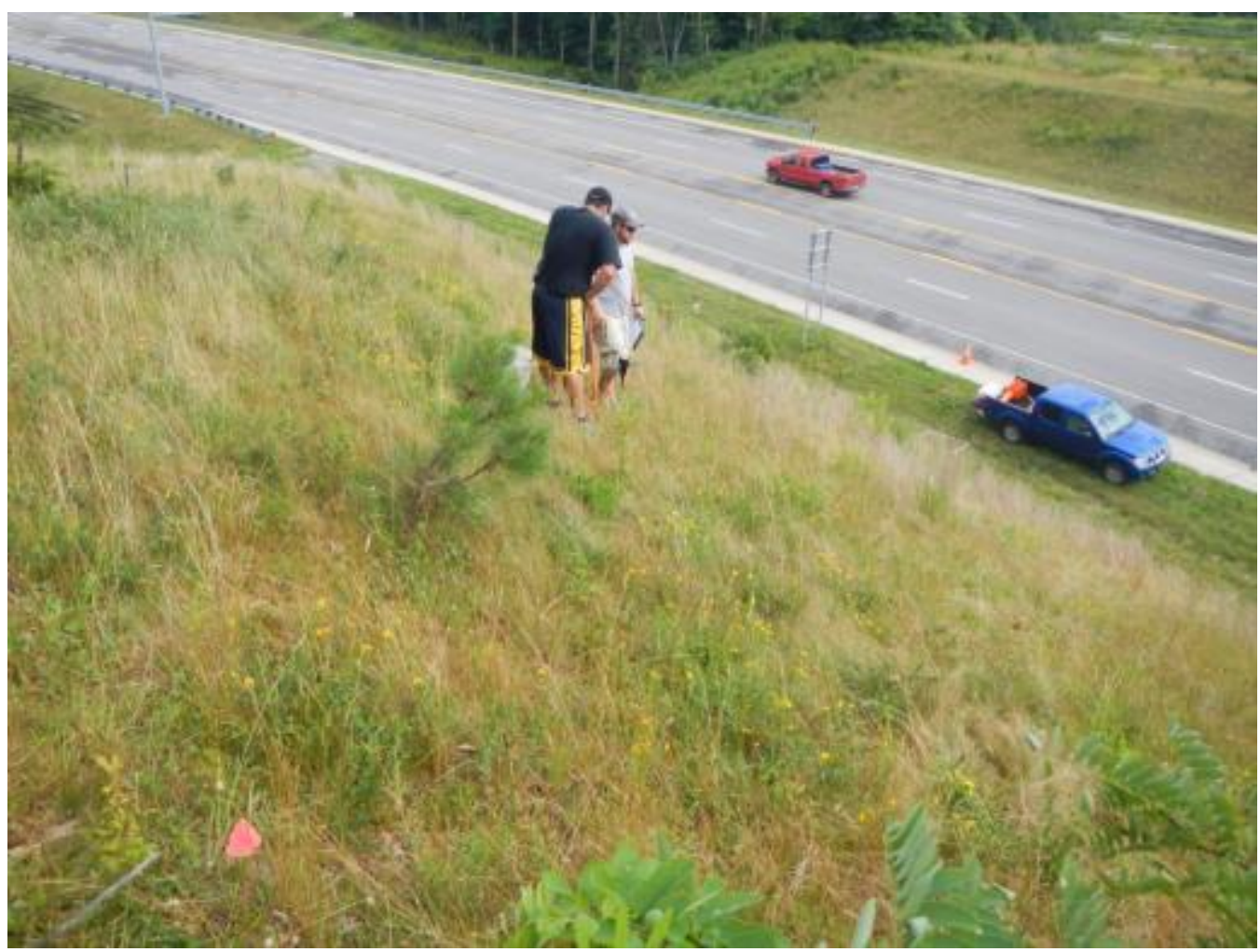

Figure 87: Soil sample collection at East Beckley Bypass

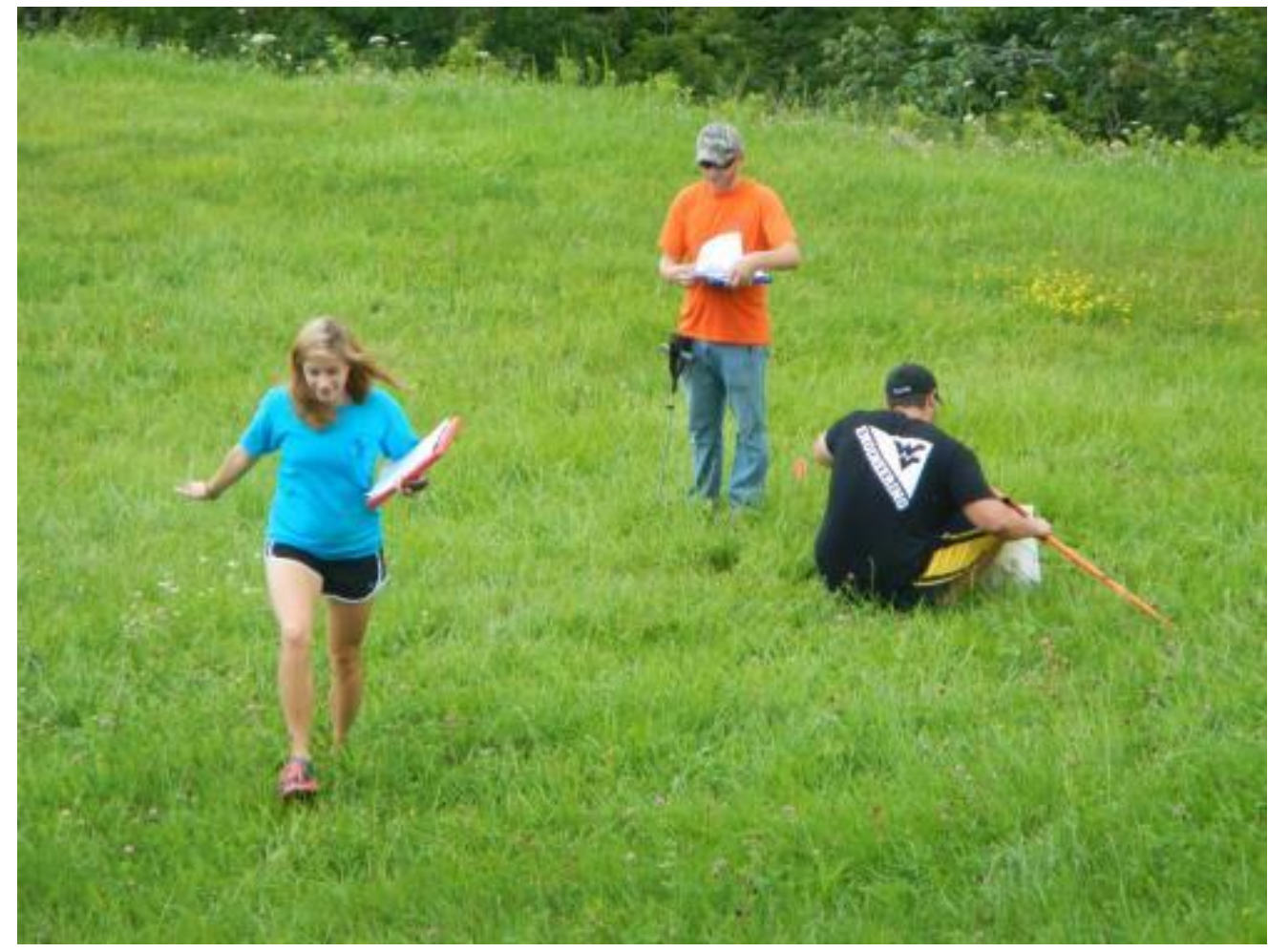

Figure 88: Data collection at Route 19 


\subsection{Appendix C: Raw Data and Results}

Table 14: Composite of all field testing results

\begin{tabular}{|c|c|c|c|c|c|c|c|c|c|c|c|c|c|c|c|}
\hline Site & Subplot & $\begin{array}{c}\text { Percent } \\
\text { Cover } \\
(\%)\end{array}$ & $\mathrm{pH}$ & $\begin{array}{l}\text { Clay } \\
\text { (\%) }\end{array}$ & $\begin{array}{c}\text { Sand } \\
(\%)\end{array}$ & $\begin{array}{l}\text { Silt } \\
(\%)\end{array}$ & $\begin{array}{l}\text { OM } \\
\text { (\%) }\end{array}$ & $\begin{array}{c}\mathrm{N} \\
(\mathrm{mg} / \mathrm{kg})\end{array}$ & $\begin{array}{c}\mathrm{P} \\
(\mathrm{mg} / \mathrm{kg})\end{array}$ & $\begin{array}{c}\mathrm{K} \\
(\mathrm{mg} / \mathrm{kg})\end{array}$ & $\begin{array}{l}\text { Soluble Salts } \\
(\mathrm{mmhos} / \mathrm{cm})\end{array}$ & $\begin{array}{c}\text { Aspect } \\
\left({ }^{\circ}\right)\end{array}$ & $\begin{array}{c}\text { Slope } \\
(\%)\end{array}$ & $\begin{array}{c}\text { Cation } \\
\text { Exchange } \\
\text { Capacity (CEC) } \\
\text { (meq } / 100 \mathrm{~g})\end{array}$ & $\begin{array}{c}\text { Elevation } \\
(\mathrm{ft})\end{array}$ \\
\hline \multirow{5}{*}{ SMN } & 1 & 50 & \multirow{5}{*}{8.4} & \multirow{5}{*}{14.4} & \multirow{5}{*}{51.6} & \multirow{5}{*}{34} & \multirow{5}{*}{1.5} & \multirow{5}{*}{3} & \multirow{5}{*}{10} & \multirow{5}{*}{133} & \multirow{5}{*}{0.5} & \multirow{5}{*}{243} & \multirow{5}{*}{39} & \multirow{5}{*}{27.2} & \multirow{5}{*}{622} \\
\hline & 2 & 100 & & & & & & & & & & & & & \\
\hline & 3 & 96 & & & & & & & & & & & & & \\
\hline & 4 & 95 & & & & & & & & & & & & & \\
\hline & 5 & 100 & & & & & & & & & & & & & \\
\hline \multirow{5}{*}{ SMS } & 6 & 49 & \multirow{5}{*}{8.0} & \multirow{5}{*}{32.4} & \multirow{5}{*}{31.6} & \multirow{5}{*}{36} & \multirow{5}{*}{1.3} & \multirow{5}{*}{1} & \multirow{5}{*}{4} & \multirow{5}{*}{125} & \multirow{5}{*}{0.4} & \multirow{5}{*}{245} & \multirow{5}{*}{37} & \multirow{5}{*}{23.1} & \multirow{5}{*}{643} \\
\hline & 7 & 92 & & & & & & & & & & & & & \\
\hline & 8 & 71 & & & & & & & & & & & & & \\
\hline & 9 & 72 & & & & & & & & & & & & & \\
\hline & 10 & 50 & & & & & & & & & & & & & \\
\hline \multirow{10}{*}{ FGC } & 1 & 96 & & & & & & & & & & & & & \\
\hline & 2 & 95 & & & & & & & & & & & & & \\
\hline & 3 & 10 & & & & & & & & & & & & & \\
\hline & 4 & 92 & & & & & & & & & & & & & \\
\hline & 5 & 62 & 60 & 271 & 176 & 30 & 24 & 2 & 16 & 87 & 081 & 207 & 2? & 151 & 1110 \\
\hline & 6 & 100 & 0.0 & 22.4 & 41.0 & (50 & 2.4 & 2 & 10 & 81 & 0.81 & 282 & 22 & 13.4 & 1110 \\
\hline & 7 & 85 & & & & & & & & & & & & & \\
\hline & 8 & 34 & & & & & & & & & & & & & \\
\hline & 9 & 91 & & & & & & & & & & & & & \\
\hline & 10 & 80 & & & & & & & & & & & & & \\
\hline & 1 & 89 & & & & & & & & & & & & & \\
\hline 47INTa & 2 & 33 & 9.6 & 16.4 & 37.6 & 46 & 1 & 1 & 5 & 153 & 1.04 & 247 & 19 & 20.6 & 631 \\
\hline & 3 & 77 & & & & & & & & & 1.04 & & & 2.0 & \\
\hline & 4 & 73 & & & & & & & & & & & & & \\
\hline
\end{tabular}




\begin{tabular}{|c|c|c|c|c|c|c|c|c|c|c|c|c|c|c|c|}
\hline & 5 & 16 & & & & & & & & & & & & & \\
\hline \multirow{5}{*}{ 47INTb } & 6 & 54 & \multirow{5}{*}{9.3} & \multirow{5}{*}{18.4} & \multirow{5}{*}{47.6} & \multirow{5}{*}{34} & \multirow{5}{*}{1} & \multirow{5}{*}{2} & \multirow{5}{*}{2} & \multirow{5}{*}{160} & \multirow{5}{*}{1.17} & \multirow{5}{*}{148} & \multirow{5}{*}{6} & \multirow{5}{*}{25.5} & \multirow{5}{*}{633} \\
\hline & 7 & 41 & & & & & & & & & & & & & \\
\hline & 8 & 4 & & & & & & & & & & & & & \\
\hline & 9 & 5 & & & & & & & & & & & & & \\
\hline & 10 & 91 & & & & & & & & & & & & & \\
\hline \multirow{10}{*}{$\mathrm{BH}$} & 1 & 25 & \multirow{10}{*}{9.7} & \multirow{10}{*}{22.4} & \multirow{10}{*}{35.6} & \multirow{10}{*}{42} & \multirow{10}{*}{0.9} & \multirow{10}{*}{1} & \multirow{10}{*}{2} & \multirow{10}{*}{207} & \multirow{10}{*}{1.54} & \multirow{10}{*}{116} & & & \\
\hline & 2 & 17 & & & & & & & & & & & & & \\
\hline & 3 & 45 & & & & & & & & & & & & & \\
\hline & 4 & 49 & & & & & & & & & & & & & \\
\hline & 5 & 11 & & & & & & & & & & & 27 & 28.4 & 682 \\
\hline & 6 & 2 & & & & & & & & & & & & 20.9 & 20 \\
\hline & 7 & 17 & & & & & & & & & & & & & \\
\hline & 8 & 10 & & & & & & & & & & & & & \\
\hline & 9 & 39 & & & & & & & & & & & & & \\
\hline & 10 & 51 & & & & & & & & & & & & & \\
\hline & 1 & 65 & & & & & & & & & & & & & \\
\hline & 2 & 75 & & & & & & & & & & & & & \\
\hline & 3 & 95 & & & & & & & & & & & & & \\
\hline & 4 & 78 & & & & & & & & & & & & & \\
\hline FA & 5 & 79 & 52 & 224 & 476 & 30 & 2 & 1 & 8 & 70 & 0.27 & 177 & 24 & 16.7 & 835 \\
\hline Len & 6 & 59 & 5.2 & 2.11 & & & & & & & & & & & \\
\hline & 7 & 97 & & & & & & & & & & & & & \\
\hline & 8 & 100 & & & & & & & & & & & & & \\
\hline & 9 & 74 & & & & & & & & & & & & & \\
\hline & 10 & 57 & & & & & & & & & & & & & \\
\hline & 1 & 58 & & & & & & & & & & & & & \\
\hline $168 \mathrm{M}$ & 2 & 28 & 8.2 & 24.4 & 41.6 & 34 & 17 & 2 & 17 & 72 & 1.15 & 299 & 1 & 20.3 & 2050 \\
\hline $1001 \mathrm{i}$ & 3 & 48 & 0.2 & 24.4 & 41.0 & 34 & 1.1 & & 1 & 12 & J.1. & כ & 1 & 20.0 & \\
\hline & 4 & 72 & & & & & & & & & & & & & \\
\hline & 1 & 100 & & & & & & & & & & & & & \\
\hline I68WC & 2 & 100 & 6.4 & 18.4 & 47.6 & 34 & 2.7 & 3 & 2 & 72 & 0.3 & 184 & 4 & 9.9 & 2403 \\
\hline & 3 & 100 & & & & & & & & & & & & & \\
\hline
\end{tabular}




\begin{tabular}{|c|c|c|c|c|c|c|c|c|c|c|c|c|c|c|c|}
\hline & 4 & 93 & & & & & & & & & & & & & \\
\hline & 5 & 100 & & & & & & & & & & & & & \\
\hline & 6 & 100 & & & & & & & & & & & & & \\
\hline & 7 & 100 & & & & & & & & & & & & & \\
\hline & 8 & 100 & & & & & & & & & & & & & \\
\hline & 9 & 99 & & & & & & & & & & & & & \\
\hline & 10 & 94 & & & & & & & & & & & & & \\
\hline \multirow{10}{*}{ PB } & 1 & 100 & \multirow{10}{*}{6.3} & \multirow{10}{*}{10.4} & \multirow{10}{*}{51.6} & \multirow{10}{*}{38} & \multirow{10}{*}{2.2} & \multirow{10}{*}{10} & \multirow{10}{*}{8} & \multirow{10}{*}{126} & \multirow{10}{*}{0.23} & \multirow{10}{*}{17} & \multirow{10}{*}{59} & \multirow{10}{*}{9.4} & \multirow{10}{*}{1340} \\
\hline & 2 & 99 & & & & & & & & & & & & & \\
\hline & 3 & 100 & & & & & & & & & & & & & \\
\hline & 4 & 100 & & & & & & & & & & & & & \\
\hline & 5 & 100 & & & & & & & & & & & & & \\
\hline & 6 & 100 & & & & & & & & & & & & & \\
\hline & 7 & 100 & & & & & & & & & & & & & \\
\hline & 8 & 96 & & & & & & & & & & & & & \\
\hline & 9 & 98 & & & & & & & & & & & & & \\
\hline & 10 & 94 & & & & & & & & & & & & & \\
\hline \multirow{4}{*}{$279-1 a$} & 3 & 83 & \multirow{4}{*}{8.0} & \multirow{4}{*}{12.4} & \multirow{4}{*}{71.6} & \multirow{4}{*}{16} & \multirow{4}{*}{1.6} & \multirow{4}{*}{3} & \multirow{4}{*}{3} & \multirow{4}{*}{179} & \multirow{4}{*}{0.32} & \multirow{4}{*}{244} & & & \\
\hline & 4 & 74 & & & & & & & & & & & 15 & 235 & 1176 \\
\hline & 6 & 100 & & & & & & & & & & & 45 & 23.5 & $11 / 6$ \\
\hline & 7 & 77 & & & & & & & & & & & & & \\
\hline & 1 & 3 & & & & & & & & & & & & & \\
\hline & 2 & 90 & & & & & & & & & & & & & \\
\hline 17 1 & 5 & 9 & & & & & & & & & & & & & \\
\hline $279-1 b$ & 8 & 12 & 8.0 & 10.4 & 71.6 & $1 \varepsilon$ & 1.6 & 6 & 2 & 222 & 0.38 & 246 & 47.2 & 26.4 & 1191 \\
\hline & 9 & 84 & & & & & & & & & & & & & \\
\hline & 10 & 83 & & & & & & & & & & & & & \\
\hline & 1 & 97 & & & & & & & & & & & & & \\
\hline & 2 & 48 & & & & & & & & & & & & & \\
\hline & 3 & 71 & & & & & & & & & & & & & \\
\hline 279-2 & 4 & 99 & 5.7 & 22.4 & 49.6 & 2 & 1.8 & 1 & 4 & 125 & 0.31 & 232 & 49.1 & 21.6 & 1115 \\
\hline & 5 & 94 & & & & & & & & & & & & & \\
\hline & 6 & 11 & & & & & & & & & & & & & \\
\hline
\end{tabular}




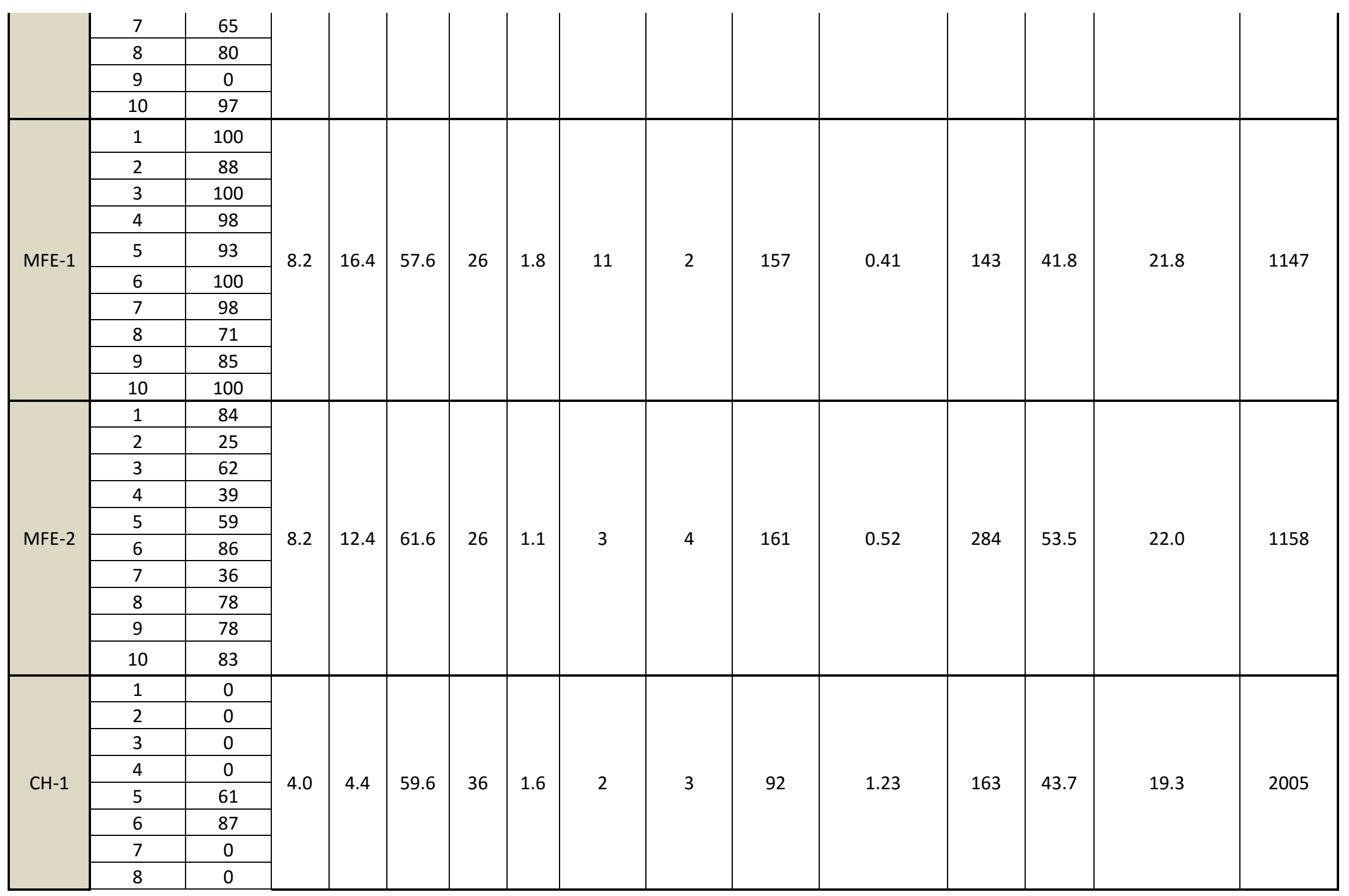




\begin{tabular}{|c|c|c|c|c|c|c|c|c|c|c|c|c|c|c|c|}
\hline & 9 & 0 & & & & & & & & & & & & & \\
\hline & 10 & 0 & & & & & & & & & & & & & \\
\hline \multirow{4}{*}{ CHM-1 } & 1 & 83 & \multirow{4}{*}{7.6} & \multirow{4}{*}{14.4} & \multirow{4}{*}{57.6} & \multirow{4}{*}{28} & \multirow{4}{*}{1.7} & \multirow{4}{*}{4} & \multirow{4}{*}{6} & \multirow{4}{*}{75} & \multirow{4}{*}{0.77} & \multirow{4}{*}{248} & \multirow{4}{*}{9.3} & \multirow{4}{*}{18.0} & \multirow{4}{*}{2086} \\
\hline & 2 & 3 & & & & & & & & & & & & & \\
\hline & 3 & 89 & & & & & & & & & & & & & \\
\hline & 4 & 50 & & & & & & & & & & & & & \\
\hline \multirow{5}{*}{$\mathrm{CH}-2 \mathrm{a}$} & 1 & 22 & \multirow{5}{*}{4.8} & \multirow{5}{*}{14.4} & \multirow{5}{*}{55.6} & \multirow{5}{*}{30} & \multirow{5}{*}{1.7} & \multirow{5}{*}{2} & \multirow{5}{*}{5} & \multirow{5}{*}{116} & \multirow{5}{*}{0.59} & \multirow{5}{*}{332} & & & \\
\hline & 2 & 98 & & & & & & & & & & & & & \\
\hline & 3 & 3 & & & & & & & & & & & 62.8 & 12.4 & 2105 \\
\hline & 4 & 62 & & & & & & & & & & & & & \\
\hline & 5 & 29 & & & & & & & & & & & & & \\
\hline & 6 & 75 & & & & & & & & & & & & & \\
\hline & 7 & 22 & & & & & & & & & & & & & \\
\hline $\mathrm{CH}-2 \mathrm{~b}$ & 8 & 0 & 5.7 & 10.4 & 47.6 & 42 & 1.6 & 1 & 13 & 92 & 0.43 & 196 & 46.6 & 8.9 & 2095 \\
\hline & 9 & 57 & & & & & & & & & & & & & \\
\hline & 10 & 55 & & & & & & & & & & & & & \\
\hline & 1 & 78 & & & & & & & & & & & & & \\
\hline & 2 & 90 & & & & & & & & & & & & & \\
\hline & 3 & 100 & & & & & & & & & & & & & \\
\hline & 4 & 77 & & & & & & & & & & & & & \\
\hline $\mathrm{CH}_{-3}$ & 5 & 100 & 68 & 124 & 596 & 28 & 43 & 17 & 6 & 107 & ר & 155 & 522 & 113 & 1996 \\
\hline לות & 6 & 72 & 0.0 & 12.4 & ל & 20 & $4 . J$ & & & וענו & 0.25 & & 52.2 & ك. & טכנו \\
\hline & 7 & 100 & & & & & & & & & & & & & \\
\hline & 8 & 88 & & & & & & & & & & & & & \\
\hline & 9 & 100 & & & & & & & & & & & & & \\
\hline & 10 & 100 & & & & & & & & & & & & & \\
\hline & 1 & 82 & & & & & & & & & & & & & \\
\hline CHM-? & 2 & 79 & 70 & 244 & 436 & 32 & 2 & 3 & 44 & 126 & 021 & 146 & 248 & 21 & 1202 \\
\hline Cinivi-z & 3 & 96 & 1.0 & 24.4 & & & & & & & 0.21 & & & & 1202 \\
\hline & 4 & 78 & & & & & & & & & & & & & \\
\hline $\mathrm{CH}-4$ & 1 & 0 & 7.0 & 18.4 & 55.6 & 26 & 1.1 & 2 & 8 & 41 & 1.09 & 352 & 47.0 & 8.9 & 1243 \\
\hline $\mathrm{CH}_{-5}$ & 1 & 95 & 58 & 81 & 896 & 2 & 07 & 7 & 12 & 31 & هחת & 325 & 509 & 11 & 1121 \\
\hline Cח-כd & 2 & 96 & 5.8 & 8.4 & 89.6 & 2 & 0.1 & 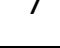 & 13 & 34 & 0.09 & 335 & 50.9 & 1.4 & $14 \angle 4$ \\
\hline
\end{tabular}




\begin{tabular}{|c|c|c|c|c|c|c|c|c|c|c|c|c|c|c|c|}
\hline & 3 & 100 & & & & & & & & & & & & & \\
\hline & 4 & 88 & & & & & & & & & & & & & \\
\hline & 5 & 84 & & & & & & & & & & & & & \\
\hline & 6 & 100 & & & & & & & & & & & & & \\
\hline & 7 & 86 & & & & & & & & & & & & & \\
\hline & 8 & 91 & & & & & & & & & & & & & \\
\hline & 9 & 92 & & & & & & & & & & & & & \\
\hline $\mathrm{CH}-5 \mathrm{~b}$ & 10 & 100 & 7.9 & 8.4 & 77.6 & 14 & 2.2 & 7 & 4 & 45 & 0.28 & 335 & 50.9 & 13.7 & 1424 \\
\hline \multirow{10}{*}{ R9-1 } & 1 & 67 & \multirow{10}{*}{6.9} & \multirow{10}{*}{18.4} & \multirow{10}{*}{57.6} & \multirow{10}{*}{24.0} & \multirow{10}{*}{0.7} & \multirow{10}{*}{1.0} & \multirow{10}{*}{23.0} & \multirow{10}{*}{35.0} & \multirow{10}{*}{0.08} & \multirow{10}{*}{18} & \multirow{10}{*}{35.4} & \multirow{10}{*}{1.5} & \multirow{10}{*}{479} \\
\hline & 2 & 35 & & & & & & & & & & & & & \\
\hline & 3 & 89 & & & & & & & & & & & & & \\
\hline & 4 & 72 & & & & & & & & & & & & & \\
\hline & 5 & 52 & & & & & & & & & & & & & \\
\hline & 6 & 84 & & & & & & & & & & & & & \\
\hline & 7 & 88 & & & & & & & & & & & & & \\
\hline & 8 & 52 & & & & & & & & & & & & & \\
\hline & 9 & 86 & & & & & & & & & & & & & \\
\hline & 10 & 45 & & & & & & & & & & & & & \\
\hline \multirow{10}{*}{ R9-2 } & 1 & 66 & \multirow{10}{*}{6.2} & \multirow{10}{*}{26.4} & \multirow{10}{*}{44.0} & \multirow{10}{*}{30.0} & \multirow{10}{*}{2.1} & \multirow{10}{*}{6.0} & \multirow{10}{*}{7.0} & \multirow{10}{*}{110.0} & \multirow{10}{*}{0.22} & \multirow{10}{*}{230} & & & \\
\hline & 2 & 85 & & & & & & & & & & & & & \\
\hline & 3 & 27 & & & & & & & & & & & & & \\
\hline & 4 & 40 & & & & & & & & & & & & & \\
\hline & 5 & 99 & & & & & & & & & & & 18.9 & 8.8 & 486 \\
\hline & 6 & 85 & & & & & & & & & & & 18.9 & 8.8 & 486 \\
\hline & 7 & 100 & & & & & & & & & & & & & \\
\hline & 8 & 76 & & & & & & & & & & & & & \\
\hline & 9 & 84 & & & & & & & & & & & & & \\
\hline & 10 & 100 & & & & & & & & & & & & & \\
\hline & 1 & 100 & & & & & & & & & & & & & \\
\hline & 2 & 92 & & & & & & & & & & & & & \\
\hline R193 & 3 & 48 & 8.0 & 22.4 & 47.6 & 30.0 & 1.5 & 5.0 & 2.0 & 211.0 & 0.40 & 203 & 42.6 & 26.1 & 577 \\
\hline & 4 & 100 & & & & & & & & & & & & & \\
\hline & 5 & 92 & & & & & & & & & & & & & \\
\hline
\end{tabular}




\begin{tabular}{|c|c|c|c|c|c|c|c|c|c|c|c|c|c|c|c|}
\hline & 6 & 58 & & & & & & & & & & & & & \\
\hline & 7 & 97 & & & & & & & & & & & & & \\
\hline & 8 & 55 & & & & & & & & & & & & & \\
\hline & 9 & 93 & & & & & & & & & & & & & \\
\hline & 10 & 56 & & & & & & & & & & & & & \\
\hline \multirow{10}{*}{ R52 } & 1 & 15 & \multirow{10}{*}{8.0} & \multirow{10}{*}{24.4} & \multirow{10}{*}{41.6} & \multirow{10}{*}{34.0} & \multirow{10}{*}{0.9} & \multirow{10}{*}{1.0} & \multirow{10}{*}{2.0} & \multirow{10}{*}{144.0} & \multirow{10}{*}{0.36} & \multirow{10}{*}{16} & \multirow{10}{*}{25.7} & \multirow{10}{*}{26.2} & \multirow{10}{*}{566} \\
\hline & 2 & 40 & & & & & & & & & & & & & \\
\hline & 3 & 29 & & & & & & & & & & & & & \\
\hline & 4 & 22 & & & & & & & & & & & & & \\
\hline & 5 & 0 & & & & & & & & & & & & & \\
\hline & 6 & 8 & & & & & & & & & & & & & \\
\hline & 7 & 11 & & & & & & & & & & & & & \\
\hline & 8 & 8 & & & & & & & & & & & & & \\
\hline & 9 & 5 & & & & & & & & & & & & & \\
\hline & 10 & 0 & & & & & & & & & & & & & \\
\hline \multirow{10}{*}{164} & 1 & 100 & \multirow{10}{*}{7.1} & \multirow{10}{*}{28.4} & \multirow{10}{*}{53.6} & \multirow{10}{*}{18.0} & \multirow{10}{*}{2.3} & \multirow{10}{*}{5.0} & \multirow{10}{*}{3.0} & \multirow{10}{*}{74.0} & \multirow{10}{*}{0.38} & & & & \\
\hline & 2 & 100 & & & & & & & & & & & & & \\
\hline & 3 & 8 & & & & & & & & & & & & & \\
\hline & 4 & 100 & & & & & & & & & & & & & \\
\hline & 5 & 34 & & & & & & & & & & 138 & 118 & 127 & 576 \\
\hline & 6 & 98 & & & & & & & & & & & & & \\
\hline & 7 & 96 & & & & & & & & & & & & & \\
\hline & 8 & 98 & & & & & & & & & & & & & \\
\hline & 9 & 100 & & & & & & & & & & & & & \\
\hline & 10 & 98 & & & & & & & & & & & & & \\
\hline & 1 & 100 & & & & & & & & & & & & & \\
\hline & 2 & 100 & & & & & & & & & & & & & \\
\hline & 3 & 100 & & & & & & & & & & & & & \\
\hline $164 B$ & 4 & 99 & 74 & 20 & 432 & 36 & 25 & 50 & 70 & 1120 & 021 & 136 & 89 & 94 & 1495 \\
\hline & 5 & 100 & 1.4 & & & & 2.3 & & 1.0 & $1+2.0$ & 0.21 & טכد & 0.5 & 3.4 & נכדו \\
\hline & 6 & 100 & & & & & & & & & & & & & \\
\hline & 7 & 84 & & & & & & & & & & & & & \\
\hline & 8 & 96 & & & & & & & & & & & & & \\
\hline
\end{tabular}




\begin{tabular}{|c|c|c|c|c|c|c|c|c|c|c|c|c|c|c|c|}
\hline & 9 & 100 & & & & & & & & & & & & & \\
\hline & 10 & 100 & & & & & & & & & & & & & \\
\hline \multirow{10}{*}{ EBB } & 1 & 100 & \multirow{10}{*}{5.2} & \multirow{10}{*}{16.0} & \multirow{10}{*}{57.2} & \multirow{10}{*}{26.8} & \multirow{10}{*}{0.8} & \multirow{10}{*}{1.0} & \multirow{10}{*}{18.0} & \multirow{10}{*}{56.0} & \multirow{10}{*}{0.11} & \multirow{10}{*}{200} & \multirow{10}{*}{45.1} & \multirow{10}{*}{4.9} & \multirow{10}{*}{2332} \\
\hline & 2 & 100 & & & & & & & & & & & & & \\
\hline & 3 & 98 & & & & & & & & & & & & & \\
\hline & 4 & 98 & & & & & & & & & & & & & \\
\hline & 5 & 98 & & & & & & & & & & & & & \\
\hline & 6 & 99 & & & & & & & & & & & & & \\
\hline & 7 & 100 & & & & & & & & & & & & & \\
\hline & 8 & 97 & & & & & & & & & & & & & \\
\hline & 9 & 98 & & & & & & & & & & & & & \\
\hline & 10 & 99 & & & & & & & & & & & & & \\
\hline \multirow{10}{*}{ CFE } & 1 & 100 & \multirow{10}{*}{6.0} & \multirow{10}{*}{16.0} & \multirow{10}{*}{61.2} & \multirow{10}{*}{22.8} & \multirow{10}{*}{2.2} & \multirow{10}{*}{1.0} & \multirow{10}{*}{8.0} & \multirow{10}{*}{84.0} & \multirow{10}{*}{0.45} & \multirow{10}{*}{338} & & & \\
\hline & 2 & 88 & & & & & & & & & & & & & \\
\hline & 3 & 100 & & & & & & & & & & & & & \\
\hline & 4 & 94 & & & & & & & & & & & & & \\
\hline & 5 & 100 & & & & & & & & & & & 108 & 148 & \\
\hline & 6 & 98 & & & & & & & & & & & 10.0 & 14.0 & \\
\hline & 7 & 100 & & & & & & & & & & & & & \\
\hline & 8 & 85 & & & & & & & & & & & & & \\
\hline & 9 & 100 & & & & & & & & & & & & & \\
\hline & 10 & 86 & & & & & & & & & & & & & \\
\hline & 1 & 100 & & & & & & & & & & & & & \\
\hline & 2 & 100 & & & & & & & & & & & & & \\
\hline & 3 & 100 & & & & & & & & & & & & & \\
\hline & 4 & 99 & & & & & & & & & & & & & \\
\hline R10 & 5 & 100 & 81 & 68 & (02) & ח & 36 & 40 & 00 & 710 & ת2 & חด & 167 & 130 & 1873 \\
\hline nIf & 6 & 100 & 0.1 & 0.0 & 15.2 & 0.0 & 3.0 & 4.0 & 9.0 & 11.0 & 0.24 & 50 & 10.1 & 13.3 & J 101 \\
\hline & 7 & 99 & & & & & & & & & & & & & \\
\hline & 8 & 100 & & & & & & & & & & & & & \\
\hline & 9 & 100 & & & & & & & & & & & & & \\
\hline & 10 & 100 & & & & & & & & & & & & & \\
\hline
\end{tabular}




\subsection{Appendix D: Field Work Forms}

RP-293 Field Form (1)

Field Site Form

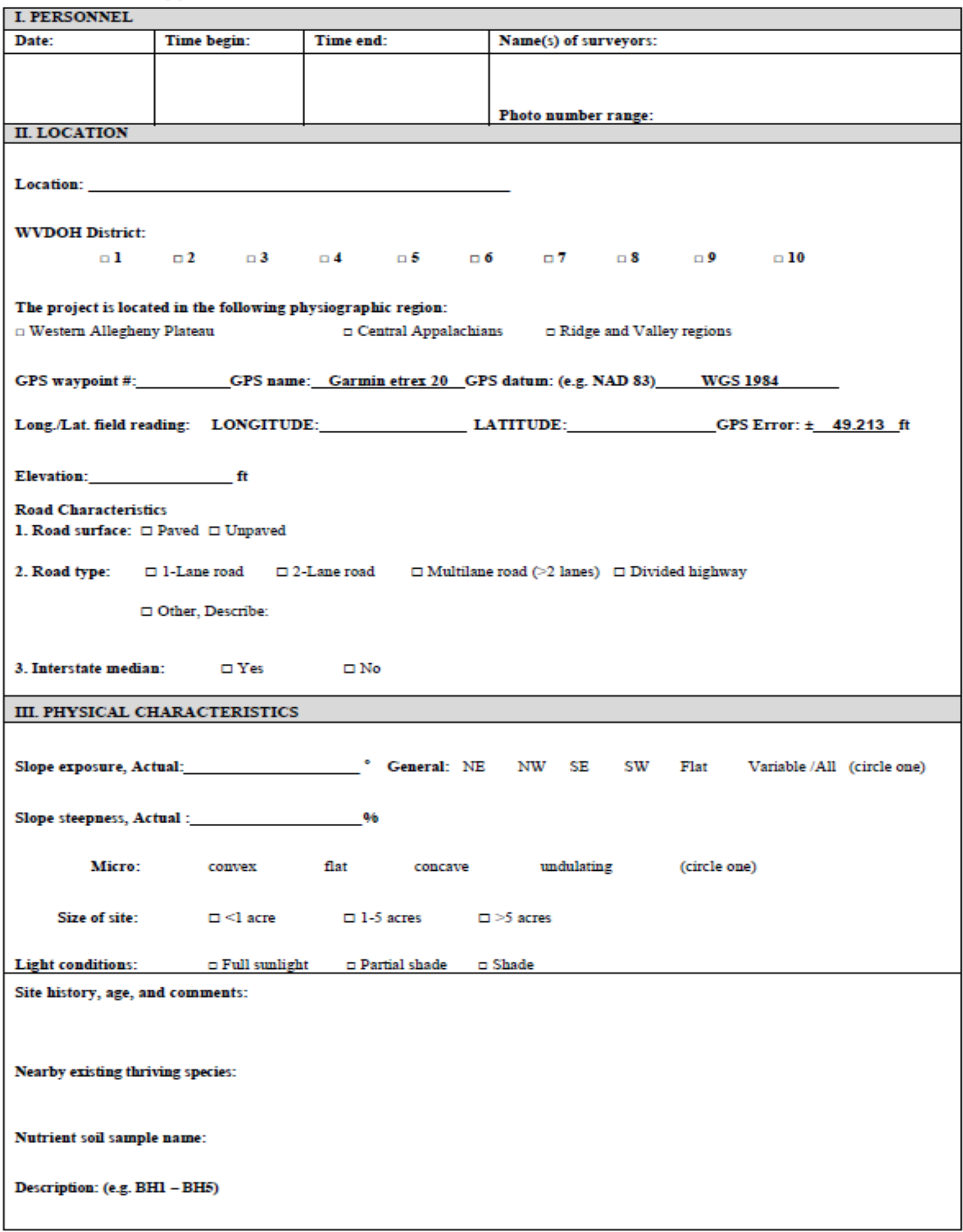

Figure 89: Field site form - general site location (front) 
- Record GPS location of all 4 corners of plot area.

- Draw an " $\mathbf{X}$ " in the approrimate location of each plot, and label each plot accordingly.

- Note distance between plots

Figure 90: Field site form - general site location (back) 


\section{LOCATION}

Location:

Site Name:

GPS waypoint \#:

GPS name: Garmin etrex 20 GPS datum: (e.g. NAD 83)

WGS 1984

Long./Lat. field reading: LONGITUDE:

LATITUDE:

GPS Error: $\pm \underline{49.213 \mathrm{ft}}$

Elevation: $\mathrm{ft}$

Slope exposure, Actual : - General: NE NW SE SW Flat

Variable /All (circle one)

Slope steepness, Actual : 96

II. SOIL

Physical characteristics soil sample name:

Observations:

Stoniness:

Field terture: : $\square$ Sand

\section{VEGETATION}

\begin{tabular}{|c|c|c|c|c|}
\hline \multicolumn{2}{|c|}{ Stem height and diameter (20 random) } \\
\hline & Height & & \\
\hline 1 & & 1 & \\
\hline 2 & & 2 & \\
\hline 3 & & 3 & \\
\hline 4 & & 4 & \\
\hline 5 & & 5 & \\
\hline 6 & & 6 & \\
\hline 7 & & 7 & \\
\hline 8 & & 8 & \\
\hline 9 & & 9 & \\
\hline 10 & & 10 & \\
\hline
\end{tabular}

Figure 91: Field site form - sub-site location (front) 


\begin{tabular}{|c|c|c|c|c|c|c|c|c|c|c|}
\hline & $\mathbf{A}$ & B & C & D & $\mathbf{E}$ & $\mathbf{F}$ & $\mathbf{G}$ & $\mathrm{H}$ & I & $\mathbf{J}$ \\
\hline 1 & & & & & & & & & & \\
\hline 2 & & & & & & & & & & \\
\hline 3 & & & & & & & & & & \\
\hline 4 & & & & & & & & & & \\
\hline 5 & & & & & & & & & & \\
\hline 6 & & & & & & & & & & \\
\hline 7 & & & & & & & & & & \\
\hline 8 & & & & & & & & & & \\
\hline 9 & & & & & & & & & & \\
\hline 10 & & & & & & & & & & \\
\hline
\end{tabular}

Note: If intersection bas cover, mark with a " $\mathrm{C}$ ". If no cover, mark with a " $\mathrm{B}$ ".

Number of Cover: 90

Number of Bare: $\%$

Percent Cover Photo Name and Number:

Description:

Compaction Test Form

Tip Size Used:

3" Color:

Range:

6" Color:

Range:

9" Color:

Range:

12" Color: Range:

15" Color: Range:

18" Color: Range:

Observations:

Figure 92: Field site form - sub-site location (back) 


\begin{tabular}{|c|c|c|}
\hline I. Photo Log & & \\
\hline Location: & & \\
\hline Site \# & Photo \# & Description \\
\hline & & \\
\hline & & \\
\hline & & \\
\hline & & \\
\hline & & \\
\hline & & \\
\hline & & \\
\hline & & \\
\hline & & \\
\hline & & \\
\hline & & \\
\hline & & \\
\hline & & \\
\hline & & \\
\hline & & \\
\hline & & \\
\hline & & \\
\hline & & \\
\hline & & \\
\hline & & \\
\hline
\end{tabular}

Figure 93: Field site form - sub-site photo form 